



\section{ZOOLOGISCHE JAHRBÜCHER}

HERAUSGEGEBEN

VON

PROF. DR. J. W. SPENGEL

SUPPLEMENT XIV. ZWEITES HEFT

\section{COXAL GLANDS OF THE ARACHNIDS \\ $\mathrm{BI}$}

B. H. BUXTON

WITH 43 PLATES, A FRONTISPICE AND 7 FIGURES IN THE TEXT
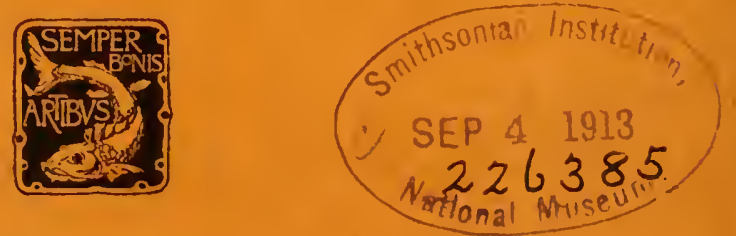

JEN A

VERLAG VON GUSTAV FISCHER

1913 


\title{
Zoologische Jahrbiicher.
}

\author{
Herausgegeben von Prof. Dr. J. W. Spengel in Gießen.
}

\section{Supplemente:}

(1)

(2)

(3)

Die Schmetterlingsfanma Nordwest-Dentschiands, insbesondere die lepidopterolog. Verhältuisse der Umgebung von Güttingen. Von Dr. Karl Jordan. 1886.

Preis: 5 Mark.

Die Fauna von Helgoland. Ton Dr. K. W. v. Dalla Torre, Prof. an der Universität Inusbruck. 1889.

Preis: 2 Mark 40 Pf.

Studii sui Trematodi eudoparassiti. Primo contributo di osservazioni sui Distomidi. Von Fr. Sav. Monticelli, a. o. Prof. in Sassari. Con 8 tavole litogr. e 3 fig. nel testo. $1893 . \quad$ Preis: 15 Mark.

Fauna Chilensis aliaruncue regioun neotropicarum. Abhaudlungen zur Kenntnis der Zoologie Chiles und anderer neotropischer Gebiete nach den Sammlungen von Prof. Dr. L. Plate.

1. Band. Drei Ifefte. Mit 36 Tafeln und 3 Abbild. im Text. 1897-1899. (Heft 1: $25 \mathrm{Mk}$. - Heft 2: $20 \mathrm{Mk}$. - Heft 3: $20 \mathrm{Mk}$. )

Preis: 65 Mark.

II. Band. Drei Hefte. Mit 23 Tafeln und 3 Abbild. im Text. 1899-1902.

(Heft 1: $20 \mathrm{Mk}$ - - Heft 2: $20 \mathrm{Mk}$. - Heft 3:12 Mr. $50 \mathrm{Pf}$.

III. Band. Drei Hefte. Mit 44 Tafeln, 1 Karte und 170 Abbildungen im Text. 1903-1904.

(Heft 1: $20 \mathrm{Mk}$. - Heft 2: $20 \mathrm{Mk}$. - Heft 3: $30 \mathrm{Mk}$.)

IV. Band. Heft 1-3. Mit 21 Tafeln und 107 Abbildungen im Text. 1911 bis 1913 .

(Heft 1: $20 \mathrm{Mk}$. - Heft 2: 15 Mk. - Heft 3:16 Mk.)

Inhaltsverzeichnis kostenfrei.

Festschrift anm 70. Geburtstage des Herrn Gel. Rats Prof:

Dr. A. Weismanu. Mit 32 Tafeln und 104 Textabbildungen. 1904.

Preis: 60 Mark.

Inbalt: Ueber das Vorkommen eines Kehlkoples bel Ganolden and Dipnoern sowie über die Phylogenle der Lnuge. Von $R$. W iedersheim. Mit 6 Tafeln und 1 Abbildung im Text. [9 M.] - Uober Amoeba viridis Leidy. Von A ugust Gruber. Mit 1 Tafel. [2 M. 50 Pf.] Künstliche Partbenogeneso. Von Alexander Petrunkewitsch. Mit 3 Tafeln und 8 Abbil. dungeu im Text. [5 M.] - Keimfleck and Synapis. Von Konrad Guenther. Mit 2 Tafel. [2 M.] - Bastardierumg and Gescblechtszollenblldung. Von Valentin Häeker. Mit 1 Tafel und 23 Abbildungen im Text. [4 M.] - Dober Doppelbildungen bei Lumbricidon. Von E. Korschelt. Mit 2 Tafeln und 7 Abbildungen im Text. [2 M.] - Antbraconema. Von Otto L. zur Strassen. Mit 2 Tafeln und 9 Abbildungen im Text. [4 M.] - Ueber die Entwickinng der Vollola ans einer in der Tlefo vorkommenden Larve. Von R. Woltereck. Mit 3 Tafeln und 6 Abbildungen im Text. [5 M.] - Dio Hemipterengattung Polyctenes Gigl. und inro Stellung im System. Vou P. Speiser. Mit I Tafel. [1 M.] - Beiträge zar Kenatnis der Entwicklung nud Anatomie der Gymophionen. Von August Brauer. Mit 3 Tafeln und 7 Abbildungen im Text. [3 M.] Ueber die phylogenetische Bedeutang der Sehorgano des Amphioxns. Von Th. B overi. Mit 10 Abbildungen im Text. [2 M.] - Ueber experimentell erzengte Doppeiblidangen mitzy klopisobem Delekt. Von Hans Spemann. Mit 2 Tafeln und 24 Abbildungen im Text. [3 M.] - Ueber den feinern Ban der Stäbohon and Zapfen einiger Wirbeltiere. Mit 1 Tafel und 3 Abbildungen im Text. [2 M. 50 Pf.] - Deber die Entwicklung von Gyrodaotylus elegans v. Nordm. Von L. Kathariner. Mit 3 Tafeln und 10 Abbildungen im Text. [3 M. 50 Pf.] - Veber die Bnmmeln als Zengen natürliober Formenbildung. Von H. Friese u. F. v. Wagner. Mit 2 Tafeln. [5 M.] - Uober Polymorphismas and Variation bel den Ameisen. Von A ugust Forel. [1 M. $]$ - Zur Kenutuis des Polymorphismus der Amoisen. Von C. Emery. Nit 6 Abbildungen im Text. [1 M. 50 Pf.] Zur Kenntuis der Gäste der Treiberameisen und ihrer Wirte vom oberen Kongo. Von E. Wasmann. Mit 3 Tafeln. [5 M.] - Brutplege bel Eobinodermen. Von H u bert L udwig. [80 Pf.] - Der Begrifi des Instinkts elast nud jetzt. Von Heiurich Erust Ziegler. (2. Auflage 1910.) [3 M.] - Veber Soluwimmblasen, Lungen nad Kiementasoben der Wirbeltiere. Von J. W. Spengel. [1 M. 20 Pf.] 


\title{
ZOOLOGISCHE JAHRBÜCHER
}

\author{
HERAUSGEGEBEN
}

VOx

\section{PROF. DR. J. W. SPENGEL

\section{SUPPLEMENT XIV.}

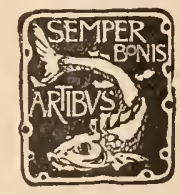

JENA

VERLAG VON GUSTAY FISCHER

1913

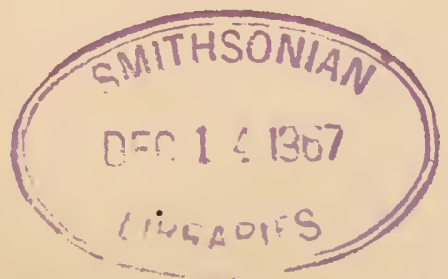


Alle Rechte, uamentlich das der Übersetzung, vorbehalten.

$$
A=233156 \mathrm{Kew}=\mathrm{d}
$$




\section{$6346-9$}

\section{Inhalt.}

\section{Erstes Heft.}

(Ausgegeben am 23. Februar 1912.)

Oudemans, A. C., Die bis jetzt bekannten Larven von Thrombidiidae und Erythraeidae. Mit 57 Abbildnngen im Text . . . 1

\section{Zweites Heft.}

(Ausgegebell am 23. Juli 1913.)

Buxtox, B. H., Coxal glands of the Arachnids. With Plates $1-43$,

a Frontispice and 7 Figures in the text...... . $\left.L_{2} 3\right]_{7}$ 




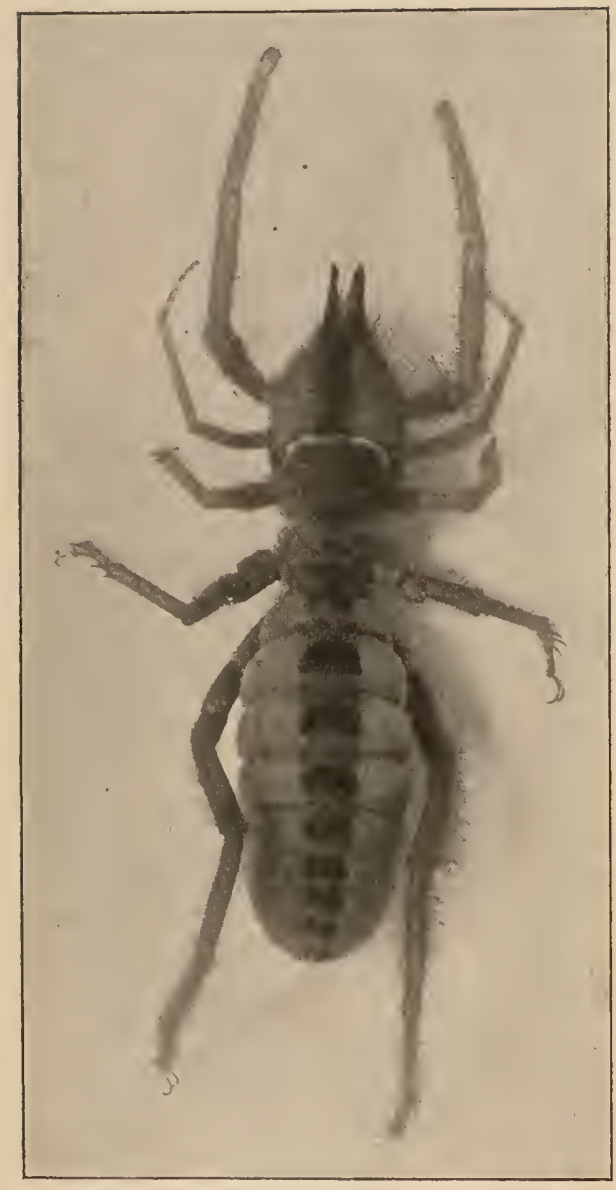

A

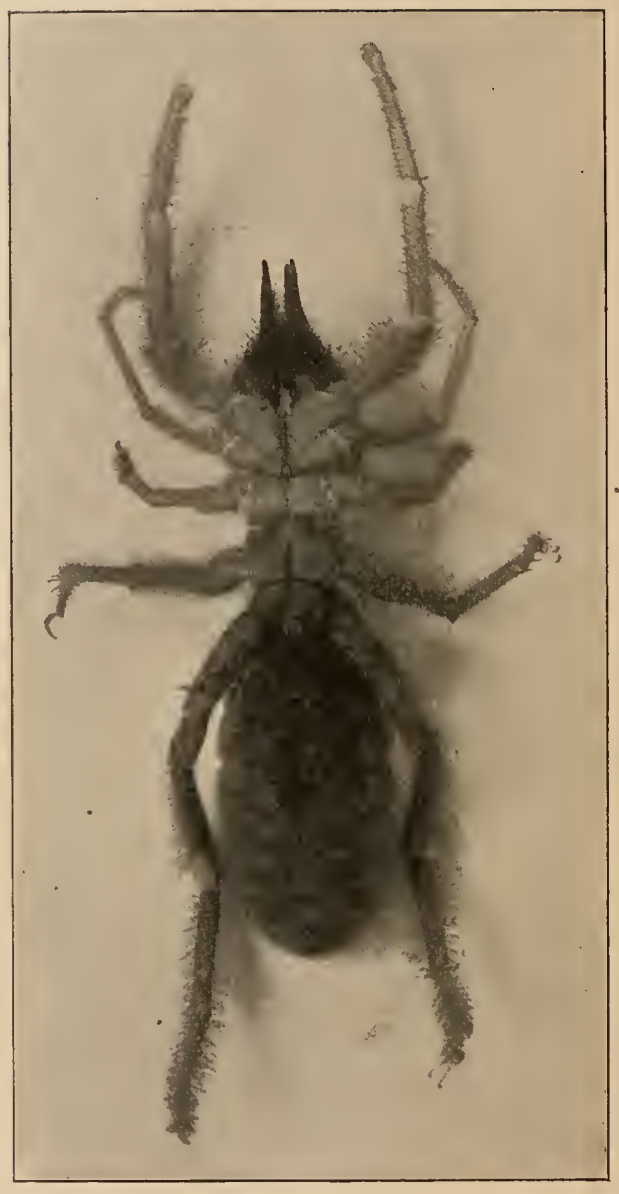

B

Paragaleodes sp.? 


\section{Coxal glands of the Arachnids.}

\section{By}

B. H. Buxton.

(Cornell medical college, New York.)

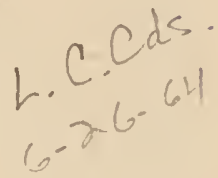

lates $1-43$ and 7 Figares in the text.

\section{Part I. Pulmonate Arachnids.}

\section{Introduction.}

Limulus has probably in many respects the most primitive arrangement of the coxal glands among the arachnids. According to Patter each gland consists of four lobes (saccules), one at the base of each appendage two to five. A short duct comnects each lobe with the common duct (labyrinth), which after a series of complicated twists and turns, finally ends in a straight dilated exit tubule or end sac with its outlet just posterior to the base of the coxal joint of the fifth appendage. In the embryo, lobes are also formed on the first and sixth appendages, but degenerate and disappear in the course of development.

The arachnids studied for the purpose of this article were the Scorpions, Pedipalps, Spiders, Solifugae and more superficially the Phalangids. In the coxal glands of each of these orders the same fundamental arrangement as in Limulus can be traced, although the number of the lobes, or saccules, to adopt Bruxtz's nomenclature, 
has been reduced to a single one in each case, with the exception of the primitive Theraphosid spiders which have two saccules still remaining, one on the third and the other on the fifth appendage. The coxal glands of the Theraphosids have also two outlets corresponding to the position of the two saccules, i. e. on the third and fifth appendages, but all the other arachnids have but a single outlet.

In the scorpions and phalangids the outlet is at the base of the fifth appendage, corresponding in position to that of Limulus. In the true spiders (Araneae verae) and the Pedipalps the outlet is on the third appendage and in the Solifugae on the second appendage. My endeavor will be to demonstrate by means of description and photographs that these conceptions of the arachnid coxal gland are correct, and also to point out the various modifications which the structure has undergone in the course of specialisation.

Almost all of the animals studied were collected by myself, killed with chloroform, and immediately fixed in Duboscre's picroformal-acetic solution. Before fixation, the legs and abdomen were cut off so as to allow of penetration of the fixing fluid into the cephalothorax. Imbedding first in celloidin and then in paraffin was found to be the best method for obtaining good serial sections, as in this way the use of xylol is avoided and the chitin, always a difficulty, does not become so brittle. Moreover, when the more delicate tissnes are padded with celloidin they do not become distorted in the hot paraffin.

For identification of the species I am indebted to Dr. ALEx. Petrunkevitch of Yale University to whom my best thanks are due. A few specimens preserved in the ordinary way in alcohol were also kindly provided by the late Prof. T. H. Montgomery, Prof. Alex. Petrunkevitch and M. Eugene Simon of Paris, but naturally sections from alcohol specimens are not often sufficiently well preserved for photography or for study of finer details. Where such specimens are referred to they are indicated as such by (alc. spec.) in brackets and the initial of the donor M., P., or S. The photographs were all taken direct from the sections and have not been retouched.

Before beginning an account of the special work done, it may be well to explain in a general way the characteristics of the organs 
and their. cells; the constituent parts in their order from the terminal part to the exterior being designated as the saccule $(S)$, the collecting tubule $(C T)$, the labyrinth $(C L)$, the bladder or vesicle $(V)$ and the exit tubule $(E T)$ leading to the outlet $(O)$.

The typical cells of the labyrinth coils have a striated base in which the cell outline is lost, so that the striated layer of the cells appears continuous (photo $\check{5} \mathrm{~b}$ ). Directly upon the striated layer or immediately beneath its border, but never at its base, lie the nuclei, generally very large and prominent with much chromatin (photo 1), but the variations are considerable; the cell nuclei of some scorpions, and more particularly of the solifugae being extraordinarily minute (photo 1 a).

That part of the cell cytoplasm lying above the striated border may be extensive, forming large well defined columnar or cubical cells (photo 10), or the cell surface may be greatly worn down so that the nuclei may appear to lie upon the striated border with only fragments of cytoplasm attached to them (photos 15 a $C L$ and 22).

The typical saccule which is commonly held to represent the last remnants of the coelom, does not form definite coiled tubules like the labyrinth, but is actually of the nature of a sac, indented in every direction by blood capillaries, which penetrate into the sac and hang in it; the very thin walls of the sac being lined internally with a delicate epithelium which may be flattened so as to resemble an endothelinm. The capillaries therefore would seem to serve the same purpose as the glomeruli of the vertebrate kidney and may be referred to as glomeruli (photo 30 GLR). The capillaries however can hardly, strictly speaking, be considered as such. They are simply lacunae of the hemolymph system withont any walls of their own, so that nothing lies between the body fluid and the lumen of the saccule, except the thin wall of the saccule itself with its lining epithelium.

At a certain point in the saccule the lumen, freeing itself from the inhanging capillaries, becomes dilated, forming a central lumen (CSL) and from this central lumen of the saccule there runs a short duct, or collecting tubule $(C T)$ lined with epithelium (photo $9 \mathrm{~b}$ ) which then passes into the labyrinth $(C L)$; the change from the epithelinm of the dnct to the striated epithelium of the labyrintl being very abrupt.

The exit tubnle is very narrow, lined with chitin and evidently formed by an involution of the external surface, the cells beneath 
the chitin resembling those of the hypodermis. The arrangement of muscles around the exit tubule seems to indicate that the outlet can be closed and opened at will. Just before reaching the exit tubule, the labyrinth tubule straightens ont and sometimes becomes dilated, forming a vesicle or bladder (PatTen's "end-sac" in Limulus).

\section{Scorpions.}

The coxal glands of the scorpions were first described by LANKESTER who recognized the tubules lined with striated epithelium (the labyrinth), and a medullary portion, enclosed by the tubules.

The medullary portion was first recognized by MaRchaL (1892) as the saccule, from which the collecting tubule passes into the labyrinth. Marchal speaks of the lacunae of the saccule and the lacunae of the hemolymph system, which together form the medullary portion, but the saccule possesses definite walls lined with epithelium, so it would hardly seem correct to describe its lumina as lacunae.

Marchal also drew attention to the homology between the coxal glands of the scorpion, and the green glands of the decapods, which also have a saccule and a labyrinth distinct from each other.

The coxal gland of the scorpion is very compact, situated opposite the bases of the fifth and sixth appendages; its posterior border lying on the anterior surface of the diaphragm $(D)$ which separates the cephalothorax from the abdomen (photo 1,3). The Saccule $(S)$ is surrounded and enclosed by the coils of the labyrinth tubules $(C L)$ except at one point where the blood supply enters the organ. Opposite the entrance of the coxal artery the central lumen of the saccule passes into a short, ill defined collecting tubule, connecting with the labyrinth (Photos 1, $1 \mathrm{a}$, for a general view, and $1 \mathrm{~b}, 1 \mathrm{c}$, for the details of the changes).

The tubules of the labyrinth form complicated coils and finally end in a straight somewhat dilated tubule, which may be regarded as the bladder. The bladder passes into a very narrow straight exit tubule ( $E T$, photo 2) lined with chitin, and obviously derived from the external surface. The outlet appears to be functional even in the adult in spite of much that has been written to the contrary.

Diagram B1 indicates roughly the position of the coxal gland in cephalothorax and the plan on which it is constructed.

At the base of the sixth appendage there is a distinct dip of the labyrinth tubule toward the surface, which in the embryo scorpion 
is very nearly reached (photo 3), although in no specimen has an actual outlet been observed, but the dip may be an indication that there was primarily an outlet at this point as well as the persisting outlet on the fifth appendage. From the disposition of the coxal gland, opposite the bases of both the fifth and sixth appendages, it seems quite possible that it has been formed from a coalescence of the originally distinct organs of the two appendages.

Brauer (1894) in embryo scorpions observed the development of nephridial "Anlagen" on segments two to eight. Those on segments five and eight persist and form the coxal gland and genital system respectively, but the other's degenerate and soon disappear. He says nothing however, about a coalescence of the glands on the fifth and sixth segments but remarks that the nephridium of the sixth segment is the last of the transient ones to disappear.

The source of the blood supply for the saccule is interesting; somewhat different from that found in other arachnids, and so far as I can gather, has not hitherto been described. Accompanying. the nerve from the brain mass to each of the appendages is an artery; a well defined thick walled vessel. The artery which accompanies the nerve of the fifth appendage $(N V)$, on reaching the base of the appendage, sends off a branch $(C A)$ at right angles to its course direct to the saccule of the coxal gland (photo 4 . The course of the artery can also be traced intermittently in plotos 1 , and $1 \mathrm{a}$ ). On reaching the coxal gland at the point where the saccule comes nearly to the surface of the gland, the artery breaks up, and the fluid, passing through a mass of cellular lymphoid tissue which may be referred to as the glomus ( $G L$ photos $\tilde{5}, 5$ a), forms numerous capillaries, or rather lacunae, which hang into the lumen of the saccule; forming glomeruli in the typical manner already described in the introduction.

So far the description of the coxal gland may be applied to all scorpions but we now come to an accessory organ which is not found in all of the families.

Kowalevsky first described this organ in Buthus occitanus from the South of France, but remarks that he conld not find it in Androctonus, an allied Buthid from Russia. Androctonus is simply a synonym for Buthus and his species was probably $B$. cancasicus. He called it the lymphatic organ to distinguish it from the lymphoid organ which lies above the nerve cord along its whole length in the abdomen of all scorpions. According to Kowalevsiy the lym- 
phatic organ is a diverticulum from the diaphragm which becomes filled with cells but remains open opposite the coxal glands.

It is obvious that the blood supply to the saccule of the coxal gland must be very limited; merely a branch of a single artery, and the lymphatic organ of Kowalevsky appears to have been evolved as a means of bringing waste products directly from the abdomen to the coxal glands. It is probably a recent addition to the execretory system, as there is nothing analogous to it to be found in any of the other arachnids, nor is it present in all scorpions. The organ itself $(L O)$ forms a kind of sac with a thick hyaline wall lying in the abdomen, its interior being occupied by small lymphoid cells, among which are also found the larger phagocytic connective tissue cells, often containing granules; the nephrocytes of Bruntz. ${ }^{1}$ ) Anteriorly there is an orifice which opens through the diaphragm into the capsule of the coxal gland, but it has no direct connection with the saccule (photos $6,6 \mathrm{a}, 6 \mathrm{~b}, 6 \mathrm{c}$, at $L O$ ).

The walls of the lymphatic organ are certainly not muscular, nor are any muscles attached to them, so there would not appear to be any pumping action; the fluid either filtering in, or perhaps excretory products being brought in by the large phagocytes of the comnective tissue, where they are worked over by the lymphocytes and passed on to the coxal gland.

Just ventral to the lymphatic organ and running parallel with it is a large blood sinus (VS) from which, no doubt, the lymphatic organ is supplied with waste products (photo 6).

Of the scorpions, I have examined representatives of four out of the six recognized families.

\section{Fam. Buthidae.}

\section{Subfam. Buthinae.}

Buthus australis, Buthus occitanus

Biskra.

Banyuls, South France. All ages from the advanced egg; just born; one year old up to adult.

1) These cells help to eliminate carmine or other foreign substances injected and therefore act as nephrocytes, but it can be shown by differential staining that they also carry nutrient material from the intestinal coeca, where it is stored up, to the various organs. 
Subfam. Centrurinae.

$\begin{array}{ll}\text { Centrums (?sp.), } & \text { Arizona. } \\ \text { Tityus, } & \text { Panama. } \\ \text { Centrums margaritatus, } & \text { Jamaica and Mexico (alc. sp. P). }\end{array}$

Scorpio maurus,

Diplocentrus scaber, Opisthacanthus elatus,

\section{Euscorpius italicus,}

Chactas (sp. ?),

Vejovis flavies,
2. Fam. Scorpionidae. Biskra, Algeria. Jamaica. Panama.

\section{Fam. Chactidae.}

Lugano, Italy. Colombia.

\section{Fam. Vejovidae.}

\section{Arizona.}

The lymphatic organ is present and readily found in every specimen from the families Scorpionidae, Chactidae and Tejovidae, but no trace of it has been found in any one of the Buthid specimens from the egg up to the adult. This fact, I think, tends to support the hypothesis that it is a recently acquired organ, since if it had been ancestral and discarded by the Buthids, there surely would have been some evidence of it in the earlier stages of development. If the organ can be regarded as a diverticulum or hernia from the diaphragm, as suggested by KowaLEvsKY, its origin can be accounted for in a very simple way.

There appears to be some contradiction here with Kowalersir's findings, since he describes the organ as occurring in Buthus occitanus, but he himself says that he could not find it in the very closely allied Buthid Androctonus, and it seems probable that the specimens sent to him from the South of France were not Buthus, but the equally common Euscorpins flavicanda (Chactid).

\section{Pedipalps.}

The conclusions here arrived at with regard to the coxal glands of the pedipalps are based upon a study of 7 specimens of Tarcuntula palmata from Colombia, and 4 of Tarantula fuscimana from Panama and Costa Rica. The coxal glands of these two closely allied species of the Tarantulidae (Phrynidae) are precisely alike in every particular 
so that a description of one serves equally well for the other species.

I have not been able to examine examples of the Thelyphonidae with the exception of a single specimen of Mastigoproctus giganteus (alc. sp. P.) which was in such a bad state of preservation that little could be made out of its details but so far as could be judged, its coxal glands do not differ in general arrangement from those of Tarantula.

LAURIE found an outlet on the third appendage in Thelyphonus and Bönser remarks that in the pedipalps the coxal gland is extensive with an ontlet on the third appendage; well marked in Thelyphonus but not so clear in the Tarantulidae.

The chief works on the development of the Pedipalps are those of Sophie Pereyescavzewa (1901), Gough (1905) and Schinkevitch (1906). The two former observed in early stages the rudiment of a second gland with indications of a lost outlet on the fourth appendage, but the rudiment soon disappears and in the young pedipalp is no longer traceable.

Börner (1906), in: Zoologica, describes the coxal glands of the pedipalps at some length, but makes no mention of the saccule or collecting tubule, and I cannot find in the literature that they have been observed by any one who has recognised them as a part of the glandular structure, although Pereyesuavzewa figures the saccule in the embryo very clearly, bnt, mistaking its significance, calls it an "agglomeration of connective tissue", forming tubules which will give rise to additional coxal tubules. There is no evidence in her description or figures that she found the collecting tubule, and since the labyrinth consists of a single coiled tube it seems unlikely that new tubules can be formed and added to it.

Sснгмкеviтсн finds in the young larva a communication with the coelom, but in older stages the communication is lost, although he notes the presence of "stroma cells" which he thinks may correspond to the medullary portion of the scorpion's gland, but the stroma cells lie ontside the gland. The "stroma cells" can undonbtedly be referred to the saccule, but he missed the connecting link between it and the labyrinth.

In Tarantula, the coxal glands are not compact as in the scorpion, but elongated, stretching posteriorly from opposite the third appendage to a point between the fifth and sixth appendages; the 
labyrinth tubules comprising by far the largest part of the gland (photos 7, 12).

The outlet is on the posterior aspect of the base of the third appendage (photos 7,8 ) and immediately above the exit tubule (ET) lies the saccule $(S)$ (photos 7,9 ) the details of which present much the same appearance as in the scorpion, with its thin walls lined with delicate epithelium, the inhanging glomernli $(G L R)$ and central lumen of the saccule (CSL) but the saccule in Tarantula is only very partially enclosed by the labyrinth coils. The collecting tubule $(C T)$ which is short, but more clearly defined than in the scorpion, forms the communicating link between the central lumen of the saccule and the labyrinth with its striated cells (photos 9, 9a, 9b, 9c).

The labyrinth $(C L)$ starting from the saccule opposite the third appendage forms coils and twists running posteriorly as far as the posterior aspect of the fifth appendage, where it turns a little ventrally and then runs forward, underneath the coils, as a straight tubule to the exit tubule on the third appendage. It may be referred to as the ventral tubule (VTL) of the labyrinth (photos 7, 7a).

In the coiled part of the labyrinth three divisions may be recognised depending upon the character of the epithelium (photos 7, 12). Roughly speaking the anterior division $(C L a)$ lies mainly opposite the third appendage; the middle division $(C L m)$ opposite the fourth appendage, and the posterior division $(C L p)$ opposite the fifth appendage, but the coils of the three divisions overlap each other and there is no abrupt change from one division to the other, such as is found in the change from collecting tubule to labyrinth.

The cells of the labyrinth throughout show the striated base, but in the middle division the striated base is surmounted by well defined large colmmnar cells with slightly basophil cytoplasm, the nuclei lying at the base of the column, immediately upon the striated base (photo 10).

In the anterior division the nuclei lie, almost bare of cytoplasm, along the free border of the striated portion of the cell, while in the posterior division the cells are for the most part fairly clearly defined and cubical, although in this division there is a good deal of variation and in some places the cytoplasm appears almost worn down to the nuclei. These differences in the three divisions appear to be constant; the middle division with its large basophil cells 
being always clearly marked off between the other two in both species examined.

BörNer figures these cylindrical basophil cells and remarks that they are different from the cells of the coxal glands in Thelyphonus; and also from those of the palpigrades (Koenenia). He does not however appear to have noticed that these cylindrical cells are confined to one part of the labyrinth but speaks as if they were the only kind of excretory cells found in the coxal gland.

With regard to the blood supply, there runs parallel with the labyrinth a large blood sinus (VS) lying ventral to the labyrinth coils (photos 12,12a) alongside of and just internal to the ventral tubule of the labyrinth. From the sinus small branches run in among the coils of the labyrinth so that the tubules are all bathed in the circulating fluid (photo 11). The sinus runs along the whole length of the labyrinth and on reaching the saccule anteriorly, breaks up to form the glomeruli which hang into the saccule. Photograph 11 shows the relation of the ventral sinus to the labyrinth tubule in transverse section.

\section{Spiders.}

Among the spiders there is great variation in the appearance of the coxal glands. It has already been remarked that in the Theraphosids there are two saccules and two different ontlets, but only one of each in the Araneae verae. 'The labyrinth of the Theraphosids is very complicated but in the higher spiders becomes more and more simplified as we pass from the Theraphosids to the Dysderids and Sicariids, and from these through the hunting spiders, Lycosids and Thomisids, to the highest of the web spinners like the Epeirids and Theridiids, in which the labyrinth has become reduced to such an extent that it is no longer recognizable as such. The reduced condition of the coxal glands in the higher spiders has been observed by BertKau and Sturanr, and referred by them to degeneration, but it seems more probable that it is a case of simplification with increased efficiency of the remainder, since the saccule on which may be, the most important part of the work falls, is still in good working order. The writers do not mention the saccule and probably overlooked it. Even Bruntz, who is generally very particular about the saccule, does not seem to recognise it in the higher spiders, and in speaking of elimination of carmine by them, mentions only the nephrocytes (amoeboid connective tissue cells) and the malpighian tubules. BERNARD (1897) suggests that 
in the higher spiders the excretory products are utilized for silk production, and the coxal glands therefore degenerate. The suggestion is a good one so far as excretion by the labyrintl is concerned, but in all spiders excretion by the saccule seems as if it should go on as usual, so far as one can judge by its histological appearance. Both Kowalevsky and Beustz have demonstrated that in scorpions and certain other Arthropods, some (colored) substances injected are eliminated by the saccule and others by the labyrinth, but neither of them appear to have recognised any excretion (of color) by the spinning glands after injection into spiders. But the actual number of spiders so treated up to the present time is very limited.

A. Theraphosids. Specimens sectioned and studied.

\section{Genus ?}

,

Avicularia

Eurypelma vagans and rusticum

Dugesiella hentzii

Hapalopus pentaloris,

Ischnothele

Neocteniza mexicana

Ischnocolus

Atypus affinis
Biskra. Immature.

So. America. Adults and young just leaving cocoon.

Panama. Adults and young with mother and from cocoon.

Texas. (Petrunkevitch. Fixed in sublimate.)

Colombia. Immature.

Colombia. Immature.

Panama.

Arizona.

Europe (alc. spec. S.).

The coxal gland is elongated as in the Pedipalps; the coils of the labyrinth extending forward to the base of the second appendage, and posteriorly almost to the posterior aspect of the sixth appendage. The organ runs continuonsly throughout, just above and external to the endosternite on either side. The labyrinth is so complicated that it has not been possible to follow up the tubules and determine if there are two distinct systems of labyrintls. one for each saccule and outlet, but I am inclined to think not, and to consider the labyrintl as a system of tubules common to the two saccules and outlets.

The two saccules however are clearly distinct as can be best determined by dorso-ventral (frontal) sections. In such sections. tracing from the dorsum downwards, at about the middle of the cephalothorax the labyrinth $(C L)$ can be seen extending continu- 
ously along its length from the third to the sixth appendage inclusive (photo 13), but no saccule is yet visible. On passing to sections more and more ventral the labyrinth breaks up into four parts, one of which is opposite the posterior aspect of each of the appendages from the third to the sixth; showing therefore, that there are four distinct dips of the labyrintl toward the ventral surface (photo 13 a). The two succules on the third and fifth appendages respectively now make their appearance, lying a little external to the labyrinth tubules, but they are quite distinct from each other. I have been unable to trace any saccule on the dip of the sixth appendage, although there is some evidence of a saccule on the fourth appendage, but no collecting tubule or change to labyrinth in connection with it. It appears to be rather an outlying part of the saccule of the third appendage, and not to have an independent existence.

Examining sections still more ventral it is found that the dips of the labyrinth tubules on the fourth and sixth appendages end blindly not far from the ventral surface, while those on the third and fifth pass on to their respective exit tubules and outlets, both of which are functional in the adult as well as in the young. These four dips with the two saccules and two exits can also be readily traced in sagittal and transverse sections.

The dips of the labyrinth on the fourth and sixth appendages seem to indicate that primarily there were outlets at these points also. The dip on the posterior aspect of the sixth appendage in particular shows in the young Avicularia from the cocoon, a very marked string of labyrinth cells (the lumina of the tubules in these specimens are barely apparent) extending right up to the external surface (photo 14).

This extension is so clearly defined that for some time I thought that there must be an outlet there also, but careful search throngh all the specimens has failed to show any.

The saccules (S), as can be seen from the photographs $(15,15$ a, $15 \mathrm{~b}$, on third, and $16,16 \mathrm{a}, 16 \mathrm{~b}$, on fifth appendages) present the typical appearance as described for the scorpions and pedipalps with the inhanging glomeruli (GLR) and the collecting tubule (CT), passing abruptly into the labyrinth $(C L)$. In the labyrinth the cells have the usual striated base upon which rest enormous deeply stained nuclei; the cytoplasm in places being worn down to the nuclei and in other places forming large well outlined cubical cells. 
The exit tubules (ET) on the third appendage can be seen in photographs 15, 15a, 17, 17a, and on the fifth appendage in 18 to $18 \mathrm{c}$. It has not been found possible to get sections on the fifth appendage showing the saccule, collecting tubule and exit tubule all in one field as is seen so clearly in 15 and 15 a for the third appendage.

In Atypus, the two saccules and two ontlets are present, but the labyrinth appears to be less coiled than in the Theraphosids proper. There is already a tendency toward simplification, but the coxal glands of Atypus approach much more closely to the Theraphosid character than to that of the Araneae verae. The finer details, however, could not be determined as I only had at my disposal alcohol specimens kindly provided by MI. Eugìne Sinox.

It may be remarked that the aberrant Ischnothele, which, unlike the other members of the Theraphosid group, have become web spinners, have lost the saccule and ontlet of the fifth appendage, retaining only those of the third appendage. The labyrinth also is greatly reduced and simplified, so that the characters of the coxal glands in this aberrant genus resemble rather those of the Dysderids than of the Theraphosids in general. In the photograph (19) from Ischnothele, the labyrinth tubule leading from the saccule is seen to run posteriorly as a single elongated tubule without coiling, but the walls are irregular in outline, indicating the probability that the straightening out has been caused by the breaking through of adjacent coiled tubules. There is evidence also in the other Theraphosids of this breaking through with consequent fusion of adjacent coils, but it is only in Ischnothele that the process of straightening out has gone far enough to enable one to follow up the course of the tubule.

It is probable that but few well fixed specimens of the 'Theraphosid spiders have been available for study, and there is some apparent discrepancy in the reported observations. Berthau (1885) in Atypus found an outlet on the fifth appendage, and Sturaxx (1891) confirmed this observation, but could find no outlet in a single alcohol specimen of Mygale, and Perseneer (1885) had also previously come to the conclission that in a large Theraphosid examined by him there is no efferent duct either to the exterior or to any intermal organ.

Schrikevitch (1911) has recently studied the development of a Theraphosid (Ischnocolus) from Java, and in the embryo found an 
outlet on the third appendage, but denies the existence of one on the fifth, although the cells dip down very close to the surface. Schminevitch figures sagittal sections in which I have generally found that the outlet on the third appendage is clearly defined, but to observe the whole exit tubule and ontlet of the fifth appendage in one field, it is necessary to have transverse sections. In sagittal sections the course of the exit tubule on the fifth appendage must usually be followed up from section to section and it is often difficult to determine if there is actually an outlet or not. Photograph $18 \mathrm{~b}$ is taken from the only sagittal section I have which shows the exit tubule of appendage $V$ in its entirety. It may be observed that $18,18 \mathrm{a}, 18 \mathrm{c}$ are all taken from transverse sections.

Schinkevitch does not mention the saccule, and his specimens were perhaps too young to show it clearly. I have myself been mable to identify the saccules with certainty in specimens of Avicularia from the cocoon, although in those of Eurypelma (photo 15) at about the same stage of development it is already clearly defined.

Bruntz (1904), so far as I can gather, is the only author who mentions the existence of a saccule. He found it in Atypus and demonstrated that the cells of the saccule eliminate carmine, but not those of the labyrinth. Bruntz was unable to obtain specimens of the Theraphosids, but in a living Dugesiella hentzii from Texas (given to me by Dr. Petrunkevitch) inoculated with carmine and killed three days later, the same results were noted as by Bruntz for Atypus, namely that the cells of the saccule took up carmine, but not those of the labyrinth (photo 20). Both of the saccules were alike in this respect.

The fact, however, that there are two saccules and two outlets in the Theraphosids does not appear to have been recognised by anyone.

\section{B. Araneae verae.}

In all the Araneae verae there is a single saccule lying mainly opposite the third appendage, but extending also posteriorly to about opposite the fourth appendage. The thin walls of the saccule are lined with delicate and sometimes flattened epithelium, and glomeruli lang into its lumen in the usual way. The saccule therefore preserves its typical appearance, but the labyrinth has become greatly reduced and simplified. According to the degree of simplification of the labyrinth the Araneae verae may be divided into three groups. In 
all of them there is an exit tubule with an outlet on the third appendage functional in the adult as well as in the immature. The collecting tubule has been lost and the lumen of the saccule passes directly into the labyrinth tubule.

\section{Group 1. Sicariids and Dysderids.}

The six-eyed Sicariids and Dysderids show the most primitive condition of the labyrinth. Starting from the main body of the saccule opposite the third appendage, it rums posteriorly as a single straight tubule as far back as the sixth appendage where it turns inwards, and then runs forward as a straight dilated tubule, internal to the first tubule, and along the endosternite to its outlet on the third appendage (Diagram A).

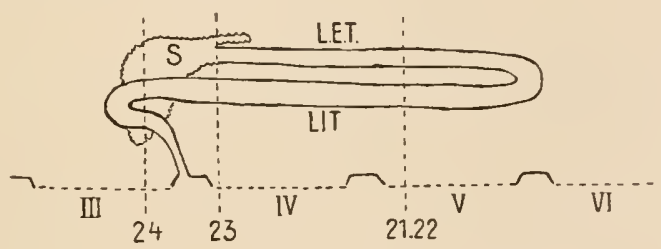

Diagram A.

Coxal gland of group 1 of the Araneae verae.

The saccule $(S)$ opposite appendage III, leads into the straight external tubule $(L E T)$ which runs posteriorly as far as appendage VI where it turus and rums as the internal tubule (LIT) anteriorly to the ontlet on appendage III. Both $(L E T)$ and (LIT) are lined with striated epithelium. The vertical broken lines indicate approximately the points throngh which transverse sections were cut from different specimens and photographs taken (21 to 24).

Since the labyrinth tubule rumning posteriorly from the saccule is, in the true spiders, always external to the other, it may be referred to as the external tubule $(L E T)$ and the tubule running anteriorly to the exit, as the internal tubule $(L I T)$, the two together composing the labyrinth. In Scytodes (Sicariid) there are a few loops at the posterior end of the labyrinth, but these are wanting. in Loxosceles (Sicariid) and Dysderc, in which the labyrinth simply runs backwards and then forwards again, so that in transverse sections one sees two tubules cut across, the external one leading from the saccule posteriorly; the internal one close to the endosternite, being the return tubule to the exit (photos 21, 22). 'The labyrinth cells have the usual striated base on which the large nuclei rest, 
but the cells are generally much worn down and the nuclei lie almost bare of cytoplasm on the free border of the striation.

Photograph 23 shows the passage of the saccule into the external tubule and photograph 24 the saccule and internal tubule. Diagram A explains of itself how the internal tubule at this point appears to be double. The photographs 21 to 24 are taken from sections cut transversely approximately at the points indicated by the broken vertical lines in the diagram.

Group 2. The hunting Lycosids, Thomisids, Attids, Drassids, Zodariids, Selenopids, Ctenids, and the imperfect web spinners, Agelenids and Dictynids.

The labyrinth in the members of this group of spiders shows very close resemblances, and one description will serve for all.

The walls of the external tubule leading posteriorly from the saccule, have become very thin and are lined with a flattened epithelium, the nuclei of which are not prominent so that the tubule resembles the saccule, and until the tubule is closely followed up from section to section it is often difficult or even impossible to determine which is the saccule and which the external tubule.

The external tubule rums, as in the Dysderid group, posteriorly to the sixth appendage where it turns forwards again. At the turn, or a little before the turn (photo 25, 25a) the lining epithelium changes its nature and becomes cubical and larger, remaining however relatively fine and delicate, and showing no evidence, or mere traces, of the striated base, which is such a marked feature in the typical labyrinth. The internal tubule is usually greatly dilated and shows dips towards the surface between the fourth and fifth, and the fifth and sixth appendages.

It has also dorsal extensions opposite the dips and also one opposite the exit. It would seem to serve the purpose of an extensive bladder rather than of an excretory gland (photo 26, 27) and probably the saccule alone has excretory functions. In some members of this group, e. g. the Zodariids (photo 28) the external tubule seems to have become actually fused with the saccule. The process of fusion appears to be due to glomeruli pushing in the thin wall of the tubule, so that its lumen becomes irregular and broken up, glomeruli hanging into it, as into the saccule itself: 
Diagram B.

Comparison between the coxal glands of the scorpious, pedipalps and spiders.

1. Scorpions. The saccule (S) surrounded by the labyrinth coils, which terminate in a resicular dilatation and an ontlet on appendage $\mathrm{V}$.

2. Pedipalps. From the saccule the coiled labyrinth tubule extends posteriorly as far as appendage VI, where it turns and runs straight forwards to the ontlet on appendage III.

3. The r a phosid spiders. The two saccules on appendages III and V communicate with the coiled labsrinth tubules and through them with the two outlets on III and V. The exact relations of the labyrinth with the saccules and outlets have not been determinerl.

4. Araneaeverae. Group 2. The Hunting spinders.

The saccule is extensive but the tubule learling from it posteriorly lias become straightened ont and the walls so thimued down that they often aplear fused with the saccule. The tubule leading anteriorly to the outlet on appendage III is greatly dilater and appears to act only as a resicle since the lining cells have lost their striation.

\section{Araneae verae. Web Spinners.}

The saccule is well preserved but the labyrinth has become fused with it, with the exception of a short resicular portion leading to the exit tubule and outlet on appendage III.

Zool. Jahrb., Supplement XIT. 
On comparing the photographs of the labyrinth of group 1 (photos 21, 22) with those of group 2 (photos 26, 27), it will be observed that although the tubules of group 1 are very much shortened as compared with those of the Theraphosids, yet the striation is very highly perfected; more so in fact than in any of the other Arachnids, except towards the anterior part of the internal tubule in the neighborhood of the saccnle (photo 24), where the striated part appears somewhat reduced and there is a tendency towards vesicular enlargement. It seems probable therefore that the excretory functions of the labyrinth of group 1 have not been in any way impaired, whereas in group 2, they have been entirely or almost entirely lost, and possibly, as suggested by Bersard, transferred to the production of silk.

Group 3. Epeirids, Theridiids, Pholcids, Filistatids.

In this group, the members of which are all expert web spinners, the labyrinth reaches its extreme limit of simplification. Practically nothing is left of this part of the gland but a short bladder $(V)$ leading to the exit tubule $(E T)$; the bladder opening above immediately into the saccule $(S)$ with its inhanging glomeruli $(G L R)$ (photos 29 to 32). The walls and epithelium of the labyrinth have become thinned down throughout, and so fused with the saccule that it is impossible to distinguish between them.

The well preserved condition of the saccule however and the well marked opening on the external surface, show clearly that the gland must be functional, although it would obviously be impossible to homologise such an organ with that of the other arachnids if it were not for the intermediate steps which can be traced back to the Theraphosids through groups 2 and 1 of the Araneae verae.

Diagrams $A$ and $B$ show roughly in a general way the main points of the difference and similarity between the coxal glands of the Scorpions, pedipalps and spiders, and the description attached to the diagrams will serve also as a summary for Part I. 


\section{Part II. Tracheate Arachnids and Peripatus.}

Tracheate Arachnids. Solifugae and Phalangids.

Specimens studied:

\section{Solifugae.}

\section{Galeodidae.}

Galeodes arabs, Biskra, Algeria.

Galeodes (sp.?), Biskra, Algeria.

Paragaleodes barbarus, Biskra, Algeria.

Paragaleodes scaluris, Biskra, Algeria.

\section{Solpugidae.}

Solpuginae. Solpuga flavescens, Biskra, Algeria.

Doesince sp? Colombia.

Doesinae: Ammotrecha, Texas (alc. sp. M.).

Eremobatinae: Eremobates, Texas (alc. sp. MI.).

In the description of the coxal gland of the solifugae we shall find so many new and remarkable features, that the inferences drawn may very likely be erroneons in some respects. But in order to avoid, as far as possible constant repetition of "I think" or "I believe", I shall treat the subject dogmatically and appear to take it for granted that my views are correct.

The coxal gland lies loosely in the hemocoele; the loops and coils of its tubules extending posteriorly as far as the sixth appendage. The main portion of the gland lies between the second and third appendages and from this point a long narrow tubule runs anteriorly with an outlet on the second appendage. The more detailed description of the gland given below applies to Paragaleodes. Variations from the type of Paragaleodes in other genera will be commented upon later.

Beginning with the saccule $(S)$ which lies in the main portion of the gland we find thas it hat undergone considerable modification. Since the solifugae, being tracheate animals, have no system of blood vessels outside of the long narrow heart $(H)$, there is no means of carrying blood directly to the gland as in the pulmonate scorpions, pedipalps and spiders. 'T'o remedy this defect, the saccule appears to have been developed into a pumping organ designed to force fluid from the hemocoele into the coxal gland. All around the periphery of the saccule are attached bands of finely striated muscle fibres (MS) which radiate out on all sides (photo $33,34,34 \mathrm{a}, 34 \mathrm{~b}$ ) and 
at their distal ends attach themselves to anything which crosses their path; walls of tracheae $(T R)$, tubules of the coxal gland, or to other muscle bundles.

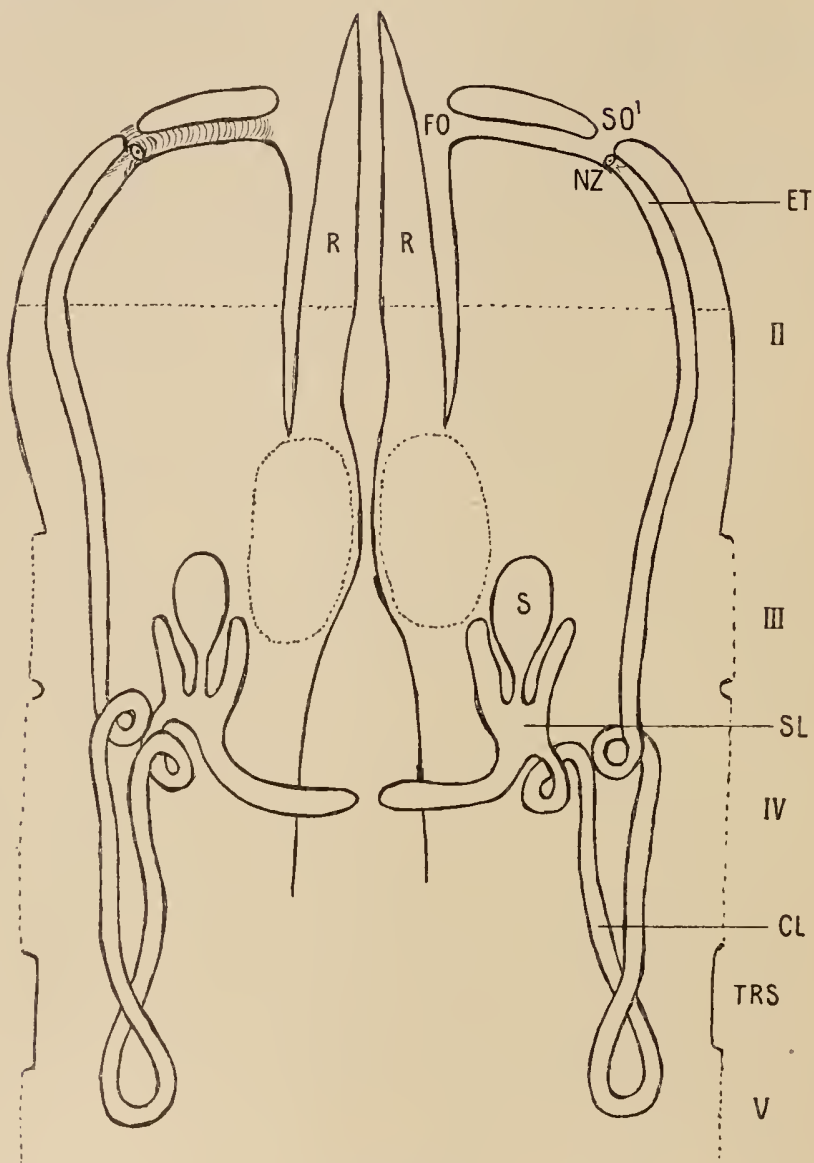

Diagram C.

Galeodes (? Othoes). Frontal view.

Shows in a general way the disposition of the coxal glands.

The saccule $(S)$ and collecting tubule passing into the labyrinth sac $(S . L)$ (only partially drawu; the posterior extension is omitted) which changes to the coiled tubule of the labyrinth $(C L)$. The tubule $(C L)$ runs posteriorly and then anteriorly again to the exit tubule $(E T)$, terminating in the nozzle $(N Z)$. In this species there is a definite tubule beyond che nozzle with its side outlet $(S O)$ and final outlet $(F O)$ not far from the opening of the rostrum to the exterior.

In the diagram the tubule has been drawn pointing a little too much inwards. It should have been drawn more obliquely. (Compare with photo 8.) The rostrum $(R)$ with its sucking chamber lies in front, and the sucking chamber passes posteriorly into the narrow oesophagus between the two lobes of the brain (dotted ovals). The straight dotted line above indicates approximately the level at which the chelicerae project from the body above appendage II. 
It is obvious that when these muscles are contracted the walls of the saccule would be pulled out, the lumen would become distended, and filled with fluid filtering in through the walls. On relaxation of the muscles, the saccule would tend to collapse upon itself, and press upon the contained fluid which would thus be forced through the collecting tubule into the labyrinth.

To increase the extensibility and also no doubt to strengthen the walls of the saccule, they are reinforced internally by a thick layer of spongy cellular tissue (photo 33), between the cells of which run innumerable tine fibres, which may be extensions of the muscle fibres, but the fibres themselves do not appear to be contractile. Although the cells of the spongy tissue have lost all appearance of epithelium they are probably derived from the original epithelial lining cells of the saccule.

There is a considerable lumen (CSL) in the center of the saccule, and pouches from the central lumen extend into the spongy

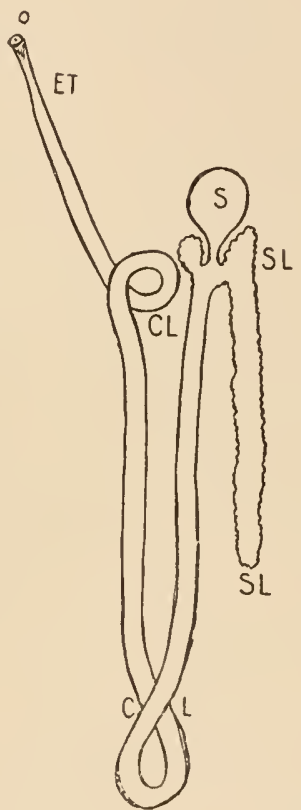

Galeodids

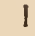

[]

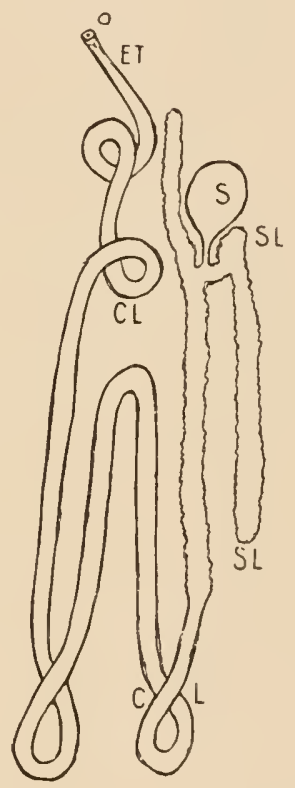

V!

Solpugids

Diagram $\mathrm{D}$.

Showing an outline of the coxal glands and the way in which a second extension posteriorly of the labyrinth sac in the Solpugids has led to the change from $S L$ to $C L$ being removed for some distance from the main part of the gland. In the Solpngids also the coiling of the labyrinth tnbule is much more complicated than in the Galeodids. tissue on all sides (photos $34,34 \mathrm{a}, 3+\mathrm{b}$ ).

Although this part of the organ has undergone such striking modification that by itself it could no longer be recognised as the 
saccule, there can remain little doubt that it does actually represent the saccule when its relations with the rest of the gland are taken into consideration.

At one point in the central lumen of the saccule a funnel like collecting tubule with definite epithelial lining begins and runs as a long narrow duct opening into the labyrinth (photo 35). The labyrinth can be divided into two very distinct parts, the first of which is not a system of coiled tubules, but is more of the nature of a sac with innumerable pouches (photos 37, 37a). The German word "Schlauch" would best describe it, but it may be called the "sac of the labyrinth", or "labyrinth sac" $(S L)$ to distinguish it from the true saccule.

In its simplest form (Paragaleodes), the long narrow multipouched sac runs posteriorly to a little beyond the tracheal stigmata (TRS) of the thorax which lie in a space between the fourth and fifth appendages (Frontispice and diagram D), where it ends blindly. The walls of the labyrinth sac are lined throughout with tall columnar epithelium without any striation (photos 36, 37 and $45(S L)$ show this best); the closely packed nuclei lying at the base of the cells immediately over the limiting membrane of the wall.

The lumen of the sac is sometimes filled with a granular detritus and when this is the case the cells appear worn down and indistinct (photos $37 \mathrm{a}, 42 \mathrm{a}$ ). This part of the labyrinth appears therefore to be a secreting rather than an excreting organ and may be considered as such provisionally.

The structure and the cells of this part of the coxal gland are something quite different from anything we have hitherto encountered in the labyrinth and for some time I considered it to represent the saccule in a modified form, and took the saccule to be a new structure of the nature of a glomus, but this view proved to be erroneous.

I find that BERNard appears to take this mistaken view of the situation. He observed the two distinct parts of the labyrinth and considers that the proximal part (labyrinth sac, of this article), can be homologized with the proximal or medullary part (Lankester) of the coxal glands of the scorpions. But he overlooked the true saccule and collecting tubule altogether and thought the outlet was on the third appendage, so that his observations at any rate were incomplete and in some respects actually erroneous. BERNaRd also discusses the question whether these proximal parts of the glands 
in the solifugae and scorpions can be considered as the remnants of the coelom or not, and comes to the conclusion that they cannot be so considered, but are simply modifications of the ordinary labyrinth tubule; also a mistaken view in all probability.

At a point in close proximity to the saccule, the sac of the labyrinth $(S L)$ passes abruptly into the second part of the labyrinth $(C L)$ (photos 36, 36a) which is typical in every respect. We find here the coiled tubules lined with cells having the typical striated base upon, or just within, which the nuclei are placed. From its opening from the secreting sac (diagram D, Galeodidae) the tubule runs posteriorly as far as the sixth appendage, where, after forming a few coils, it turns and runs anteriorly again to the main part of the gland. Here, after coiling a little upon itself, it passes on anteriorly as an almost straight tubule to the base of the second appendage.

As the exit tubule (ET) it then extends forwards along the dorsal side of the coxal joint of the second appendage just underneath the chitinous tegument its walls becoming muscular (photo 38), to its ontlet at a point about opposite the front of the median eyes, and just below the base of the chelicera. The tubule here turns a little inwards and terminates in a strong chitinous ring with a minnte orifice in its center, which acts as a nozzle $(N Z)$ (photos 38, $38 \mathrm{a}, 38 \mathrm{~b})$.

The nozzle lies in a groove, formed by two flaps of the chitinous integument, which extend as a sheath $(L R)$ for some distance further forwards and provide a kind of conduit for the fluid ejected from the nozzle (photo 40, 40a).

The second appendage (palp) is always directed forward and the dorsal aspect of its coxal joint works under, and rubs against the ventral surface of the enormously developed first appendage (chelicera), so that this extension of the exit tubule and the chitinous sheath beyond its outlet run anteriorly and finally a little in wards.

Since the natural position of the outlet would be at the base of the coxal joint of the appendage it seems probable that this anterior extension of the tubule along the coxa, with its muscular walls and nozzle like outlet, must be a secondary development designed to serve a special purpose, and in fact the outlet is situated at a point from which fluid ejected with some force would be pro- 
jected towards the outlet of the rostrum and the prey held by the chelicerae in front of the rostrum.

The apparatus for forcibly ejecting the fluid is there. and, the chitinous sheath through which the stream passes would keep it in the right direction, since in the solifugae the mouth parts, instead of being situated ventrally, as in the spiders and pedipalps, are directed straight forward, the rostrum $(R)$ forming a sucking chamber $(K S)$ in front of the mouth proper, and extending anteriorly between the chelicerae (photo 39).

The solifugae have a bad reputation in many places as poisonous animals, but no definite poison glands, such as exist in spider's and scorpions, have ever been found. Pocock suggests that the poison may exude from small setal glands situated in the teeth of the chelicerae, but I do not know that this has ever been demonstrated, and it seems more probable that the poison, if there is any, is the product of the coxal gland.

When the coxal glands were first observed in the solifugae they were taken for poison glands (in: Cambridge nat. History), but this view was refuted and the glands are now considered to be excretory, and homologous with the coxal glands of other arachnids. However it is possible that the older observers were not so far wrong after all.

In any case the coxal gland would appear to act as a salivary gland. In the spiders and scorpions special salivary glands have been evolved on the coxal joints of those appendages which are situated closest to the mouth and do most of the masticatory work. Such salivary or buccal glands in the spiders are localised at the base of the coxal joint of the second appendage, and in the scorpions of the third and fourth appendages, but are quite independent of the coxal or poison glands. There are no such separate buccal glands in the solifugae which affords an additional reason for supposing that the coxal glands perform the duty of salivation.

Briefly then the spider's and scorpions have three distinct sets of glands, poison, salivary and excretory, but in the solifugae all these duties are performed by the coxal glands, parts of which are specially modified for the purpose.

Before concluding, a few additional observations may be recorded. With regard to the saccule; in some specimens of Paragaleodes, on one side of the animal the collecting tubule is open, and its course can be readily traced from the saccule to the labyrinth sac (photo 41 , 
41 a), but on the other side of the same specimen the collecting tubule is closed by a bulge $(B)$ from the wall of the labyrinth sac (photo 42, 42 a) the bnlge protruding also into the lumen of the saccule (photo 46 is a compound of 41 and 42 ).

It appears that the muscle fibres of the saccule on this side are contracted, and in pulling out the walls of the saccule a partial vacumm is temporarily formed in its lumen, and the labyrinth sac, which surrounds the collecting tubule, closes up over it; forming a valve which prevents any back flow through the tubule from the labyrinth sac, thus allowing the saccule to fill up again with fluid from the hemocoele ontside. As the muscles become relaxed the tubule opens again and fluid is forced from the saccule into the labyrinth.

In connection with the saccule, it may furtler be remarked that the tissue composing it varies much in different genera (compare photos 34, $34 \mathrm{a}$ and $34 \mathrm{~b}$ ). In Paragaleodes (34) it is very loose and porous; less so in Solpuga (34a) and in Galeodes (34b) relatively compact and dense. The tissues surrounding the saccule also show the same progressive condensation. Finally in the specimen Galeodes $s p$.? not only is the tissue of the saccule very compact, but the special muscles (MS) appear to be wanting, so that it is doubtful if there can be any pumping action. ${ }^{1}$ )

'The collecting tubule is usually long and narrow, lined with epithelium differing fiom that of the labyrinth sac on the one hand and from the cells of the saccule on the other, but in the specimen of a Galeodes just mentioned, the collecting tubule appears to be lost as a separate entity, and the change from the cells of the saccule to the colummar cells of the labyrintli is abrupt as is shown in photograph 45, but the collecting tubule is in the usual place between two pouches of the labyrinth sac. It may be that the loss of the pump and the alteration in the character of the collecting tubule liave some connection with each other:

In this specimen also the colmmnar cells of the labyrinth sac $(S L)$ are much more regularly disposed than in any other examined, and the columnar character is even retained in the cells of the

1) I am now inclined to think that this specimen belongs to the genus Othoes of the Galeodidae (Nov. gen. Hrrst 1910). In its internal organisation it differs considerably both from Grdcodes and Puragalcodes, yet stands nearer to them than to the Solpugids. 
labyrinth coils $(C L)$, but in $C L$ the nuclei are raised from the base of the cells, and lie upon a striated border, the striation however being less conspicuous than is usual. A general view of this specimen with the coxal glands and their relation to other parts of the cephalothorax is shown in diagram $\mathrm{C}$.

As to the labyrinth, the description given of it applies to the Galeodids, in which the coils and twists are few and the tubules can be followed up without difficulty throughout their course, but the Solpugids, although fundamentally the arrangement is the same as in the Galeodids, have a much more complicated labyrinth, but it will be sufficient to refer to the diagram D, which shows how the labyrinth sac has developed a second extension posteriorly, dragging with it the point of change to the striated tubule, so that the change in this case is far removed from the main part of the gland. The striated tubules also become so greatly coiled in the Solpugids that it is impossible to follow them accurately throughout their whole length (photo 43).

There is much more coiling and twisting than is indicated in the diagram of the Solpugids but that of the Galeodids shows approximately all the coiling. In neither case however has any attempt been made to show in the diagram $\mathrm{D}$ the pouching of the labyrinth sac, a better idea of which can be obtained from the photographs (37 and 37 a).

The pouching of the labyrinth sac is most conspicuous in Paragaleodes. In the Solpugids and Galeodes the pouches are fewer but individually longer:

The chitinous groove or sheath along which the stream from the nozzle is directed towards the rostrum varies somewhat in appearance in the different genera. In Paragaleodes it is short and imperfect, but in Solpuga much better developed, forming a long forwardly projecting sheath standing out from the coxa of the appendage (photos 40, 40 a). Finally in Othoes (?) it is converted into a definite tubule lined with epithelium which, starting from the nozzle, runs inwards with a outlet just before reaching the rostrum (photo 39, LR and diagram C). There is however a side outlet just beyond the nozzle, the object of which would appear to be to allow excretory products to dribble out during a period of quiescence, and probably this side outlet is closed and the fluid forcibly ejected through the tubule beyond it for salirary purnoses.

The side outlet is present also in other genera and in the photo- 
graph 44 of a transverse section from Eremobates can be seen on the left of the rostrum at $(S O)$. Just anterior to this point the sheath closes up again and proceeds to the final outlet ( $F O$ in photo 39), a little further forwards. The photograph 44 and diagram C show that the side outlet is directed away from the mouth, whereas the final outlet is directed towards it.

It seems strange that there is no definite vesicle or reservoir near the outlet for storing the products of secretion since these have to travel so far before reaching the exterior, but the exit tubule appears to be distensible. The photograph $38 \mathrm{~b}$ shows this condition of distension as observed in a single specimen of Solpuga, but in all other specimens examined the tubule is narrow and contracted as in photographs $(38,38$ a). Perhaps at the moment of death the muscles usually contract and drive out any secretory products which may be present in the exit tubule.

\section{Phalangids.}

The Phalangids have not been studied at all closely, but in the few specimens examined, the labyrinth is clearly marked out, and there is an outlet on the fifth appendage. The saccule is small and surrounds the exit tubule, but I have been unable to find the communication between it and the labyrinth through the medium of a collecting tubule. These observations simply confirm those of Bruxtz. Bruxtz also mentions that there is always a large nerve passing through the folds of the saccule. This observation, I can also confirm.

Summarising the knowledge thus far gained we find that in the coxal glands of the scorpions, pedipalps and true spiders there is a saccule, a collecting tubule, a labyrinth with striated cells, and an outlet either on the third or fifth appendage, while the primitive Theraphosid spiders have two saccules and two outlets; one corresponding to the third and the other to the fifth appendage.

In these groups then the coxal glands appear to be quite lomologons, but the solifugae possess in addition a secreting sac and the outlet is on the second appendage not far from the month, so that the gland acts as a salivary as well as an excretory organ and also possibly as a poison gland.

On examining, without any special object in view, some sec- 
tions of Peripatus (specimens given by Dr. Alexander PetrunkeviтCH and Dr. M. Grabham of Jamaica), I was astonished to find that they threw a great deal of light npon the reasons for these differences in the coxal glands of the Arachnids.

\section{Peripatus.}

Specimens examined:

$P$. juliformis. IIale (Petrunkevitch, fixed in sublimate).

P. jamaicensis. Female (Petrunkevitch, fixed in sublimate).

$P$. julliformis and $P$. jamaicensis (GrabHan, preserved in formol).

All of the above were collected in Jamaica and in addition I have examined three adult females containing embryos, of $P$. nicaraguensis var. isthmicola (Bouvier) collected by myself in Costa Rica and fixed in DuboscQ's solution.

Peripatus has a variable number of legs, ranging from sixteen in the Australian species to about forty in $P$. jamaicensis, and in front of the legs are two segments; the jaws, corresponding to the chelicerae, and the oral papillae. corresponding to the palps of the Arachnids. The antennae, corresponding possibly to the rostrum of the Arachnids arise from the pre-oral segment (SFDGWICK) and are not here considered to have any segmental value.

On each of the leg bearing segments of Peripatus there is a nephridium; the first five and the last three of which, irrespective of the number of legs, are modified from type. Thirty legs is the usual number for the American species and in describing the nephridia it will be convenient to take the number of legs as thirty, and the segments therefore as thirty-two. The genital segment near the posterior end has no nephridium, but the posterior segments have no bearing on the present argument, so for the sake of brevity the genital segment will be disregarded.

The typical nephridium found on segments eight to twenty-nine possesses a saccule $(S)$ from which a fumnel bearing collecting tubule $(C T)$ leads into the labyrinth $(C L)$ with its striated cells and nuclei in the usual position (photos 47, 47a) but the striation is not so clearly marked as in the Arachnids. The diagram $\mathrm{E}$ indicates roughly the way in which the labyrinth coils and finally enters the vesicle, but for a short distance at the loop ( $L M$, of diagram and photographs), the lining cells take on a totally different character. The striation is lost and the nuclei lie at the base of 
tall columnar cells, containing basophil granules; cells therefore which appear to have secretory functions (photos 47 to $47 \mathrm{~d} L M I$ ).

The nephridia of segments six and seven, on legs four and five. have become modified from type in the sense that the labyrinth is very extensive; its tubules forming complicated twists and turns, but the modified secretory portion of the labyrinth is entirely lost. The vesicle has also disappeared, so that from the collecting tubule, to the exit tubule there is an unbroken stretch of labyrinth with striated cells, as in the scorpions, pedipalps and theraphosid spiders.

In the modified nephridia of the first three and last three legs on the contrary it is the striated portion of the labyrinth which is entirely missing. The short collecting tubule passes directly into a tubule lined with cells resembling those of the modified part of the typical labyrinth; this tubule proceeding straight to the exit tubule without any vesicular enlargement (photo 49 N.M).

The modified nephridium of the second appendage, known as the salivary gland, presents some very remarkable features. The saccule and collecting tubule can readily be found and recognised in photos 48 , $50,50 \mathrm{a}, 50 \mathrm{~b}$, but the collecting tubule opens into a diverticulum (photo $51 \quad D S L$ ) from a long

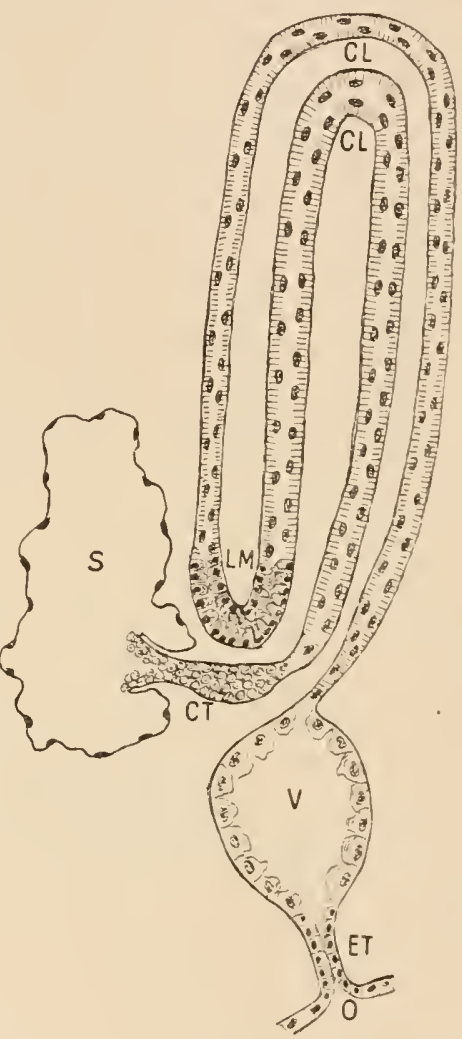

Diagram E.

Typical nephridium of Peripatus. The sacenle $(S)$ passes into the fumnel bearing collecting tnbule $(C T)$. The striated part $(C L)$ coils npon itself, and at the bend in close proximity to the collecting tubule, there is a short stretch lined witl epithelim of a secretory nature $(L, M)$ beyond which the striation begins again, the tubnle finally passing to the resicle and ontlet at the base of the appendage. narrow sac $(S L)$, which extends posteriorly almost to the end of the body (diagram F 1). occupring a space in the lateral sinus, dorsal to the segmental nephridia. The sac is almost straight, but shows a tendency towards pouch- 
ing, and may or may not be filled with products of secretion (photos 50 and $52 S L$ ). The lining cells vary somewhat in different parts of the sac, but all are of the fundamental type of a secreting cell; those in the diverticulum leading to the collecting tubule being filled with basophil granules (photos $50,51 D S L$ ), resembling very closely those of the cells of the modified part of the labyrinth in the typical nephridium (diagram E $L M$, and photo $47 \quad L M$ ) of which modified part the entire sac is probably a gigantic extension and further modification. A comparison of the basophil granules in the diverticulum $(D S L)$ of the salivary gland, with those in the modified part $(L M)$ of the typical nephridium, and of the short tubule of the small modified nephridia is made in photographs 54, 54a, 54 b.

Not far from the collecting tubule and ventral to it (diagram F 1) the sac opens into a tubule lined with striated cells (ploto $53 C L$ )

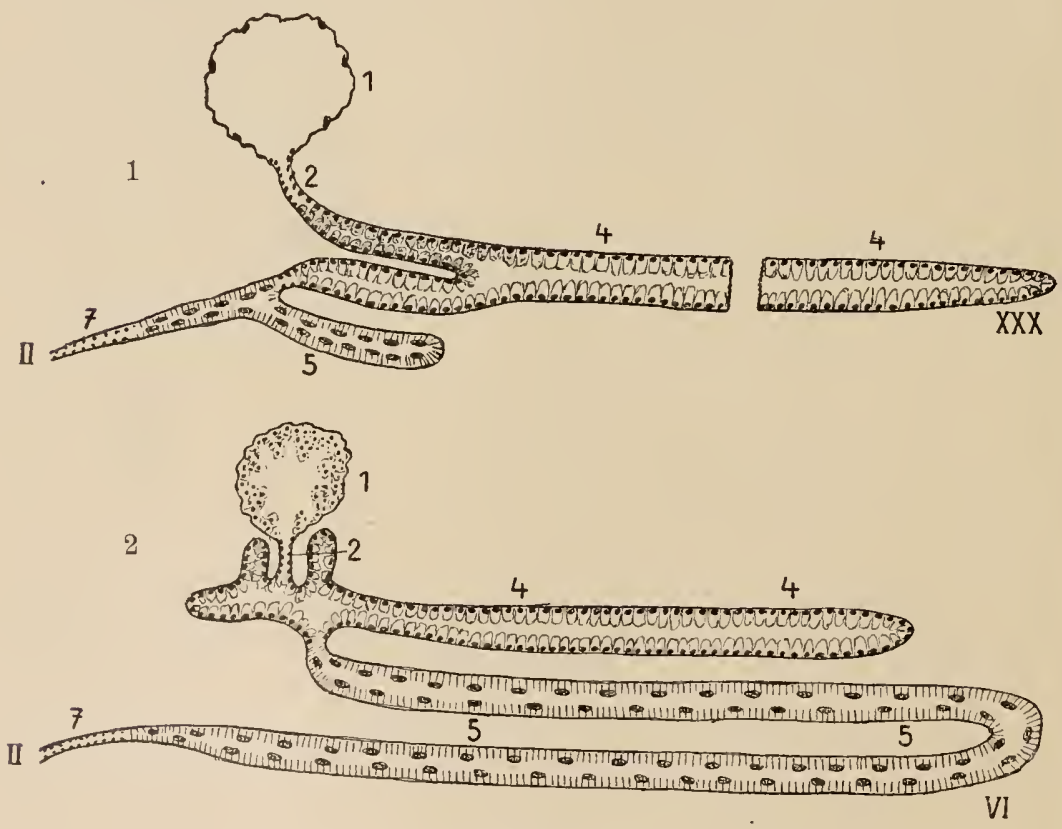

Diagram F.

Comparison between the salivary gland of 1 . Peripatus and the coxal gland of 2 . the solifugae.

The figures refer to the parts corresponding to those of the typical nephridinm in diagram $\mathrm{G} 1$.

1 Saccule. 2 Collecting tubule. 3 Missing. 4 Labyrinth sac. 5 Striated part. 6 Jissing 7 Exit tubule. 
which shortly passes into the exit tubule. The exit tubule joins with that of the other side, and the two have a common outlet just behind the month. There is a diverticulum from the striated division, running posteriorly $(C R)$, called the "reservoir" by Bouvier, the position of which can be gathered from the diagram (F1).

Bouvier (1905), whose magnificent work is mainly systematic, does not figure the saccule and collecting tubule of the salivary gland, but they have been described and figured by v. Kennes (1886) in embryos of the American species $P$. edwardsii and $P$. torquatus. v. Kexnes however says that in the adult the saccule disappears and the collecting tubule is closed.

SEDGWrck (1888) also describes the saccule and collecting tubule of the salivary gland in embryos of $P$. capensis, remarking that they persist in the adult, and this is certainly also the case in the specimens examined by myself, in all of which the saccule is clearly present and the collecting tubule open. In P. nicaraguensis (photo 50) the saccule and collecting tubule are somewhat reduced in size as compared with those of the typical nephridium, but in $P$. jamaicensis (photos 48, 50 a) they appear quite normal.

Peripatus also aftords an excellent example of the way in which the extension of one organ, may lead to atrophy of others which were originally its equal. In most species of Peripatus the striated diverticulum (reservoir) of the salivary gland extends posteriorly to the third leg, and the nephridia of the first three legs lave lost their striation. In $P$. jamaicensis however the striated part of the salivary gland stretches back as far as the twelfth leg, according to Bourier, although in my specimens it does not extend beyond the seventh or eighth leg. However this may be the nephridia of legs six to twelve inclusive have all become modified in the same manner as those of the first three legs, that is, they are very small and have lost their striated part and vesicle. But this modification does not affect the large nephridia of the fourth and fifth legs, which in $P$. jumuicensis are relatively larger and the striation of the cells more distinct than in the other two species examined. It is difficult therefore to be sure whether the salivary reservoir or the large nephridia of legs four and five have had most effect in redncing those which lie more posteriorly, but the fact remains that in $P$. jamaicensis the excretory functions of the first fourteen segments are performed by three large systems of well defined striated tubules, whereas other species, in which 
these three systems are less developed, possess in addition seven smaller systems of striated tubules in the first fourteen segments.

The similarity of the salivary gland of Peripatus to the coxal gland of the solifugae is most striking (diagram F1 and 2) and there can be little doubt that they are homologous organs; the long narrow sac in each instance being an extension of the original modified part of the labyrinth which can still be recognised in the typical nephridia of Peripatus. Both have this extensive secreting sac, which may or may not be filled with products of secretion (photos 37, 37 a of solifugae and 51, 52 of Peripatus), and the outlet on the second appendage close to the mouth opening.

The saccule in both cases lies anteriorly to the collecting tubule, and the collecting tubule itself passes posteriorly to the labyrinth sac; a point which has not been sufficiently indicated in the diagram $(\mathrm{F})$.

With regard to the ontlet in the solifngae we may infer that as the mouth opening extended forwards the exit tubule of the salivary or coxal gland had to follow it along the coxal joint of the palp, and finally reaching a point where the joint begins to turn outwards (Frontispice B of entire animal, ventral view), the exit tubule itself could extend no further forwards so developed the squirting. arrangement which has been described, and the chitinous sheath to keep the fluid in the right direction.

The coxal glands of the scorpions, pedipalps, and spiders on the other hand appear to have lost the modified part of the labyrinth and resemble in a general way the large nephridia found in two of the segments of Peripatus, except that the outlets are on the third or fifth appendages with indications of lost ontlets on the fourth and sixth, and not on the sixth and seventh as in Peripatus.

In the scorpions and spider's, as we have seen, special poison and salivary glands have been developed for these parts of the work, but such special glands are absent in Tarantula. The outlet of the coxal gland of Tarantula on the third appendage is not far from the ventrally placed mouth, and we have seen that in the middle part of the labyrin th the cells are columnar and basophil, so it is possible that they act as secreting cells, and that the coxal gland in this case also plays the part of salivary as well as of excreting gland. However these cells of the middle part of the Tarantula labyrinth have the usual striated base on which the nuclei rest, and do not resemble in this respect the secretory cells of the labyrinth sac in Peripatus and Galeodes. If then these cells are actually secretory it is probable that they have 
become so secondarily and do not represent the modified part of the Peripatus labyrinth.

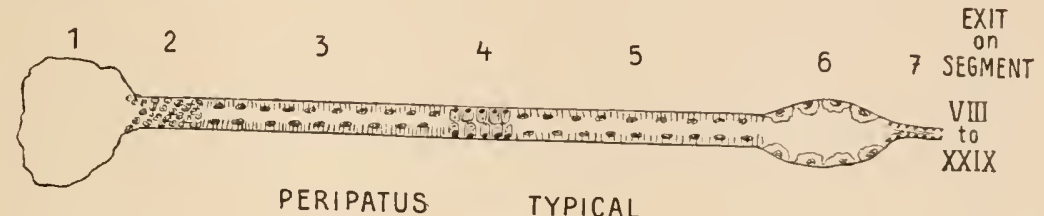

PERIPATUS TYPICAL

2.

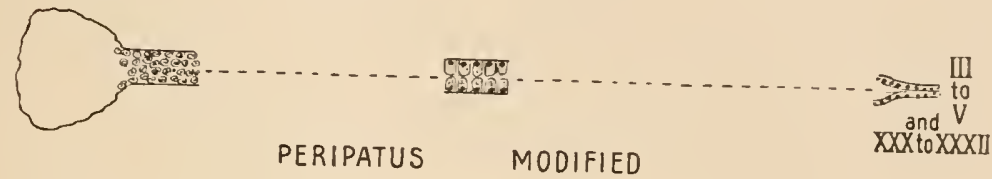

3.

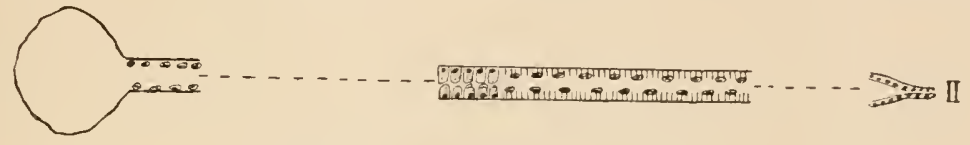

\section{PERIPATUS SALIVARY GLAND}

4.

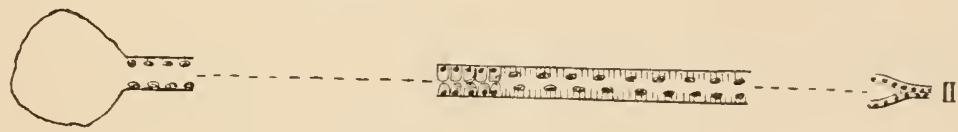

SOLIFUGAE COXAL GLAND

5.

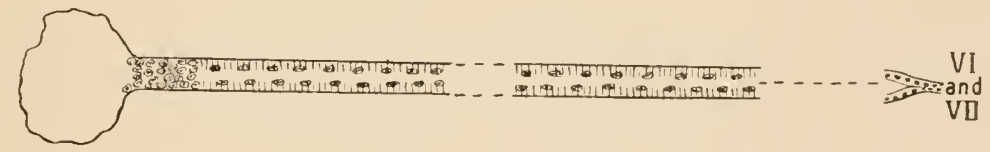

PERIPATUS TWO LARGE NEPHRIDIA

6.

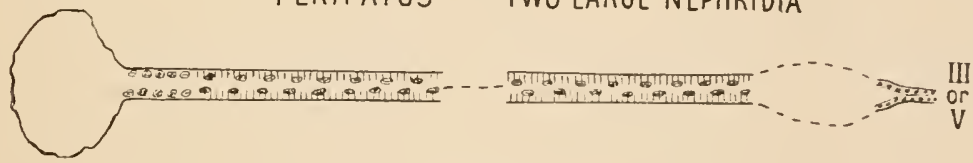

Diagram G.

The typical and modified nephridia of Peripatus compared with each other and also with the coxal glands of the Arachnids.

The relative sizes of the different parts are approximately shown in 1 , but in the other figures it bas simply been attempted to show which of the original parts have been preserved, and which are missing, without regard to the relative sizes of the parts.

1 Saccule. 2 Collecting tubule. 3 First striated excretory part. 4 Modified secretory part. 5 Second striated excretory part. 6 Vesicle. 7 Exit tubule.

Those parts of 1 which are missing in the other figures are represented by a single broken line, and donbtful parts by a donble broken line.

In diagram $G$ a comparison is drawn between the nephridia of Peripatus and the coxal glands of the Arachnids. In the typical Zool. Jahrb., Supplement XIV. 
nephridium of Peripatus (1) the relative sizes of the component parts are approximately given, but for the other figures it has merely been attempted to indicate which of the original parts have been preserved or lost without regard to their relative size. In the scorpions and higher spider's we find a vesicular enlargement just before the exit tubule is reached, but it does not appear that this vesicle can be homologized with that of the typical nephridium in Peripatus. In neither scorpions nor spiders is the vesicular enlargement lined with cells differing from those of the labyrinth, nor has it any regularity of shape. The vesicle (6) therefore in the last figure of the diagram is drawn as "doubtful".

If the hypotheses here suggested as to the origin of the coxal glands are correct it would seem that the parent stock of the solifugae must have been different from that of the other Arachnids since they appear to have descended from a branch of the original stock in which the salivary glands had become paramount, whereas in the parent stock which gave rise to the other Arachnids, the salivary gland of the second appendage had retrograded, and the nephridia situated on the third to the sixth appendage had become the most important; developing along lines similar to those of the sixth and seventh appendages in Peripatus.

So far as I am aware the new observations are:

Scorpions. Blood supply to saccule from artery of appendage $\mathrm{V}$. Lymphatic organ wanting in Buthids but present in the other families.

Pedipalps. Saccule and collecting tubule opening into labyrinth. Columnar cells in labyrinth of Tarantula confined to the middle division.

Spiders. 'Theraphosids. Two saccules, each with its collecting tubule opening into the labyrinth, and two outlets.

Araneae verae. Saccule and its communication with the disappearing labyrinth.

Solifugae. Modified saccule with pump and collecting tubule. Ontlet on appendage II with squirt and projecting sheath.

Peripatus. Modified (secretory) portion of the labyrinth of the typical nephridium (?).

Modified nephridia of legs six to twelve in $P$. jamaicensis.

Homology of the salivary gland in Peripatus with the coxal gland of the solifugae.

Homology of the coxal glands of the other Arachnids with the large nephridia of Peripatus on legs four and five. 


\section{Literature.}

BERnaRD, H. MI., The comparative morphology of the Galeodidae, in: Trans. Linn. Soc. London, Vol. 6, 1896, p. 377.

Solifugae.

Bertkad, Ph., Ueber den Verdauungsapparat der Spinnen, in: Arch. mikrosk. Anat., Vol. 24, 1885.

Spiders.

Börner, C., Beiträge zur Morphologie der Arthropoden. I. Ein Beitrag zur Kenntnis der Pedipalpen, in: Zoologica, Vol. 17, 1904, p. 95.

Bouvier, E. L., Monographie des Ouychophores, in: Ann. Sc. nat. (9), Zool., Vol. 2, 1905, Vol. 5, 1907.

Pedipalps.

Peripatus.

Brader, A., Beiträge zur Kenntnis der Entwicklungsgeschichte des Skorpions, in: Z. wiss. Zool., Vol. 57, 1894, Vol. 59, 1895.

Bruxtz, L., Contribution à l'étude de l'excrétion chez les Arthropodes, in: Arch. Biol., Vol. 20, 1904.

Scorpions.

Arachnids.

GougH, L. H., The development of Admetus pumilio KoCH, in: Quart. Journ. microsc. Sc., Vol. 45, 1902.

Pedipalps.

v. Kennel, J., Entwicklungsgeschichte von Peripatus Edwardsii BLANCH. und Peripatus torquatns n. sp., in: Arb. zool.-zoot. Inst. Würzburg. Vol. 7, 1884, Vol. 8, 1886.

Peripatus.

Kowalevsky, A., Une nouvelle glande lymphatique chez le scorpion d'Europe, in: Hem. Acad. Sc. St. Pétersbourg (8), Vol. 5, 1897.

Scorpions.

Laurie, M., On the morphology of the Pedipalpi, in: Journ. Linn. Soc. London, Zool., Vol. 25, 1894 , p. 29 .

Pedipalps.

Marchal, P., La glande coxale du Scorpion, in: CR. Acad. Sc. Paris, Vol. 115,1892, p. 191.

Scorpions. 
Patten, W. and A. P. Hazen, The development of the coxal gland, branchial cartilages and genital ducts of Limulus polyphemus, in: Journ. Morphol., Vol. 16, 1900.

Peldeneer, P., On the coxal glands of Mygale, in: Proc. zool. Soc. Iıondon, 1885.

Pereyaslawzewa, S., Développement embryonnaire des Phrynes, in: Ann. Sc. nat. (8), Zool., Vol. 13, 1901 , p. 232.

Limulus.

Theraphosids.

Pedipalps.

Schimкеwitsch, L. und W., Ueber die Entwicklung von Telyphonus caudatus (L.), in: Z. wiss. Zool., Vol. 81, 1906.

Thelyphonus.

-, Ein Beitrag zur Entwicklungsgeschichte der Tetrapneumones, in: Bull. Acad. Sc. St. Pétersbourg (6), Vol. 5, 1911.

Theraphosids.

SEDGWICK, A., The development of the Cape species of Peripatus, pt. 4, in: Quart. Journ. microsc. Sc. (N. S.), Vol. 28, 1888, p. 387.

Peripatus.

Sturany, R., Die Coxaldrüsen der Arachnoideen, in: Arb. zool. Inst. Wien, Vol. 9, 1891.

Arachnids. 


\section{Explanation of Plates.}

\section{Part I. Pulmonate Arachnids.}

$C$ Coeca of intestinal tract

$C A$ Coxal Artery

CL Coxal labyrinth

CSL Central lumen of saccule

$C T$ Collecting tubule

$D$ Diaphragm

END Endosternite

ET Exit tubule

$E Y T$ External surface

$G$ Genital duct

$G L$ Glomus

$G L R$ Glomeruli
GN Ganglion

LET External tubnle of Iabyrinth

$L I T$ Internal tubule of labyrinth

$L O$ Lymphatic organ

M Muscle

$N$ Nerve

O Outlet

$S$ Saccule

$\checkmark$ Vesicle

$V S$ Ventral sinus

VTL Ventral tubule

The photographs are so arranged that on reading the lettering, the dorsal side of the specimen is uppermost in sagittal and transverse sections, and the anterior end is uppermost in frontal sections.

\section{Scorpions.}

\section{Plate 1.}

Fig. 1. Vejovis flavies. Sagittal. 100:1.

Coxal gland showing the saccule surrounded by the labyrinth coils. The coxal artery $(C A)$ enters the saccule $(S)$, and on the right the lumen of the saccule passes into the labyrinth tubule $(C L)$. Below on the left is appendage $V$ with its nerve $(N)$ and artery $\left(A T^{\prime}\right)$.

From $A V$ runs the coxal artery $(C A)$ to the saccule.

The diaphragm $(D)$ runs vertically across the field just posterior to the coxal gland. On the right of $D$ is the abdomen with its intestinal coeca $(C)$ filled with globules of nutrient matter. The lymphatic organ lies more internally and does not appear in this section. 
Fig. 1a. Buthus australis. Immature. Sagittal. 100:1.

A view of the coxal gland corresponding to that of 1 . The difference in the size of nuclei and cells in the two different species is noteworthy.

\section{Plate 2.}

Fig. 1b. Vejovis flavies. Sagittal. 300: 1 .

Coxal gland. Passage of saccule into labyrinth.

A part of photograph 1, more highly magnified.

Fig. 1c. Buthus occitanus. Adult. 200:1.

Coxal gland. Passage of saccule into labyrinth. The striated part of the labyrinth cells is stained black with iron hematoxylin.

\section{Plate 3.}

Fig. 2. Buthus occitanus. Young with mother. Sagittal. 300:1.

Vesicular part of coxal gland with exit tubule (ET) and outlet $(O),(E X T)$ is the exterior between appendages $\mathrm{V}$ and VI. $225: 1$.

Fig. 3. Centrurus margaritatus. Egg just before birth. Frontal.

Coxal gland with dip of labyrinth coils almost to surface (EXT) on appendage VI. The saccule does not appear in this section.

Fig. 4. Butluts occitanus. Young with mother. Sagittal. 250:1.

Shows the whole course of the coxal artery $(C A)$ from the artery of appendage $\mathrm{V}$ to the saccule, where it breaks up into the glomus $(G L)$.

( $O$ in brackets) indicates the position of the outlet.

\section{Plate 4.}

Fig. 5. Buthus occitanus. Adult. 200:1.

The glomus $(G L)$ formed at the entrance of the coxal artery into the saccule $(S)$. Compare with $(G L)$ in the young scorpion, photograph 4.

Fig. 5a. Tejovis flavies. Sagittal. $250: 1$.

A part of photograph 1 more highly magnified, showing the coxal artery $(C A)$ entering the saccule $(S)$ and breaking up into the glomus $(\mathrm{G} L)$.

Fig. 5b. Buthus occitanus. Adult. $300: 1$.

From the same specimen as photograph 5 to show the striation of the labyrinth cells under a higher magnification.

\section{Plate 5 .}

Fig. 6. Vejoris flavies. Sagittal. 100:1.

The lymphatic organ $(L O)$ lying in the abdomen and opening through the diaphragm $(D)$ into the capsule of the coxal gland. 
Below the lymphatic organ is the large ventral sinus (VS). The saccule lies more externally and is not visible.

Fig. 6a. Diplocentrus scaber (Scorpionid). Sagittal. 100:1.

Lymphatic organ and coxal labyrinth as in 6 . The ventral sinus is only partially seen.

Plate 6 .

Fig. 6b. Euscorpins italicus (Chactid). Sagittal. 100:1.

Lymphatic organ as in 6. In Euscorpius the lymphatic organ is extensive and somewhat coiled upon itself. One of the large binucleated nephrocytes is clearly seen in the ventral sinus. $(B R)$ is a part of the suboesophageal ganglion.

Fig. 6c. Scorpio maurus (Scorpionid). Young with mother. $100: 1$.

Lymphatic organ and ventral sinus.

\section{Pedipalps.}

\section{Plate 7 .}

Fig. 7. Tarantule palmata. Sagittal. 100:1.

Coxal gland. General view showing the saccule $(S)$, the three divisions of the labyrinth $(C L a, C L m, C L p)$, and the straight return ventral tubule (VTL) leading to the exit tubule (ET) and outlet on appendage III.

Fig. 7a. Tarantula palmata. Sagittal. 100:1.

Coxal gland. Similar view to that of 7 , taken from another specimen. The central lumen of the saccule (CSL) narrowing above to form the collecting tubule, is better shown than in 7 . C.III, C.IV, C. I, are the coeca corresponding to the appendages below.

\section{Plate 8 .}

Fig. 8. Tarantula palmata. Sagittal. $300: 1$.

The exit tubule, more highly magnified.

Fig. 9. Tarantula palmata. Transverse. 250:1.

The saccule with the inhanging glomeruli and central lumen $(C S L)$ with the collecting tubule (CT) leading into the labyrinth $(C L)$.

Below, on the left of the saccule, is the beginning of the exit tubule. The glomeruli can be better distinguished in $9 \mathrm{~b}$. The small spherical nuclei belong to the cells lining the lumina of the saccule. 


\section{Plate 9.}

Fig. 9a. Tarantula palmata. Transverse. 250:1.

Similar view to that of 9 , but taken from another specimen.

Fig. 9b. Tarantula fuscimana. Transverse. $225: 1$.

Similar view to those of 9 , and $9 a$. The cells lining the collecting tubule are peculiar in that the nuclei lie on the free border of the tall cylindrical cells.

This peculiarity is seen best in $9 \mathrm{~b}$. A part of the exit tubule $(E T)$ can be seen below the saccule.

\section{Plate 10.}

Fig. 9c. Tarantula fuscimana. Transverse. $75: 1$.

Compound of two photographs taken from the same specimen eight sections apart, just posterior to appendage III.

The anterior part of the coxal gland with saccule, collecting tubule, exit tubule and anterior division of the labyrinth lies on either side of the enormously developed brain, pierced by the narrow oesophagus.

Fig. 10. Tarantula palmata. Transverse. $400: 1$.

A transverse section across the middle division of the labyrinth to show the cylindrical, slightly basophil cells, and the blood channels running between the tubules.

Fig. 11. Tarantula palmata. Transverse. $100: 1$.

A transverse section taken near the middle of the coxal gland to show the relation of the labyrinth $(C L)$ to the ventral sinus $(V S)$ and the straight return ventral tubule (VTL). The ventral sinus lies close to the endosternite, internal to the ventral tubule. From the sinus blood channels run between the coils of the labyrinth.

\section{Plate 11.}

Fig. 12. Tarantula fuscimana. Sagittal. 100:1.

The coxal labyrinth with its three divisions lying dorsal to the large ventral sinus $(V S)$. Below the sinus is the endosternite $(E N D)$. The basophil cylindrical cells of $C L m$ can be clearly distinguished from those of $C^{\prime} L p$ and $C L a$.

Fig. 12a. Tarantula palmata. Sagittal. 100:1.

Similar view to that shown in 11 .

The cells of CLm are clearly columnar but not so basophil as is usual. Compare with $7 \mathrm{a}$ from the same specimen. 11 and $11 \mathrm{a}$ are taken from sections lying more internally than 7 and $7 \mathrm{a}$. The saccule and ventral tubule lie externally and are not seen. 


\section{Theraphosid spiders.}

Plate 12.

Fig. 13. Hapalopus pentaloris. Immature. Frontal. $30: 1$.

The coxal labyrinth of one side, lying along the long axis of the cephalothorax from appendage III, to the posterior aspect of appendage VI. Section at about the middle of the cephalothorax. On the right $\left(C L^{\prime}\right)$ is a small part of the coxal gland of the opposite side.

Fig. 13a. Hapalopus pentaloris. Immature. Frontal. 30:1.

A section from the same specimen as 13 , taken more ventrally. The coxal labyrinth is now broken up into four parts, each of which represents a dip on the posterior aspect of an appendage. (C) are the coeca of each appendage, and between the coeca and the coxal labyrinth of appendages III and $V$, the saccules can be seen, though not very clearly on account of the low magnification.

On the right of the endosternite (END) are $(O E)$ the position of the oesophagus $(S T)$, a dilatation between the oesophagus and sucking stomach $(S C /)$. The section is folded over at $(S C h)$ so that the lumen of the sucking stomach is obscured, but its lateral muscles and their relation with the endosternite $(E N D)$ can be seen.

\section{Plate 13.}

Fig. 14. Avicularia. Cocoon. Transverse. 250:1.

Showing the $\operatorname{dip}(D V I)$ of the coxal labyrinth almost to the external surface $\left(E_{4} \mathrm{Y} T\right)$ on appendage VI. There is however no actual outlet. $(C V I)$ is the coecum of appendage VI. $(B L S)$ is a blood sinus.

Fig. 15. Eurypelma ragans. Cocoon. Sagittal. 225:1.

Coxal gland on appendage III, showing the saccule $(S)$, the collecting tubule $(C T)$ entering the labyrinth $(C L)$ and finally the exit tubule with its outlet behind appendage III. [The glomeruli $(G L R)$ can be distinguished from the lobular windings of the saccule by the absence of the small spherical nuclei which belong to the lining cells of the saccule.] At $C L^{1}$ on the right of the photograph the labyrinth extends posteriorly along the length of the cephalothorax (compare photo 13).

\section{Plate 14.}

Fig. 15a. Eurypelma vagans. Young with mother. Sagittal. 250:1. Coxal gland on appendage III. Similar view to that of 15 . A portion of the collecting tubule can be clearly distinguished, but it is cut off from the main part of the saccule. At $C L^{1}$ the labyrinth continnes posteriorly as in 15 . 
Fig. 15b. Hapalopus pentaloris. Immature. Frontal. 250:1.

Coxal gland on appendage III, A portion of the saccule with its central lumen $(C S L)$, and collecting tubule $(C T)$ leading to the labyrinth $(C L)$.

\section{Plate 15.}

Fig. 16. Ischinocolus. Transverse. 250:1.

Coxal gland on appendage $\mathrm{V}$.

A portion of the saccule with its central lumen (CSL) and the collecting tubule $(C T)$ leading to the labyrintl $(C L)$.

Fig. 16a. Hapalopus pentaloris. Immature. Frontal. 250:1.

Coxal gland on appendage V. From the same specimen as 15b. The arrangement is precisely the same, but in $16 \mathrm{a}$ is on appendage $\mathrm{V}$, and in $15 \mathrm{~b}$ on appendage III.

\section{Plate 16.}

Fig. 16b. Eurypelma vagans. Young with mother. Frontal. 250:1.

Coxal gland on appendage $\mathrm{V}$, with saccule, collecting tubule and labyrinth all communicating.

Fig. 17. Avicularia. Adult. Sagittal. 100:1.

Exit tubule and outlet on appendage III.

\section{Plate 17 .}

Fig. 17a. Avicularia. Cocoon. Sagittal. 250:1.

Exit tubule and outlet on appendage III. (CIII) Coecum of appendage III.

Fig. 18. Avicularia. Cocoon. Transverse. 250:1.

Exit tubule and outlet on appendage $\mathrm{V}$. ( $(\mathrm{V})$ ) Coecum of appendage $\mathrm{V}$.

\section{Plate 18.}

Fig. 18a. Hapalopus pentaloris. Immature. Transverse. 250:1. Exit tubule on appendage $\mathrm{T}$.

Fig. 18b. Eurypelma ragans. Cocoon. Sagittal. 250:1.

Exit tubule and outlet on appendage $\mathrm{V}$.

\section{Plate 19.}

Fig. 18c. Theraphosid from Biskra. Young. Transverse. 250:1.

Exit tubule on appendage $V$, with portions of the labyrinth $(C L)$ and saccule $(S)$. Just before the exit tubule is reached there is a vesicular swelling $(V)$.

Fig. 19. Isclenothele. Immature. Sagittal. 250:1.

Coxal gland. The saccule $(S)$ changes at $(C T)$ into the long straight tubule of the labyrinth running posteriorly and corre- 
sponding to the external tubule in the Dysderids. The interual wall of the tubule is irregular in outline and the tubule seems to have been formed by a breaking through of adjacent labyrinth coils. The return tubule $(R T)$ running forward to the exit lies partly above and partly below, and corresponds to the interual or return tubule of the Dysderids and hunting spiders. It also is irregular in outline. The approximate position of the exit tubule is indicated by $(E T)$ in brackets.

\section{Plate 20.}

Fig. 20. Dugesiella hentzii. Adult. 400:1.

A portion of the coxal gland three days after inoculation with carmine. The lining cells of the saccule are swollen, and are filled with minute granules. The nuclei are stained witl hematoxylin and there is a counterstain of orange, but the granules in the cells represent the red carmine granules. No such granules can be seen in the labyrinth cells.

\section{Arameae verae.}

\section{Group 1.}

Fig. 21. Loxosecles mefescens (Sicariid). Adult. Trans. 200: 1.

Transverse section at about the middle of the coxal gland. LET is the external tubule leading posteriorly from the saccule, and LIT the internal tubule, close to the endosternite, leading anteriorly towards the exit tubule. The cell surfaces are worn down to the nuclei but the striation shows no evidence of deterioration.

\section{Plate 21.}

Fig. 22. Dysder $(s p$. ?) (Dysderid). Immature. Trans. 400: 1.

Transverse section about the middle of the coxal gland. Compare with 21.

Fig. 23. Dysdera crocata. Adult. Trans. 250: 1.

Transverse section across the coxal gland at the point where the saccule $(S)$ passes into the exterual tubule (LET).

Fig. 24. Loxosceles mesescens. Adult. Trans 250:1.

Transverse section across the anterior part of the coxal gland, showing the saccule and interual tubule $(G L R)$ is a large glomerulus with a mass of blood cells. The nuclei of the blood cells are oval or flattened; those of the saccule are spherical. The diagram explains better than a description how it comes about that the internal tubule of the labyrinth appears to be double. 


\section{Group 2. \\ Plate 22.}

Fig. 25. Selenops mexicanus (Selenopid). Adult. Sagittal. 250:1. Showing the saccule $(S)$ passing into the external tubule (LET), the walls of which are thinned down, and the cells, flattened so as to resemble those of the saccule. At $C h$ the lining epithelium of the external tubule changes to that of the internal tubule, the subsequent (internal) course of which is then roughly indicated by the broken lines until it reaches LIT, which then leads to ET, the beginning of the exit tubule. The internal tubnle retains some traces of striation, but in most members of this group the striation is entirely lost.

Fig. 25a. Lycosa radiata. Adult. Sagittal. $100: 1$.

A view of the coxal gland comparable with that of photo 25 . There is an extension of the internal tubule (LIT) over appendage III, which ends blindly a little further anteriorly. The position of the exit tubule and outlet are indicated in brackets.

Plate 23.

Fig. 26. Lycosa radiata (Lycosid). Adult. Sagittal. $40: 1$.

The coxal labyrinth $(C L)$ is here converted into a large vesicle. The exit tubule and ontlet are clearly shown, but the saccule does not appear in this section.

(C) Coecum of appendage III. (BlS) Blood sinus.

Fig. 27. Tegenaria domestica (Agelinid). Adult. Sagittal. 100:1.

A view comparable to that of 26 .

(CIII) Coecum of appendage III. (NIII) Nerve of appendage III.

Fig. 28. Zodariid Spider (Sp.?). Sagittal. $250: 1$.

Showing the external tubule ( $L E T)$ changing to the internal $(L I T)$. In this case the external tubule has become so much fused with the saccule that it is impossible to distinguish between them, except at the point of change.

\section{Group 3.}

Plate 24.

Fig. 29, 29a, 29b. Filistata hibernalis (Filistatid). Adult. Sagittal.

Three sagittal sections of the coxal gland, from the same specimen, taken at different points.

The thin walled external and internal tubules of the labyrinth have become so fused with the saccule that it is impossible to distinguish between them. In these sections the glomeruli are 
filled with granular matter; the lobes of the saccule appearing to be empty.

Fig. 29. From a section through a more external part of the gland.

The short vesicle $(V)$ opens above into the saccule $(S)$ with its inhanging glomeruli $(G L R)$. Below the exit tubule is indicated by ( $E^{\prime} T$ in brackets).

Probably that part of the saccule into which the vesicle opens, represents the remains of the internal tubule, the true saccule being that part which lies on the right, immediately below the coecum.

Fig. 29a. From a section a little more internal to 29. 100:1.

A small portion of the vesicle can still be seen opening widely into the saccule. The saccule itself now extends posteriorly for a considerable distance, its posterior portion being probably chiefly if not entirely composed of what were originally the tubules of the labyrinth.

Plate 25.

Fig. 29b. From a section still more internal. 100:1.

Showing the relation of the saccule to the endosternite. Probably all of the saccule here visible represents the original labyrinth tubules, since the saccule itself in the Theraphosids and in group 1 of the Araneae verae does not extend so far internally.

(CIII, CIV) Coeca of appendages. Each coecum loops round over and external to the coxal gland and enters the appendage. $(P)$ Loops of the poison gland which in Filistate is very extensive. $(B L S)$ Blood sinus from which glomeruli hang into the saccule.

Fig. 30. Latrodectus mactans (Theridiid). Adult. Sagittal. 250:1.

Views comparable with that of 29 , but showing in addition the exit tubule $(E T)$ and outlet $(O)$. The walls of the vesicle are here surrounded by finely striated longitudinal muscles.

Plate 26.

Fig. 30a see Fig. 30 .

Fig. 31. Epcira trifolium (Epeirid). Adult. Sagittal. 100:1.

May be compared with photograph 30 . The vesicle is filled with excretory products.

Fig. 32. Theridium tepidarionum ('Theridiid). Adult. Sagittal. $100: 1$.

The details of the saccule are not well shown, but the vesicle, opening widely into it and the exit tubule are clearly marked. 


\section{Part II. Tracheate Arachnids and Peripatus.}

\author{
$B$ Bulge into saccule \\ C Coeca of intestinal tract \\ $C L$ Coxal labyrinth \\ CSL Central lumen of saccule \\ CT Collecting tubule \\ $D S L$ Diverticulum of labyrinth sac \\ EP Epidermis \\ ET Exit tubule \\ FO Final outlet \\ $G N$ Ganglion \\ II Heart \\ $I N^{\top} T$ Intestine \\ KS Sucking chamber \\ L.II Nodified part of labyrinth \\ $L R$ Sheath \\ II Muscles
}

IIS Muscles of saccule

$N$ Nerve

NII Modified nephridium

$N Z$ Nozzle

$O$ Outlet

$R$ Rostrum

$S$ Saccule

$S A L$ Salivary gland

$S L$ Labyrinth sac

SlG Slime gland

SO Side outlet

$T R$ Trachea

TRS Tracheal stigmata

$T^{\top}$ Vesicle

V.YC Ventral nerve cord

\section{Solifugae.}

\section{Plate 27.}

Fig. 33. Paragaleodes baibarus. Oblique. 250:1.

Showing the finely striated muscle fibres $(M S)$ attached to the periphery of the saccule $(S)$.

Fig. 34. Paragaleodes scalaris. Oblique. $225: 1$.

Saccule with central lumen $(C S L)$ and muscle fibres radiating out from the periphery.

\section{Plate 28.}

Fig. 34a. Solpuga flarescens. Sagittal. $250: 1$.

Saccule with central lumen and radiating muscle fibres, much finer than the ordinary somatic muscles $(M)$.

The tissue of the saccule is more compact than in 34 , and the saccule is more closely surrounded by somatic muscles.

Fig. 34b. Galcoles arabs. Transverse. 250:1.

Saccule with lumen. The tissues are more compact than in 34 , or $34 a$, and the short muscles radiating from the saccule are arranged in bundles.

Plate 29.

Fig. 35. Ammotrecha (Alc. sp. M.). Transverse. $200: 1$.

Showing the whole course of the collecting tubule $(C T)$ from the saccule $(S)$ to the labyrinth sac $(S L)$. 
Fig. 36. Daesina (sp.?). Transverse. $300: 1$.

To show the abrupt change from the labyrinth sac ( $S L)$ with its columnar secretory epithelium, to the excretory cells of the labyrinth tubule with striated border on which the minute nuclei rest.

Fig. 36a. Paragaleodes scalaris. Transverse. 300:1.

Change from labyrinth sac to striated tubules in another specimen.

\section{Plate 30.}

Fig. 37. Paragaleodes scalaris. Frontal. 100:1.

Labyrinth sac $(S L)$ to show the pouching. The labyrinth sac is lined with tall columnar epithelium, but there are no products of secretion in the lumen.

Fig. 37a. Paragaleodes larbarus. Frontal. $100: 1$.

Labyrinth sac $(S L)$ to show the pouching. The lumen of the sac is filled with products of secretion, and the cells are worn down almost to the nuclei. At $(C T)$ is the entrance of the collecting tubule.

Plate 31.

Fig. 38. Paragaleodes barbarus. Oblique. 250:1.

Exit tubule $(E T)$, with muscular walls, running anteriorly just below the integument of appendage II, and leading to the nozzle ( $N Z)$, which opens into $(L R)$ the commencement of the sheath. It seems as if the secretory products had just been squirted out; some traces (. Sp.?) still remaining in the expanded orifice of the nozzle.

Fig. 3Sa. Paragaleodes barbarus. Sagittal. 250:1.

View similar to that of 38 , in another specimen. The nozzle is here cut through a little to one side of its orifice.

\section{Plate 32.}

Fig. 38b. Solpuga flarescens. Frontal. 250:1.

View similar to that of 38 and $38 a$, but showing a dilation the exit tubule.

Fig. 39. Fialeodes (? Othoes). Frontal. 100:1.

$(R)$ is near the opening of the rostrum to the exterior. $(K S)$ is the sucking chamber of the rostrum, passing posteriorly into the oesophagus which lies between the two lobes of the brain (BR). Above, on the right, the position of the nozzle $\left(N_{i}\right.$ in brackets) is indicated, anterior to which is the sheath $(L R)$. 
In this species the sheath is converted into a definite tubule which runs a little further inwards than is shown in the photograph; the final outlet being approximately in the position indicated by ( $F O$ in brackets) but the tubule does not project beyond the appendage as in 40 and $40 \mathrm{a}$. It can be readily seen that $(L R)$ is directed towards the opening of the rostrum.

\section{Plate 33.}

Fig. 40 and 40a. Solpuga flarescens. Sagittal. 250:1.

In 40 the exit tubule and nozzle are seen below, and above is a part of the sheath $(L R) .40 \mathrm{a}$ is taken from the same specimen two sections further on. The position of the nozzle is indicated by $(N Z)$ in brackets, above which a longitudinal section of the sheath can be seen, at first running along the appendage, and then projecting beyond it from the point where the appendage turns outwards, i. e. to the left in the photographs. The approximate position of the final outlet is indicated by $(F O)$ in brackets, and that of the side outlet by $(S O)$ in brackets.

\section{Plate 34.}

Fig. 41. Paragaleodes barbarus. Frontal. 100:1.

Main part of the coxal gland. Above (anteriorly) is the saccule $(S)$ with its central lumen (CSL) passing into the collecting tubule $(C T)$, surrounded by pouches of the labyrinth sac $(S L)$. Below can be seen the abrupt change from the labyrinth sac to the excretory tubule $(C L)$ with its striated cells. The course of the collecting tubule can be followed through several sections to its entrance into the labyrinth sac, shown in photo $37 \mathrm{a}$, taken from the same specimen.

Fig. 41a. Parayaleodes barbarus. Frontal. 250:1.

A part of the same field as 41 , more highly magnified, to show the collecting tubule and its surroundings more in detail.

( $B$ in brackets) corresponds to the bulge on the other side. See photo 42 (B).

\section{Plate 35.}

Fig. 42. Paragaleodes barbarus. Frontal. 100:1.

Similar view to that of $4 \mathrm{l}$ taken from the other side of the same specimen. The collecting tubule is closed by a bulge $(B)$ from the labyriuth sac, which protrudes also into the lumen of the saccule. Just below the bulge is the change from the labyrinth sac to the excretory tubule of the labyrinth. By comparing 42 with 41 it can be seen how very closely the parts correspond on either side. 
Fig. 42a. Paragaleodes barbarus. Frontal. 250:1.

Taken from the same specimen as 42 , two sections further on, showing the bulge, more highly magnified, protruding into the lumen of the saccule.

\section{Plate 36.}

Fig. 43. Solpuga flavescens. Transverse. 100:1.

Taken near the posterior end of the labyrinth coils, about opposite appendage $\mathrm{V}$, showing the complicated coils of the tubules, some of which belong to the right side and some to the left side, $C$ is the coecum which runs from the intestine (INT) into appendage $\mathrm{V}(H)$ Heart. ( $(\mathrm{I})$ Ventral nerves.

Fig. 44. Eremobates (Alc. sp. M.). Transverse. 100:1.

$R$ is the rostrum with its sucking chamber (KS), on the left of which is the coxal joint of appendage II. On the dorsal aspect of appendage II is the sheath $(L R)$, cut transversely just anterior to the nozzle, with its side outlet $(S O)$ turned away from the rostrum.

Just in front of this point the sheath closes up again, and passes anteriorly as in photographs 40 and $40 \mathrm{a}$.

$I$ is the chelicera which works above the coxa of appendage II.

\section{Plate 37.}

Fig. 45. Galeodes (? Othoes). Frontal. 250:1.

A section showing the collecting tubule (CT) which is here lined with columnar epithelium resembling that of the labyrinth sac, so that the collecting tubule appears lost as a separate entity. Its position however, between two pouches of the labyrinth sac is the same as usual. In this specimen the columnar cells lining the labyrinth sac are much more regular than is usual. In the excretory part of the labyrinth $(C L)$, the columnar character of the cells is maintained, but the nuclei are raised and rest upon the striated base.

Fig. 46. A compound of photos 40 and 42. Frontal. 40:1.

The photographs are taken 12 sections apart. Each section $12 \mu$ thick. The two sections taken together show the relations of the coxal glands on either side to each other and to the surrounding tissues. On one side is seen the open collecting tubule, but on the other side the tubule is clased by a bulge from the labyrinth sac. For the finer details see photos 41, 41a, 42, 42a. 
Plate 38.

Fig. 47. Peripatus nicaraguensis. Adult. Frontal. 250:1.

Typical nephridium near posterior end of body. The long collecting tubule (CT) with ciliated cells leading out of the saccule $(S)$. The labyrinth $(C L)$ changing to the modified part $(L M)$ is seen on the right of the collecting tubule.

Fig. 47a. Peripatus juliformis. Adult. Transverse. 250:1.

Typical nephridium near anterior end of body with saccule, collecting tubule, labyrinth changing to modified part, and the vesicle $(V)$. Above on the right is the labyrinth sac of the salivary gland $(S L)$. (EP) Epidermis. $\left(G N^{\top}\right)$ Ganglion.

\section{Plate 39.}

Fig. 47b. Peripatus nicaraguensis. Adult. Transverse. 250:1.

Typical nephridium. The bascphil granules in the cells of the modified part of the labyrinth are clearly shown.

Fig. 47c and 47d. Peripatus juliformis. Sagittal. 400:1.

Showing the change from the labylinth to its modified part under higher magnification.

Diagram 3 may be consulted in connection with photographs 47 to $47 \mathrm{~b}$, in order to understand how $(C T)$ and $(L M)$ lie closely apposed without however having any direct connection with each other.

Fig. 48. Peripatus jamaicensis. Adult. Sagittal. 100:1.

Salivary gland showing the saccule, collecting tubule and diverticulum which joins the labyrinth sac a little further posteriorly. $(T N C)$ is the ventral nerve chain. $(C L R)$ the striated part (reservoir) of the gland which runs posteriorly under the nerve chain to the eighth leg. The basophil granules of $(D S L)$ are stained very dark with hematoxylin, without resolution of the individual granules.

\section{Plate 40.}

Fig. 49. Peripatus juliformis. Transverse. $250: 1$.

Modified small nephridium of appendage III. (First leg), which has lost all its striated, excretory cells. The whole of the nephridium is shown (NMIIII). Above the modified nephridium is a part of the salivary gland, showing the saccule. diverticulum $(D S L)$ with basophil granules and labyrinth sac $(S L)$ with columnar epithelium, cut transversely. $(C L R)$ is a part of the reservoir (BOUvIER) of the salivary gland. 
Fig. 50. Peripatus micaraguensis. Sagittal. 250:1.

Salivary gland showing the saccule $(S)$, the collecting tubule $(C T)$ leading into the diverticulum $(I S L)$ of the labyrinth sac. The diverticulum opens into the main part of the labyrinth sac a little further back. (See photograph 51.) The lining cells of the diverticulum are filled with coarse basophil granules (Compare with those of photo $47 \mathrm{~b}$ ) and in the labyrinth sac itself $(S L)$ the nuclei lie at the base of the tall columnar cells containing globules of secretion, but the lumen of the sac is free from secretion and the cells are intact. Compare with photograph 37 of Paragaleodes. (CLR) is a part of the reservoir which runs posteriorly as far as the third leg.

\section{Plate 41.}

Fig. 50a. Peripatus jamaicensis. Adult. Sagittal. 250:1.

Salivary gland. The specimen had simply been preserved in formol so that the tissues are somewhat swollen and distorted, but the relations of the various parts can be clearly seen and compared with 50 and 48.

The dark mass $(S l G$ ) is the slime gland of the oral papilla filled with mucinous secretion.

Fig. 50b. Peripatus nicaraguensis. Embryo. Sagittal. 250:1.

Salivary gland of developing embryo in the uterus of the specimen photograph 50. (S/G) is the slime gland.

Diagram $F$ may be consulted in connection with photograpks 50 to $50 \mathrm{~b}$.

\section{Plate 42.}

Fig. 51. Peripatus nicaraguensis. Adult. Sagittal. 100:1.

Salivary gland showing the passage of the diverticulum (I)SL) into the main body of the labyrinth sac of the salivary gland $(\$ L)$. Taken from the same specimen as photograph 50 a few sections further on. The basophil granules of the diverticulum suddenly cease where it enters the main sac. Along the dorsal margin of the main sac the secretion appears to be beginning to pour out into the lumen.

Fig. 52. Peripatus juliformis. Adult. Sagittal. 100:1.

Salivary gland. Labyrinth sac in sagittal section to show the incipient pouching and the lumen filled with products of secretion.

Compare with photograph 37 a of Peragalcodes.

$$
\text { Plate } 43 .
$$

Fig. 53. Peripatus juliformis. Adult. Transverse. 250: ].

Salivary gland. Change from the secretory labyrinth sac (. L to the striated part of the gland. At $(C L I i)$ is the beginning of the reservoir. (CL) runs anteriorly to the outlet. 
Fig. 54, 54a, 54b. Peripatus nicaraguensis. $400 \vdots 1$.

All taken from the same specimen to show the similarity of the basophil (hematoxylin) granules in the secretory cells.

Fig. 54. Diverticulum of salivary gland. DSL of previous photographs.

Fig. 54a. Modified part of typical nephridium. $L M$ of previous photographs.

Fig. 54b. Small modified nephridium of appendage 31 .

The collectiug tubule passing directly into a short secretory tubule, corresponding to the part $L M I$ of the typical nephridium. The short secretory tubule passes directly into the exit tubule.

Compare with photograph $49(N M)$. 
Zoolog. Jahrbücher Suppl. 14.

$1 a$

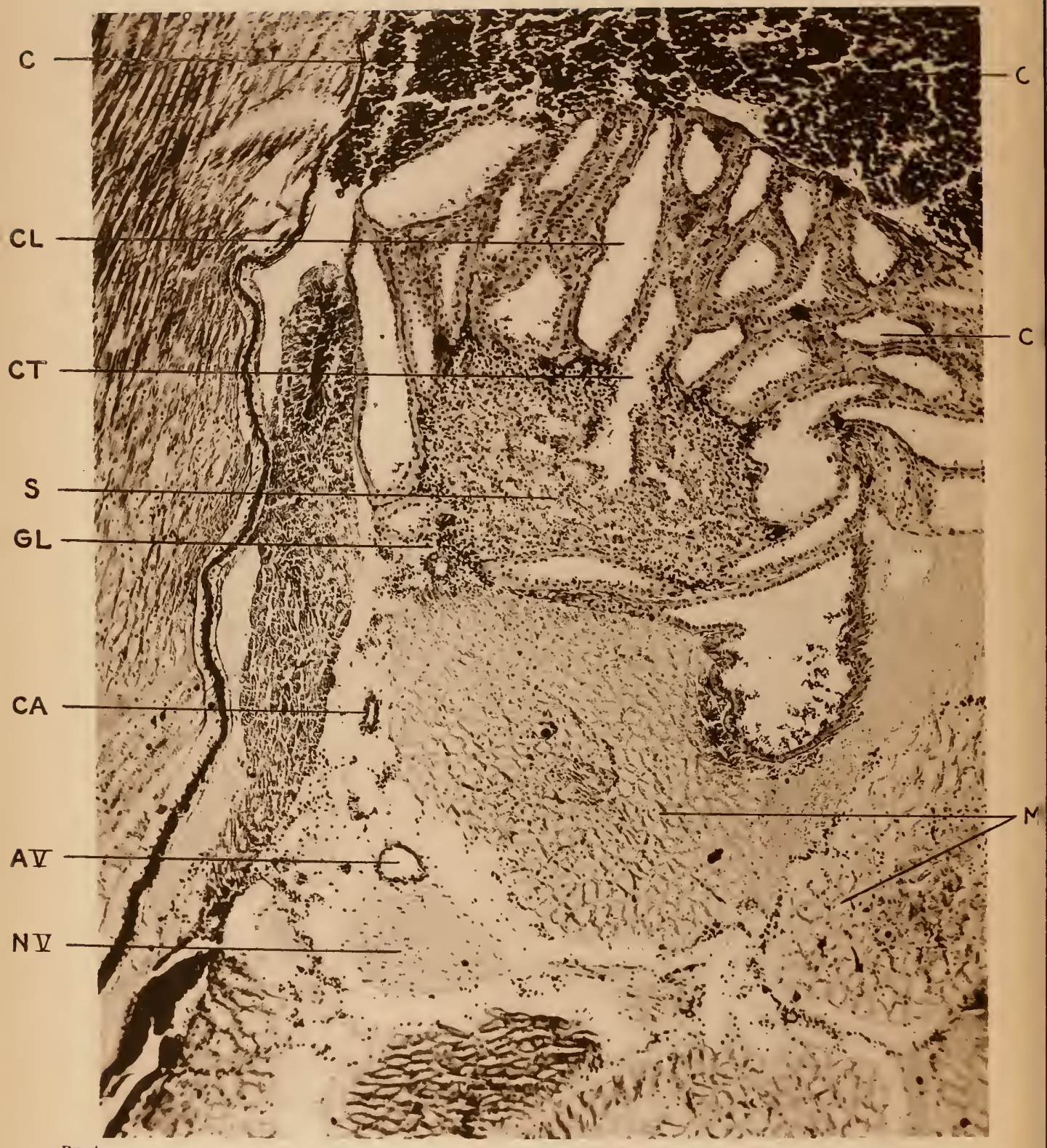

Buxton.

Verlag von Gustav $\mathbf{F}$ 


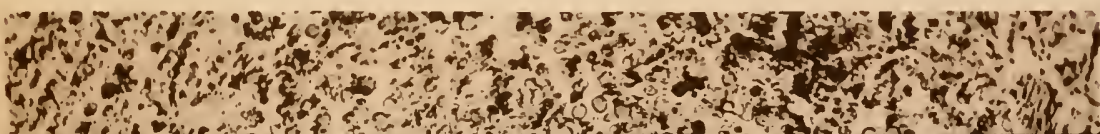

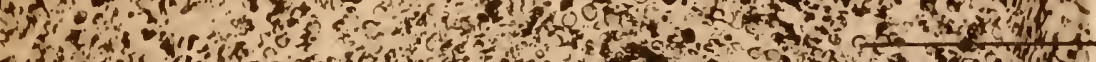

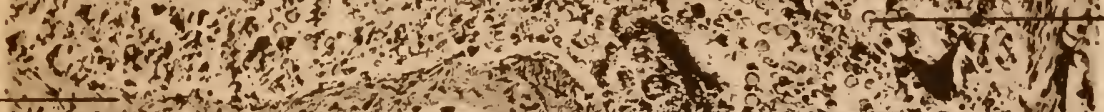

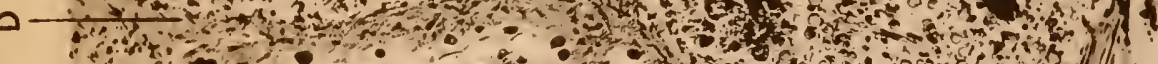

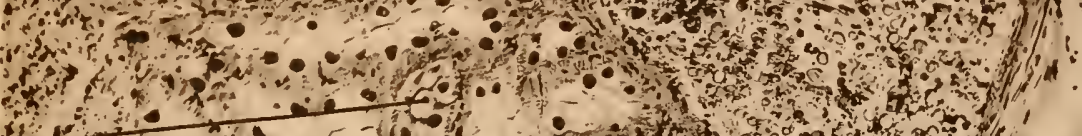

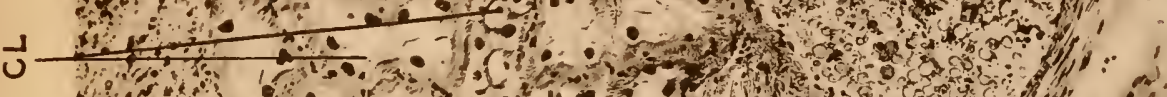

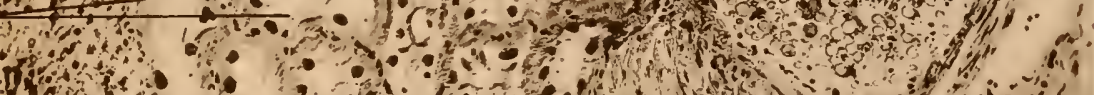

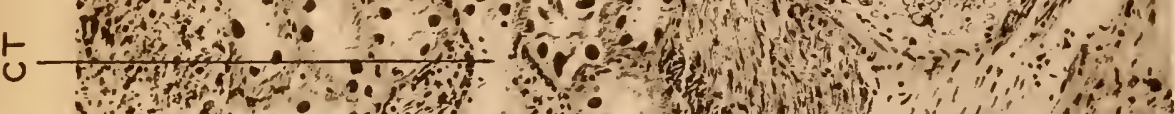
(n)

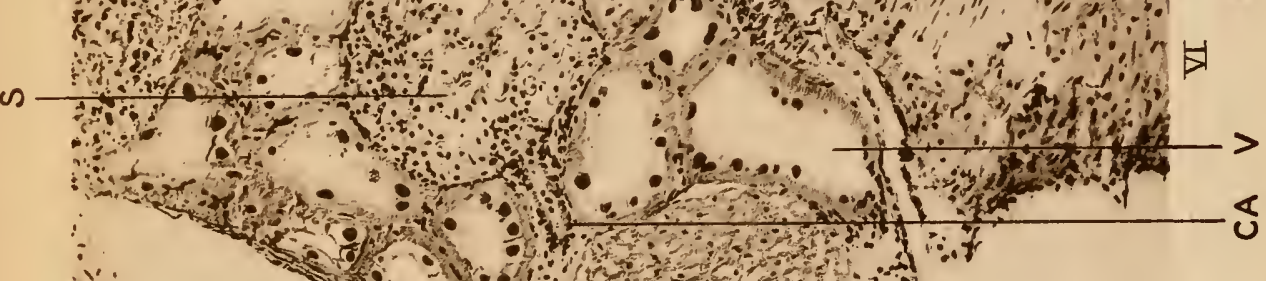

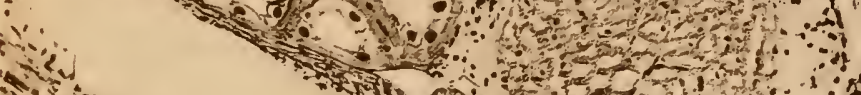

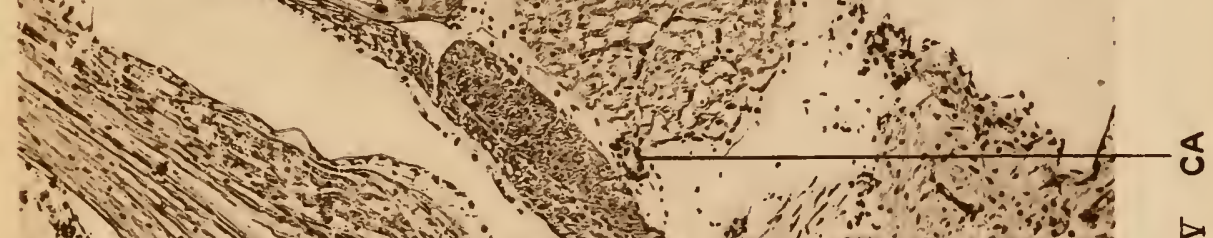

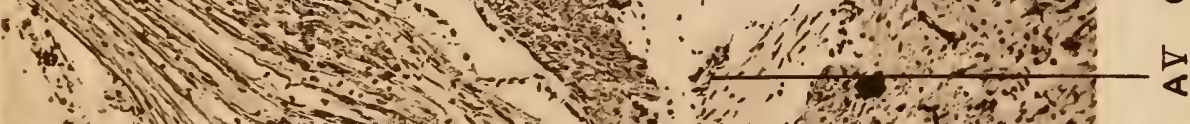

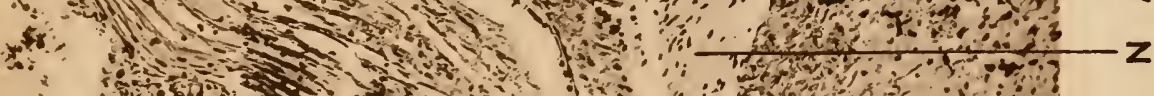
50 -

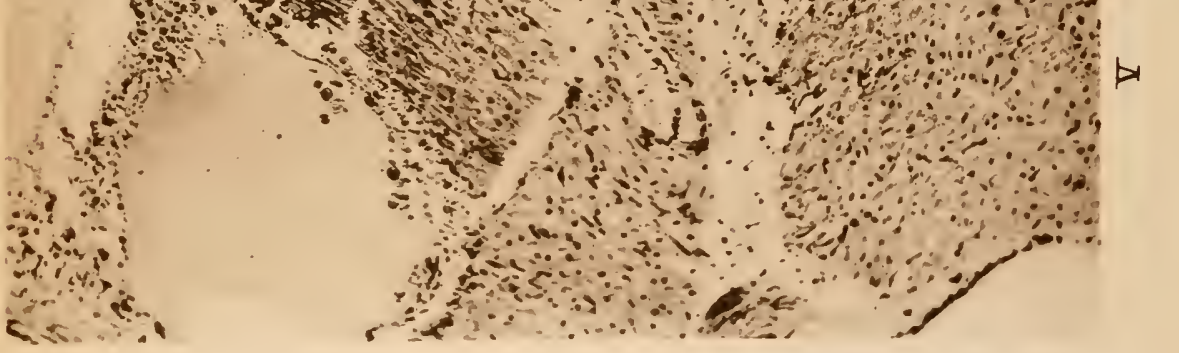

J. B. Obernetter, Mtänchen, reprod.

her in Jena. 




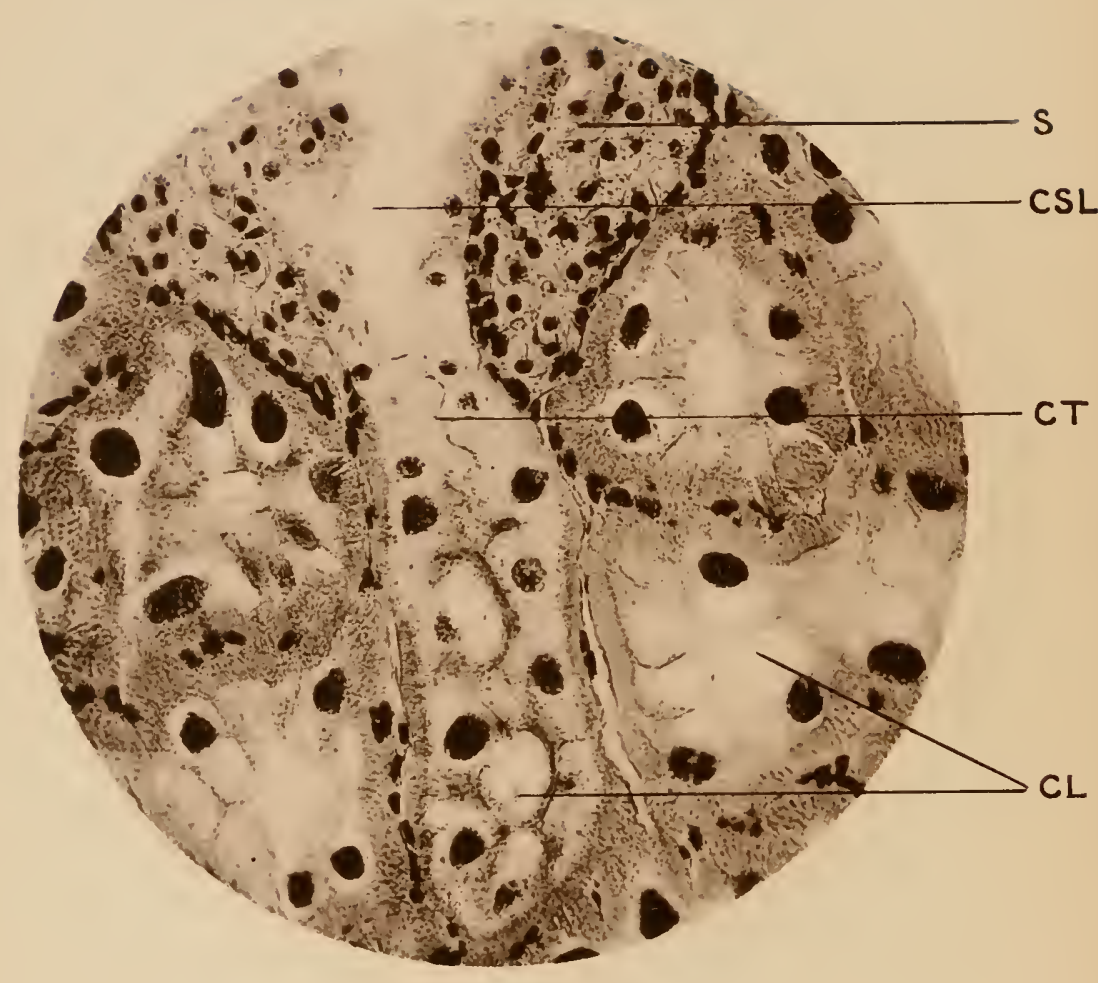

Buxton 
Taf. 2.

$1 c$

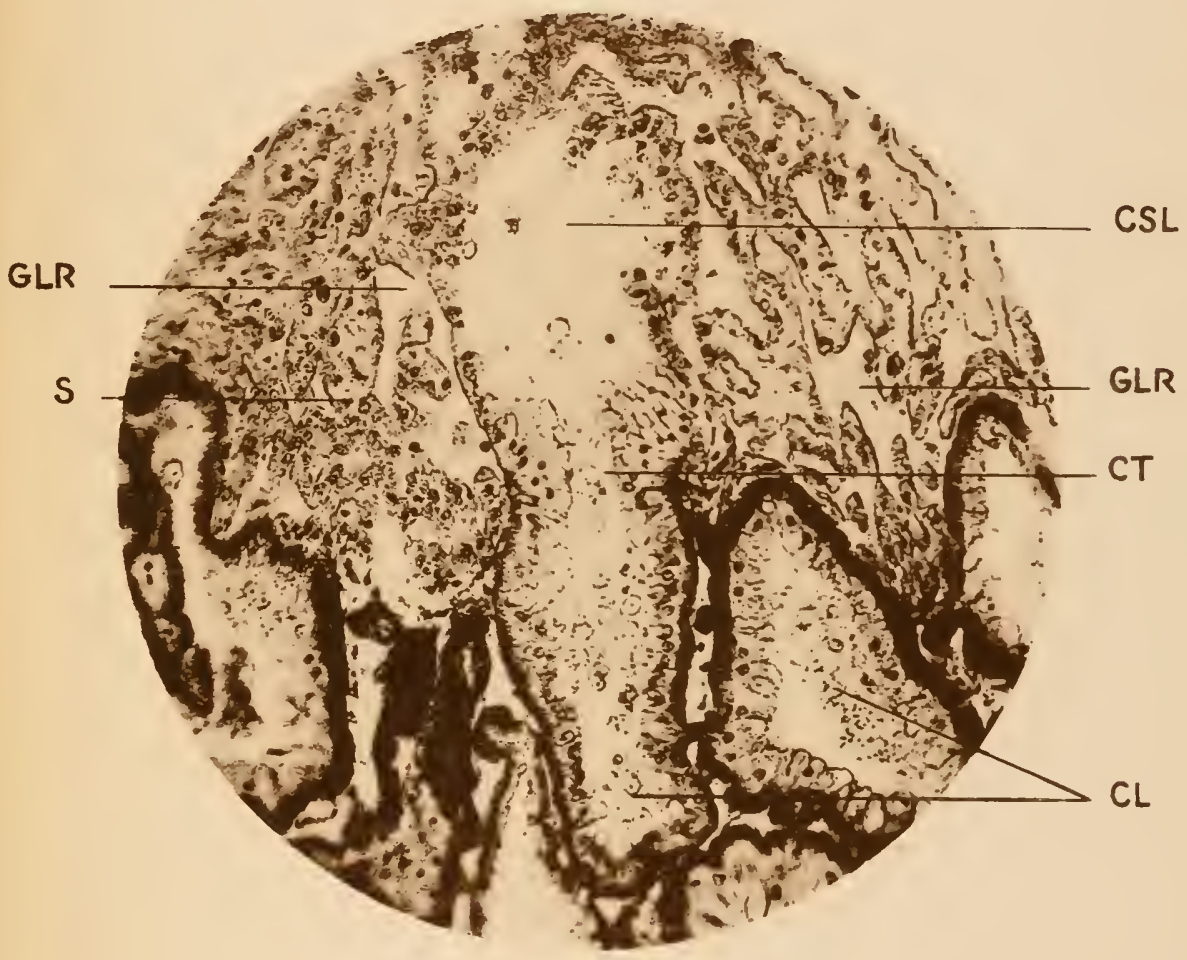

J. B. Obernetter, Mänchen, reprod.

ischer in Jena. 


Zoolog. Jahrbücher Suppl. 14.

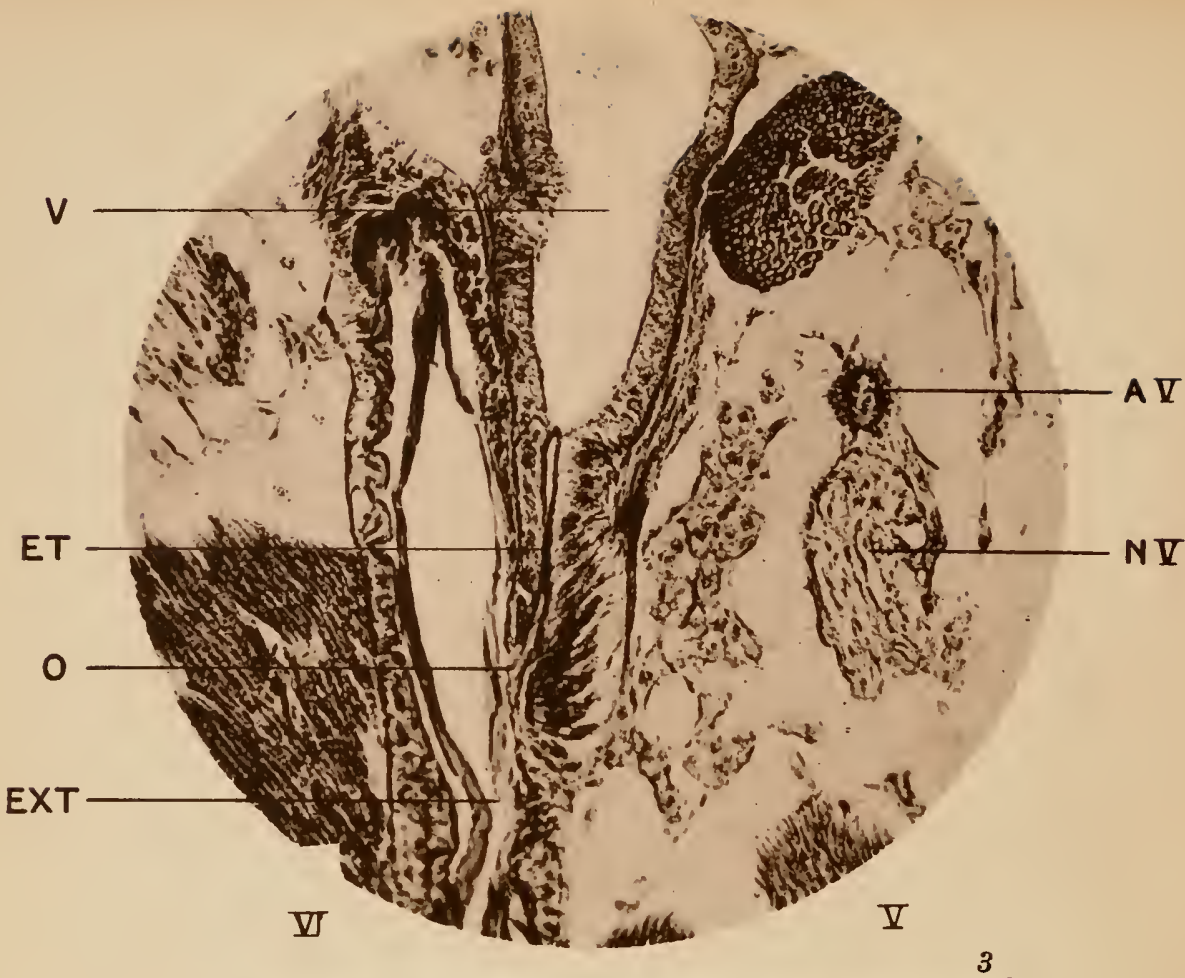

C

ᄃ

$\mathrm{Cl}$

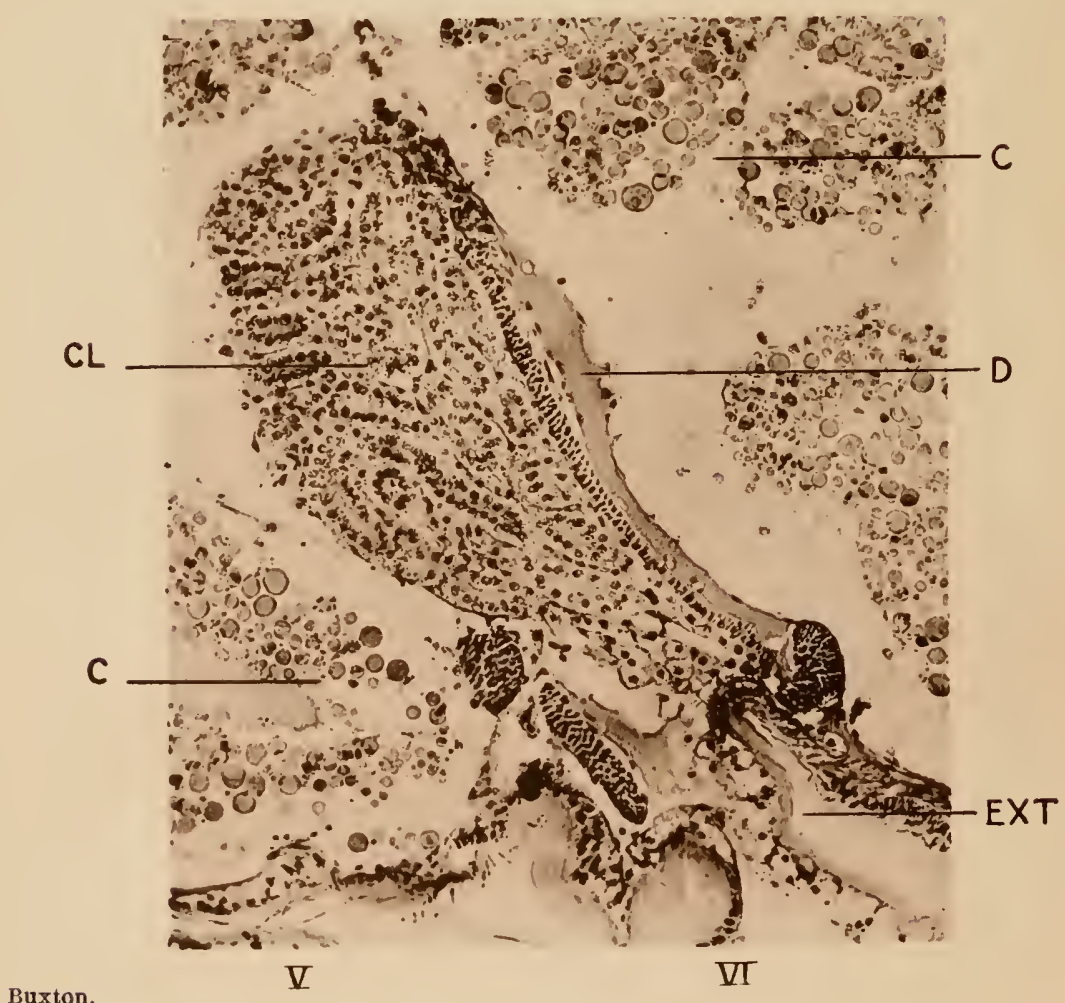





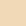


Zoolog. Jahrbücher Suppl. 14.

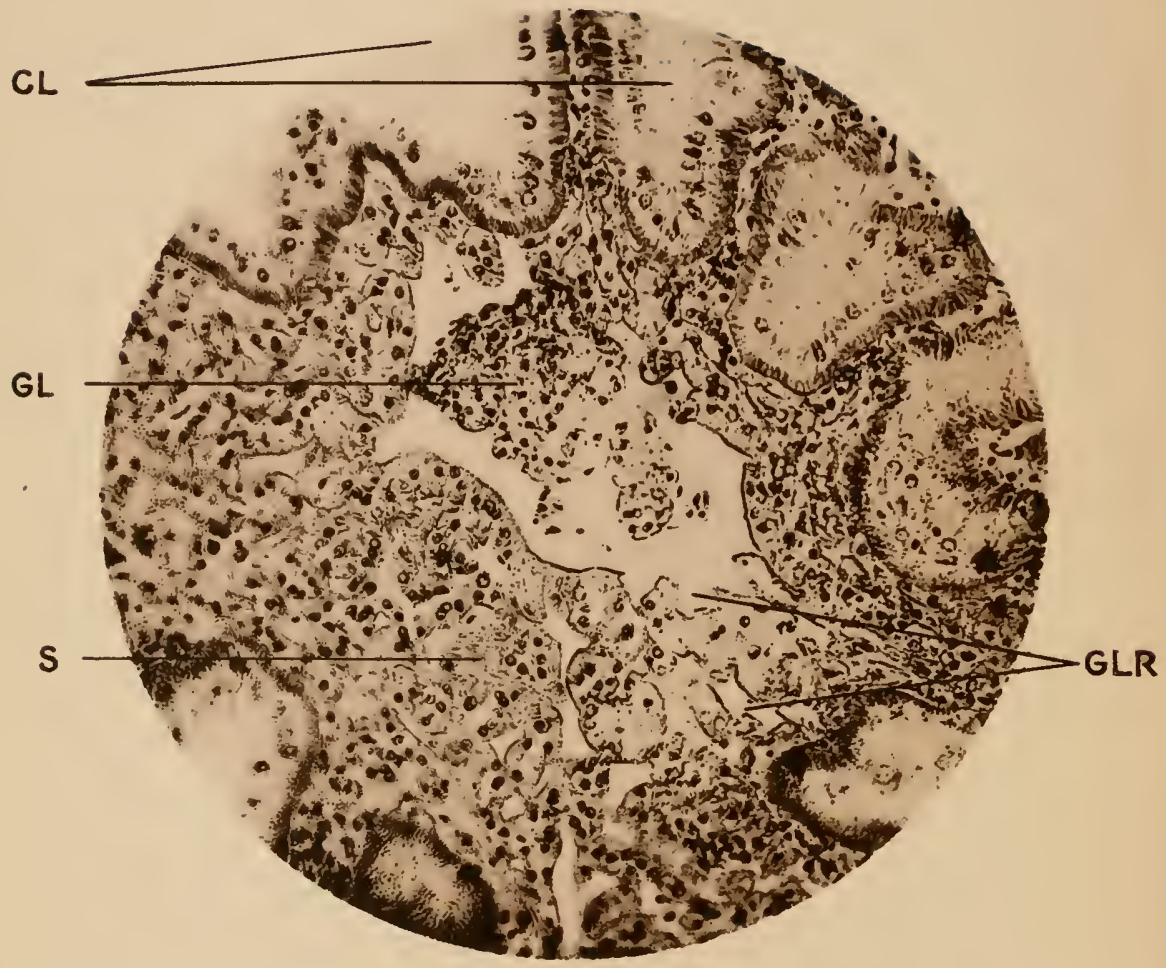

Buxton. 


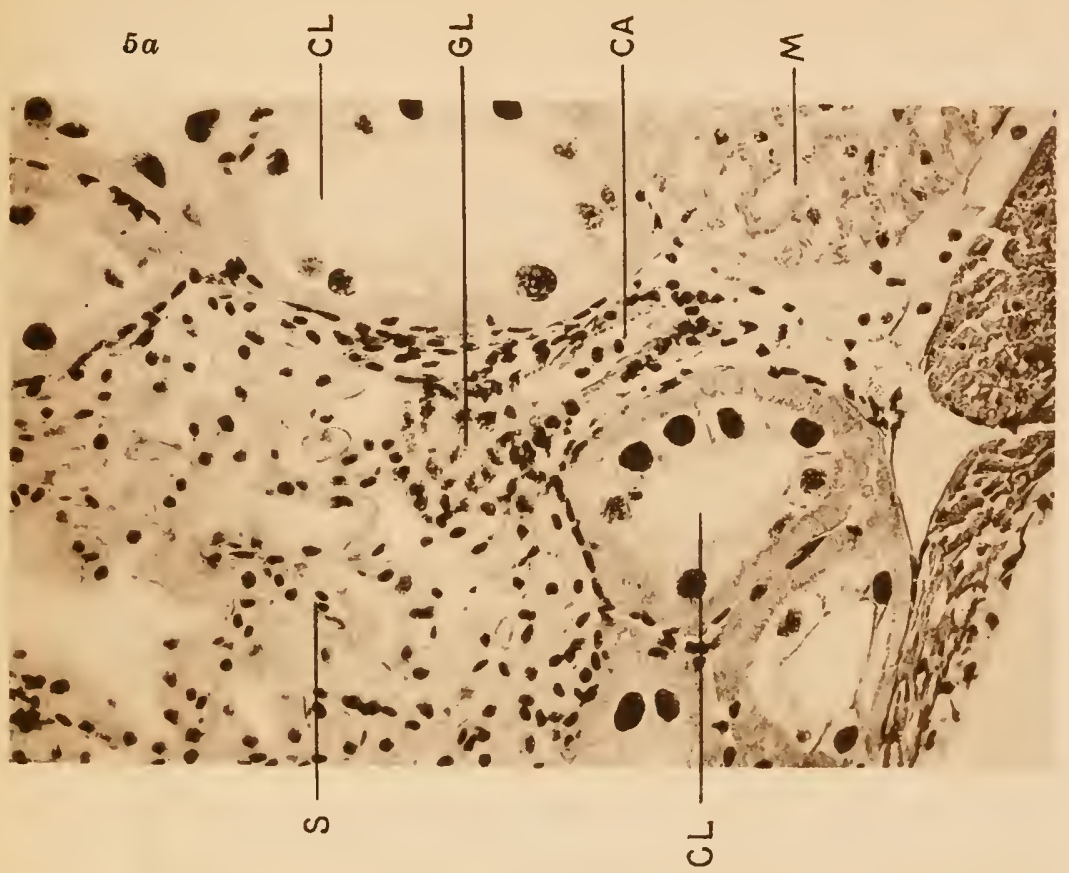

$5 b$

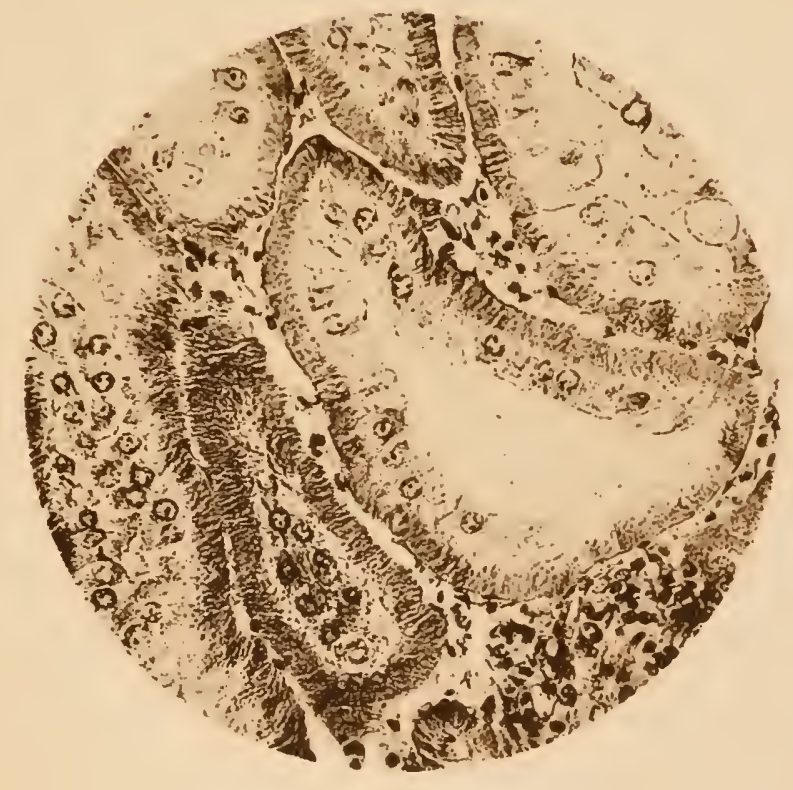

J. B. Obernetter, München, reprod.

cher in Jena. 


Zoolog. Jahrbücher Suppl. 14.

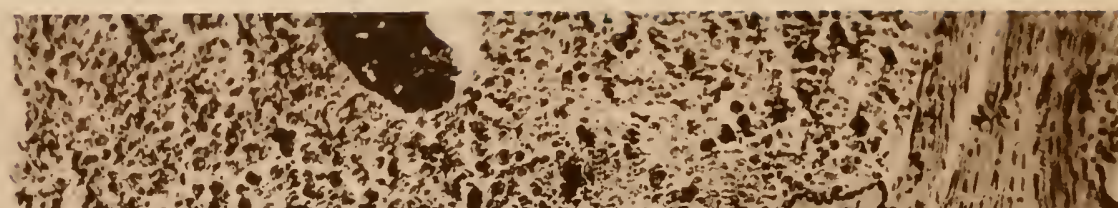

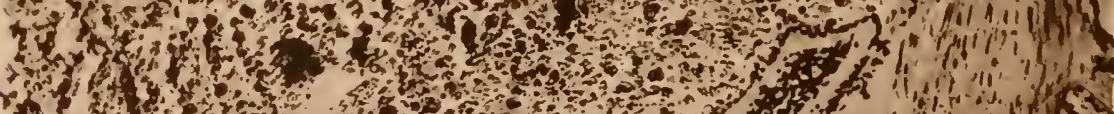

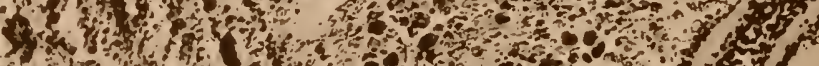

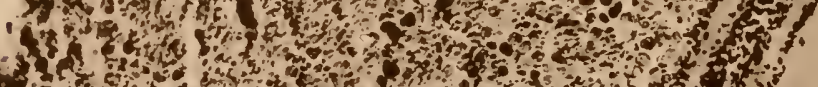

M. 3 (4)

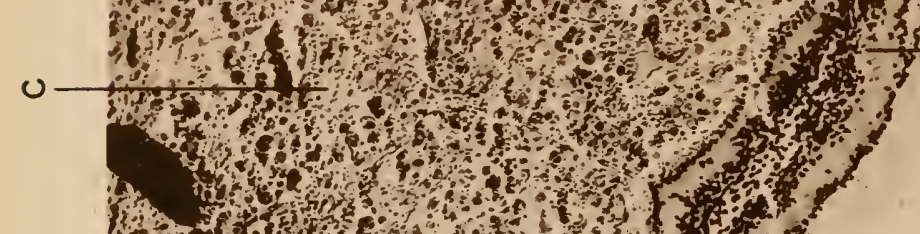

lof

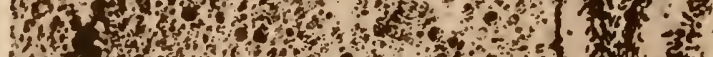

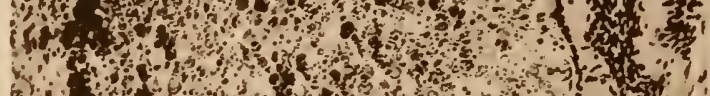

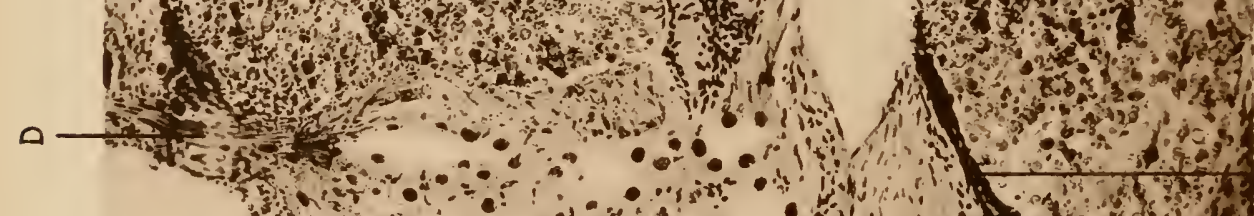

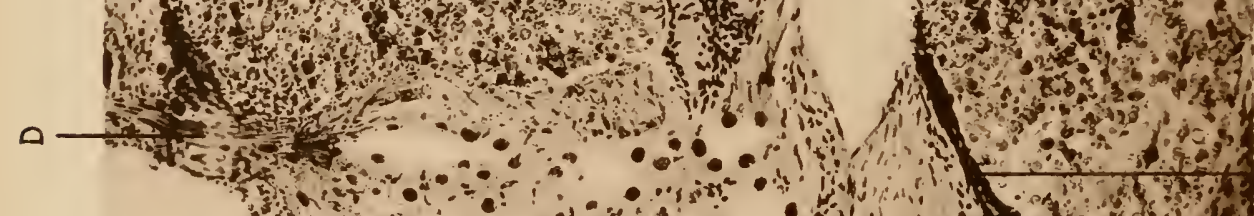

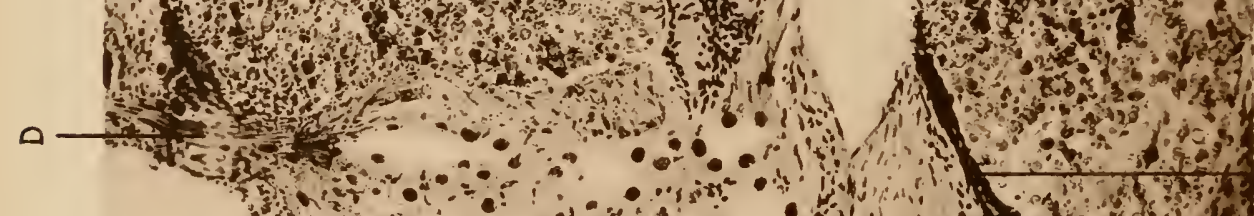
Pin is, a. 40
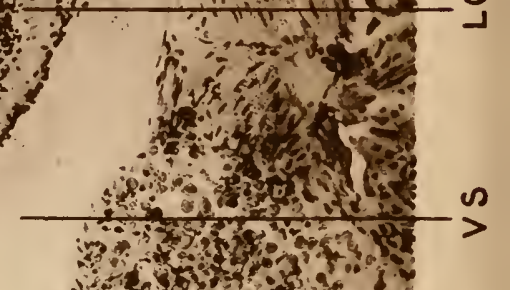
0 ne (3)

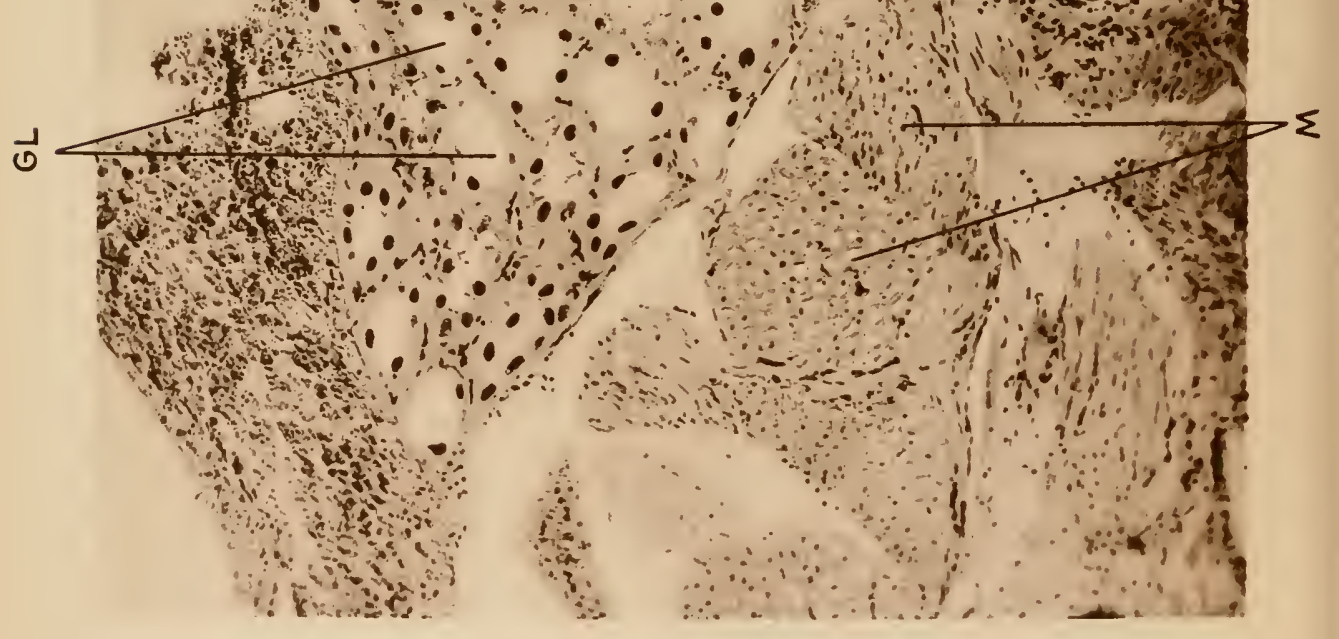

Buxton.

Verlag von Gustav $\boldsymbol{F}$ 
$6 a$

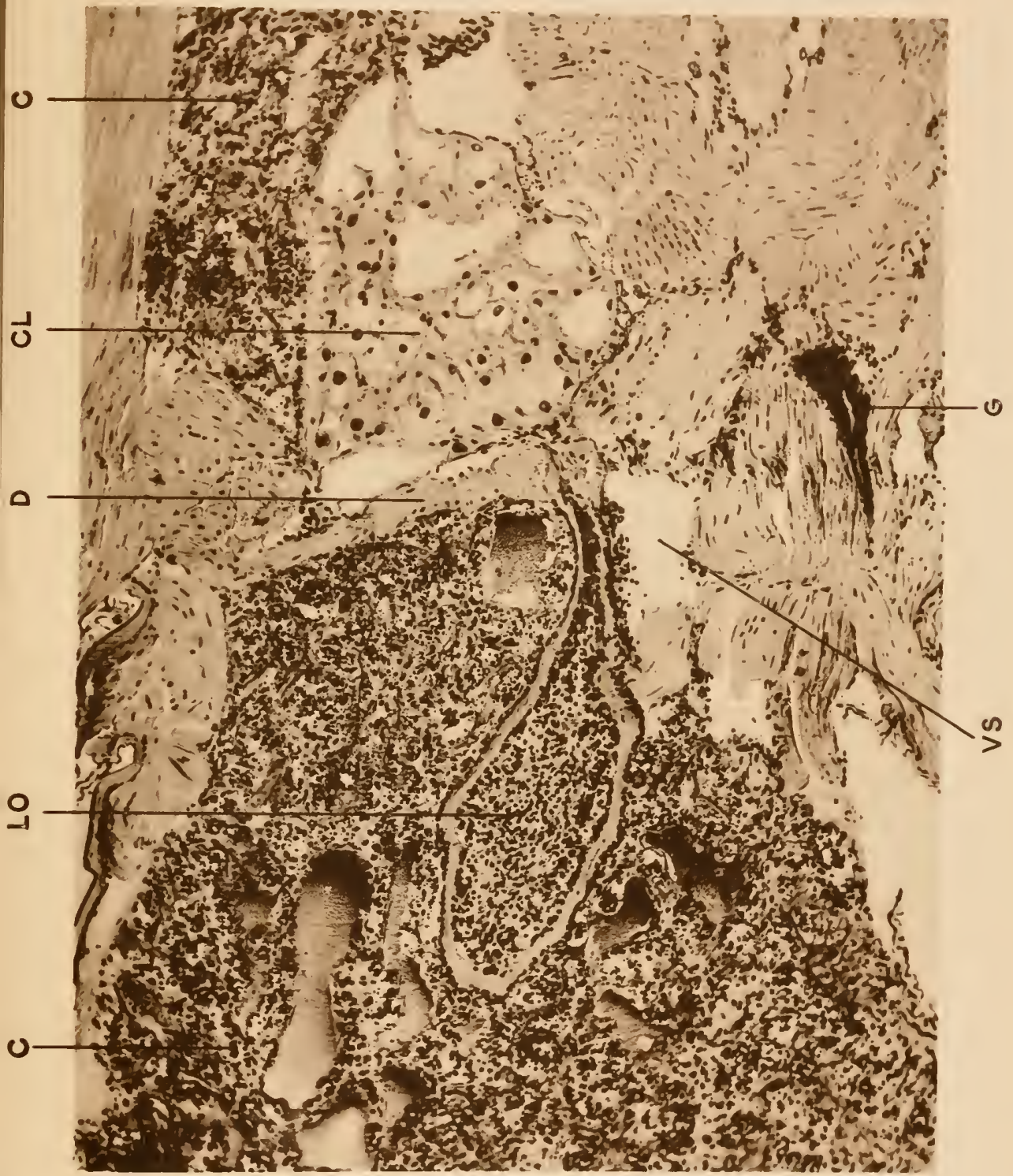

J. B. Obernetter, München, reprod.

"er in Jena. 


Zoolog. Jahrbücher Suppl. 14.

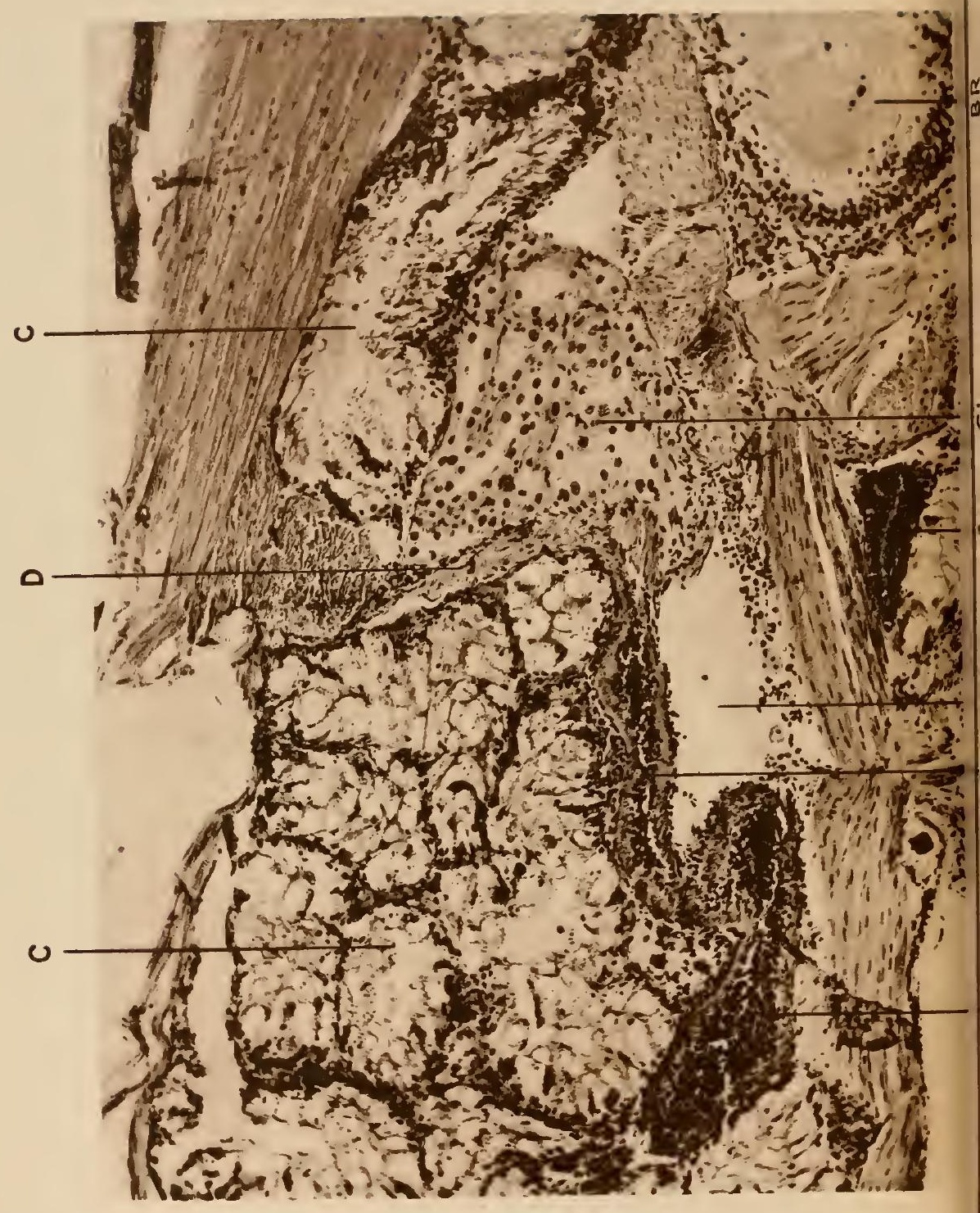

Buxton.

Verlag von Gustav $\mathbf{F}$ 


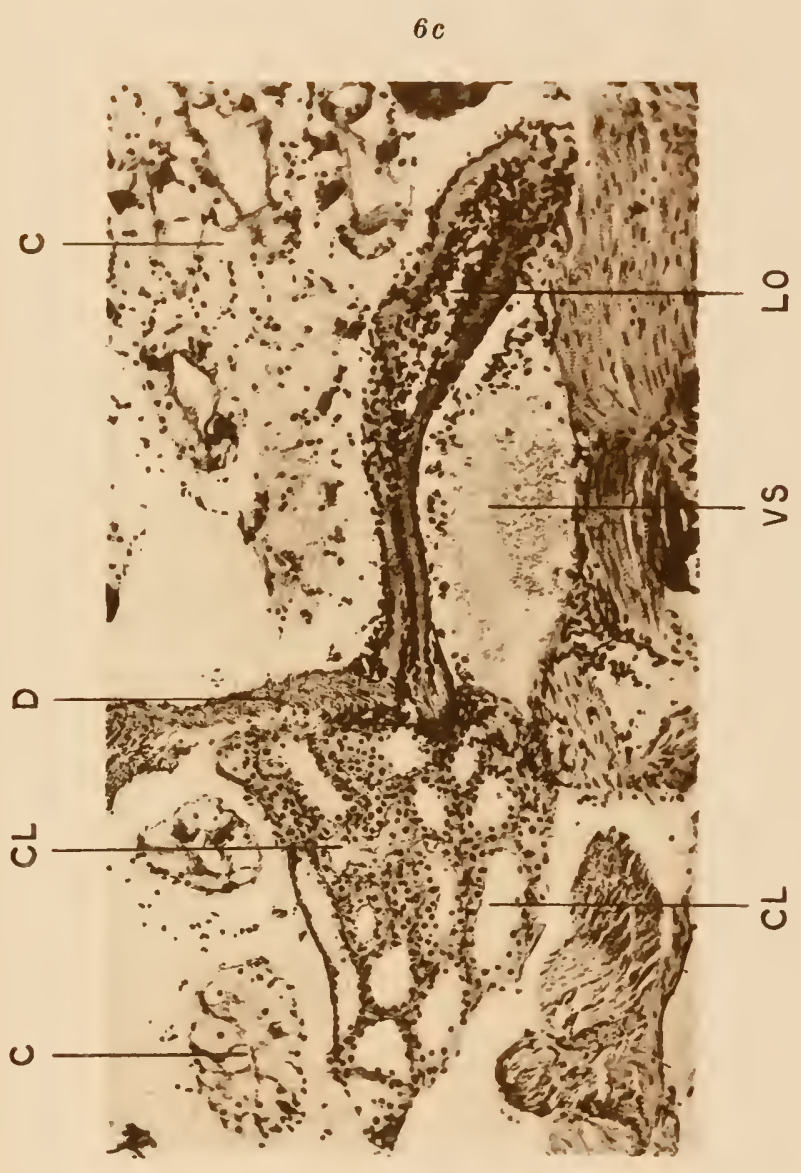

J. B. Obernetter, München, reprod. er in Jena. 


Zoolog. Jahrbücher Suppl. 14

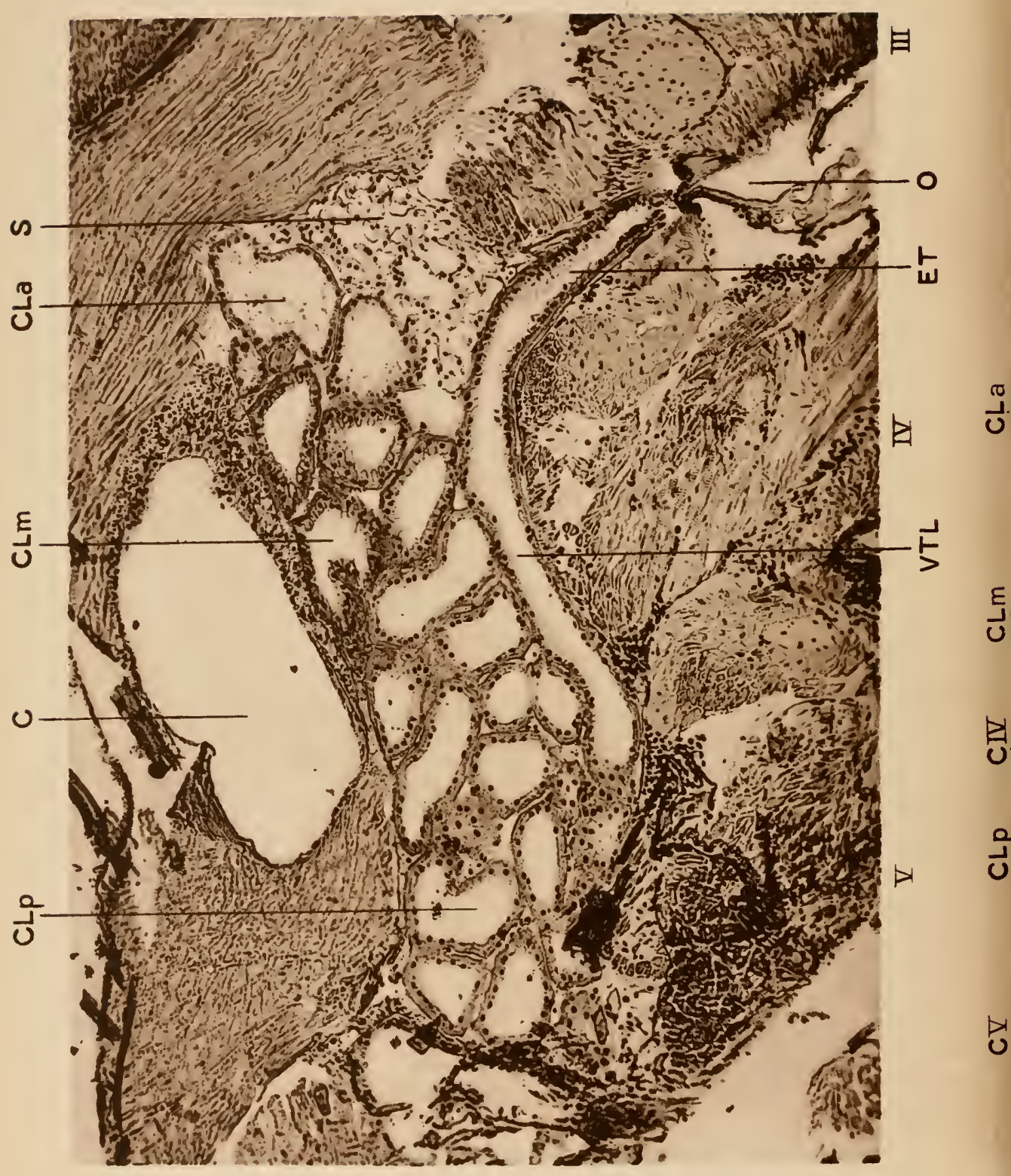

Buxton. 


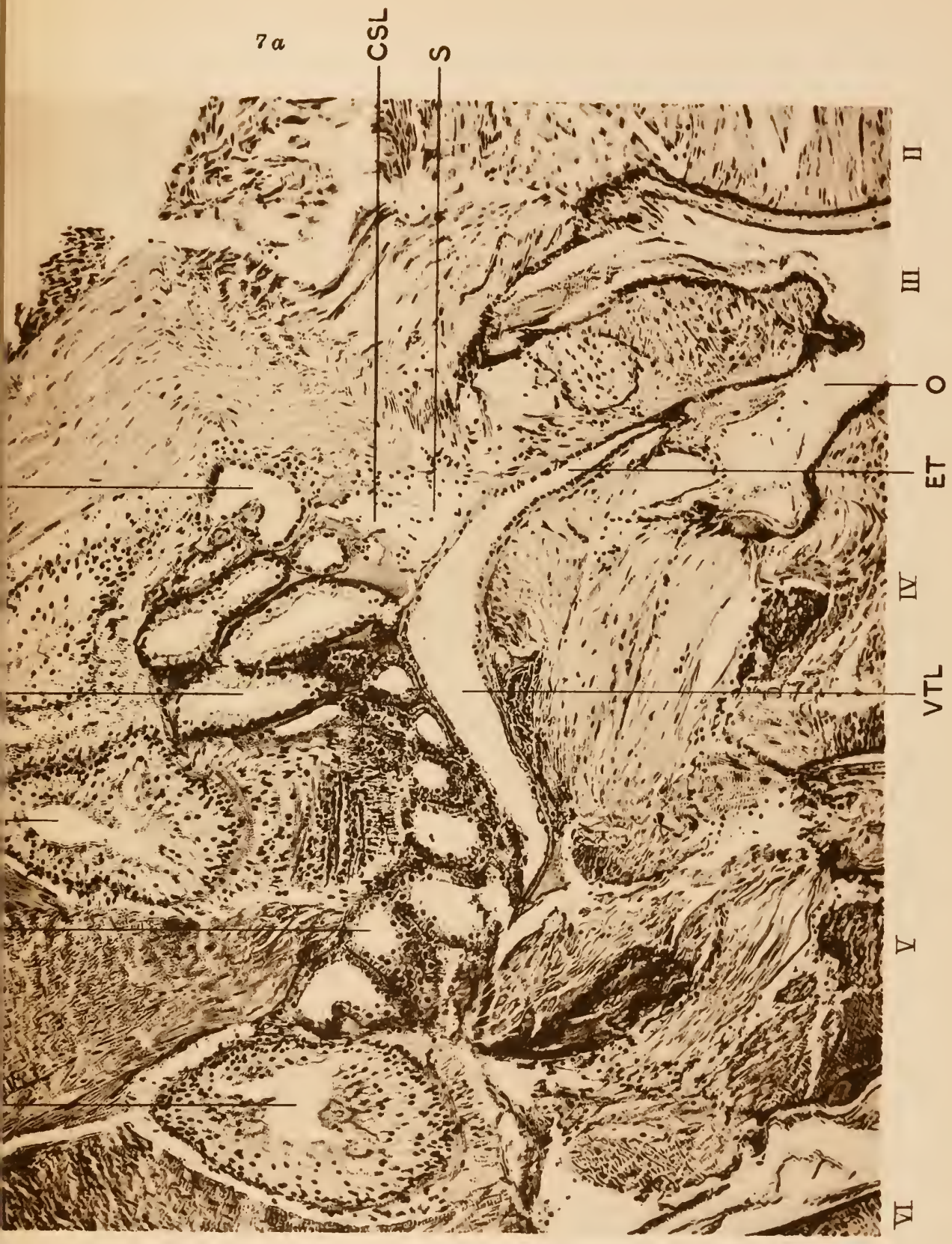

J. B. Obernetter, München, reprod.

in Jena. 

Zoolog. Jahrbücher Suppl. 14.

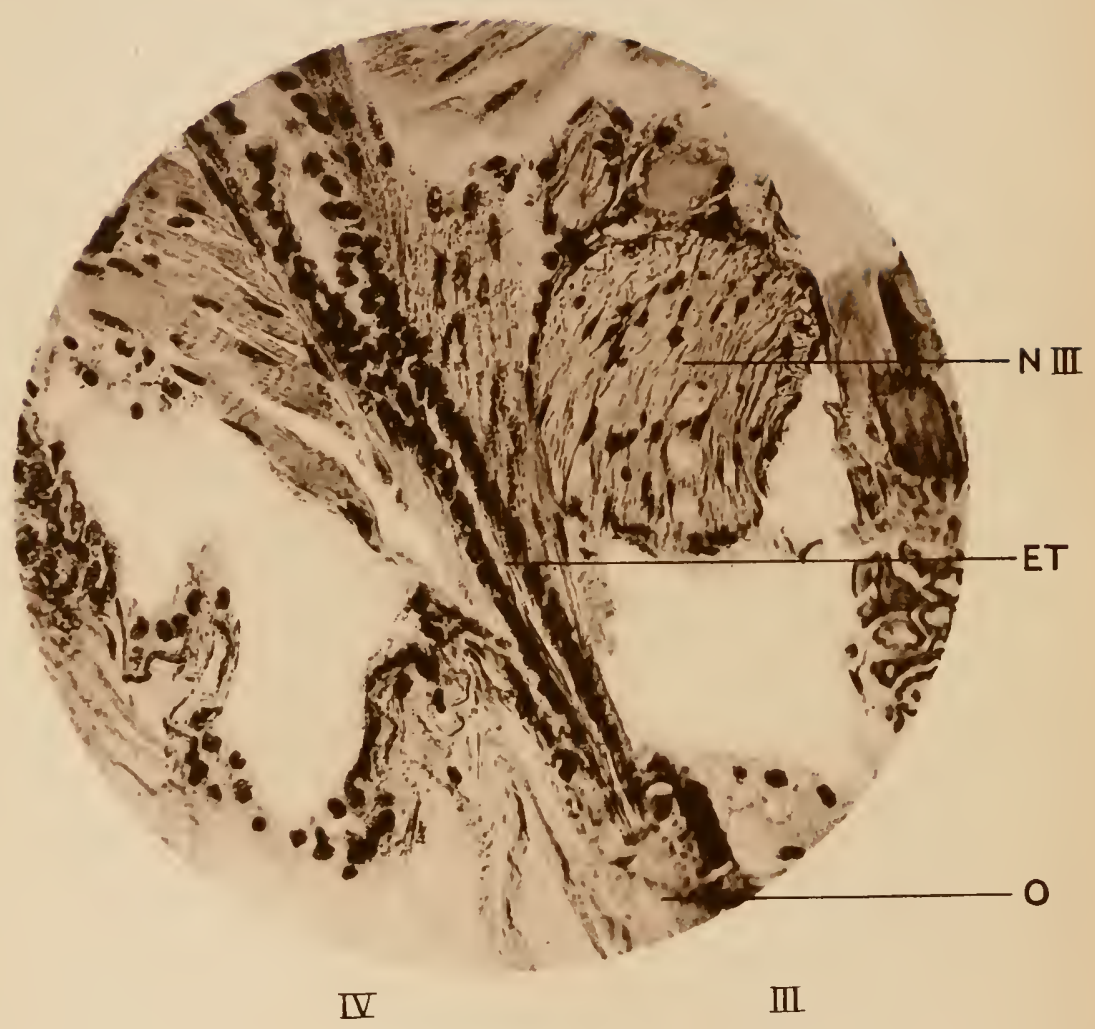

Buxton. 
Taf. 8 .

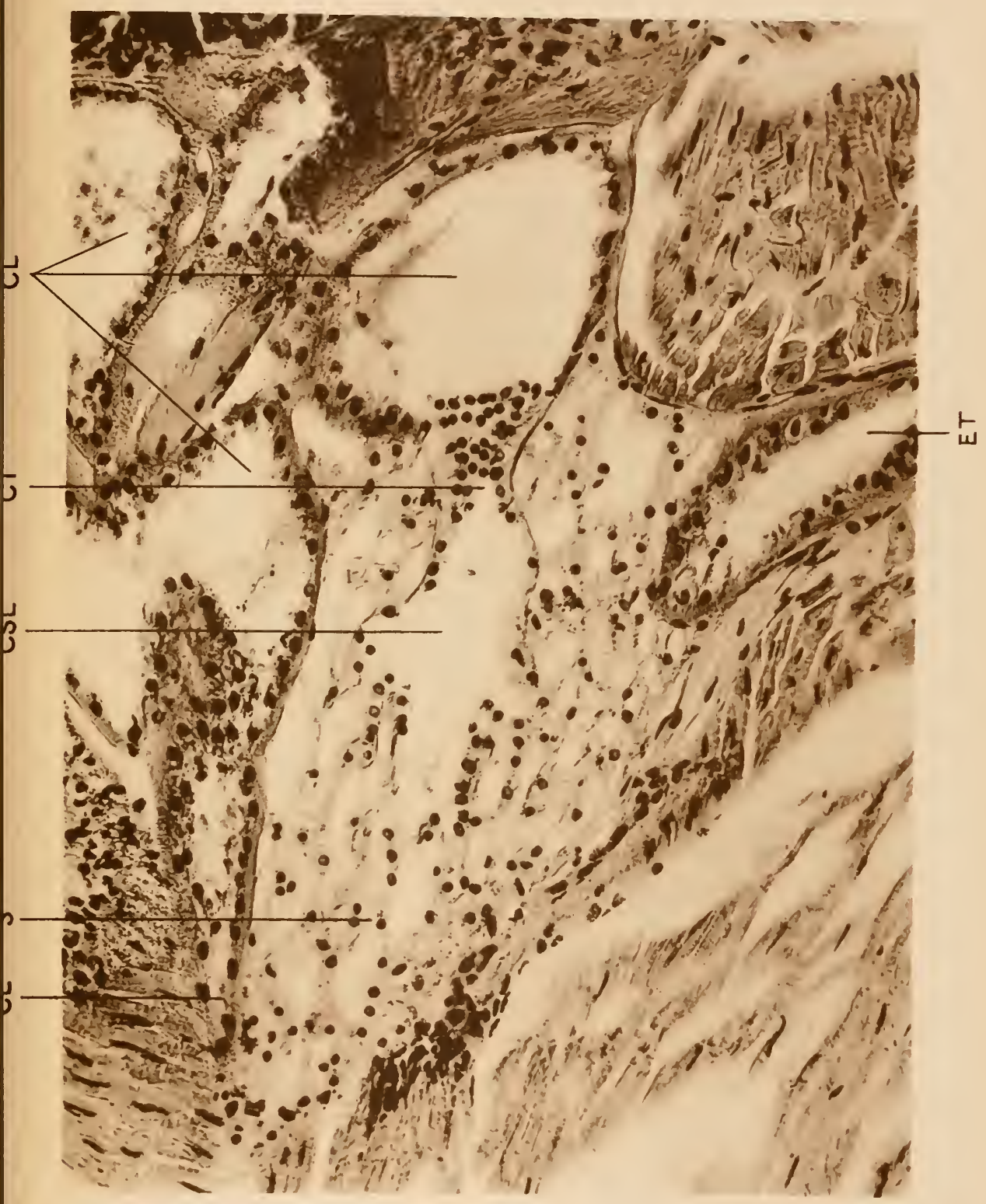

J. B. Obernetter, München, reprod.

cher in Jena. 


Zoolog. Jahrbücher Suppl. 14.
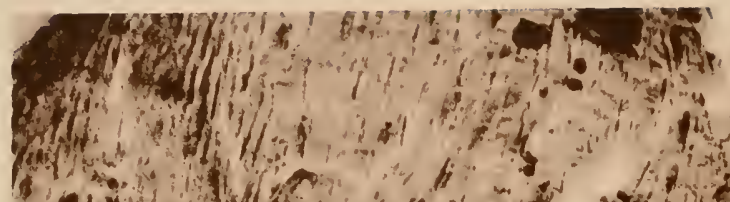

tofin
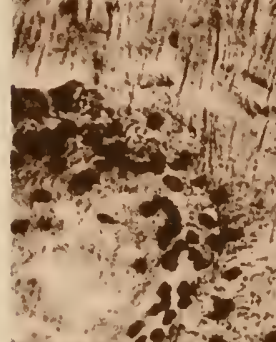

$A-2-3$
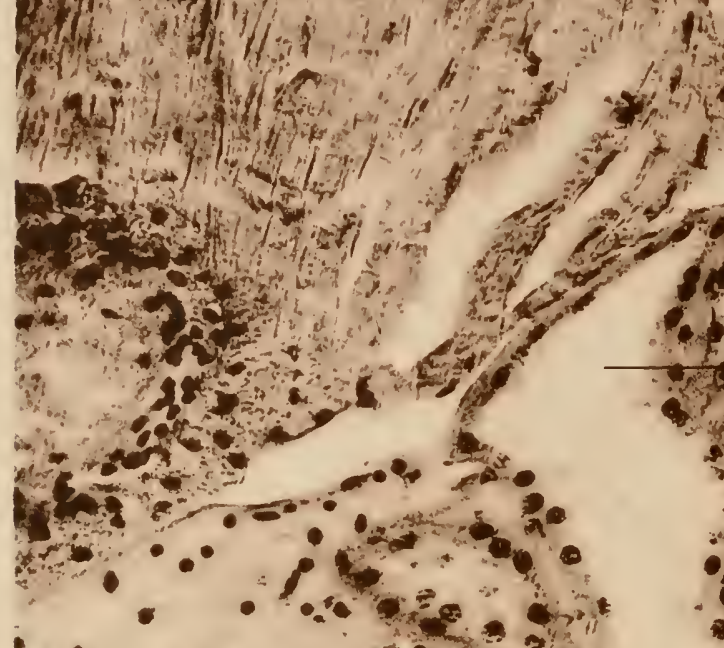

SL

SSL
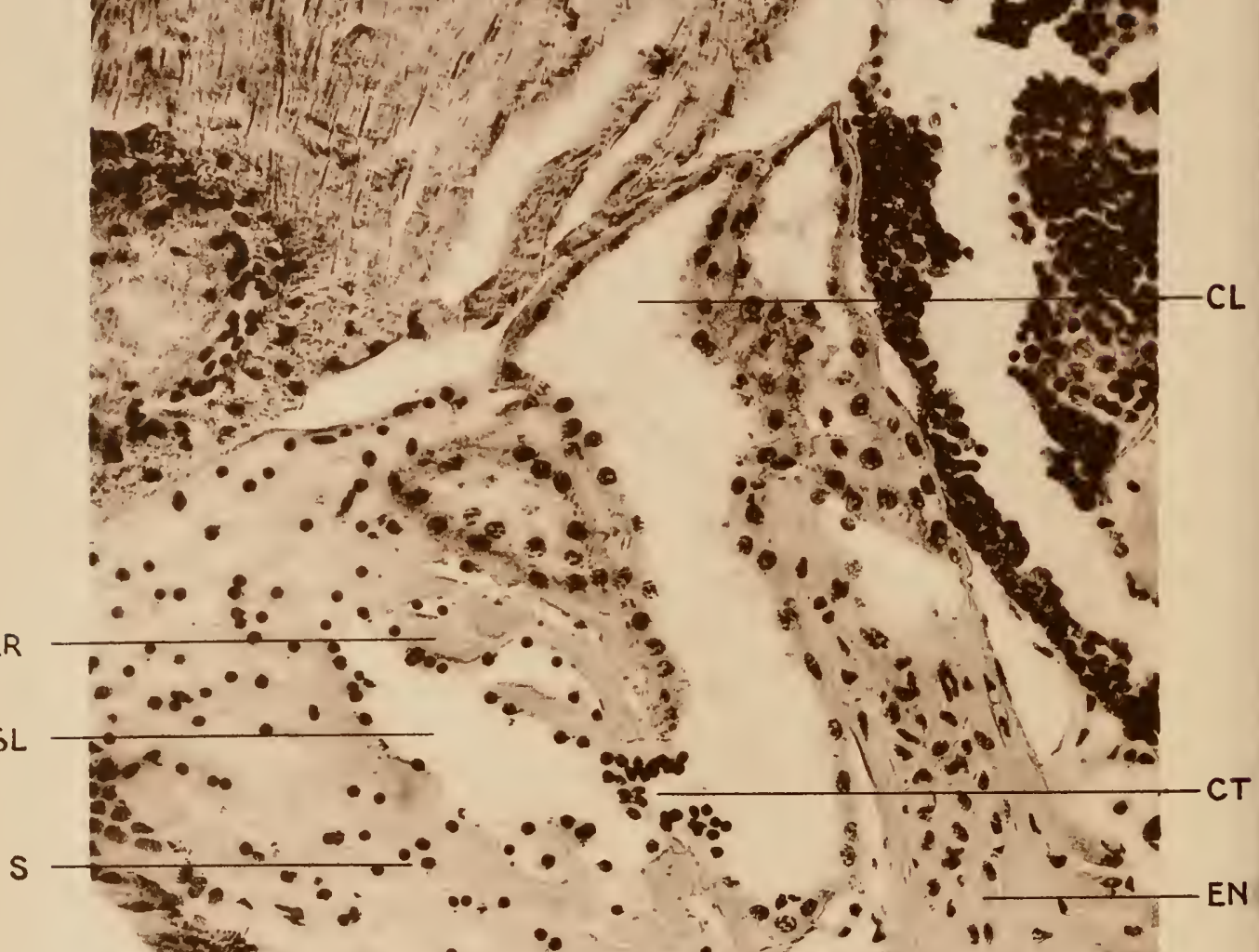

$C L$
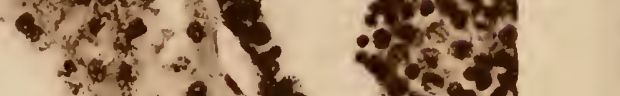

ET

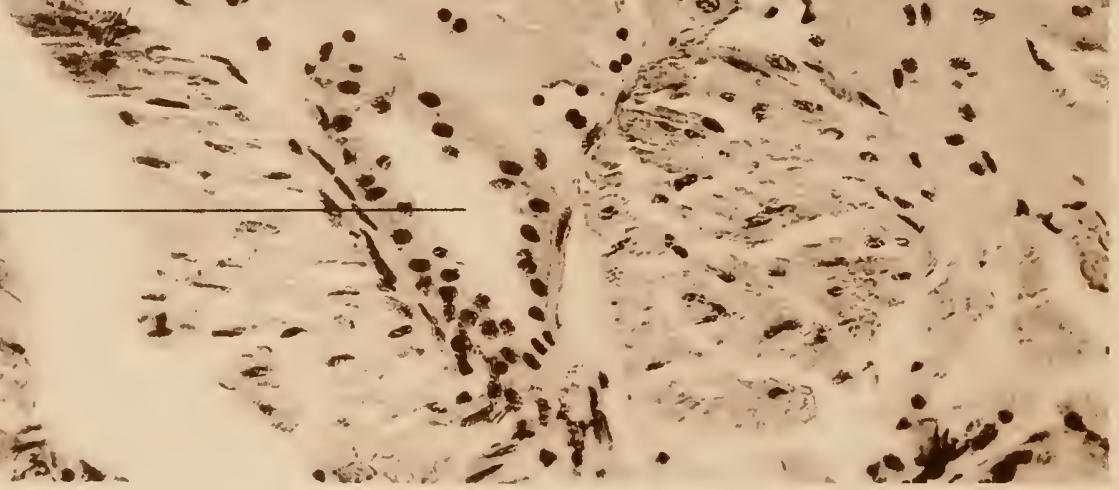

Buxton.

Verlag von Gustav 




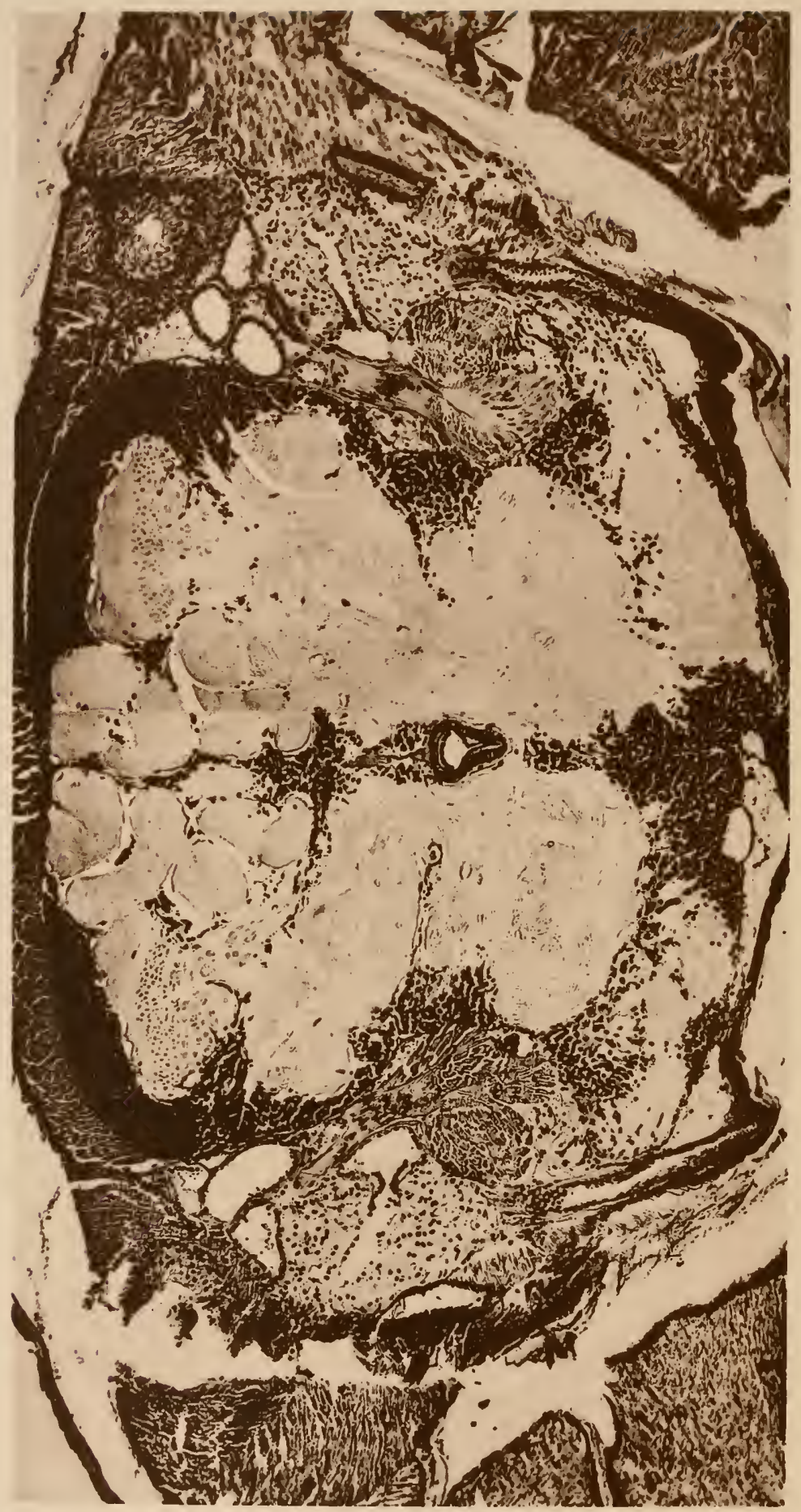

Buxton. 

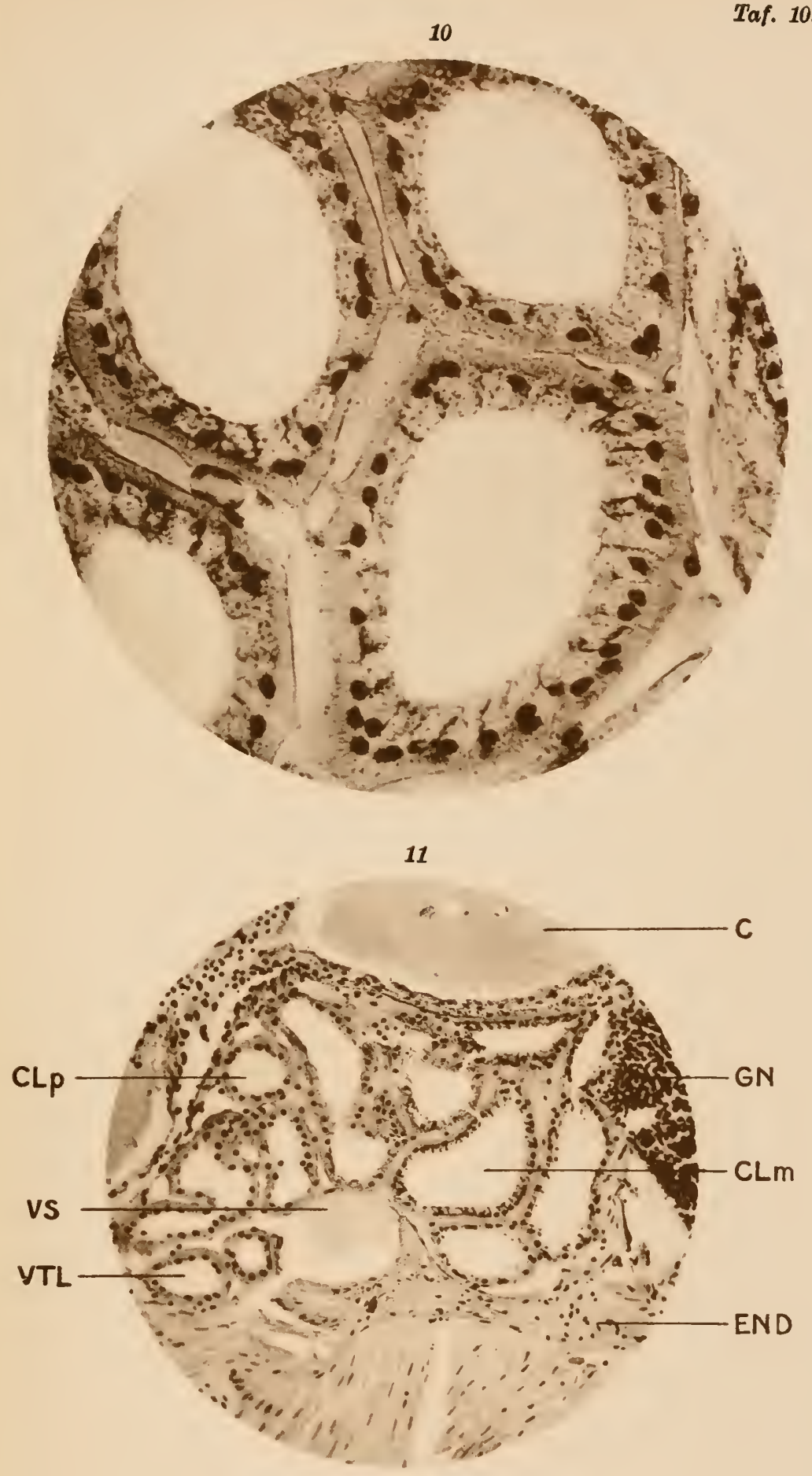

J. B. Obernetter, Mthnchen, reprod. in Jena. 



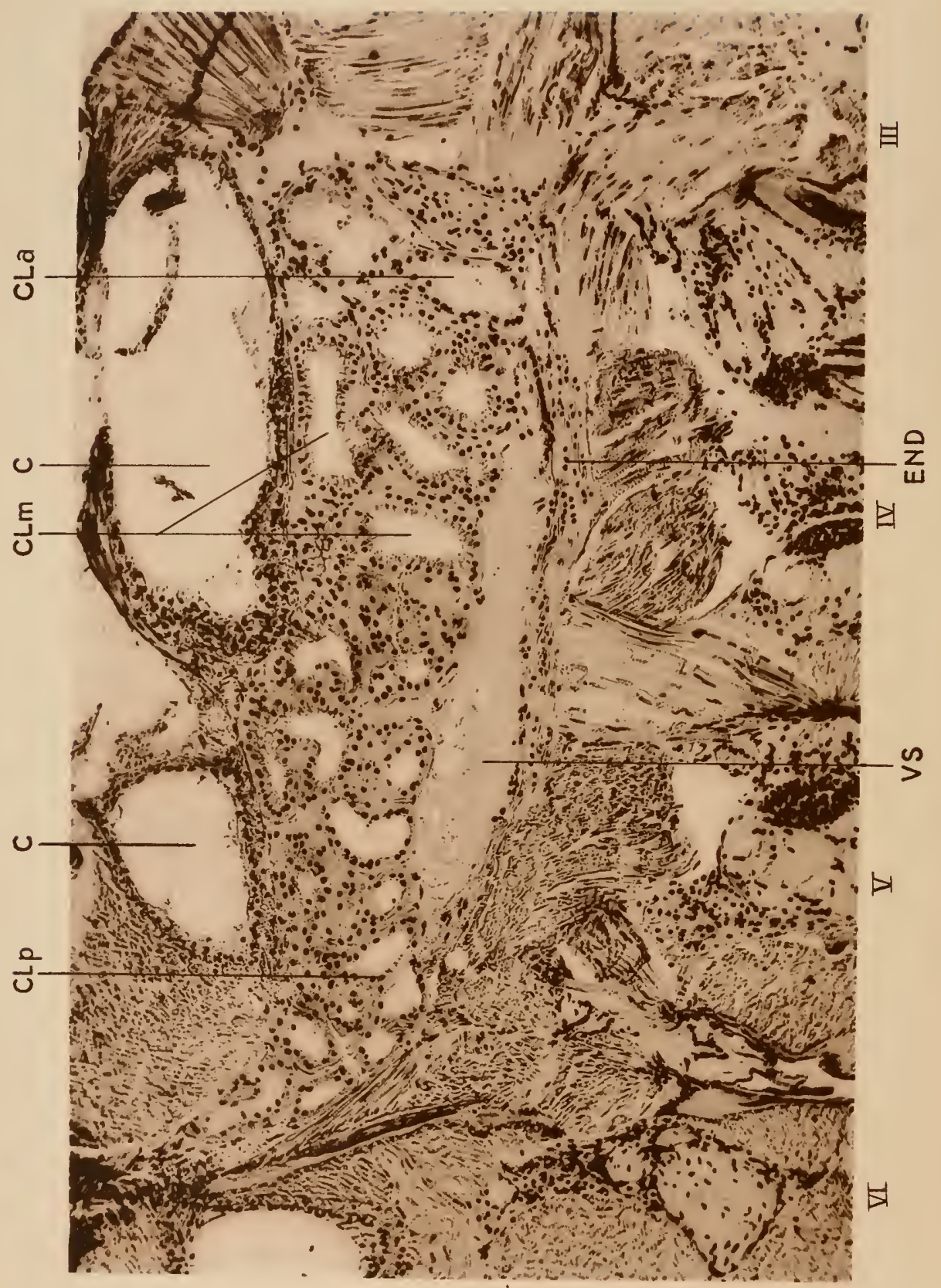

Buxton.

Verlag von Gustav Fi: 
$12 a$

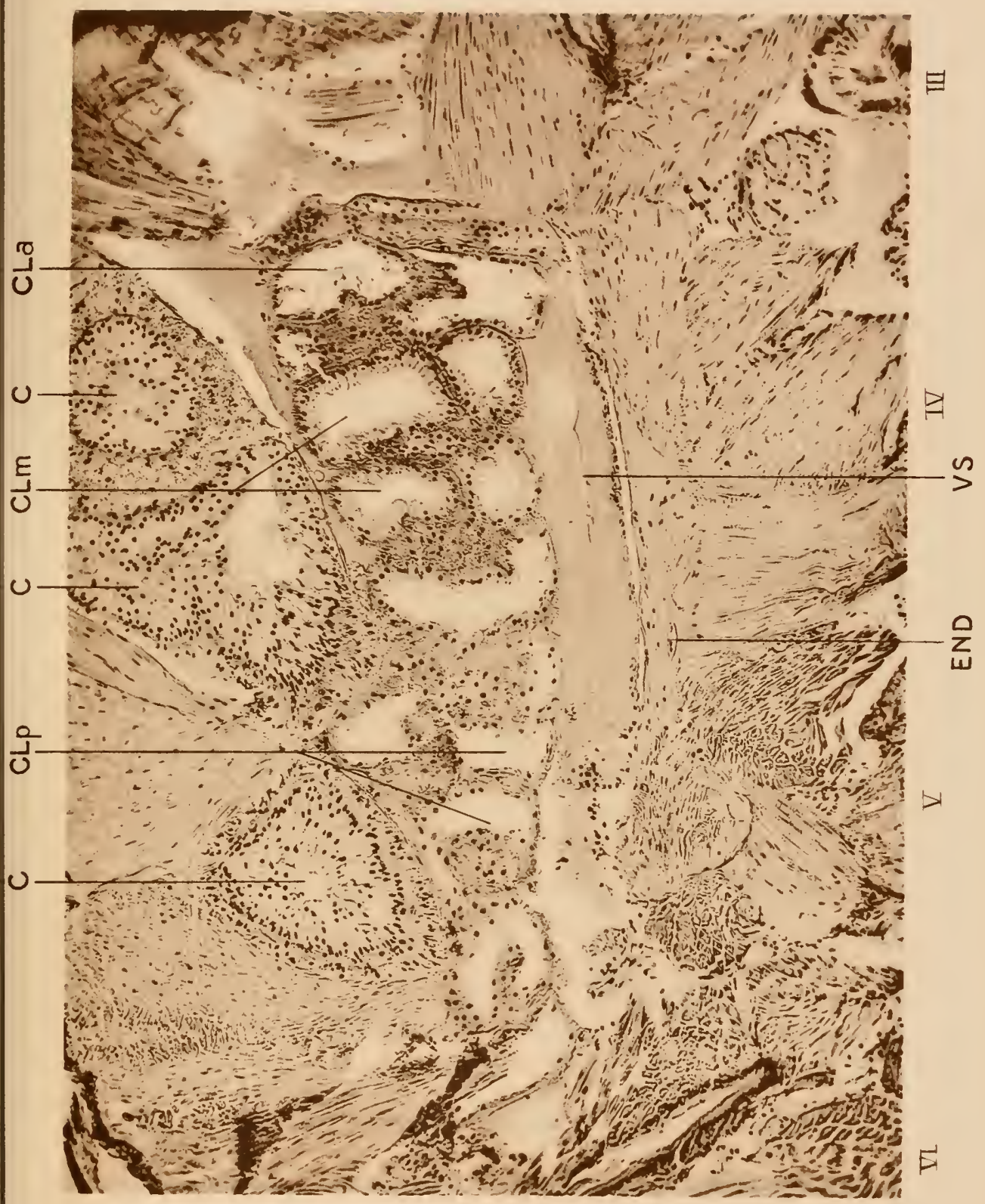

J, B. Obernetter, München, reprod.

$r$ in Jena. 


Zoolog. Jahrbücher Suppl. 14.

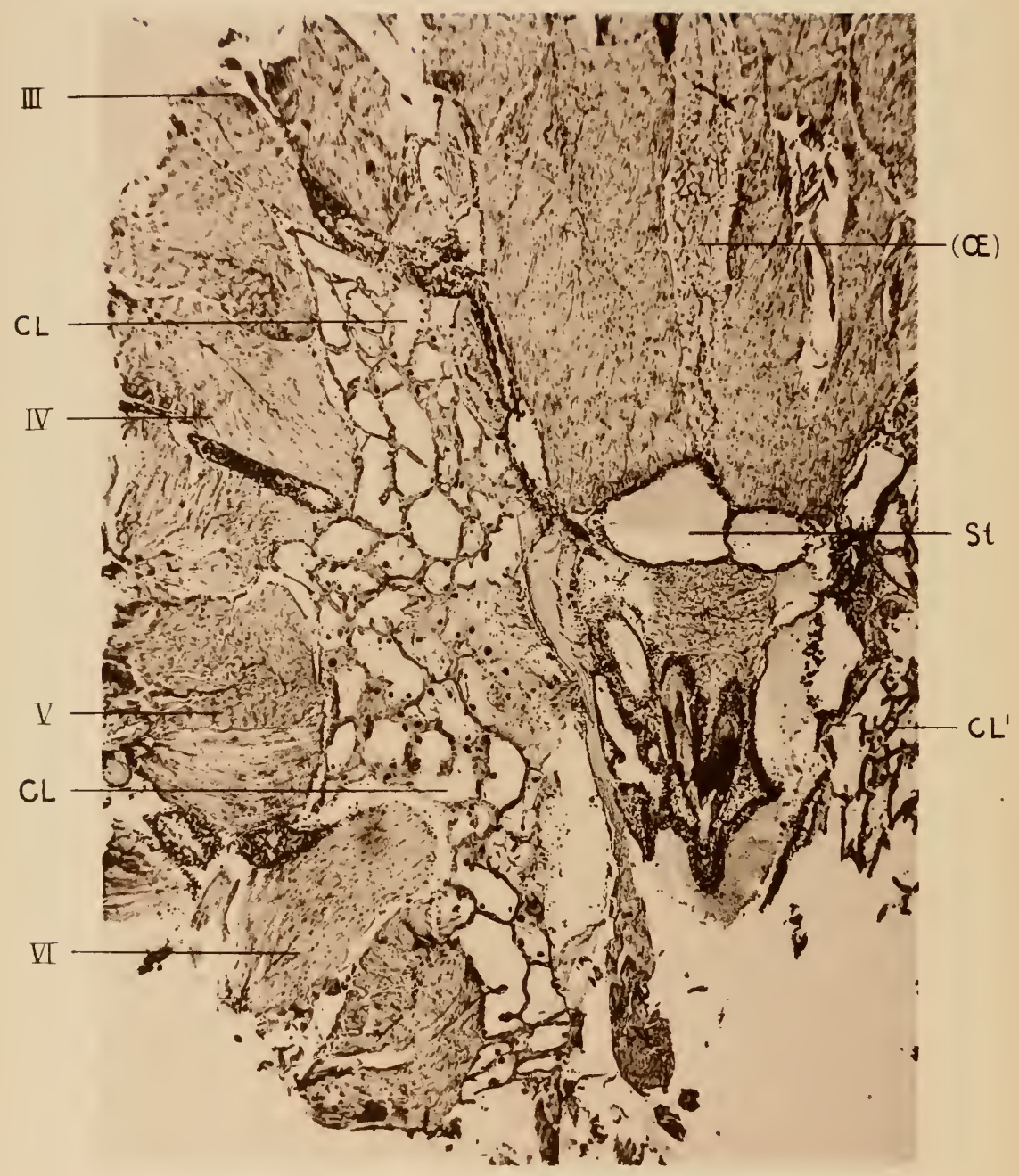

Buxton. 
Taf. 12.

$13 a$

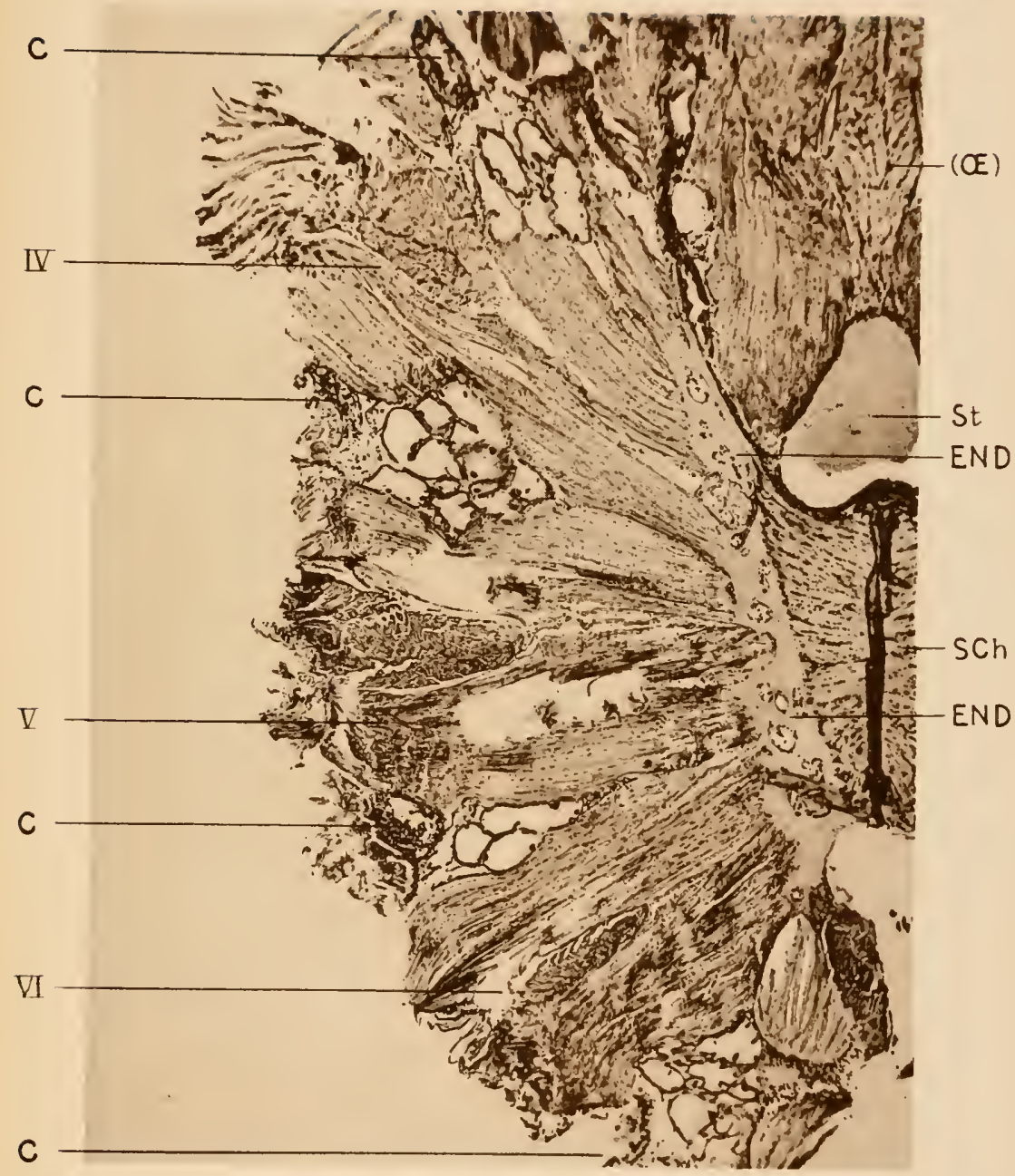

J. B, Obernetter, München, reprod.

er in Jena. 


Zoolog. Jahrbücher Suppl. 14.
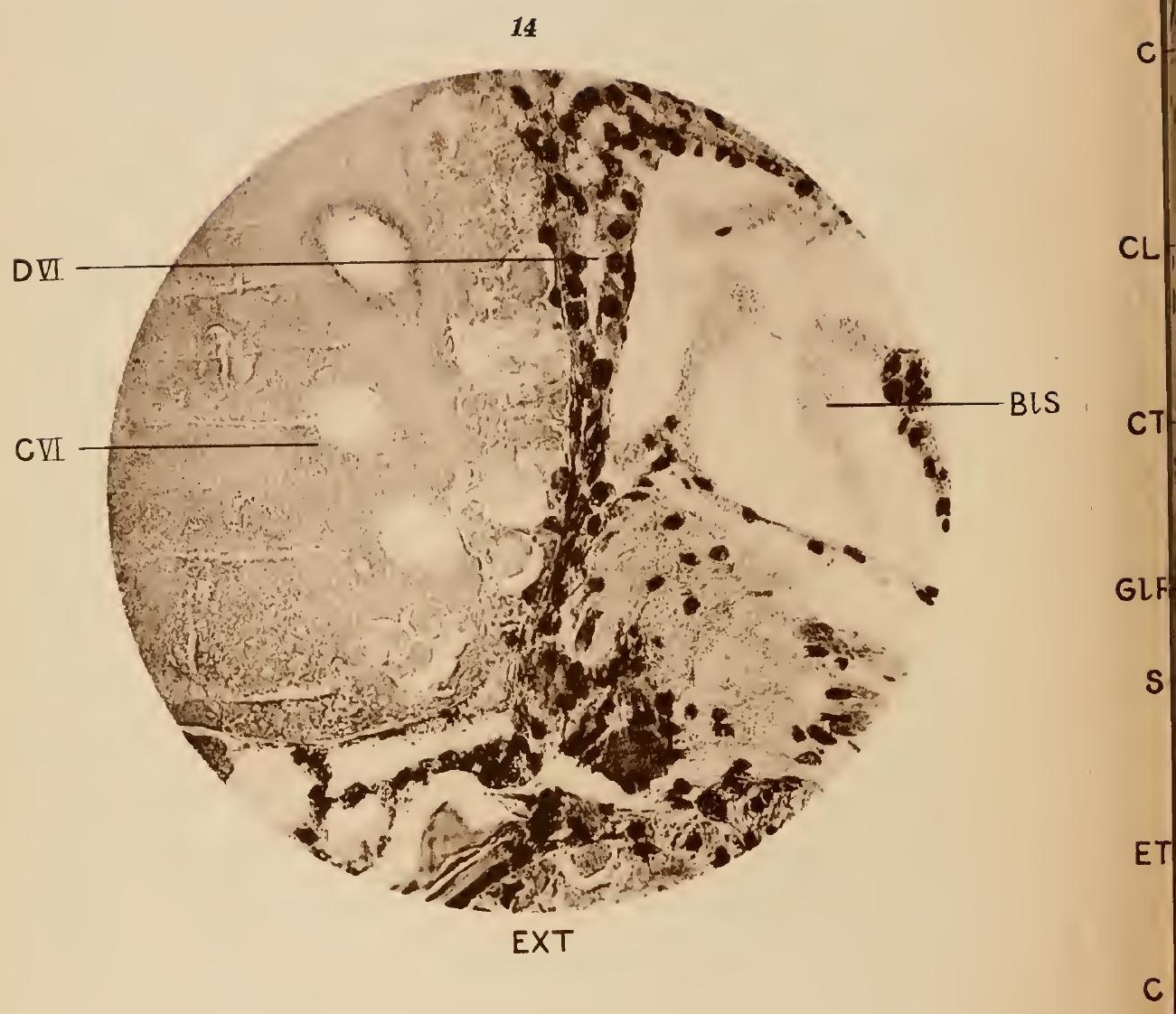

Buxton. 



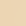


$15 a$

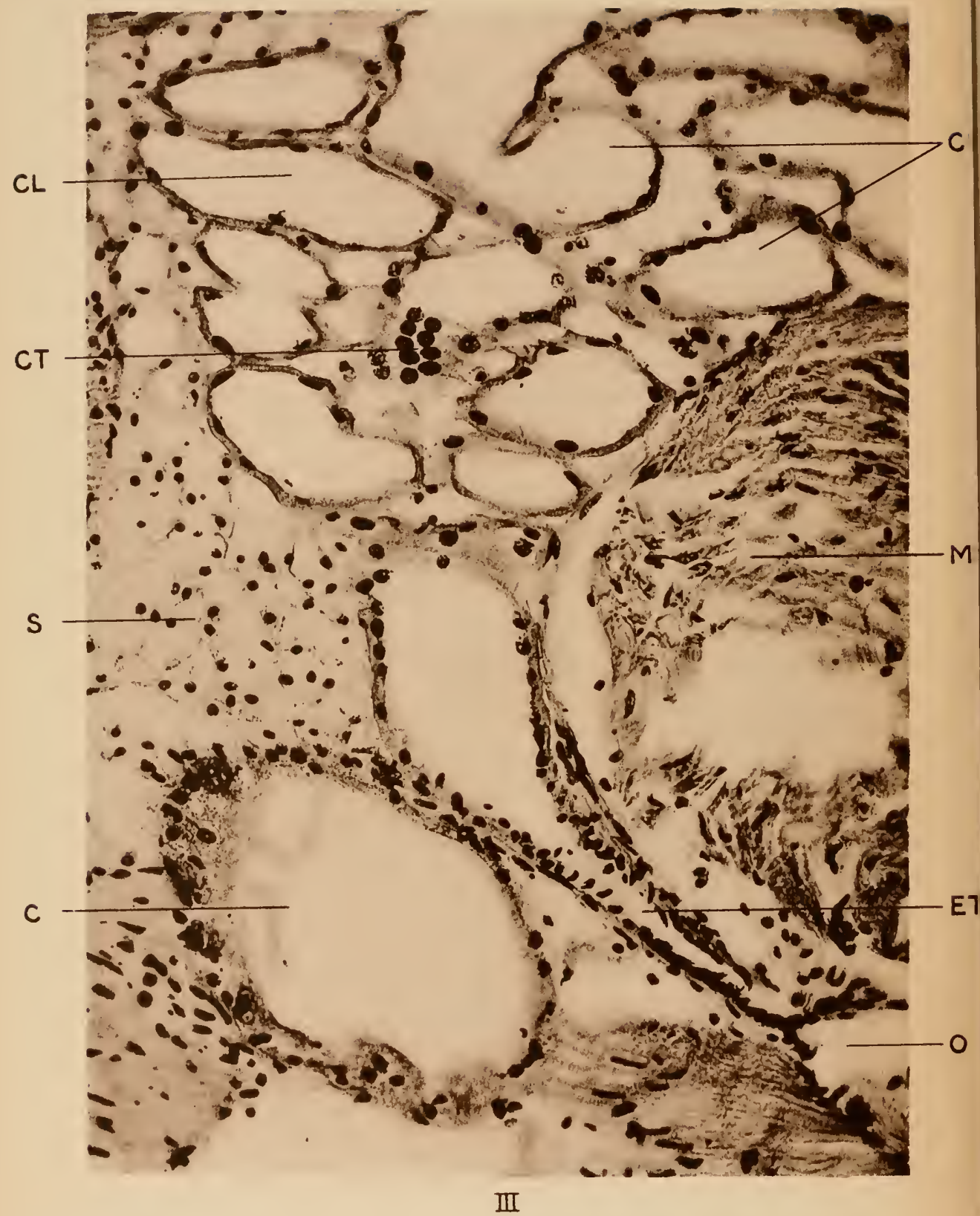


Taf. 14.

$15 b$

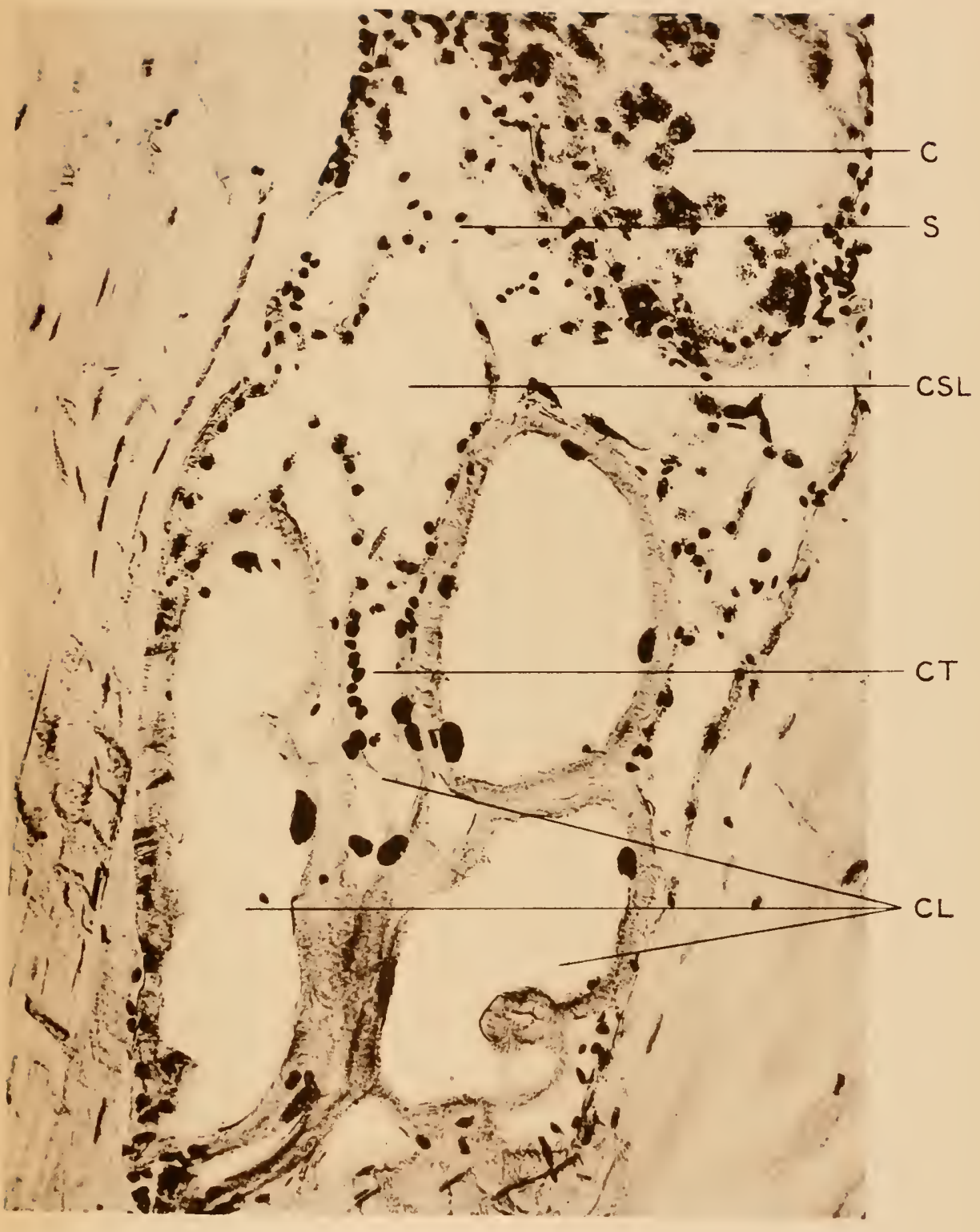

J. B. Obernetter, München, ireprod.

in Jena. 




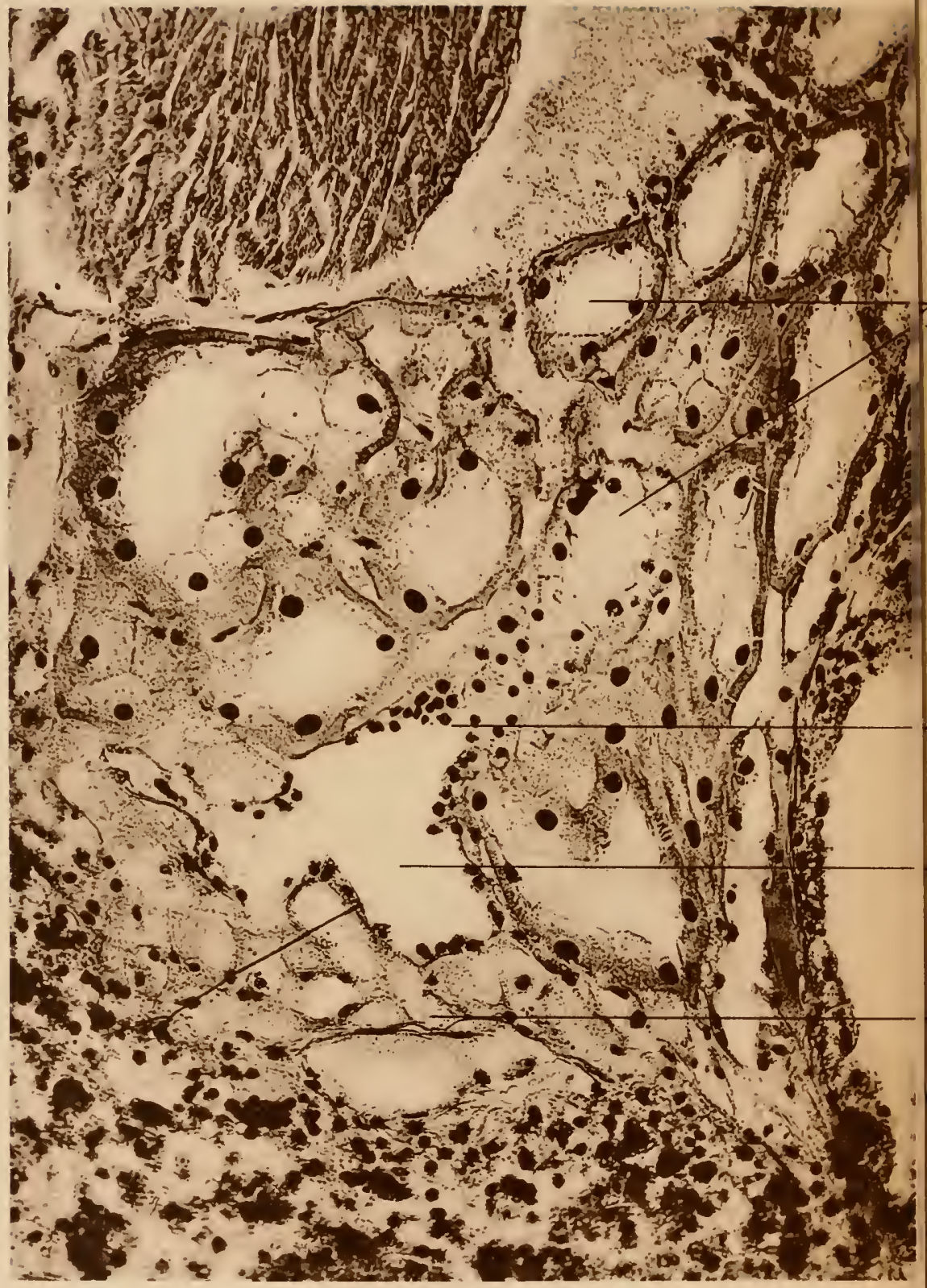


Taf. 15.

$16 a$

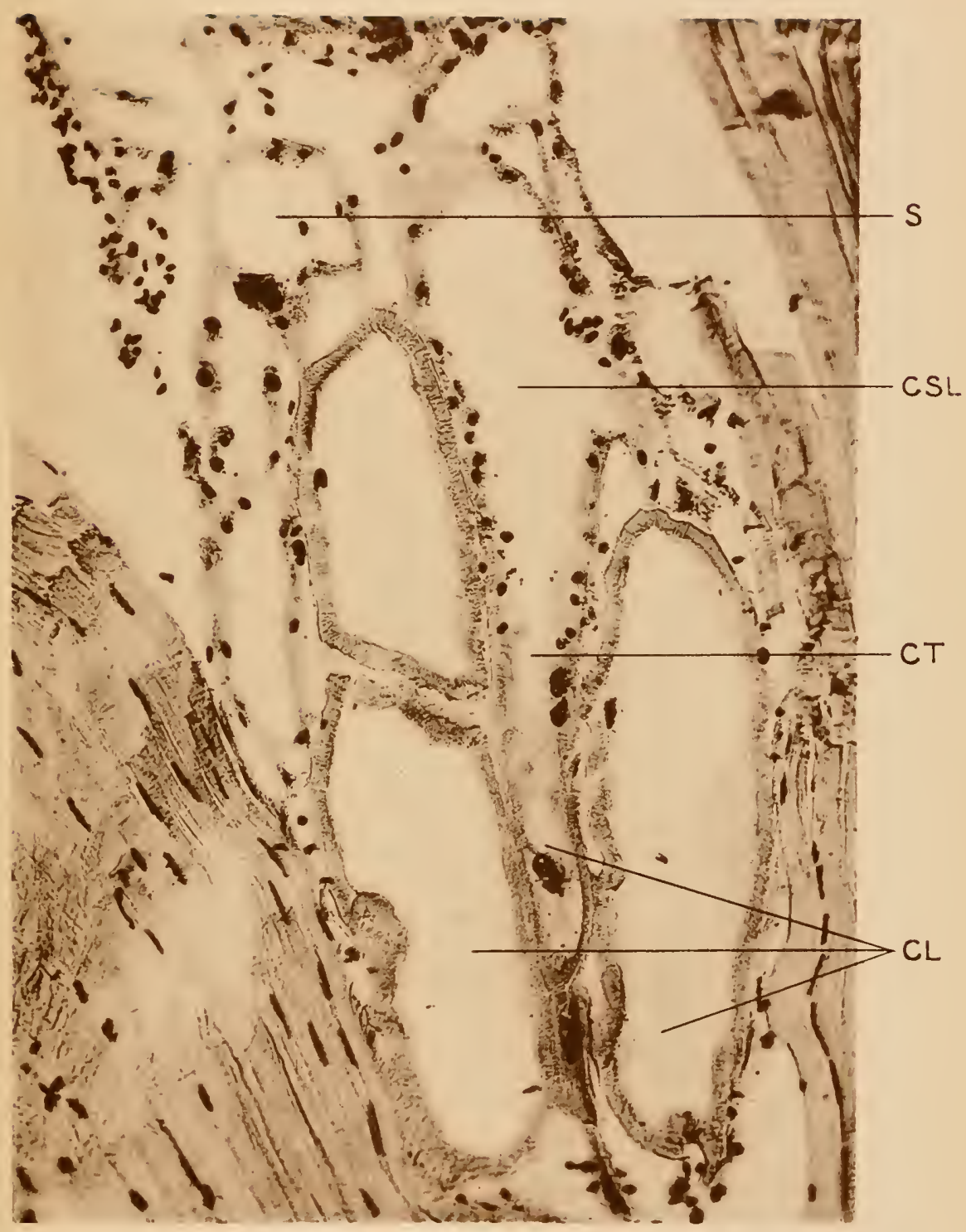

J. B. Obernetter, München, reprod.

Fischer in Jena. 


Zoolog. Jahrbücher Suppl. 14.

$16 b$

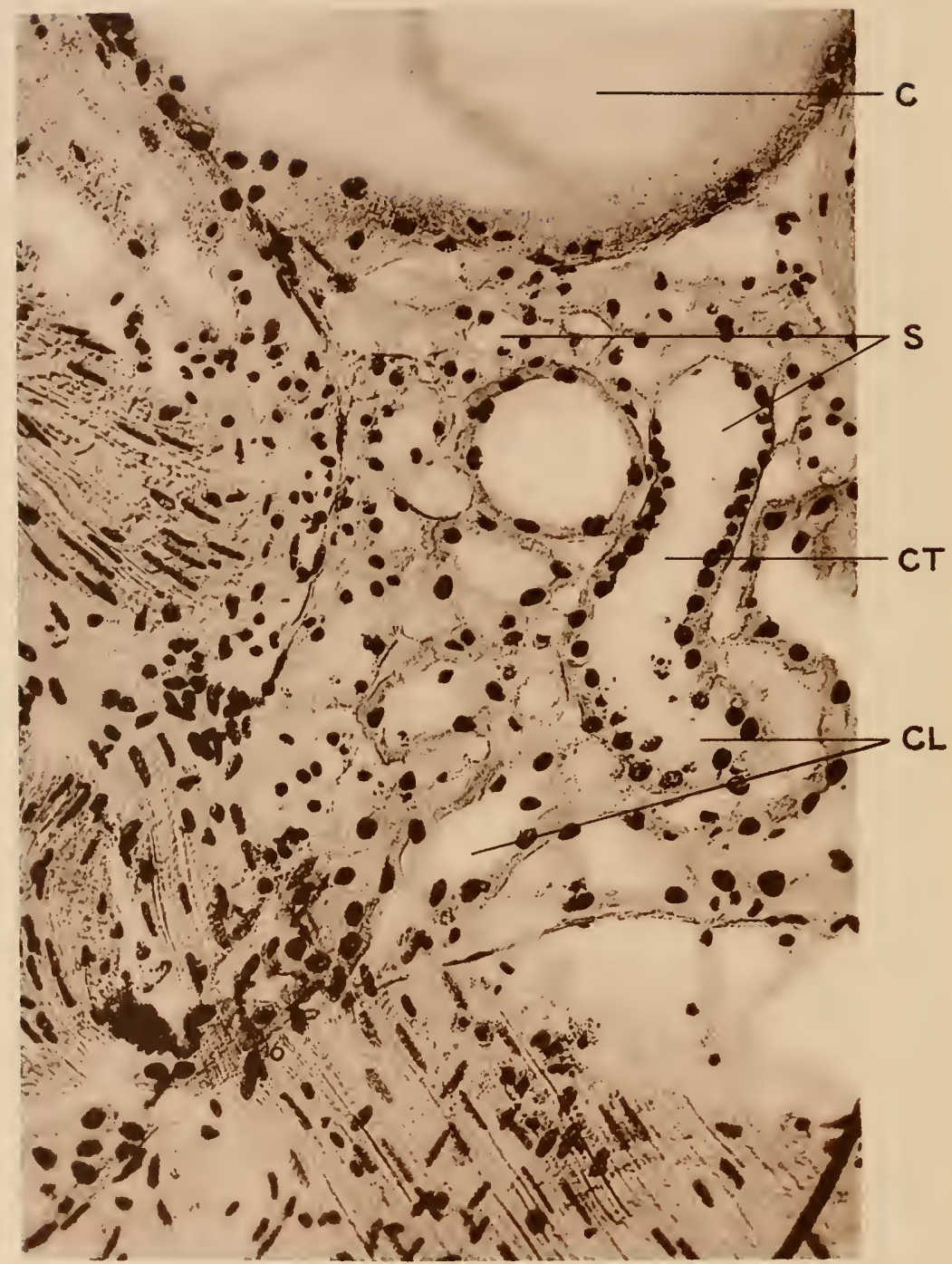




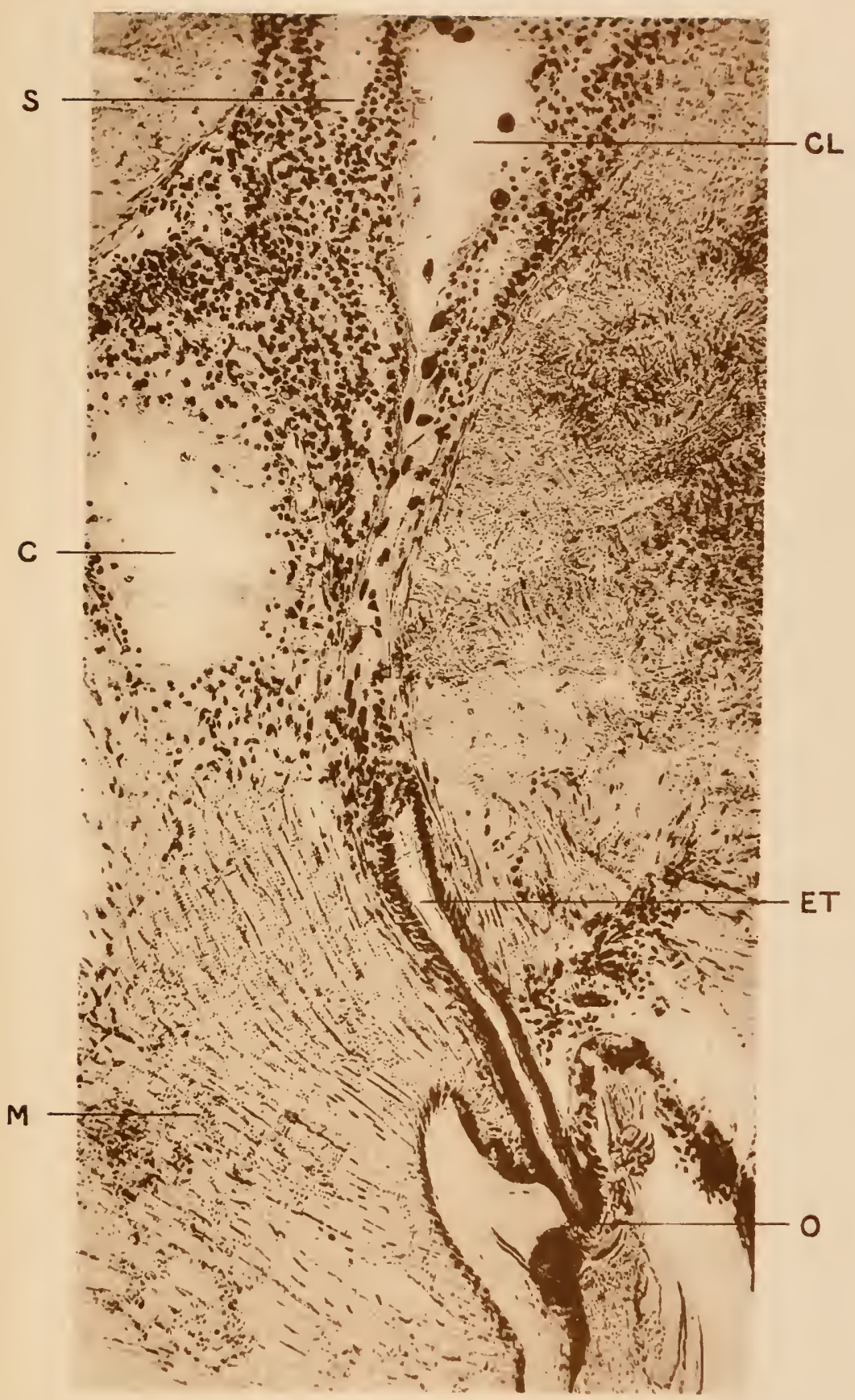

J. B. Obernetter, München, reprod. 


Zoolog. Jahrbücher Suppl. 14.

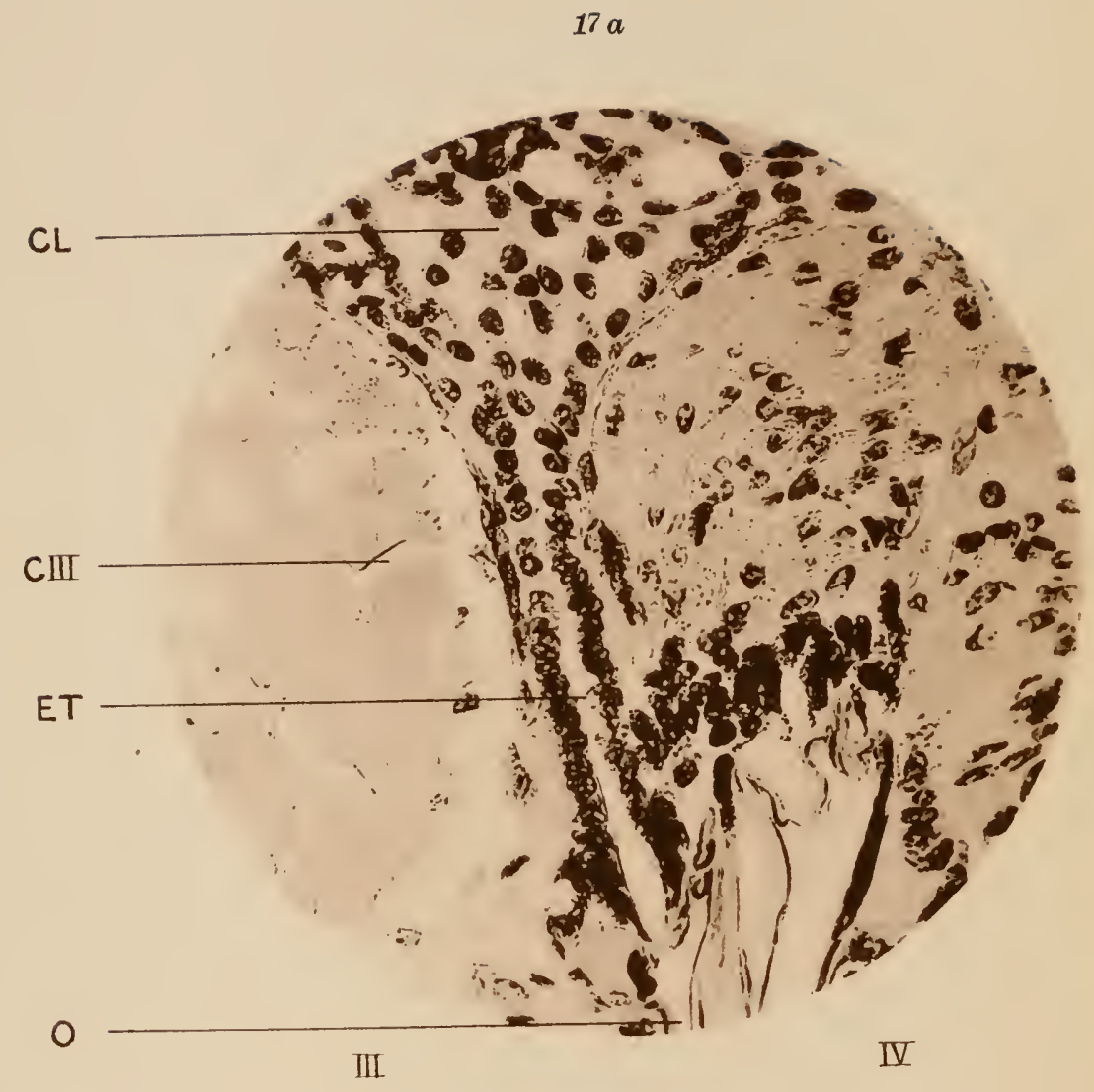

Buxton.

Verlag von Gustan 


\section{Taf, 17.}

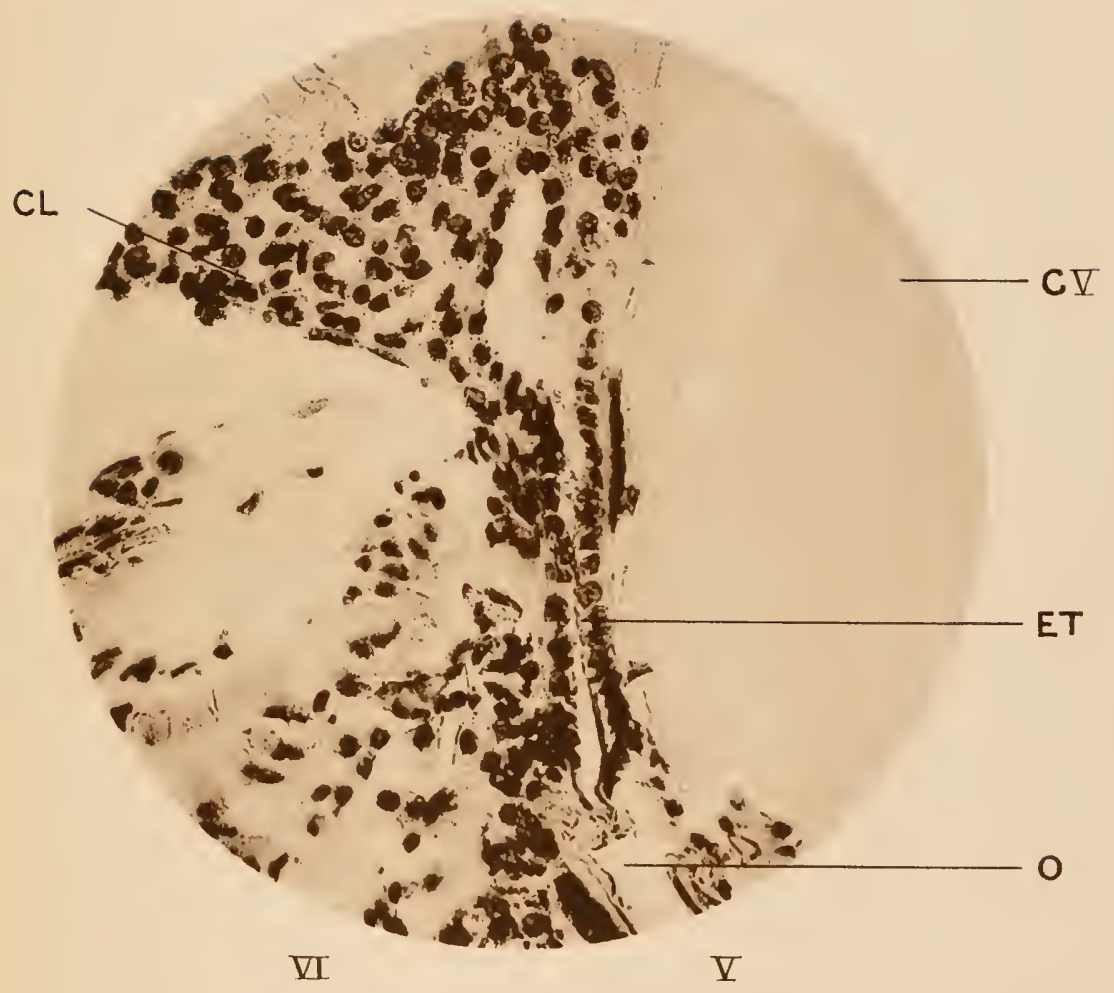

J, B. Obernetter, München, reprod.

scher in Jena. 


Zoolog. Jahrbücher Suppl. 14.

$18 a$

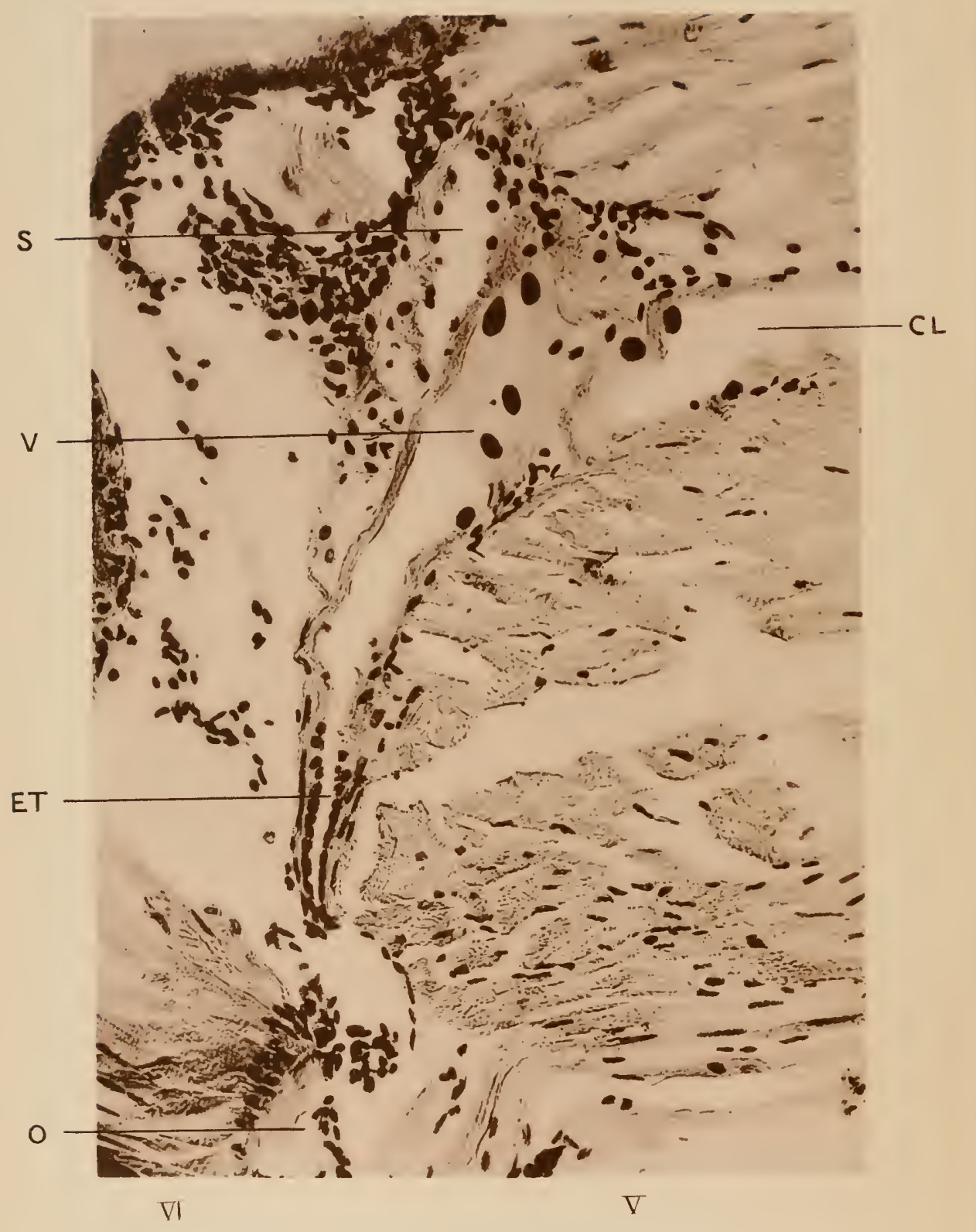

Buxton

Verlag von Gus 
Taf. 18.

$18 b$

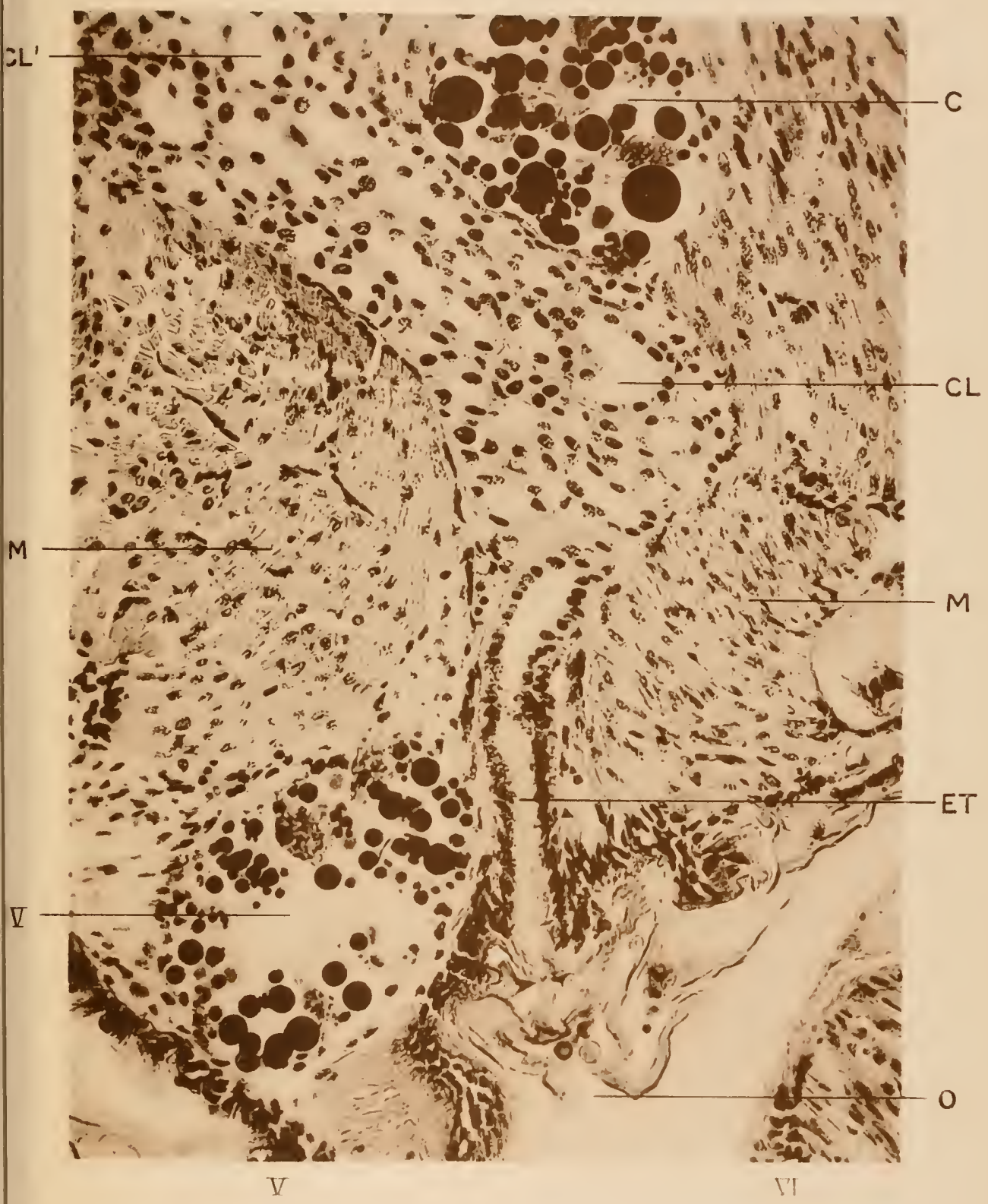

J. B. Obernetter, München, reprod.

Fischer in Jena. 


Zoolog. Jahrbücher Suppl. 14.

$18 c$

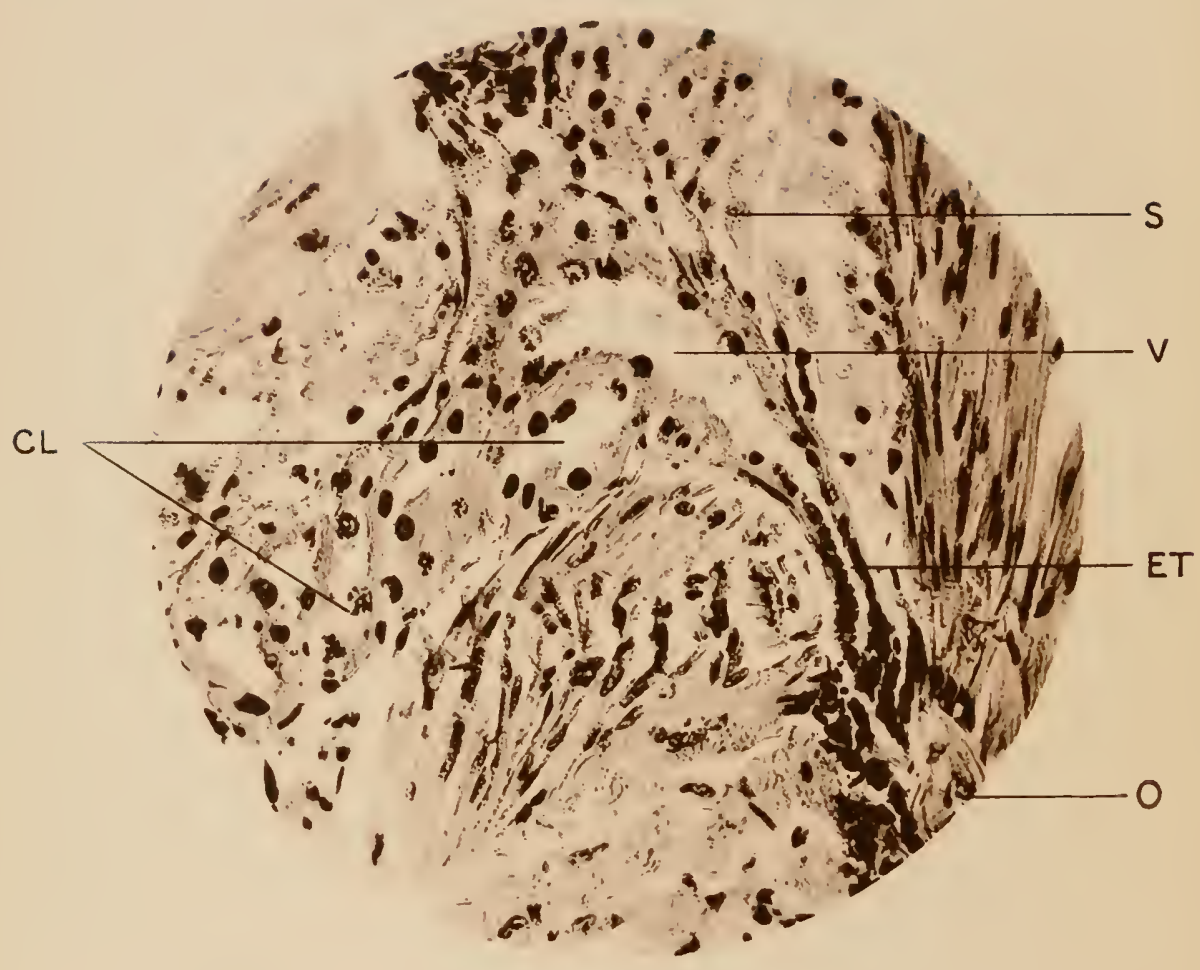

Buxton. 
Taf. 19.

19

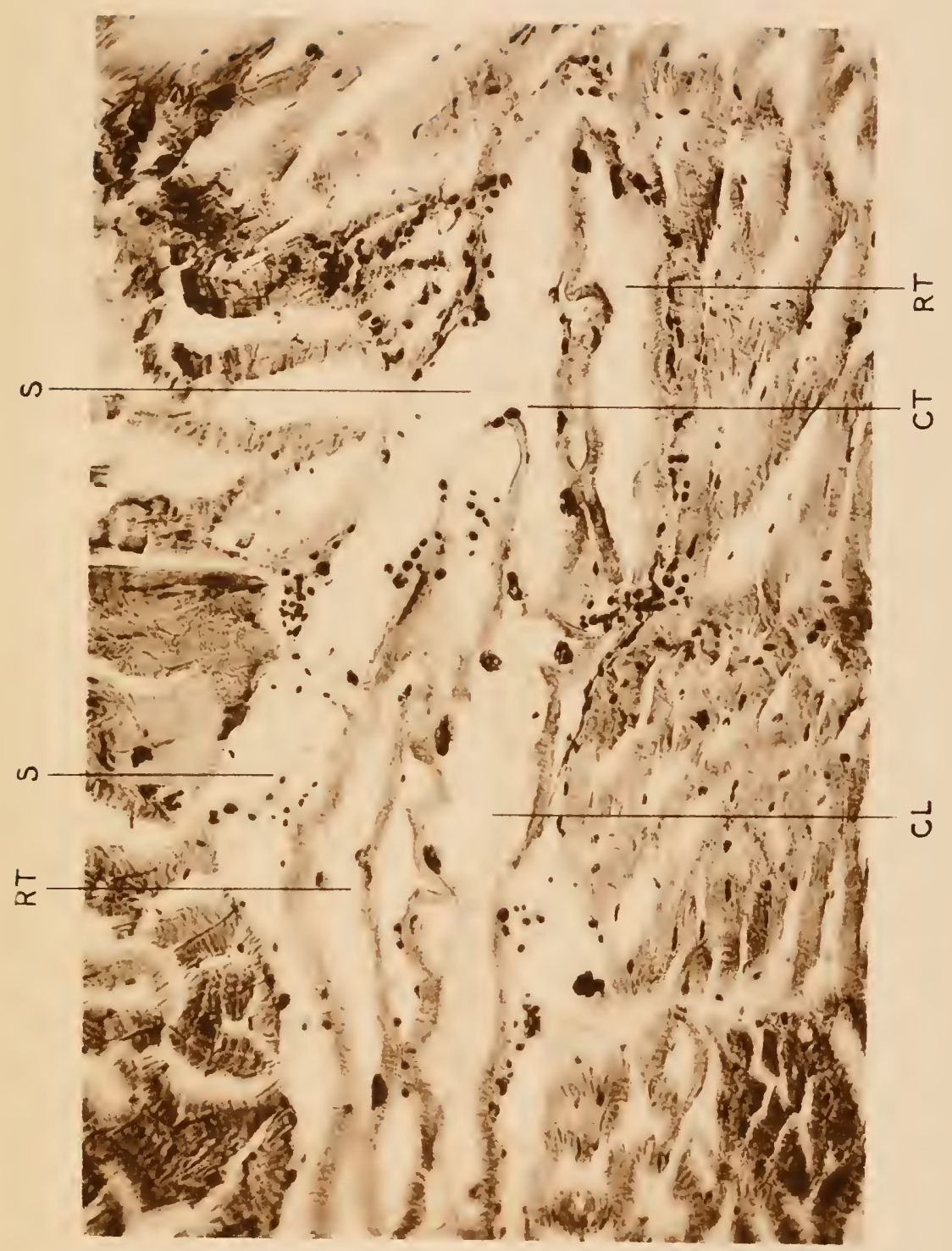

J. B. Obernetter, München, reprod.

cher in Jena. 


Zoolog. Jahrbücher Suppl. 14.

20

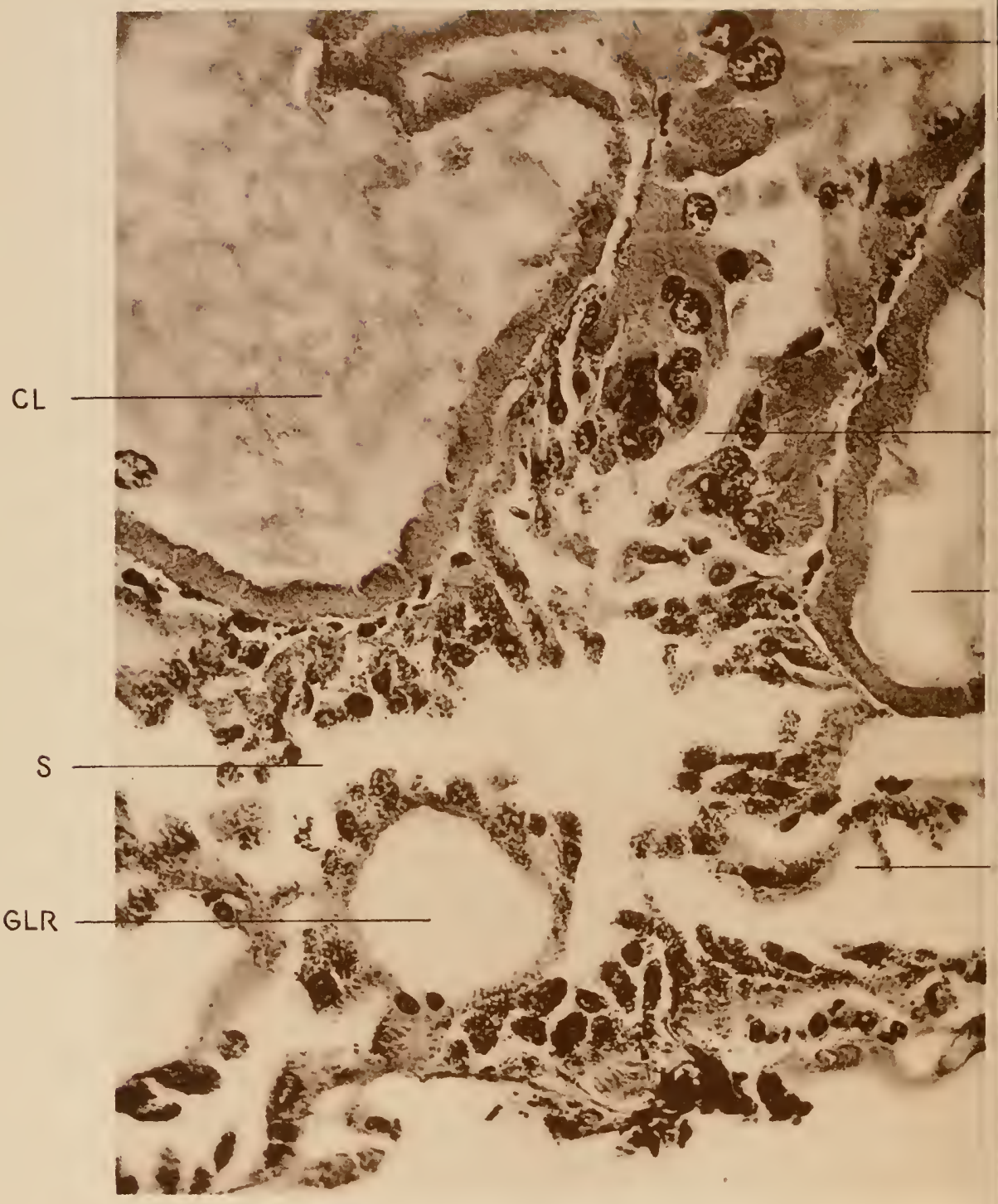

Buxton,

Verlag von Gustav Fis 
Taf. 20.

$\mathrm{CL}$

21

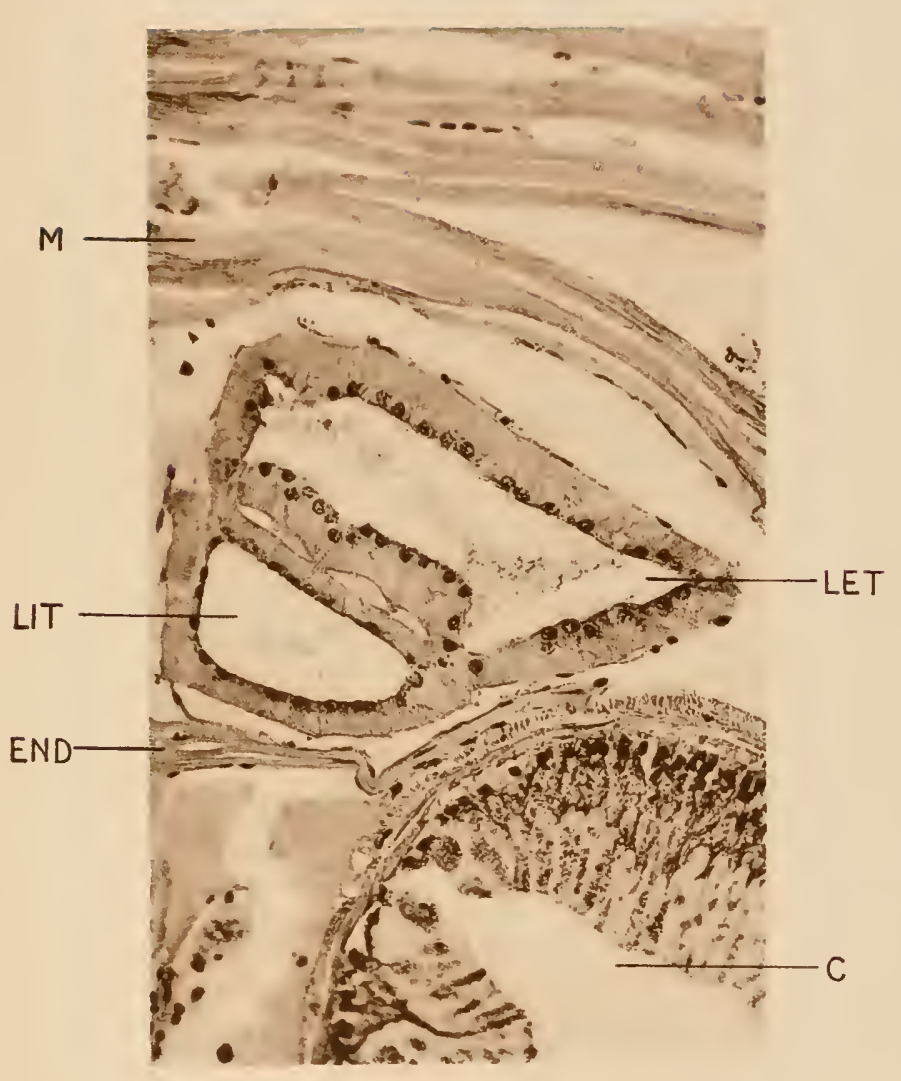

J. B. Obernetter, München, reprod.

r in Jena. 



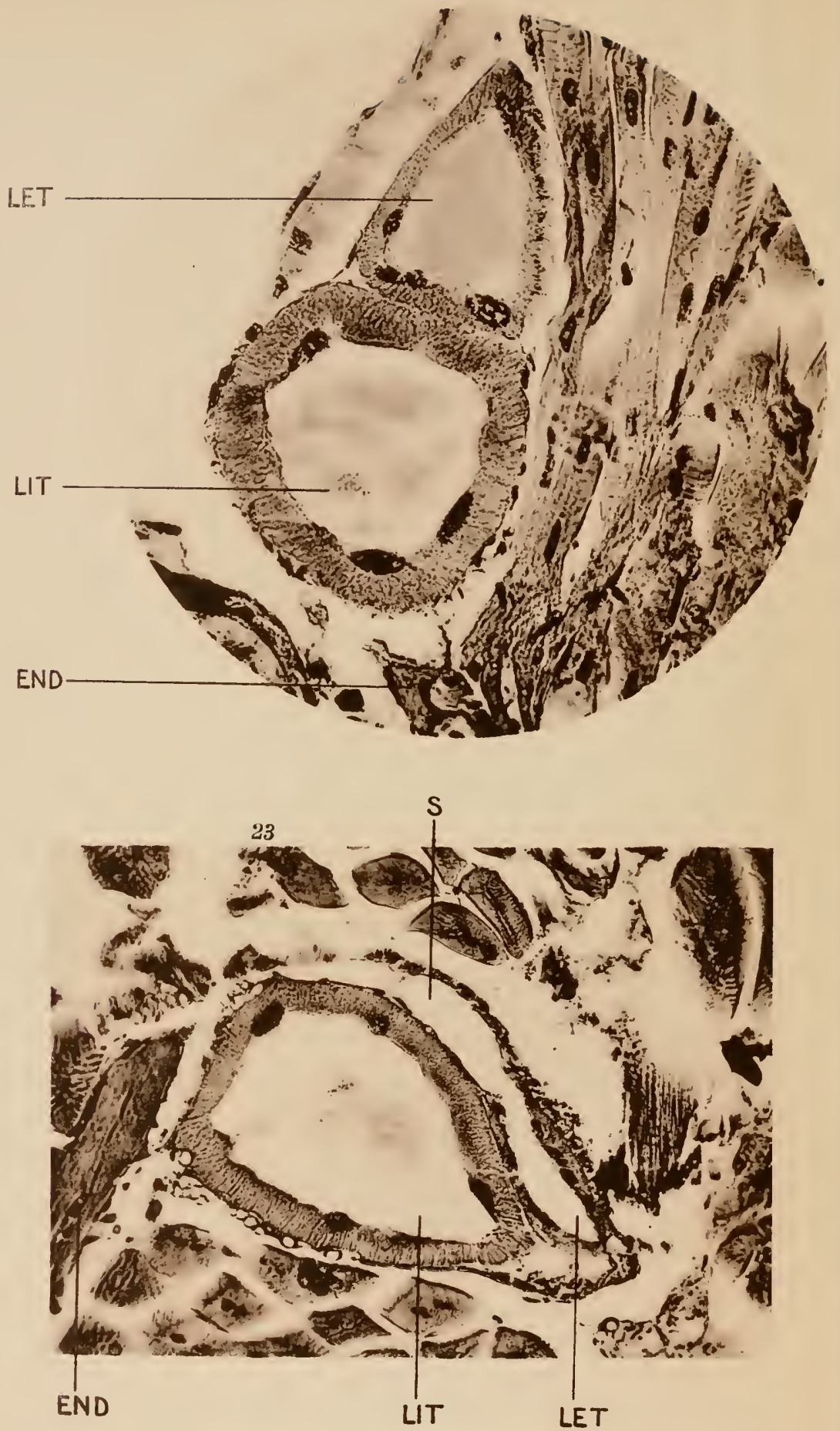
Taf. 21.

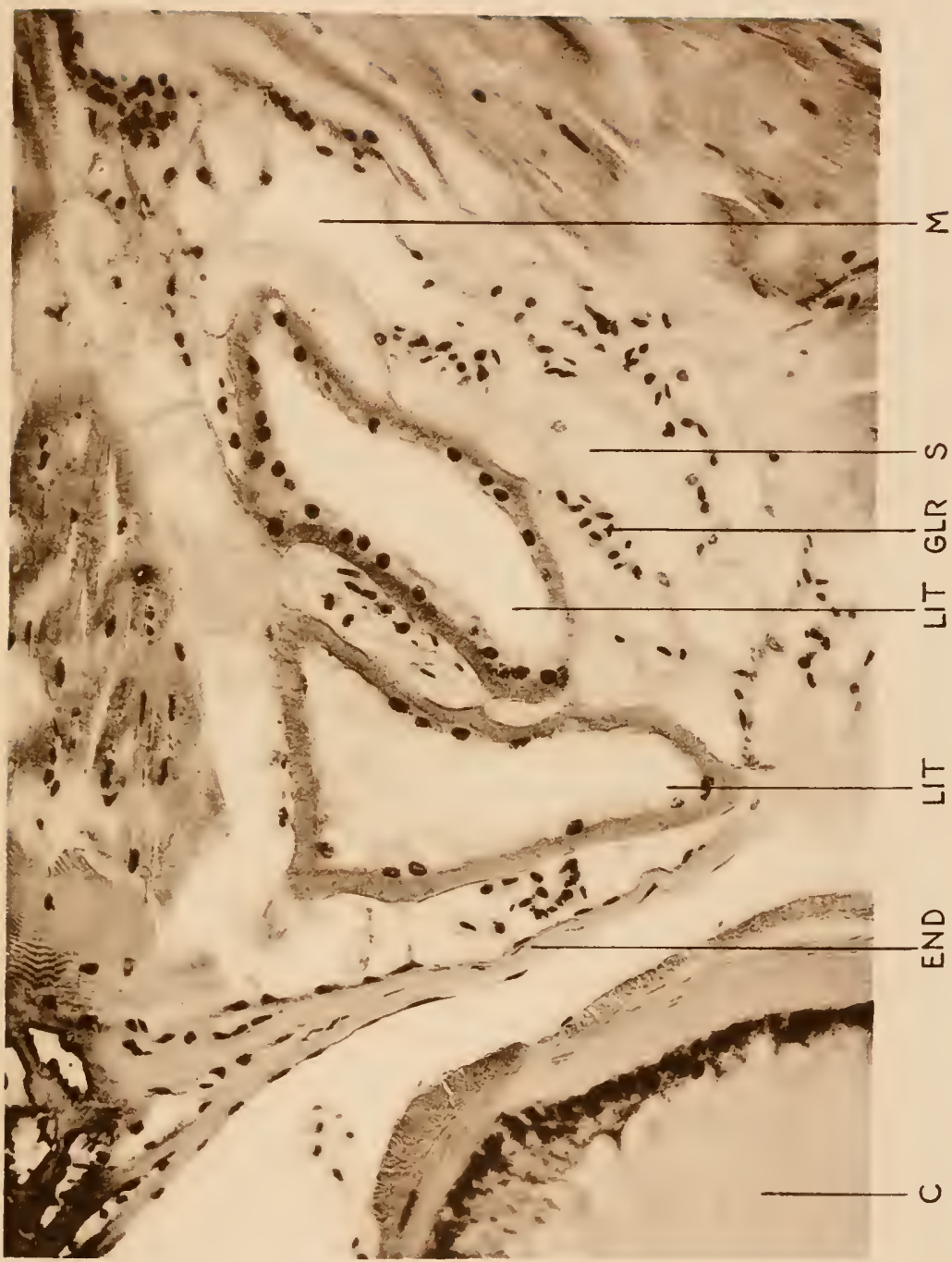

J. B. Obernษiter, München, reprod. 


Zoolog. Jahrbücher Suppl. 14.

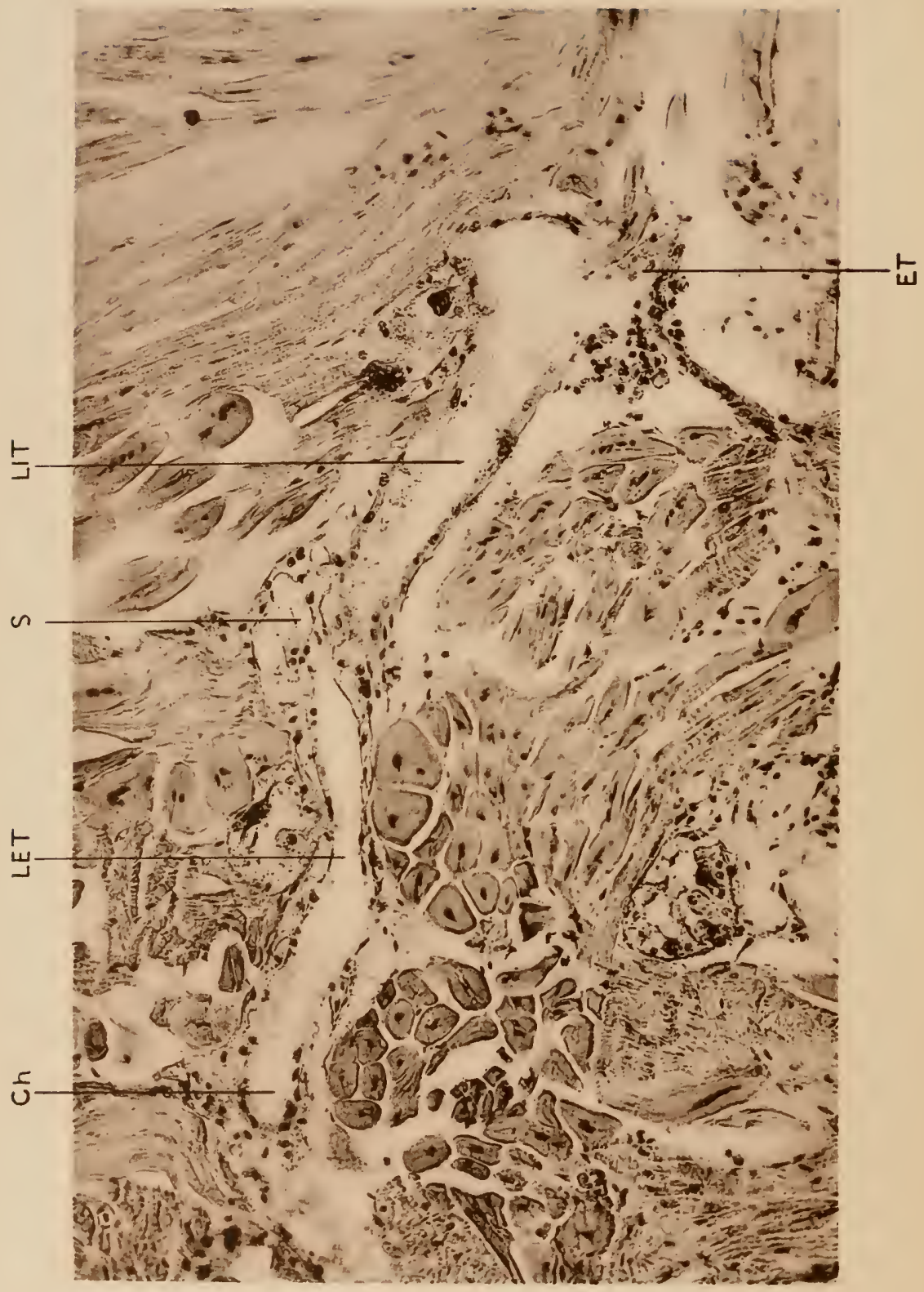

Buxton. 
Taf. 22.

$25 a$

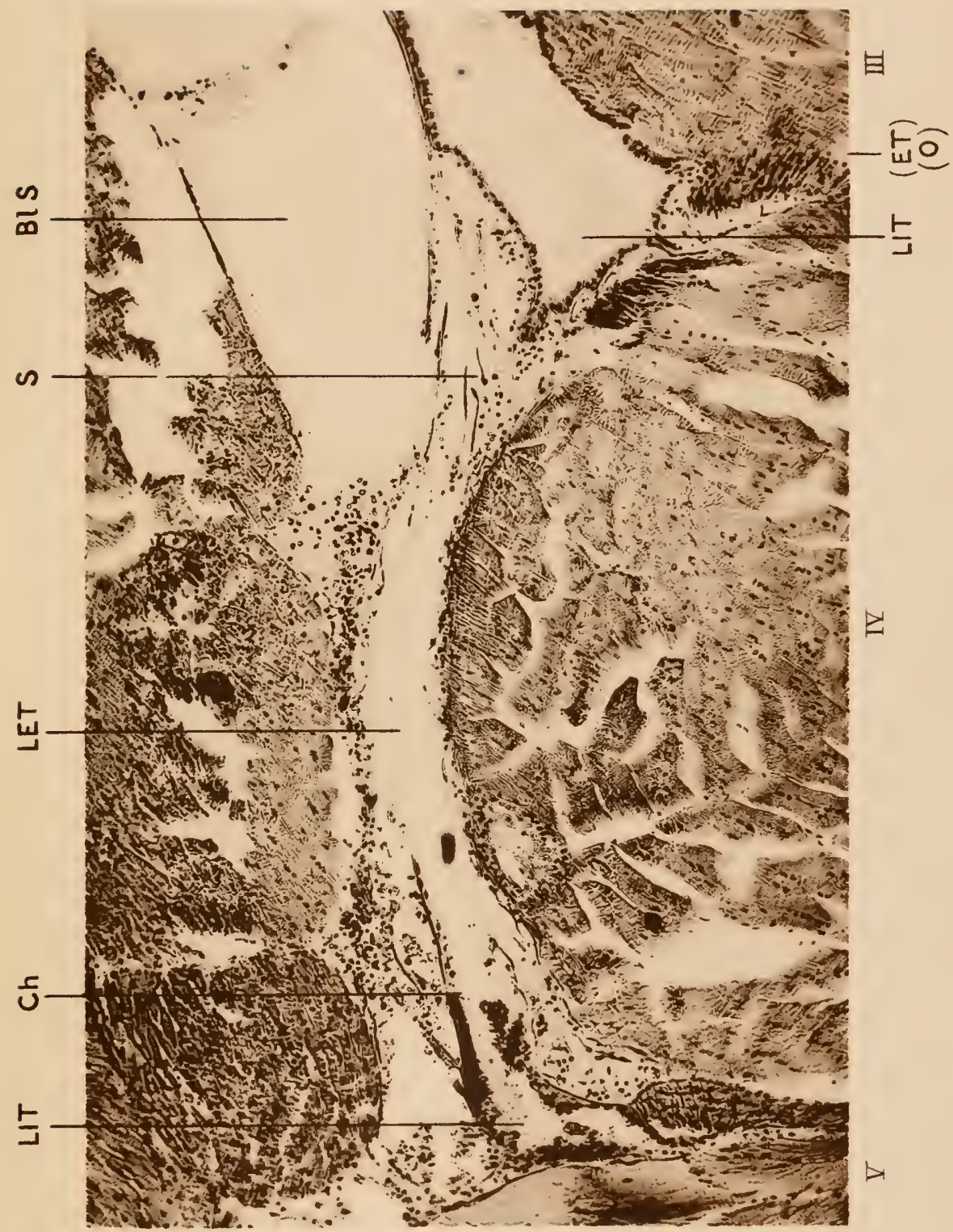

J. B. Obernetter, München, reprod. 


Zoolog. Jahrbücher Suppl. 14.
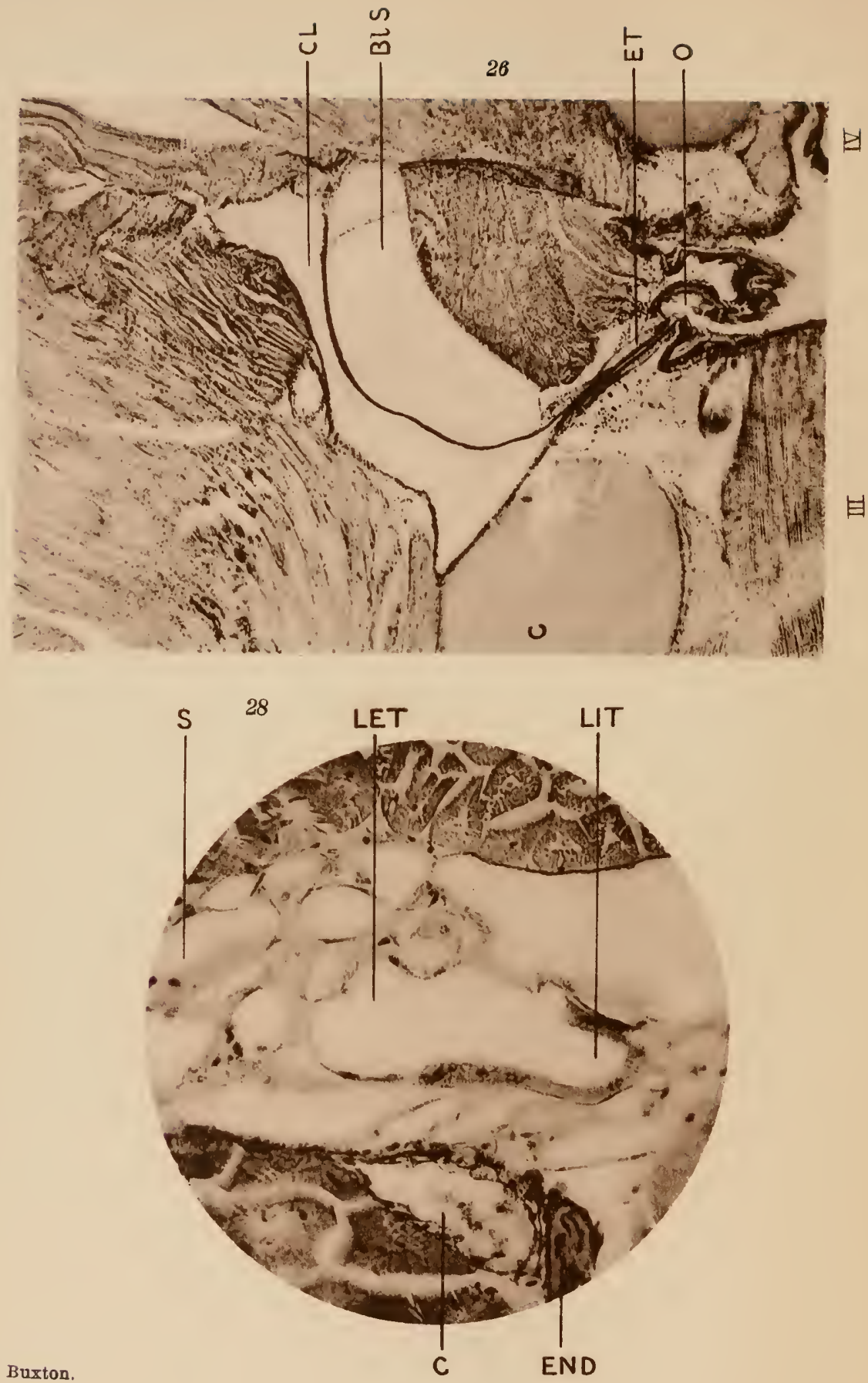

Verlag von Gust 
Taf. 23.

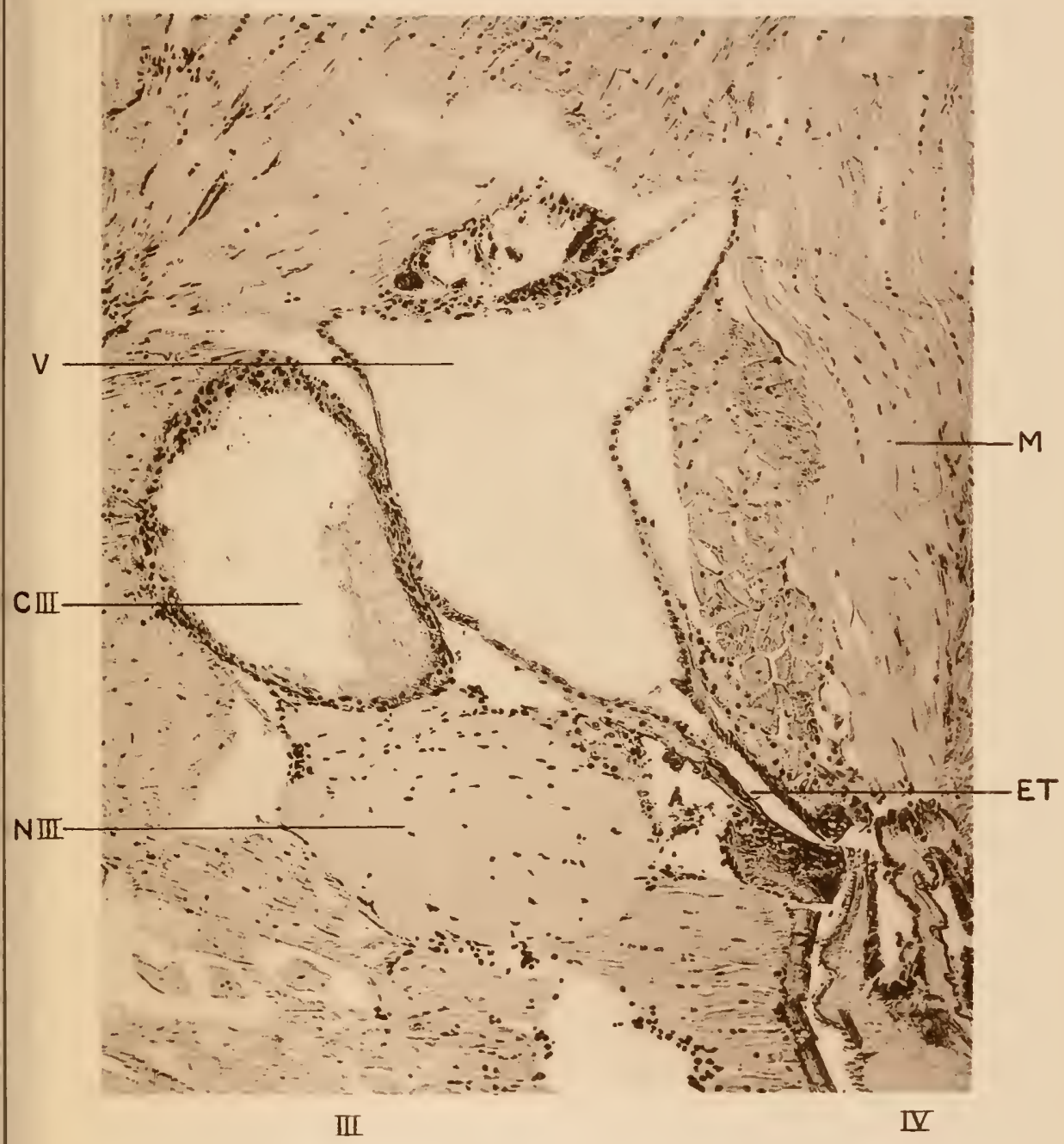

J, B. Obernetter, München, reprod.

Fischer in Jena. 




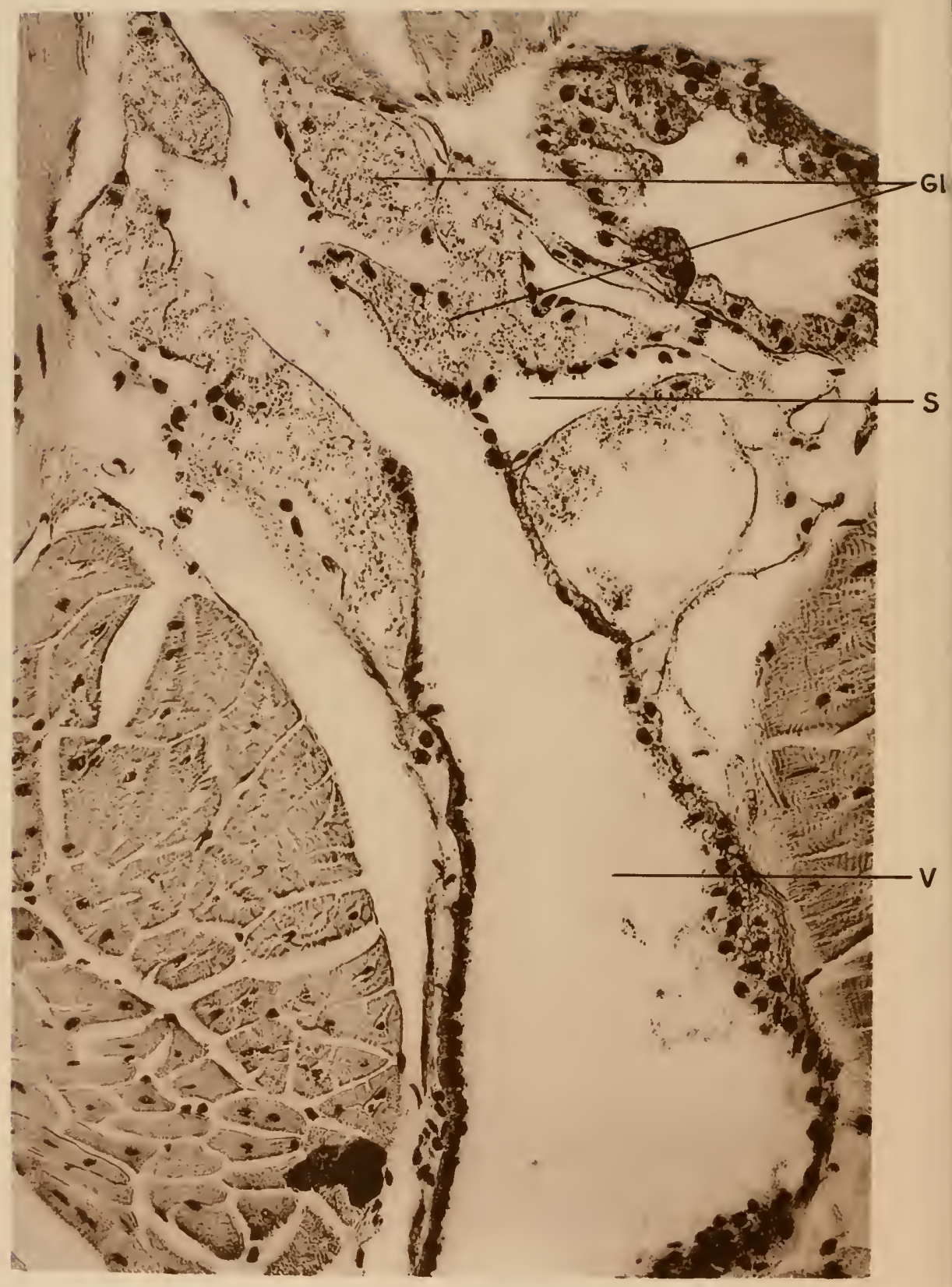

(E.T.) 


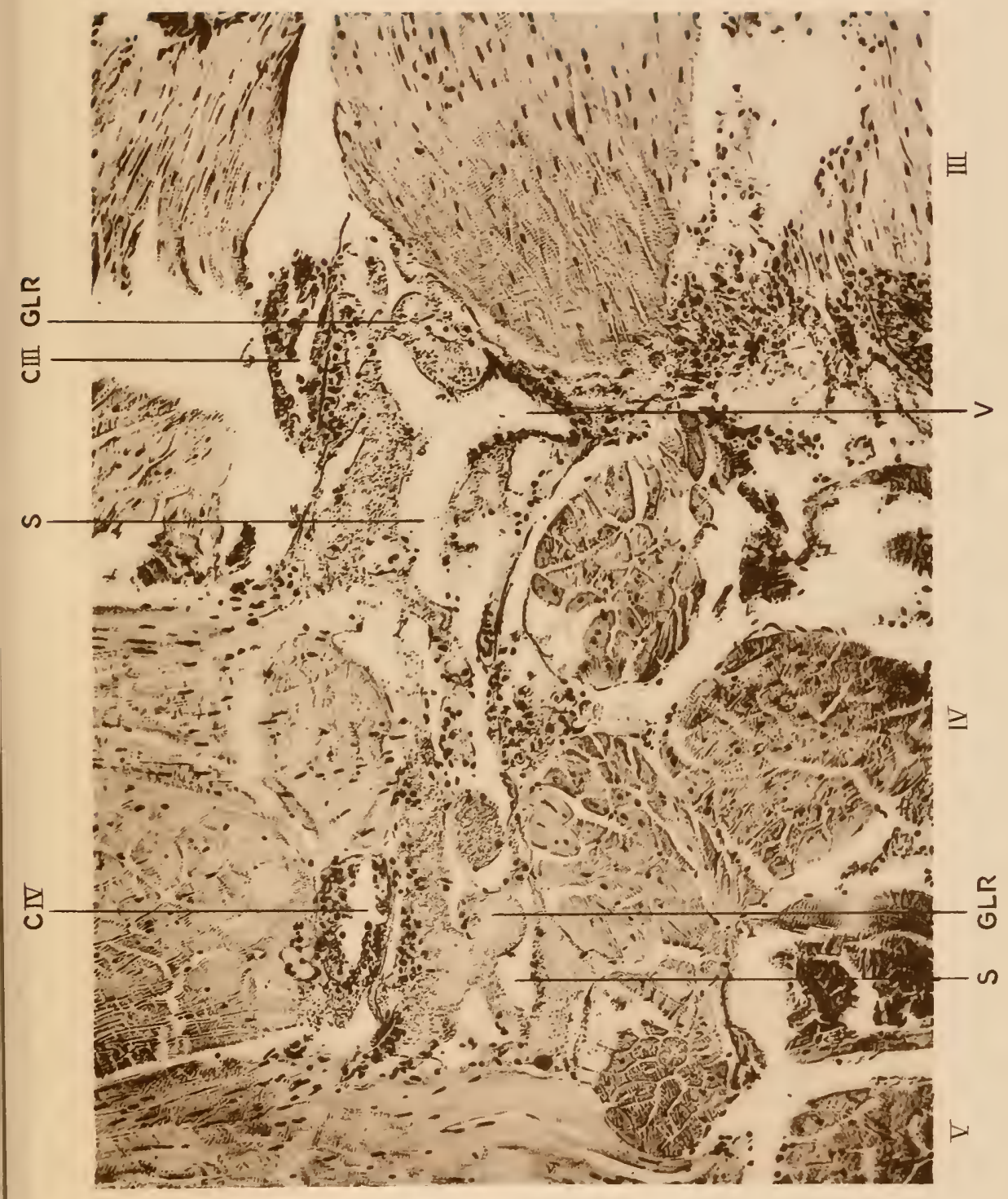

J. B. Obernetter, München, reprod.

Fischer in Jena. 




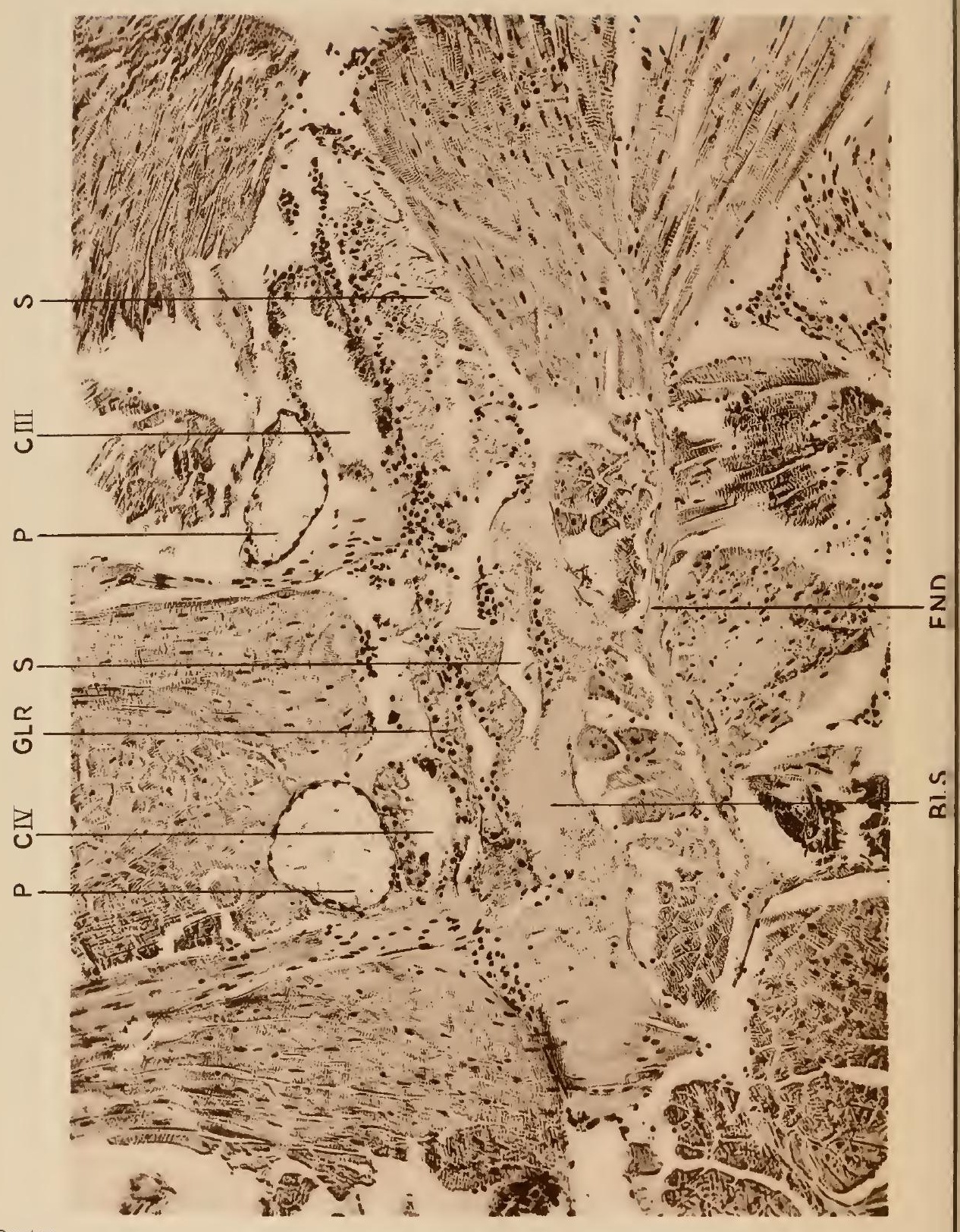

Buxton. 
Taf. 25.

30

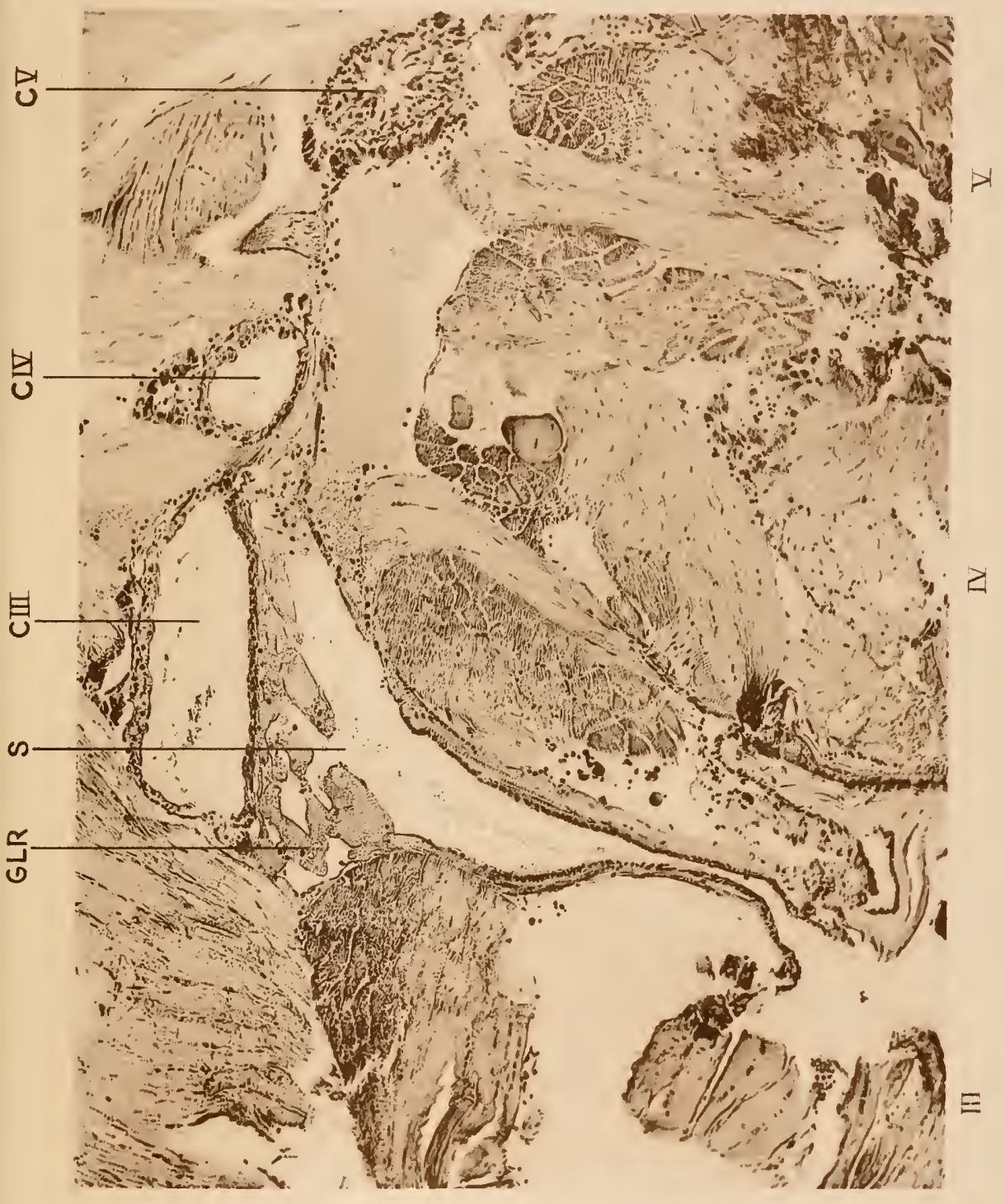

J. B. Obernetter, München, reprod.

$\boldsymbol{r}$ in Jena. 


Zoolog. Jahrbücher Suppl. 14.

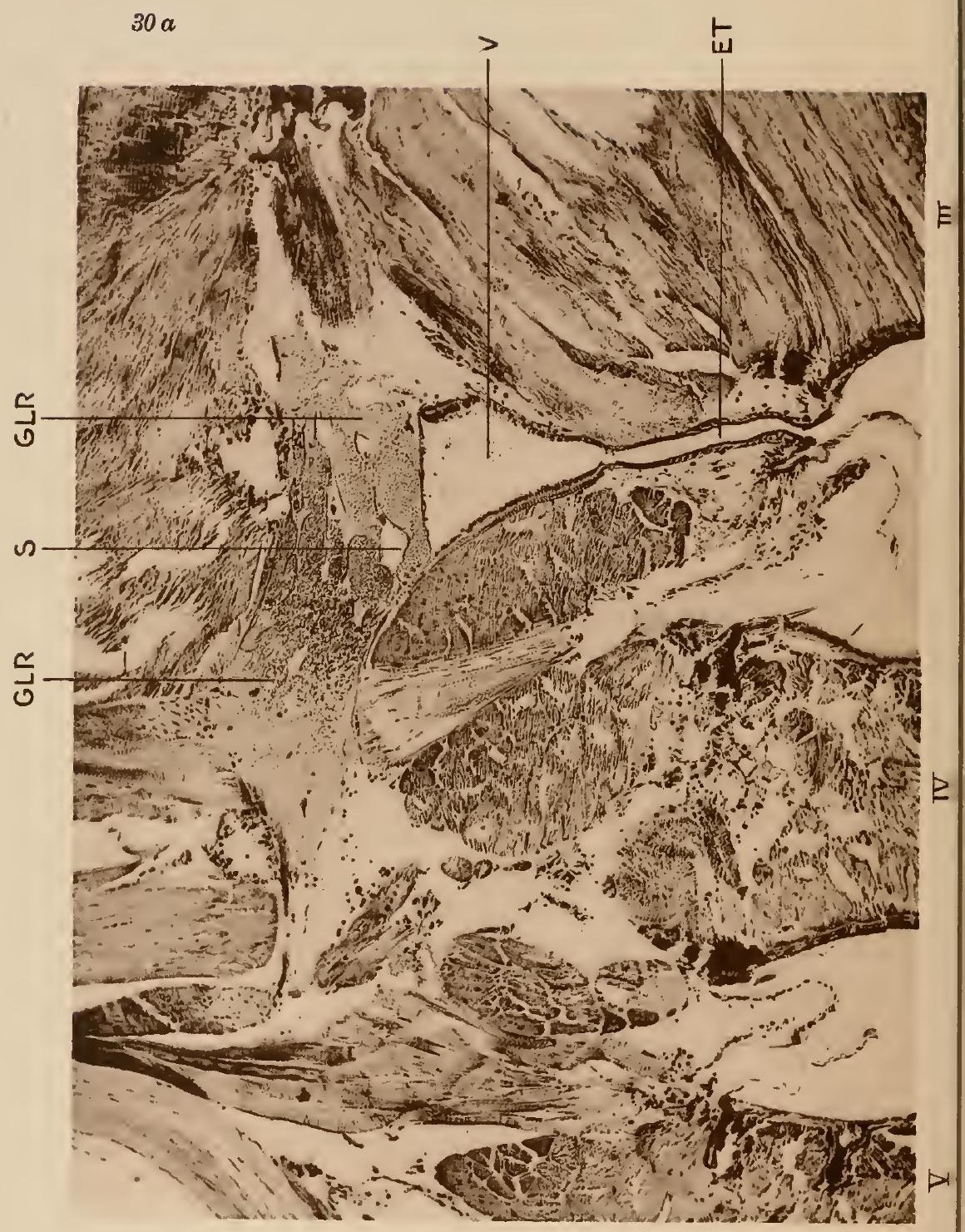

Buxton.

Verlag von $\boldsymbol{G}$ 
Taf. 26.
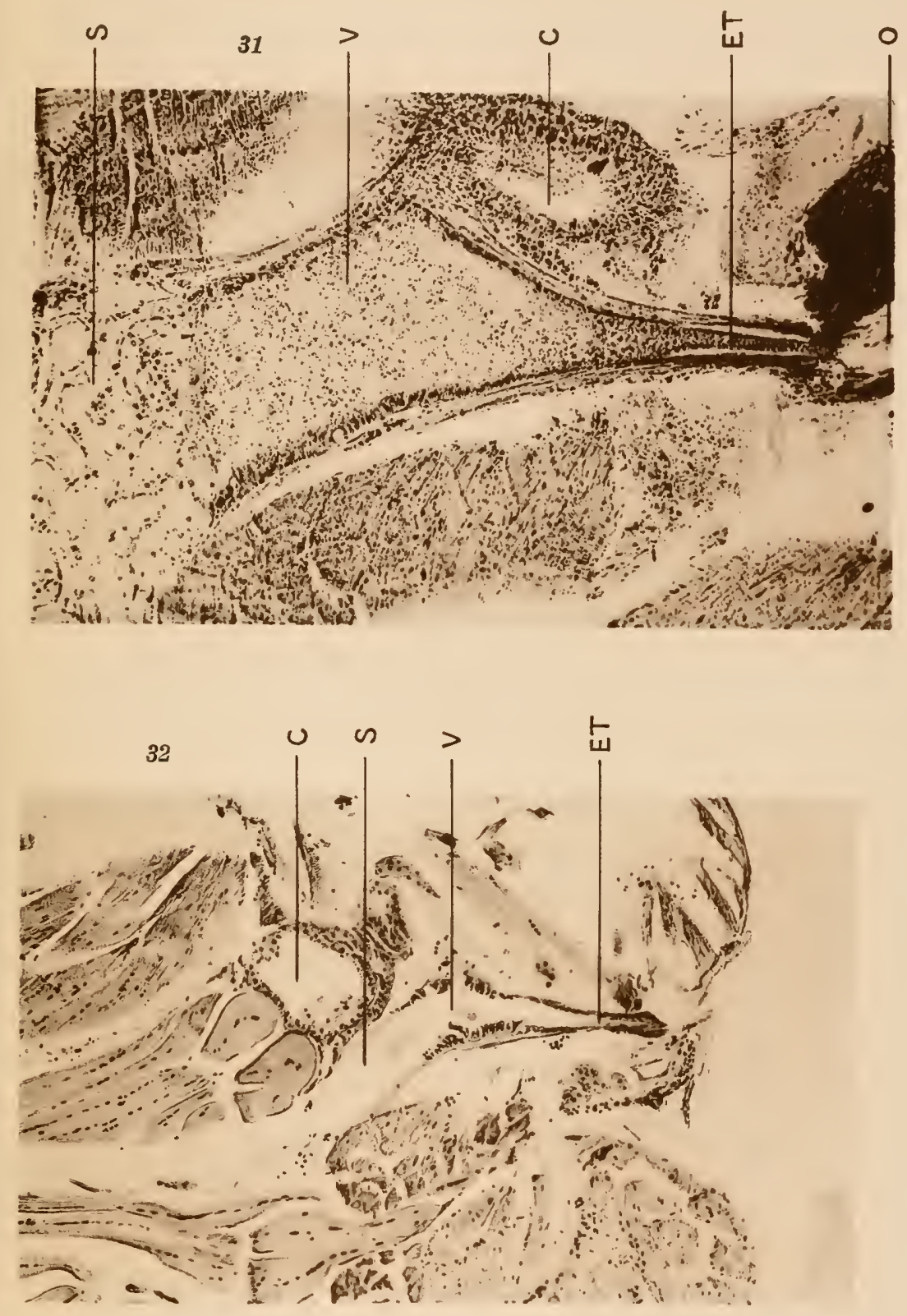

J. B. Obernetter, München, reprod.

iv Fischer in Jena. 




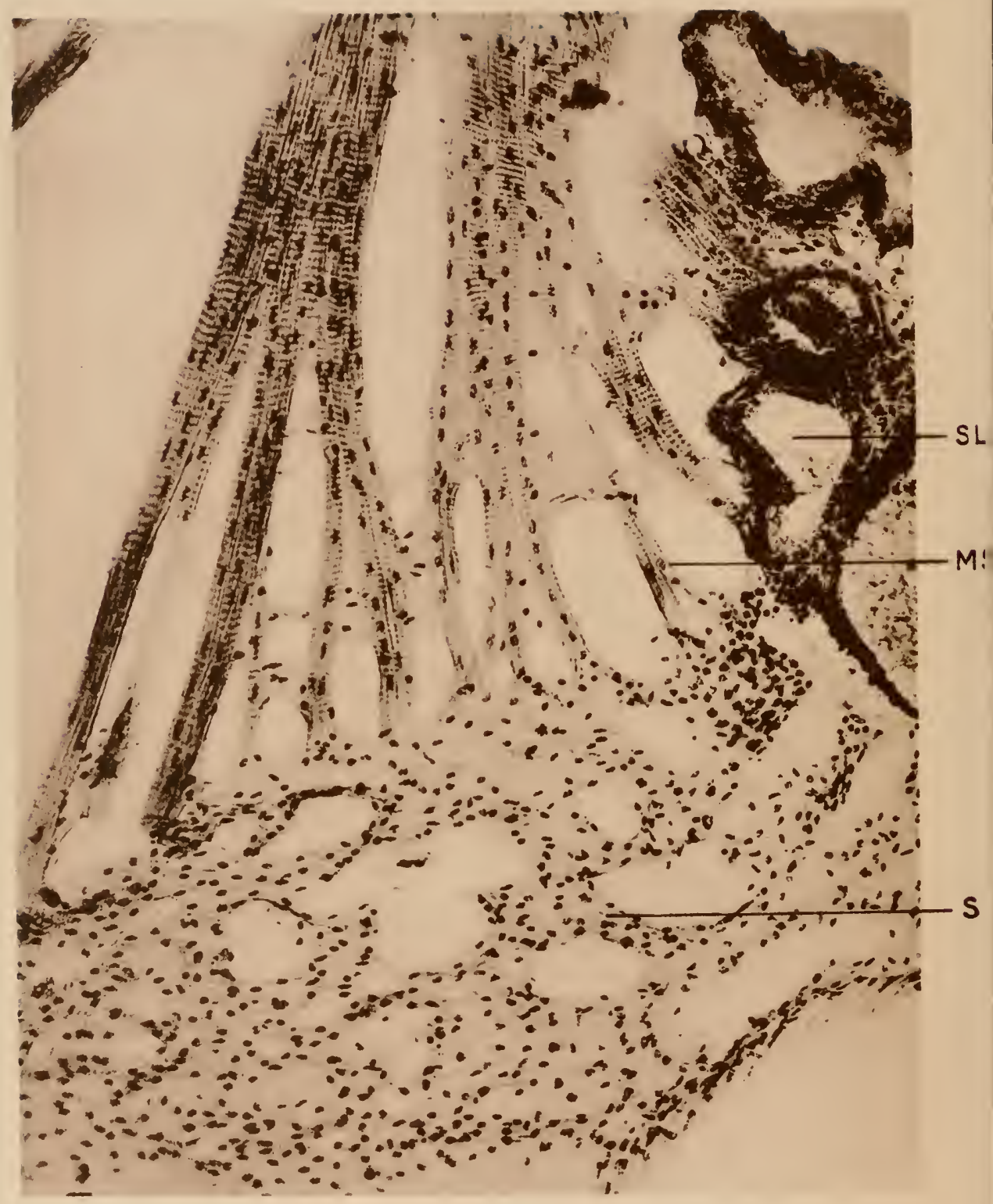




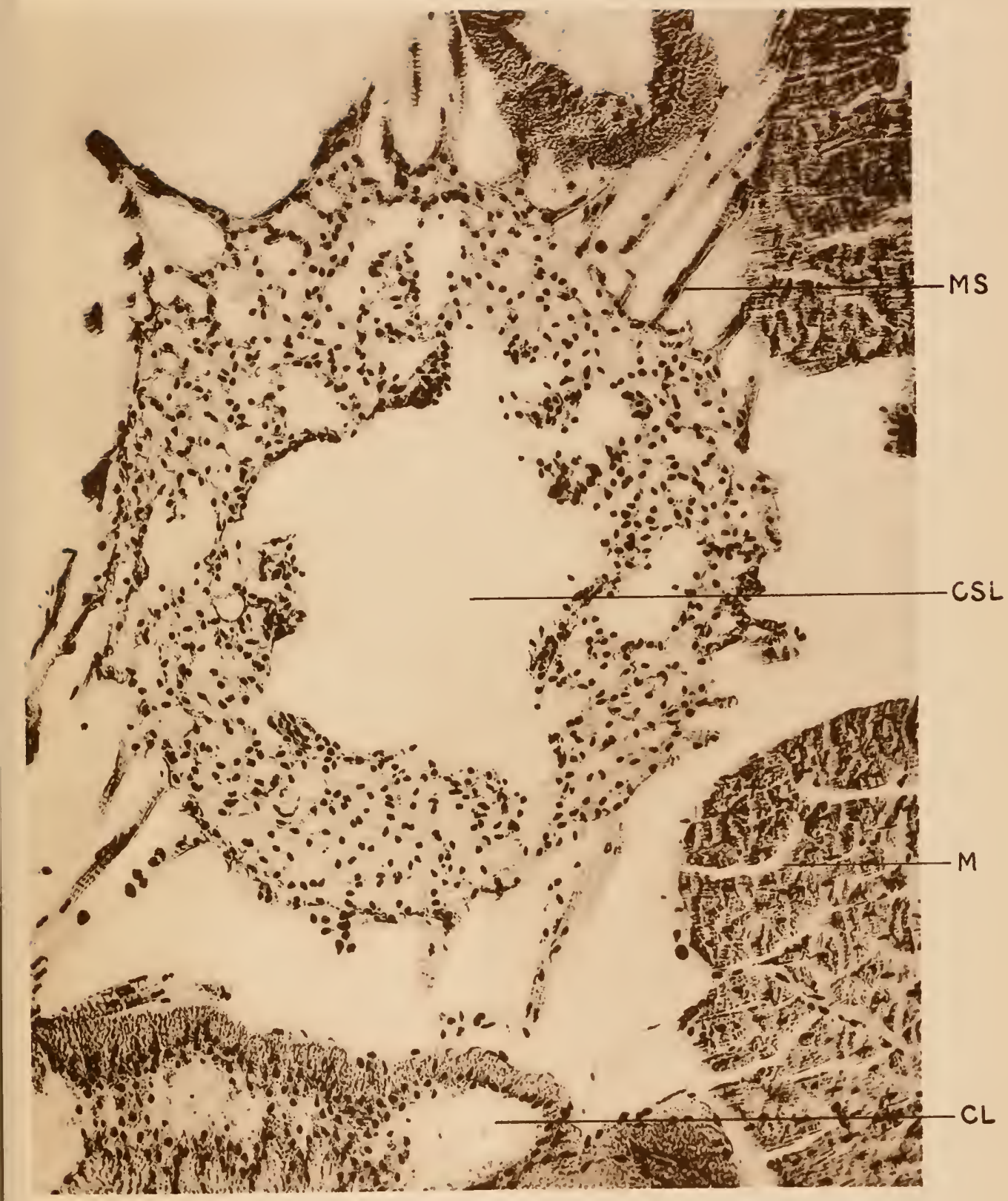

J. B. Obernetter, München, reprod,

:her in Jena. 


( 


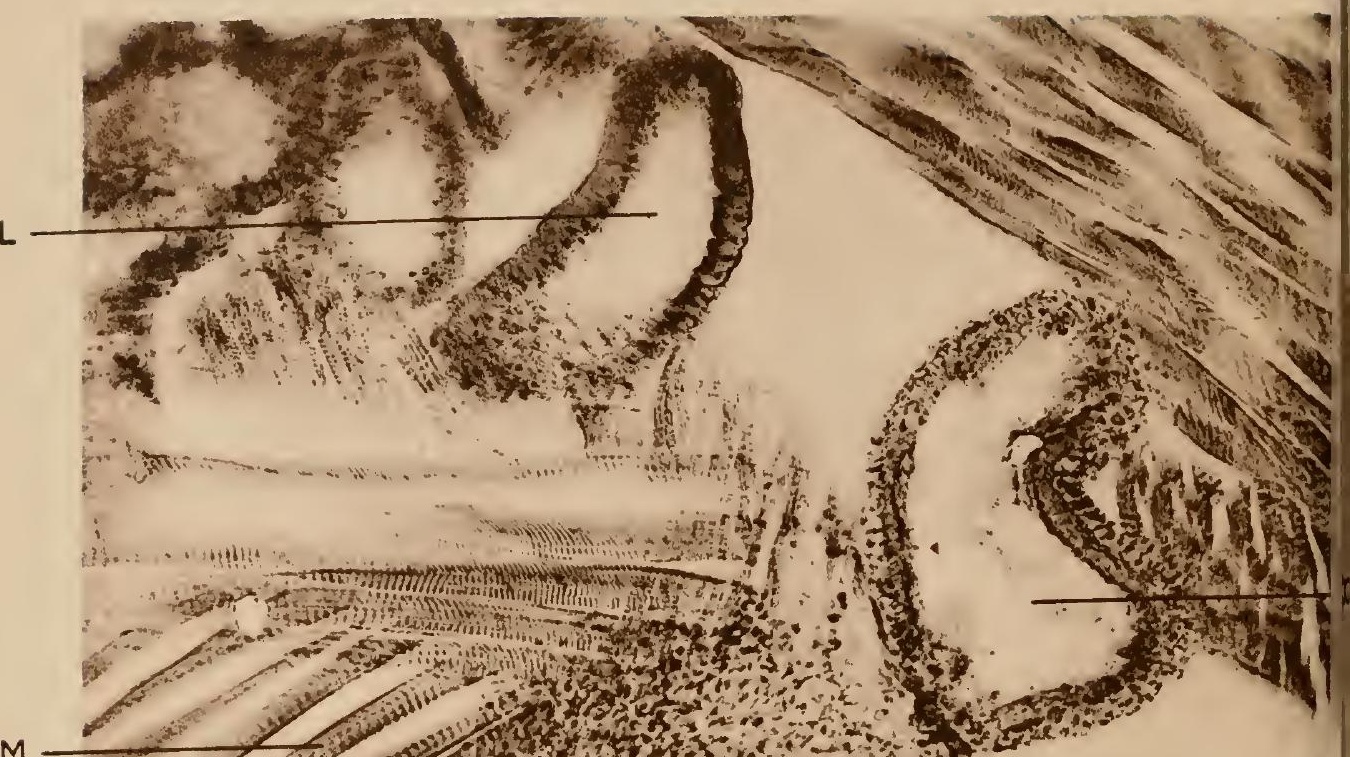

$M$
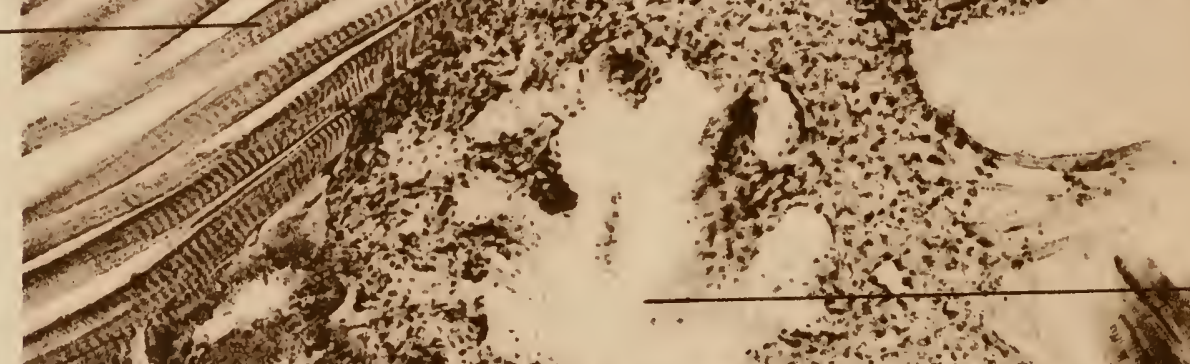

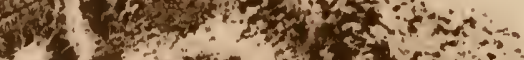

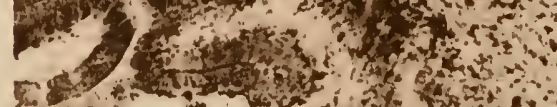

5.

is $\Rightarrow+2=2$

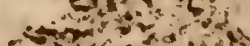

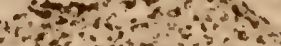

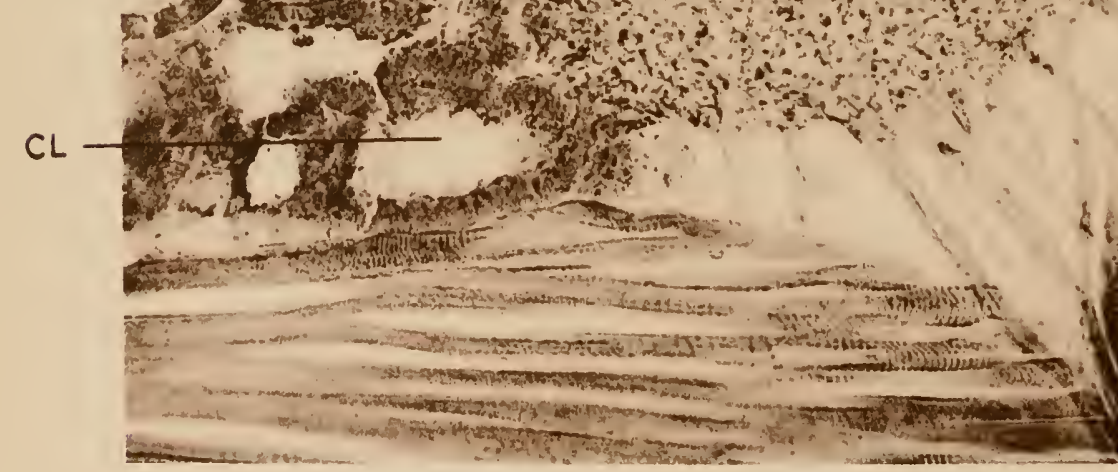

Buxton. 


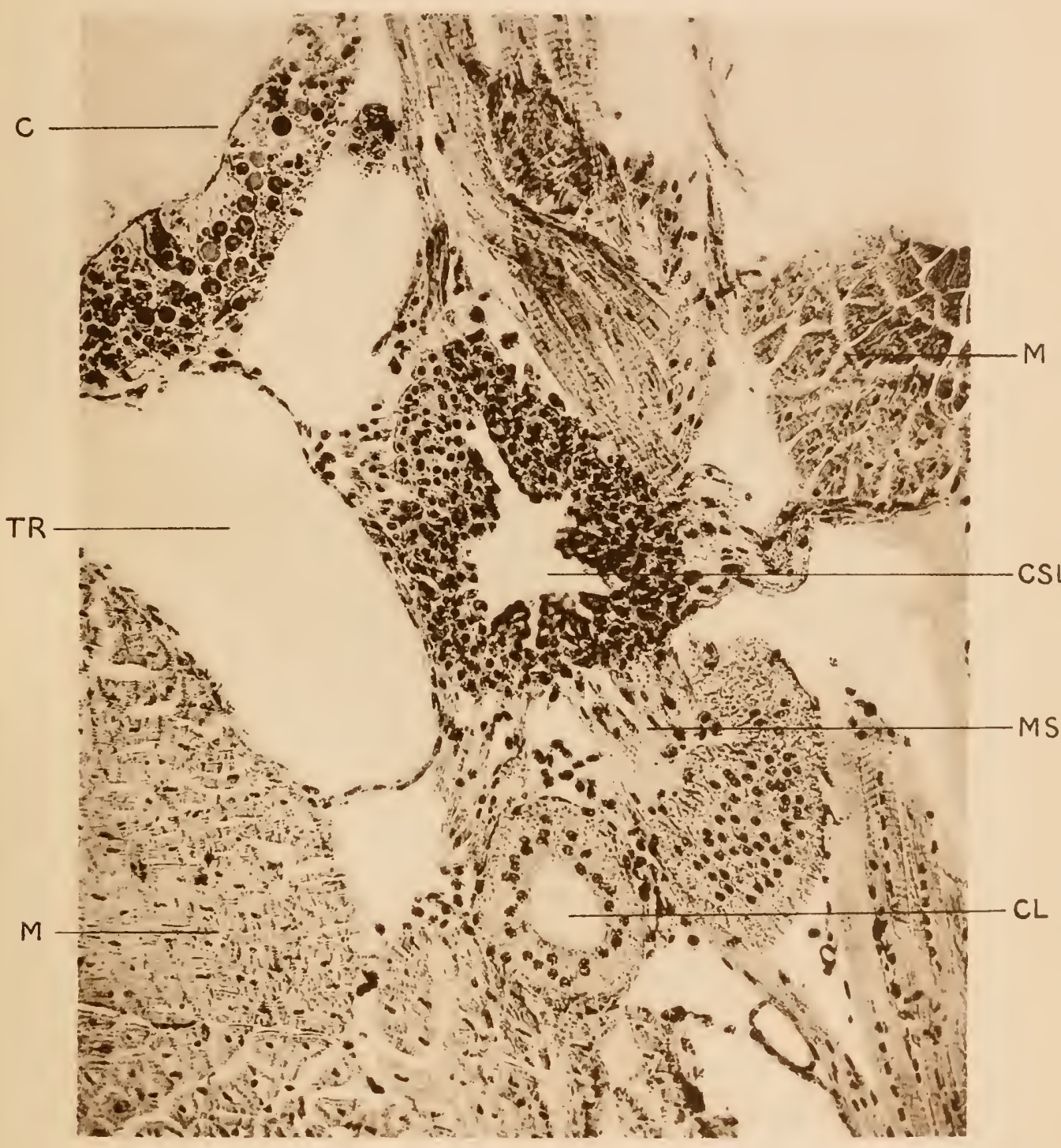




Zoolog Jahrbücher Suppl. 14.

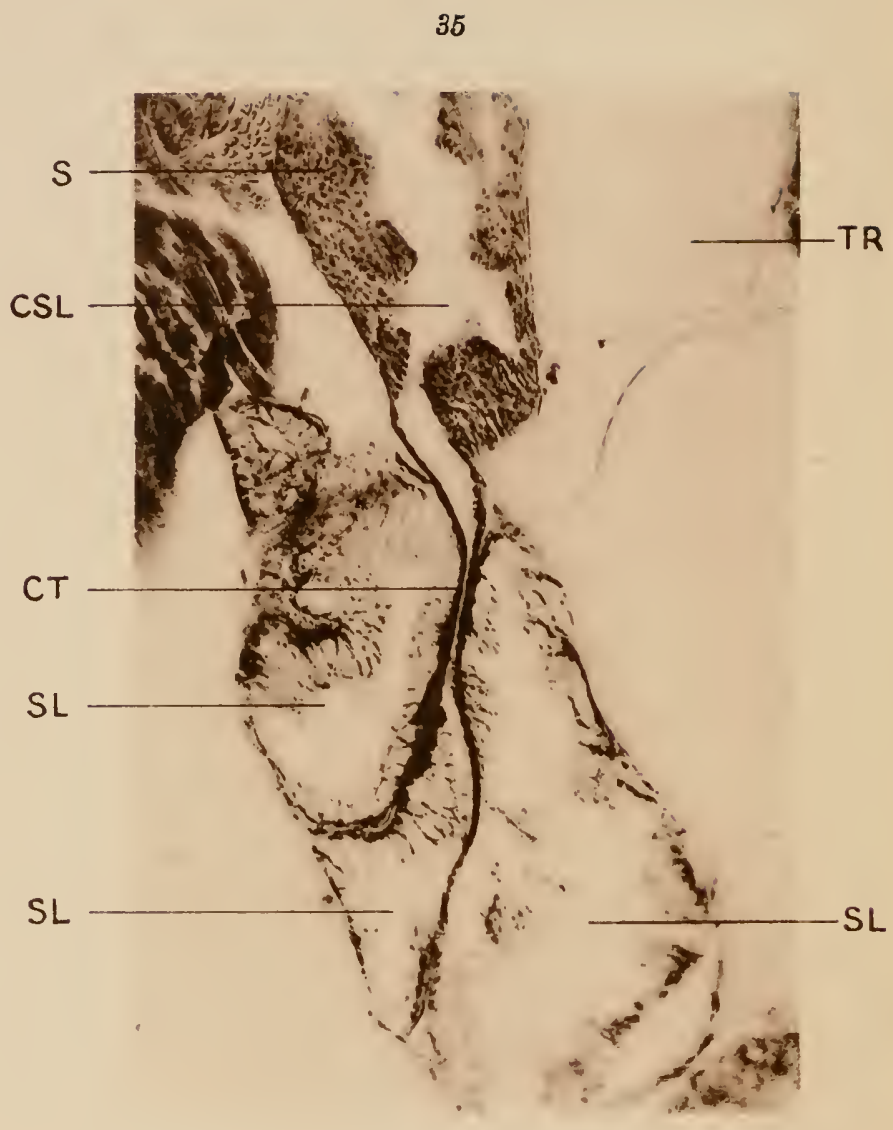

Buxton. 
Taf. 29.
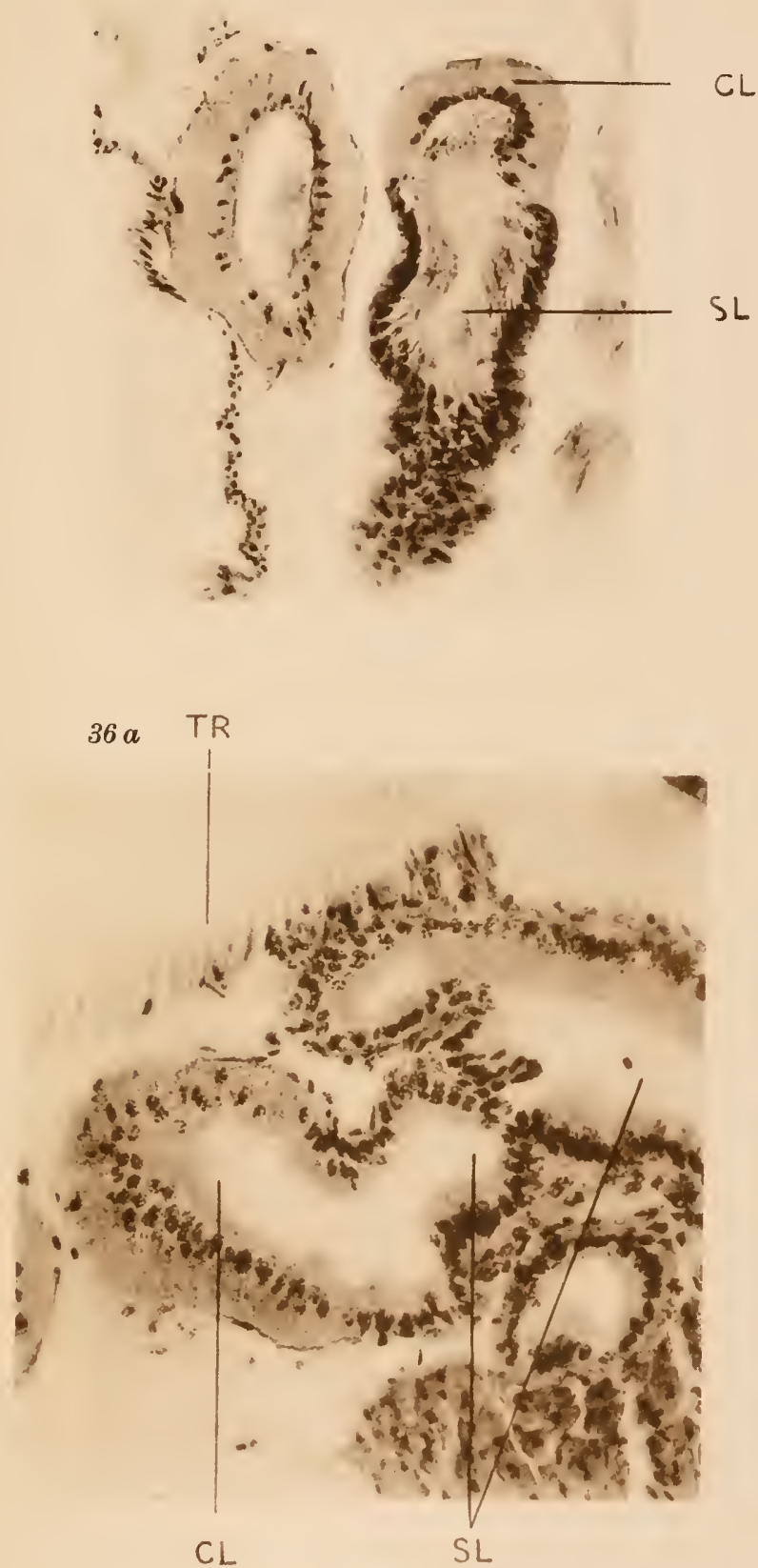

J. B. Obernetter, München, reprod.

Fischer in Jena. 

<smiles>C1CCCC1</smiles> 
Zoolog. Jahrbücher Suppl. 14.

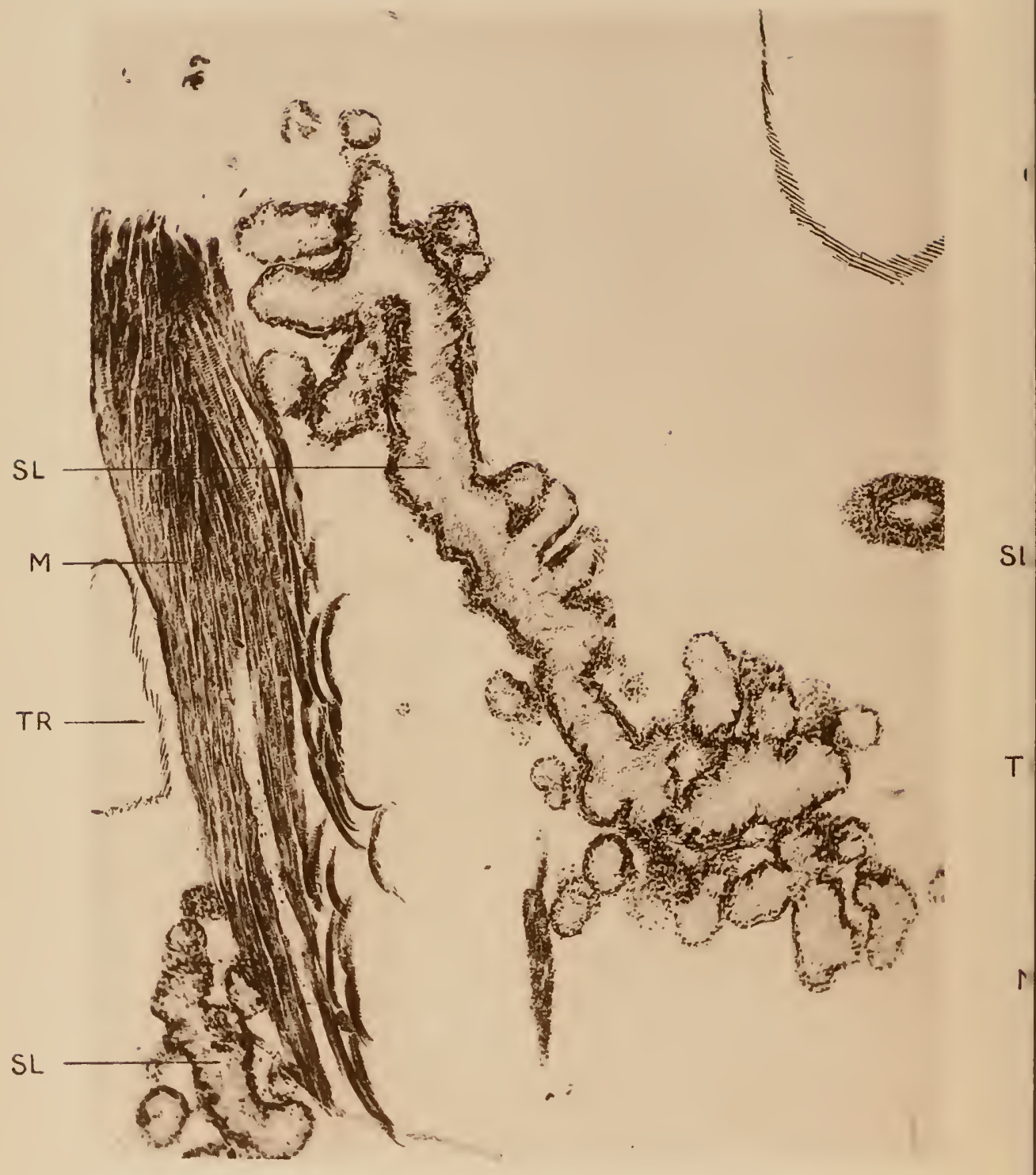

Buxton, 
Taf. 30.

$37 a$

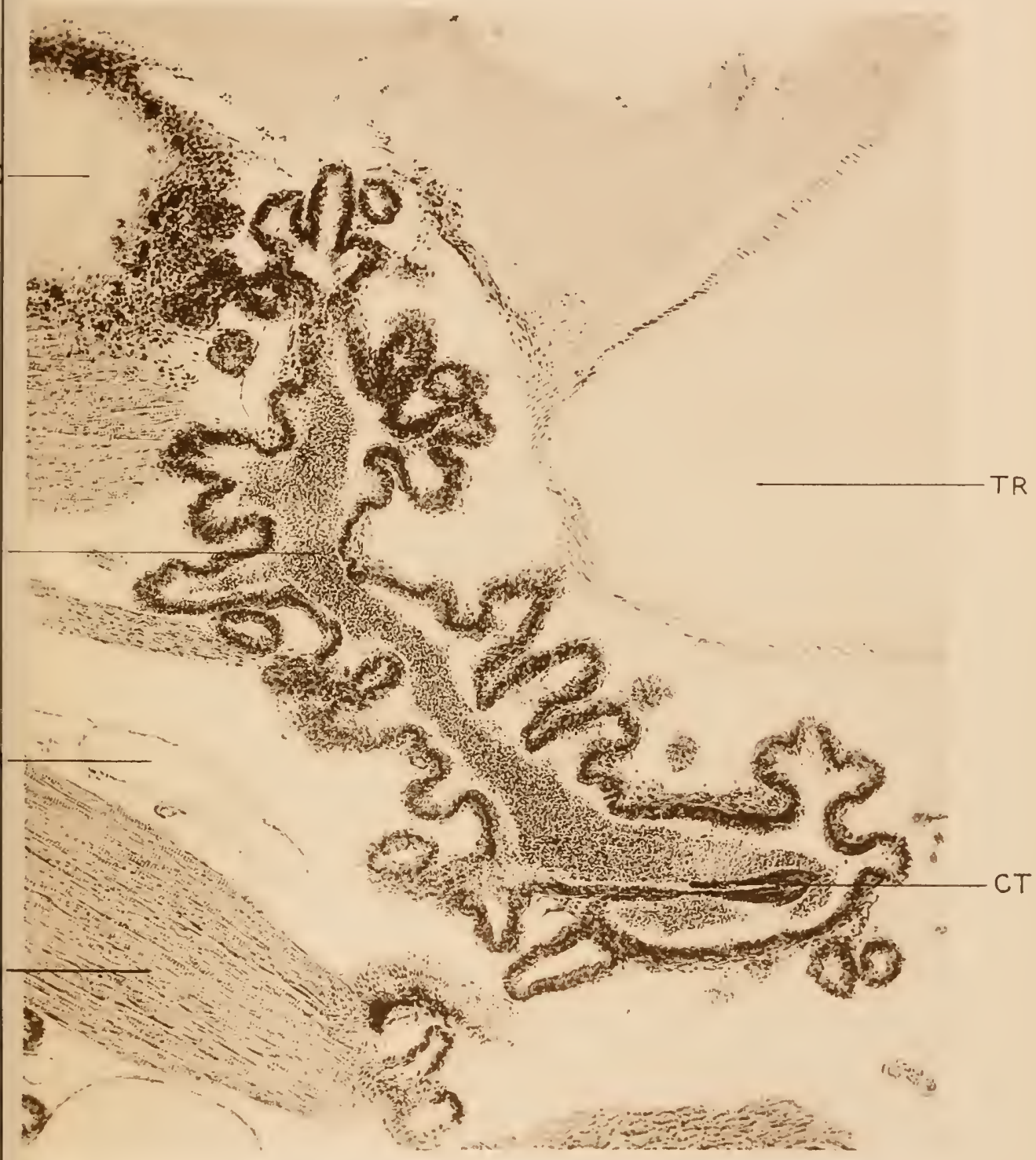

J. B. Obernetter, München, reprod.

, Fischer in Jena. 

Zoolog. Jahrbücher Suppl. 14.

38

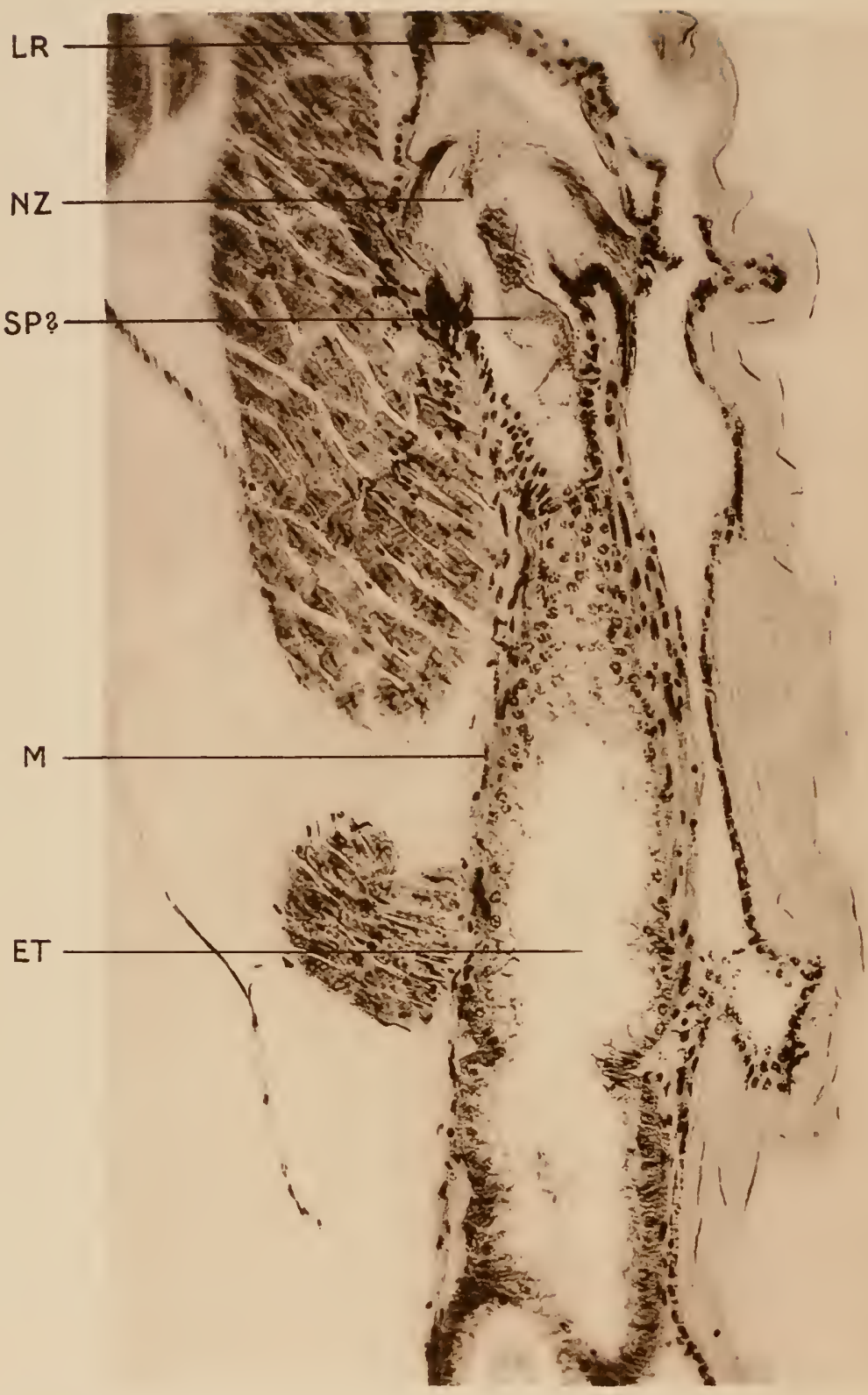

Buxton.

Verlag von Gustav ] 
Taf. 31.

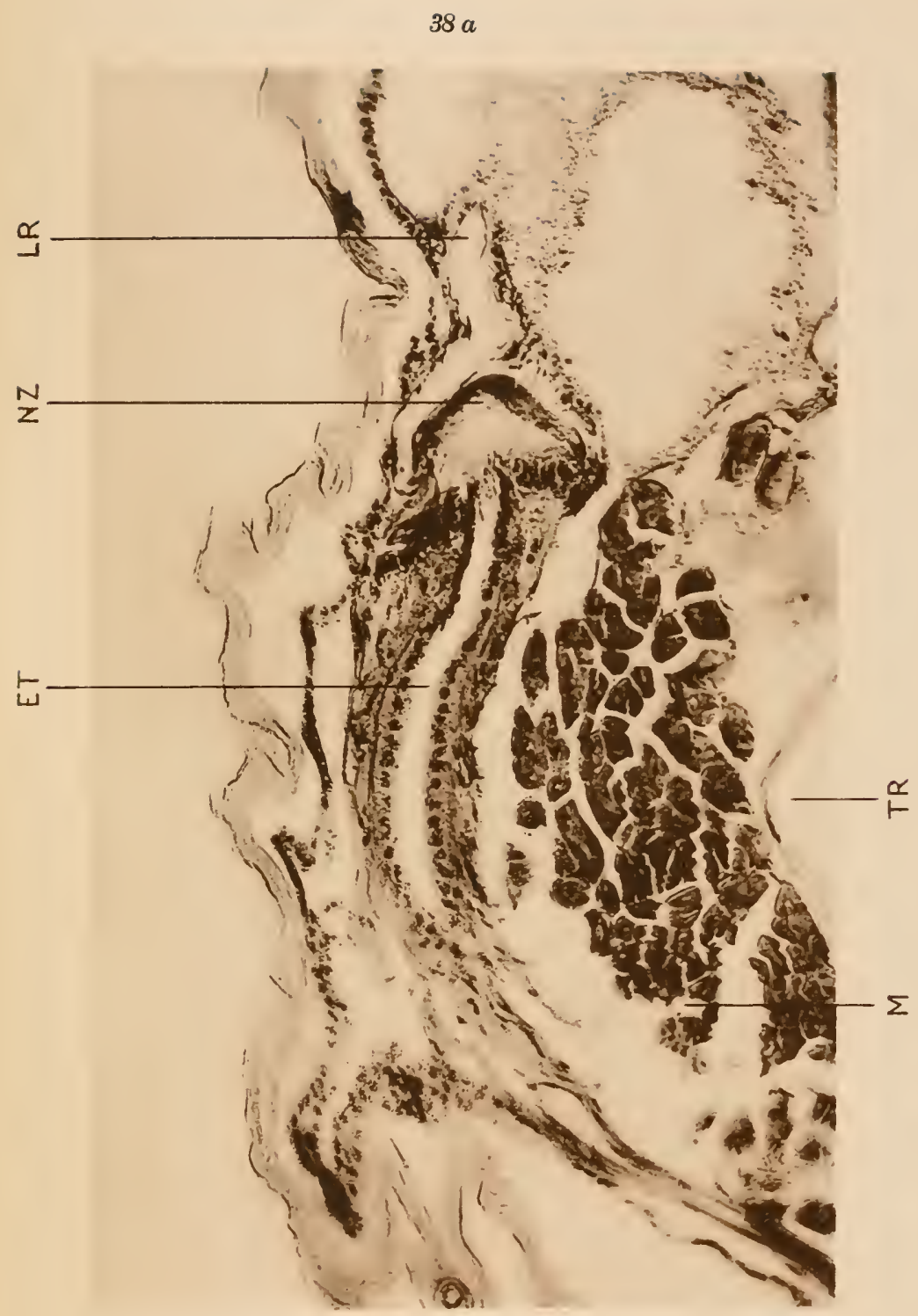

J. B. Obernetter, München, reprod, her in Jena. 


Zoolog. Jahrbücher Suppl. 14.

386

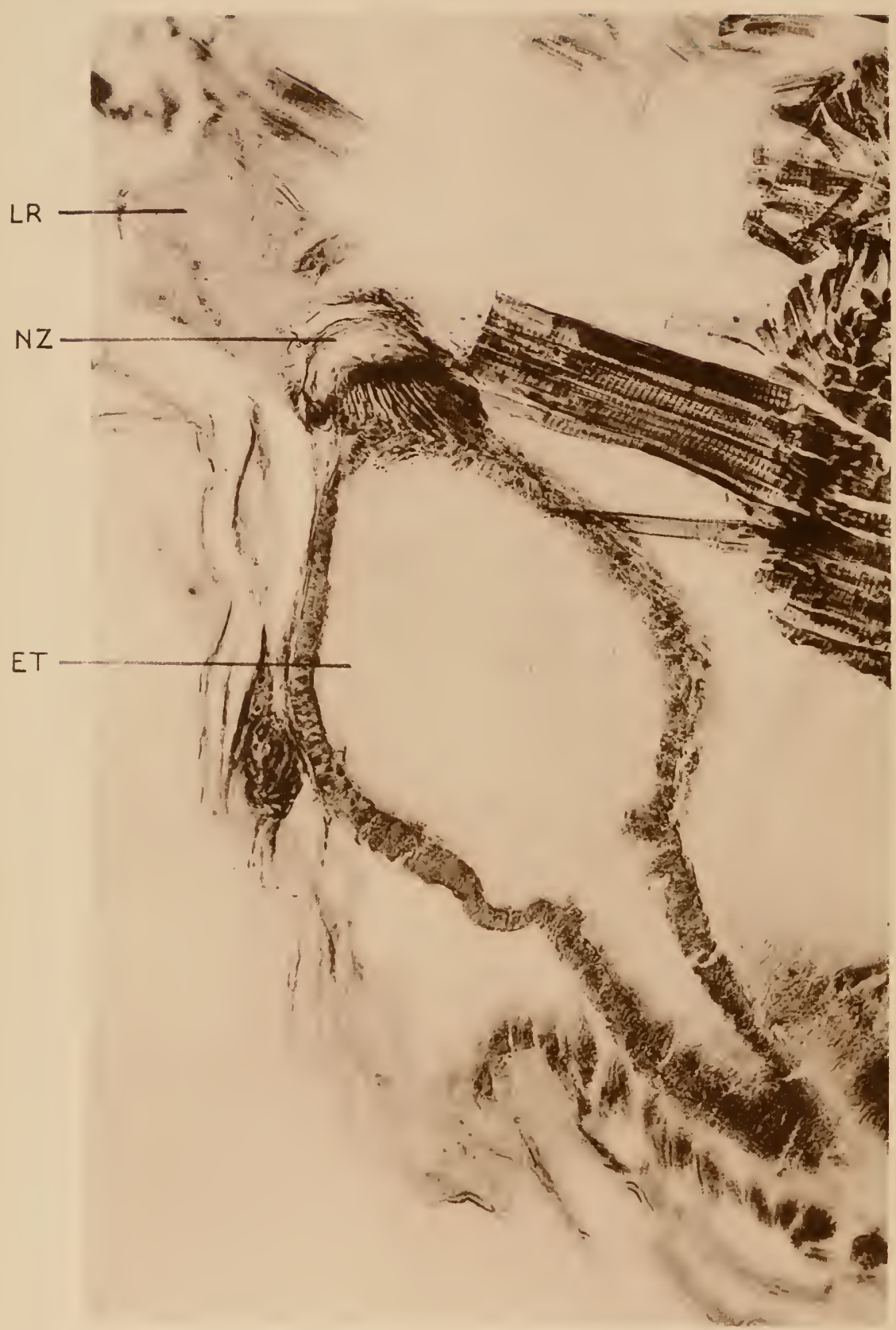

R

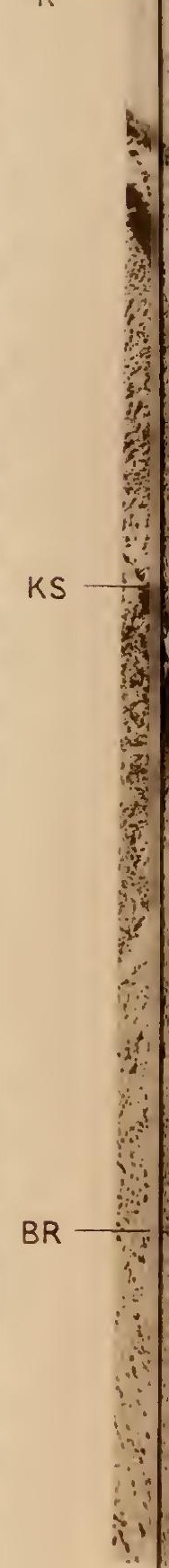

Buxton,

Verlag von Gus 


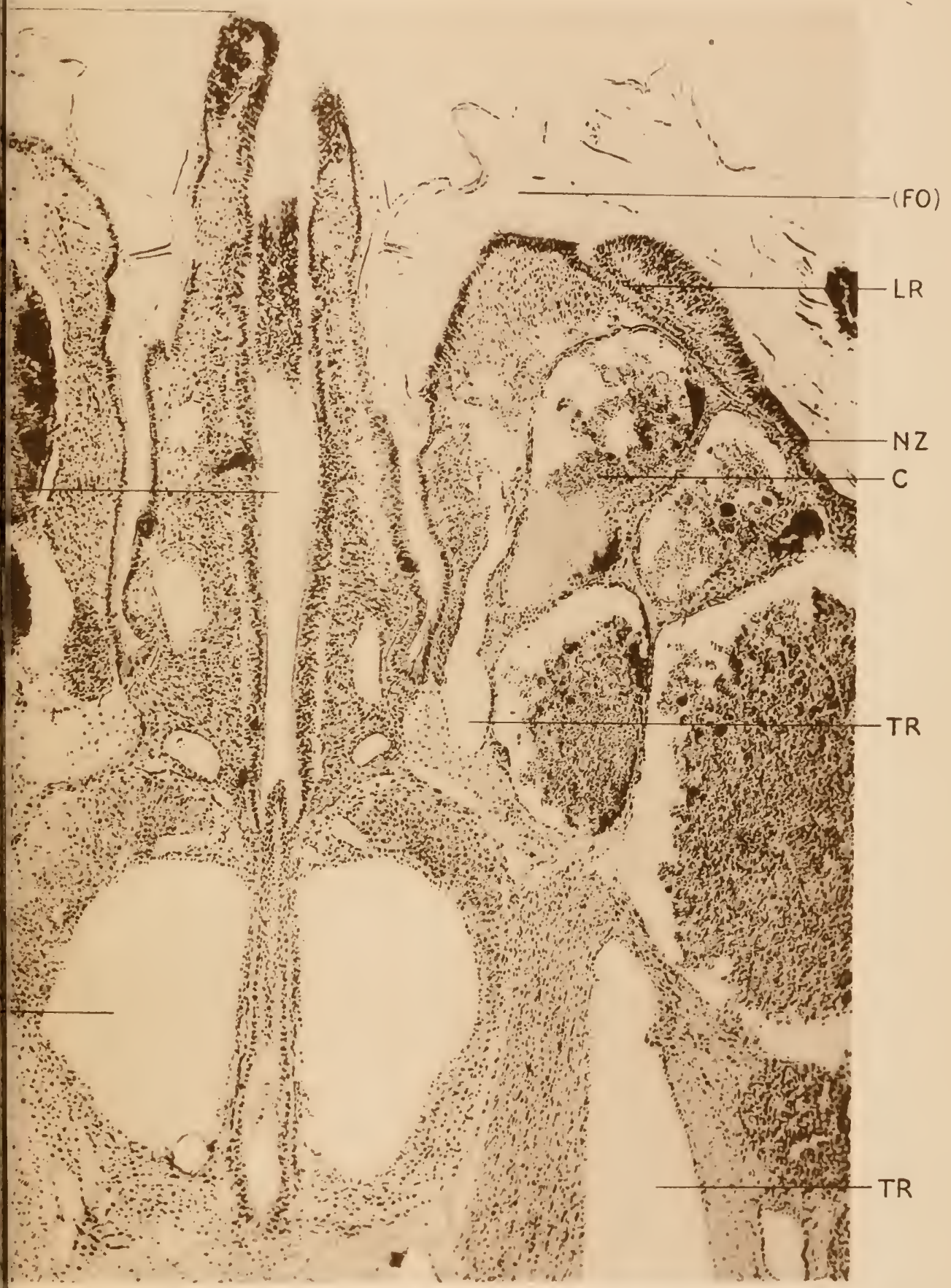

J. B. Obernetter, München, reprod. 


Zoolog. Jahrbuicher Suppl. 14.
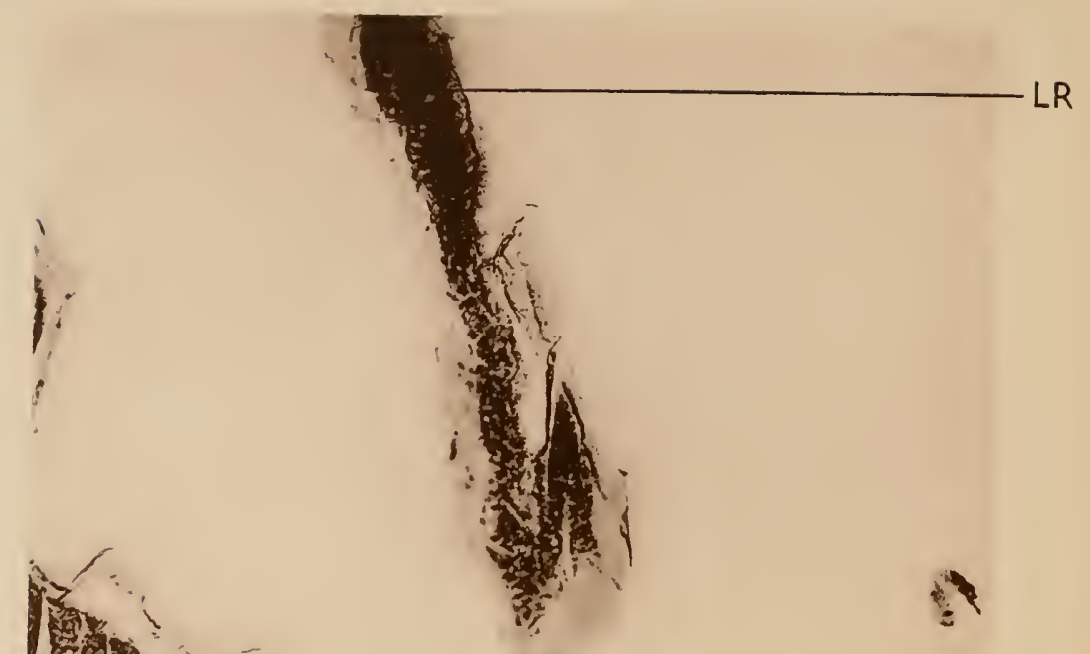


$\begin{array}{lll}\text { (FO) } & 40 a & \text { Taf. } 33 .\end{array}$

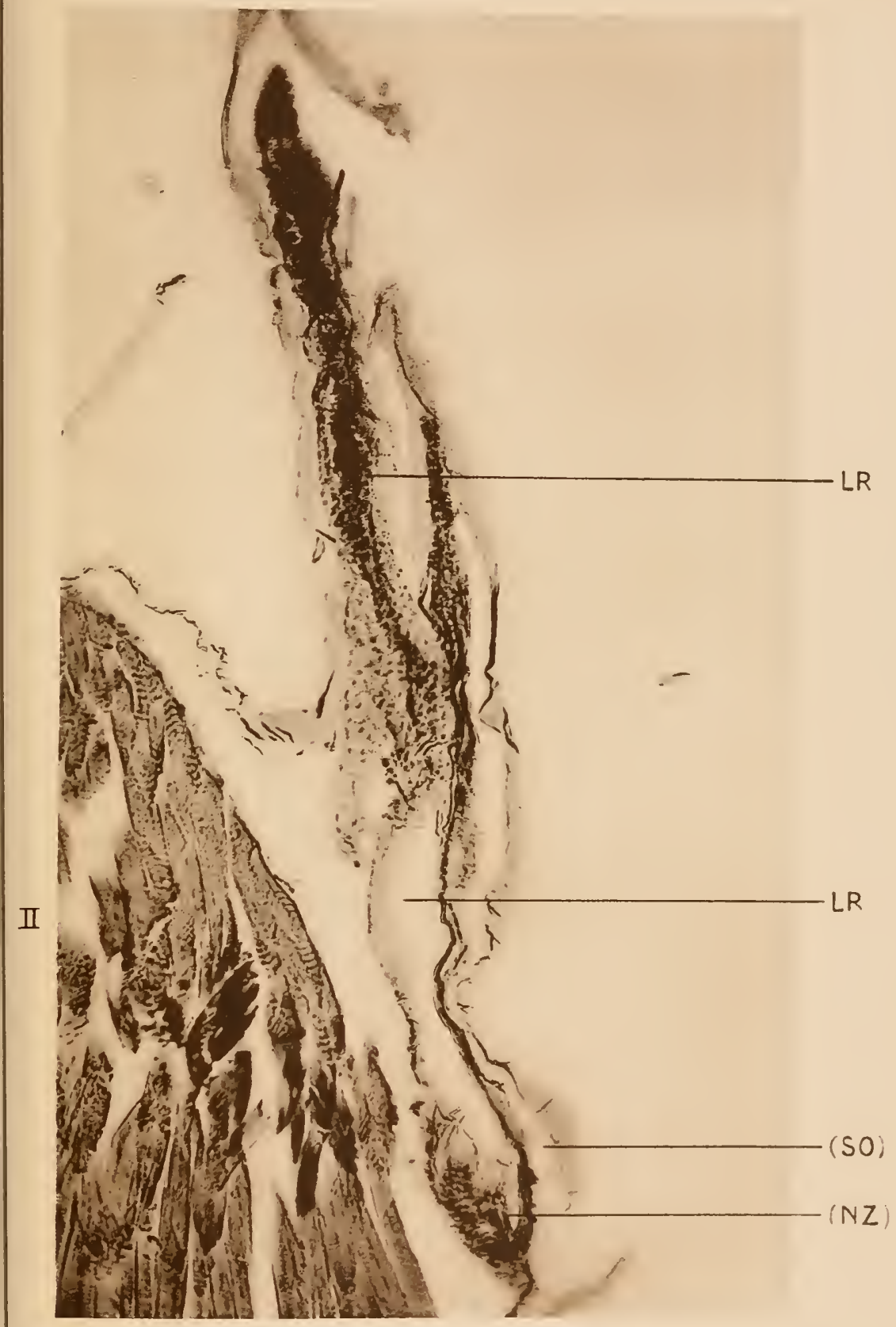

II

J. B. Obernetter, München, reprod 


Zoolog. Jahrbücher Suppl. 14.

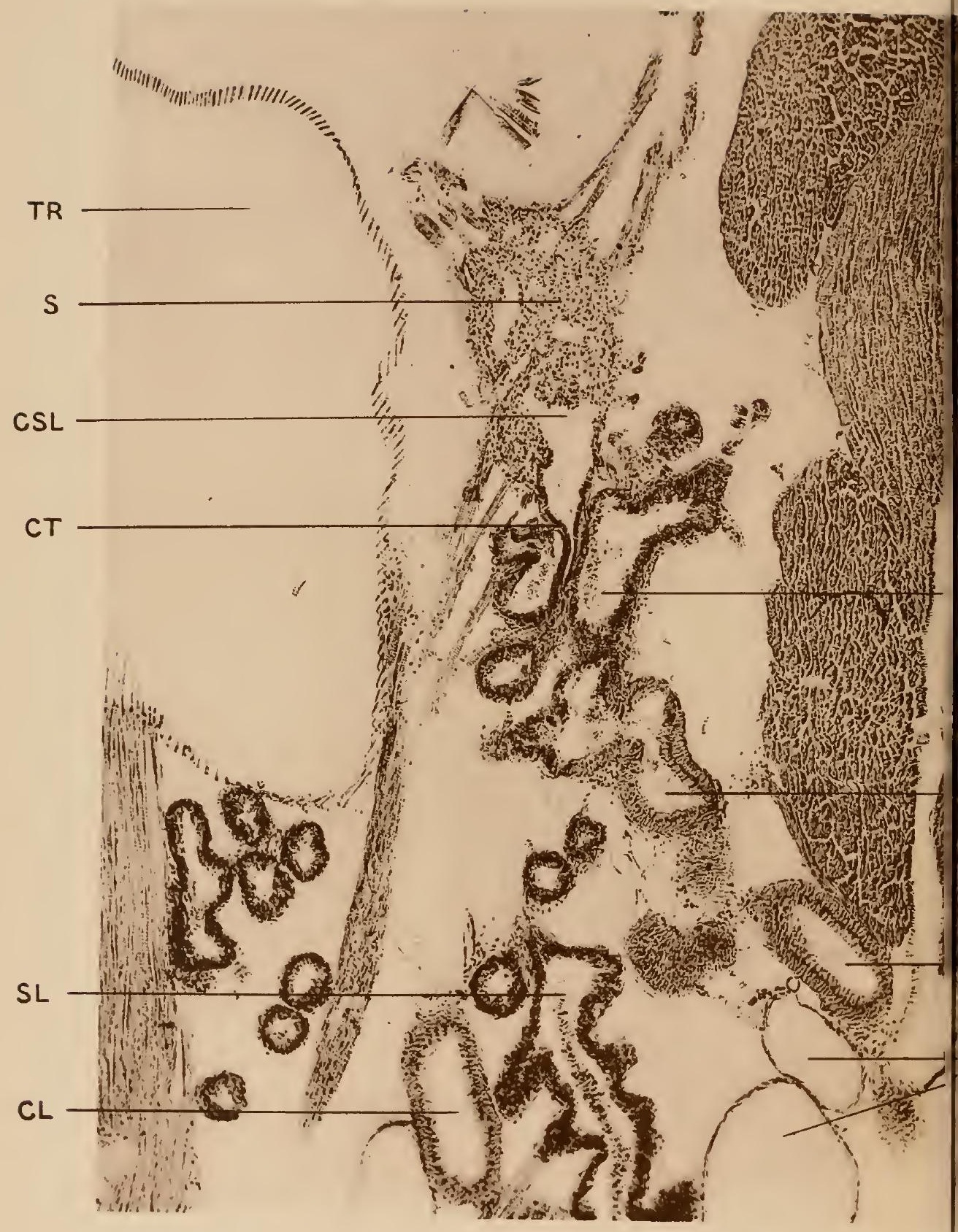

Buxton.

Verlag von $G$ 
Taf. 34.

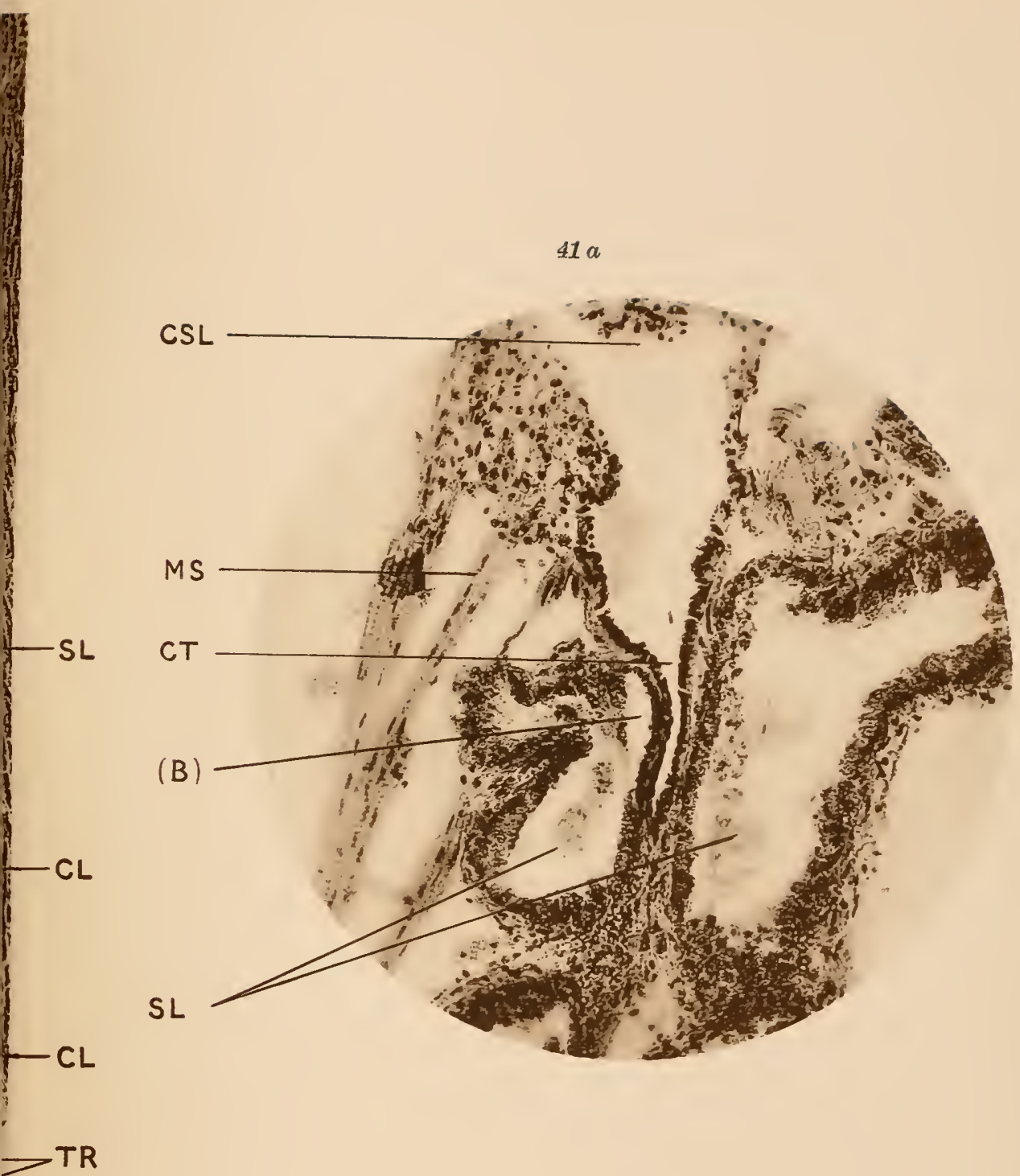

J. B. Obernetter, Műnchen, reprod. 


Zoolog. Jahrbücher Suppl. 14.

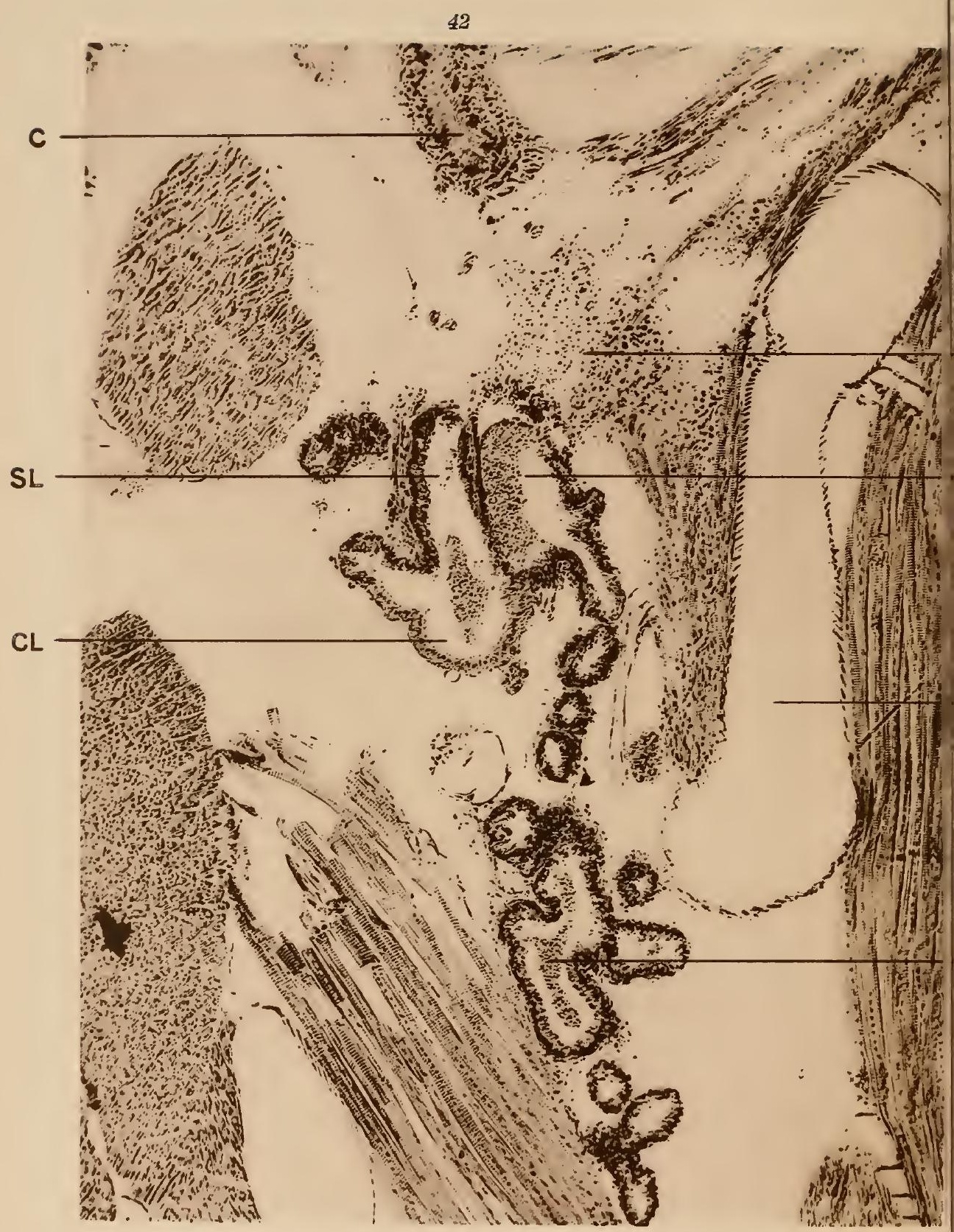

Buxton

Verlag von Gust 
Taf. 35.

$42 a$

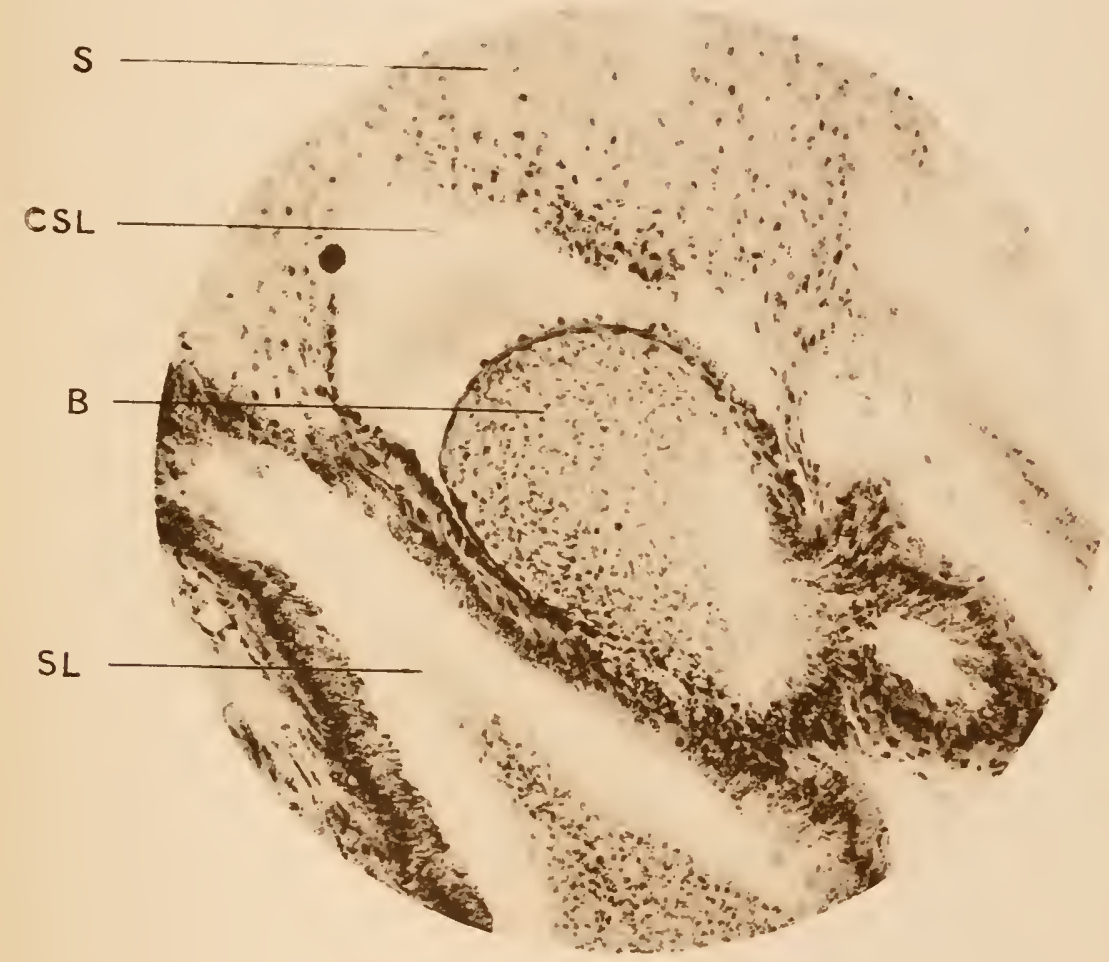

J. B. Obernetter, München, reprod. 




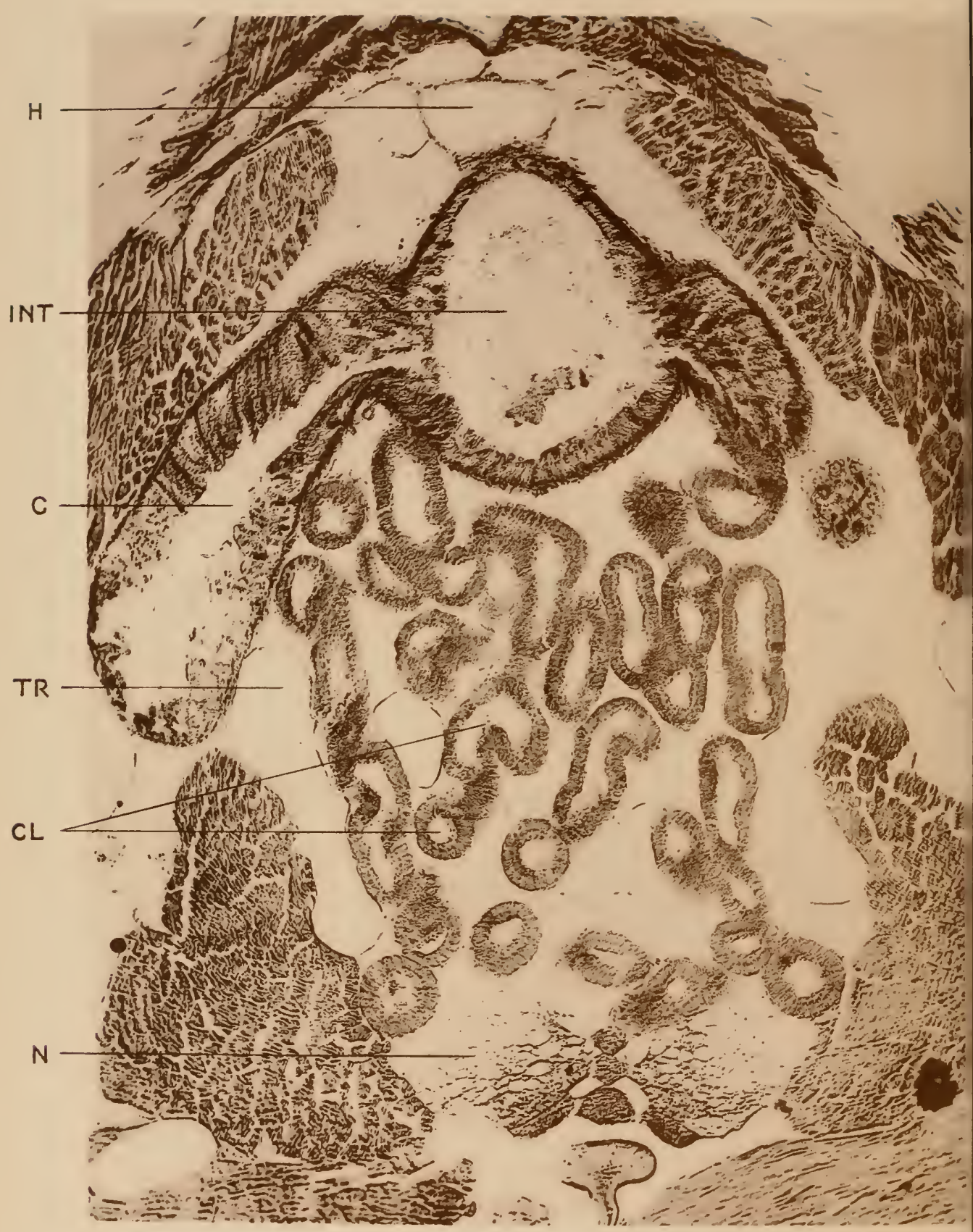

Buxton, 


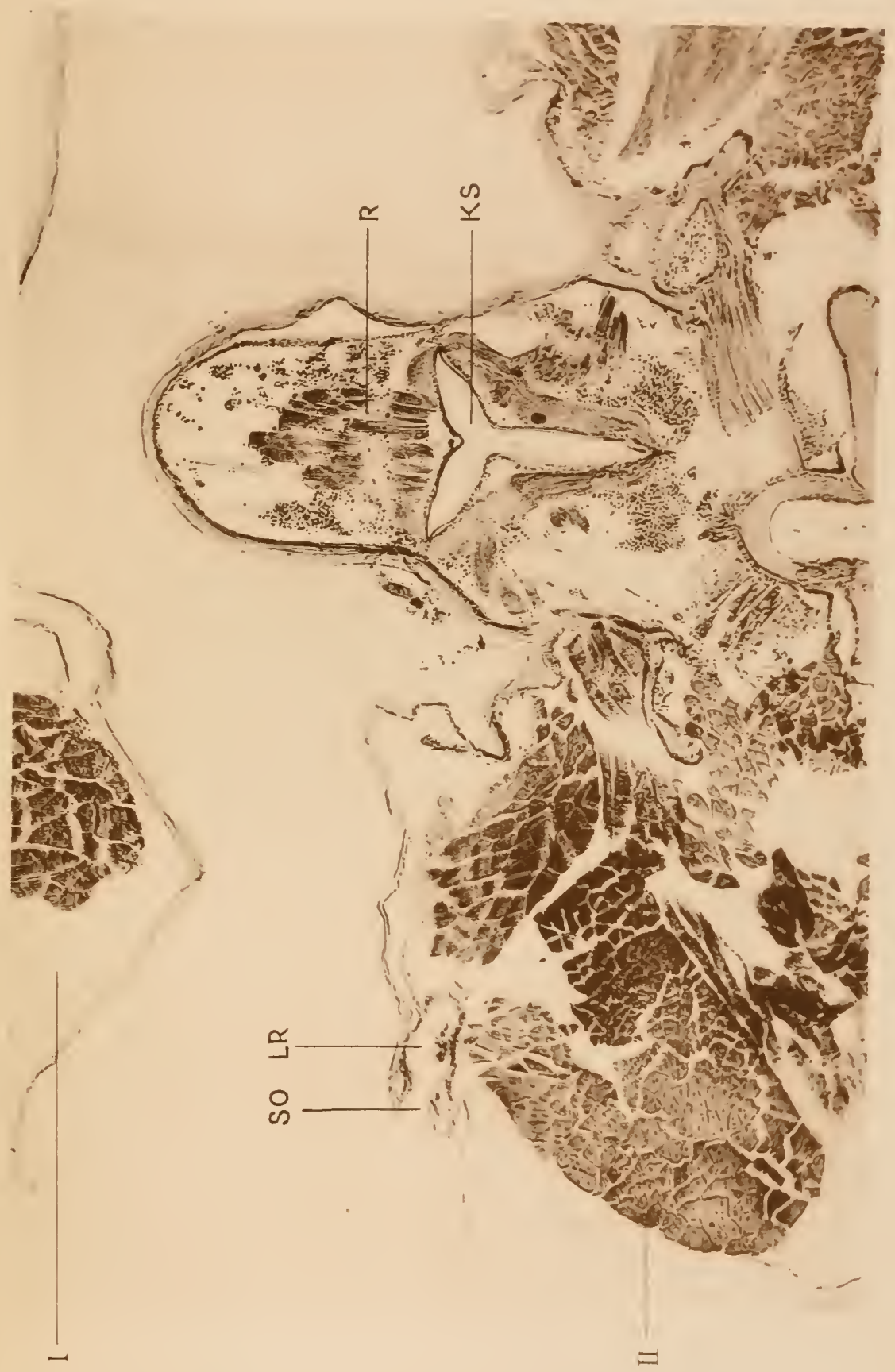

J. B. Obernetter, München, reprod. 


Zoolog. Jahrbücher Suppl. 14.

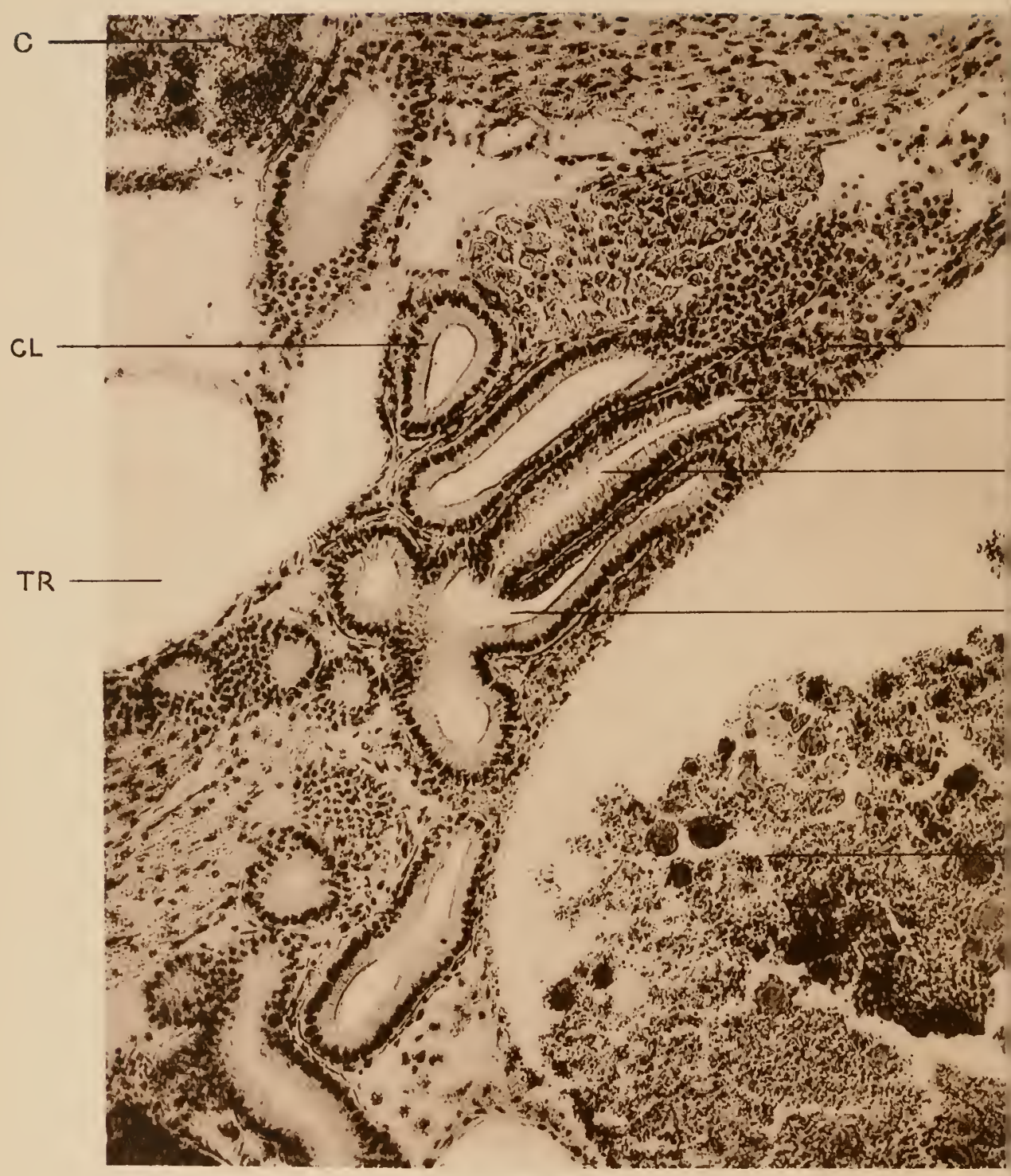

Buxton. 
CSL

CT

$S L$

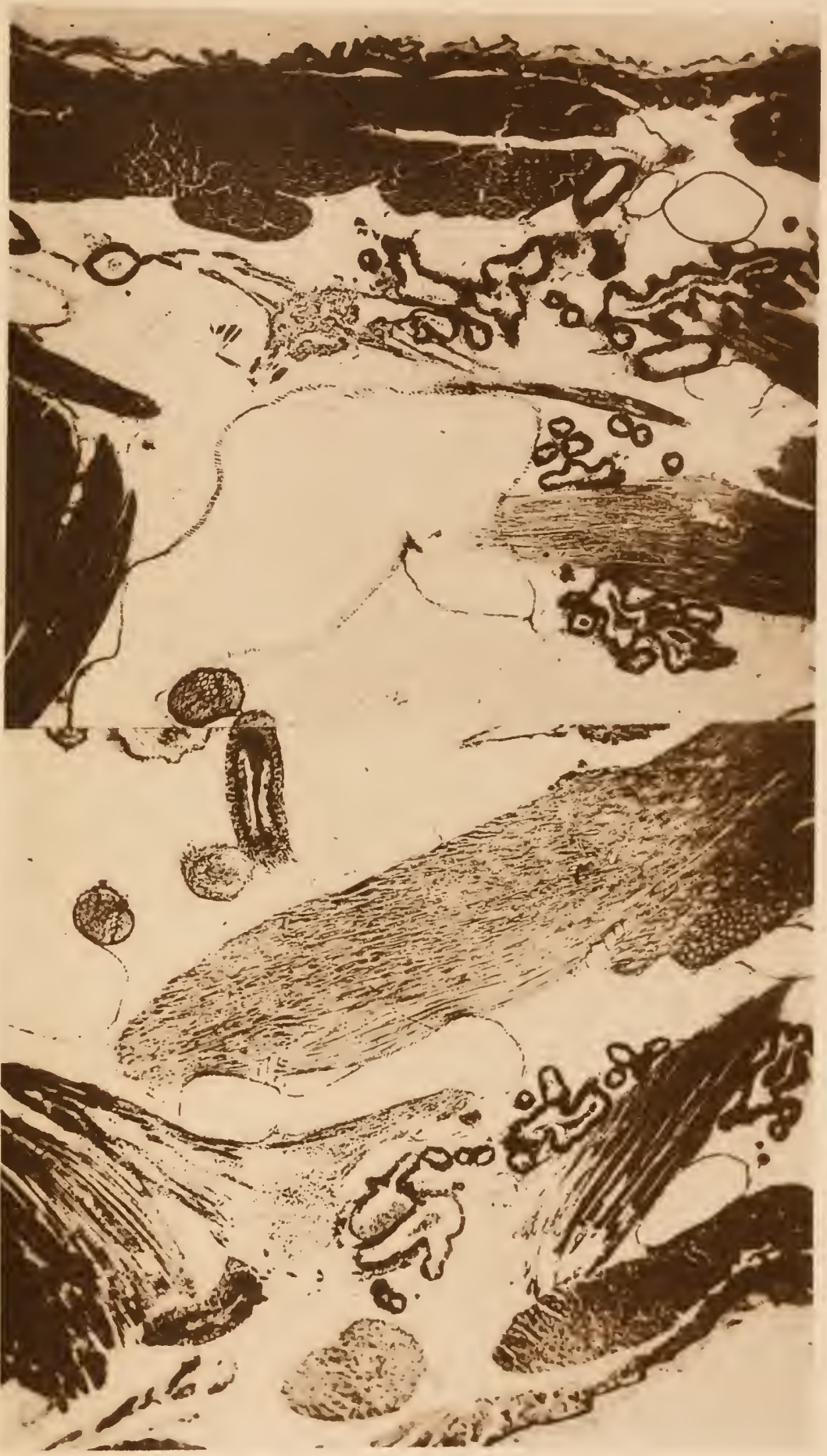

J. B. Obernetter, München, reprod 


Zoolog. Jahrbücher Suppl. 14.

47

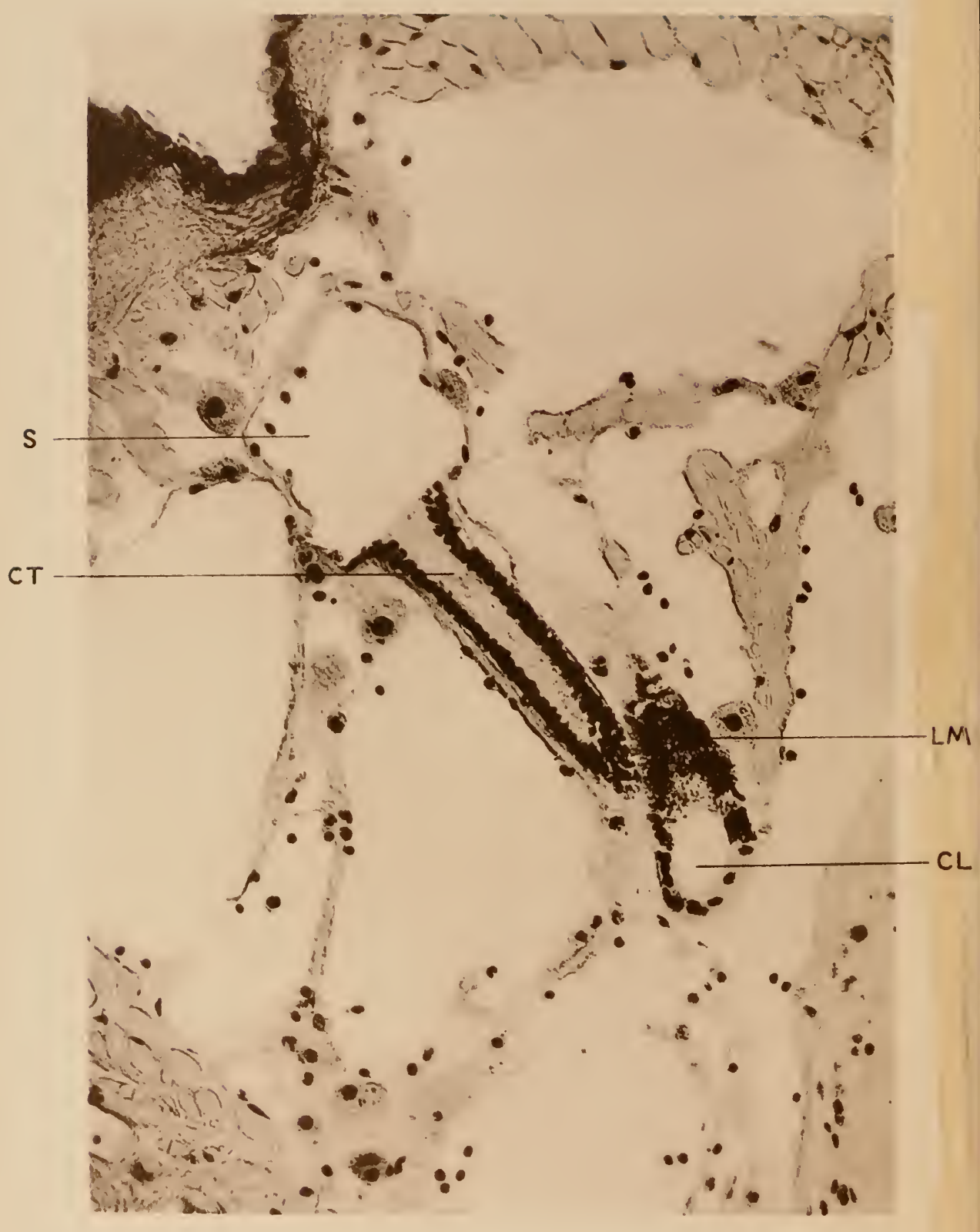

Buxton.

Verlag von Gu 
Taf. 38.

$47 a$

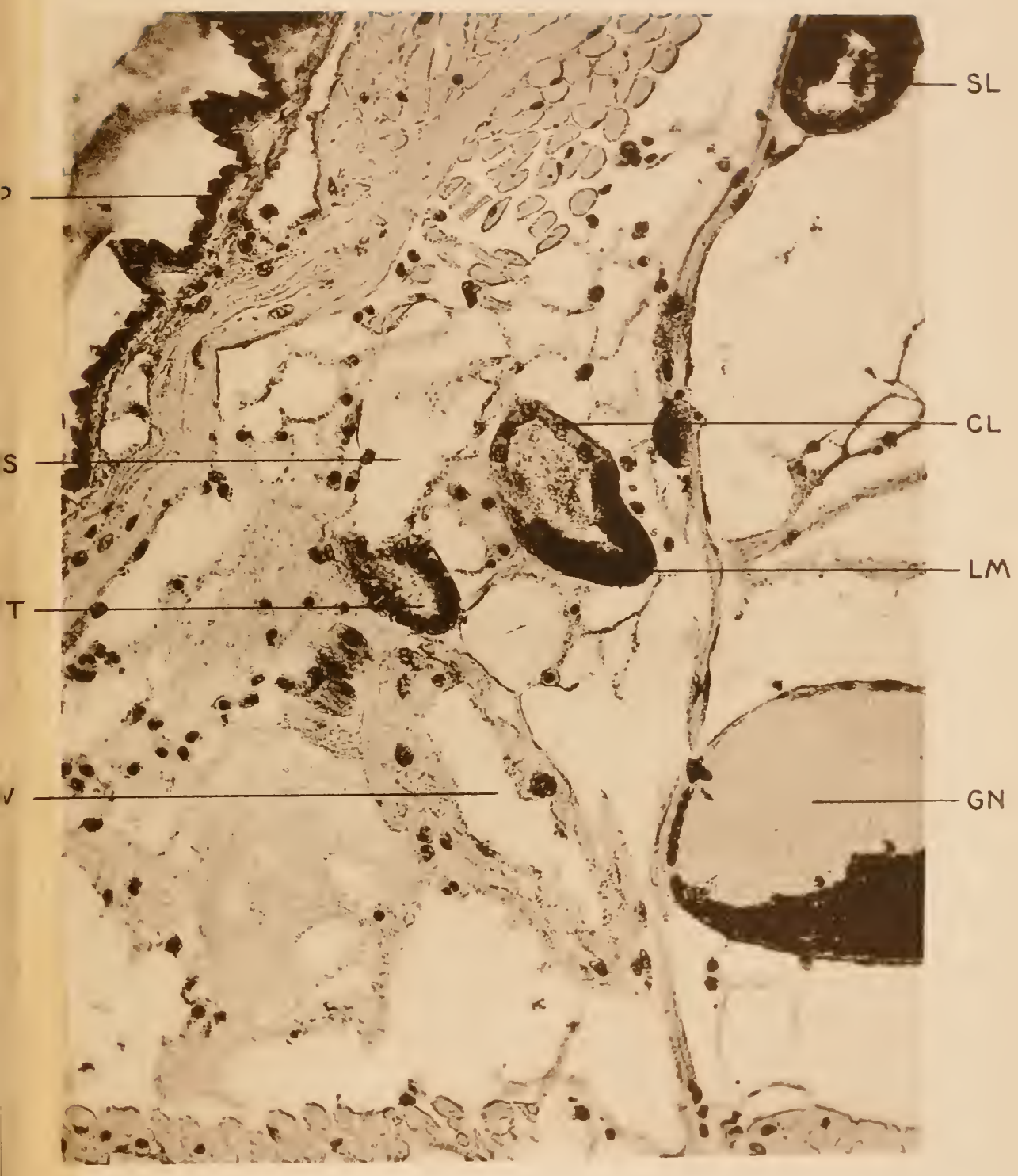

J. B. Obernetter, München, reprod.

v Fischer in Jena. 


Zoolog. Jahrbiicher Suppl. 14.
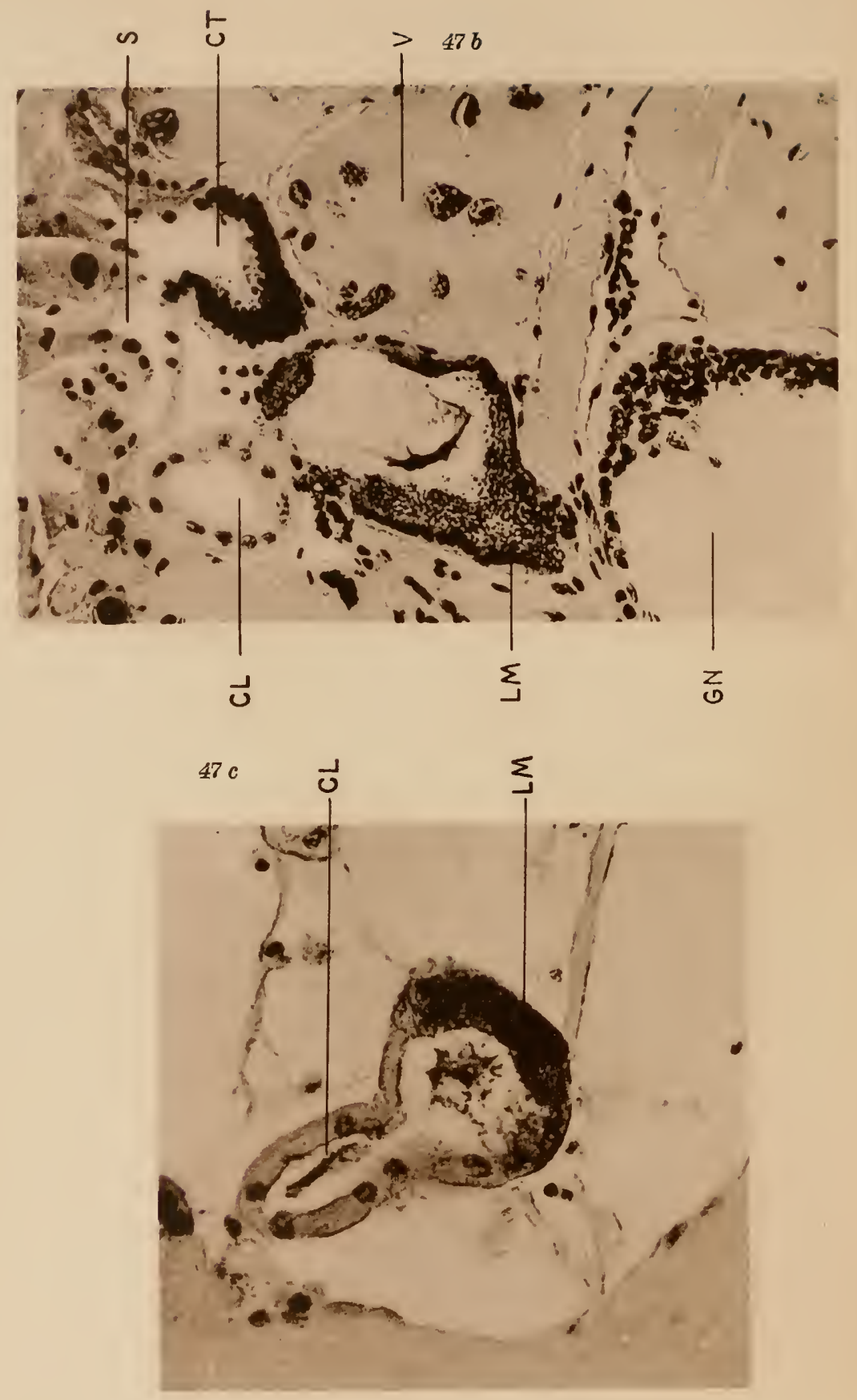

Buxton. 


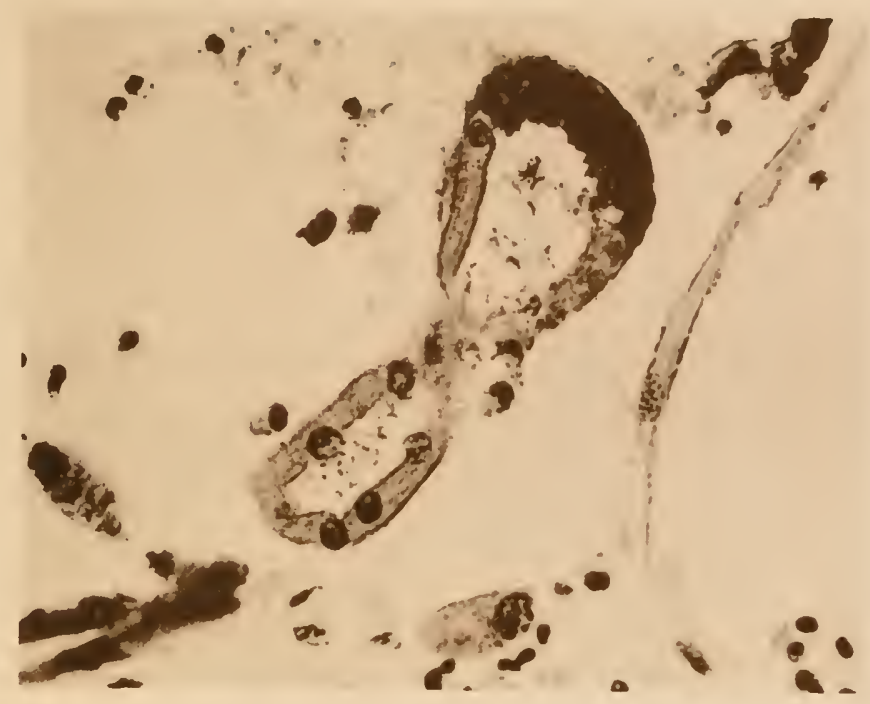

48

DSL

CT

S

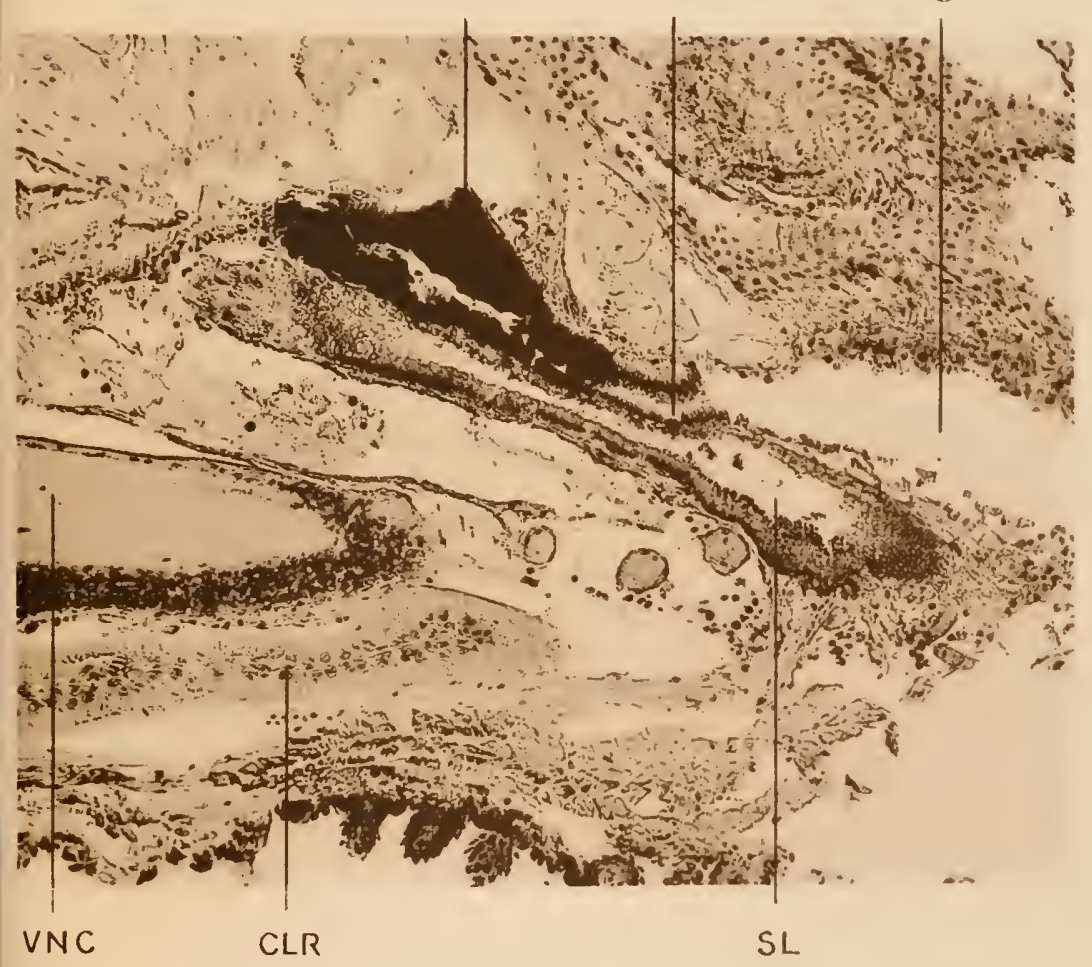

J. B. Obernetter, München, reprod. 




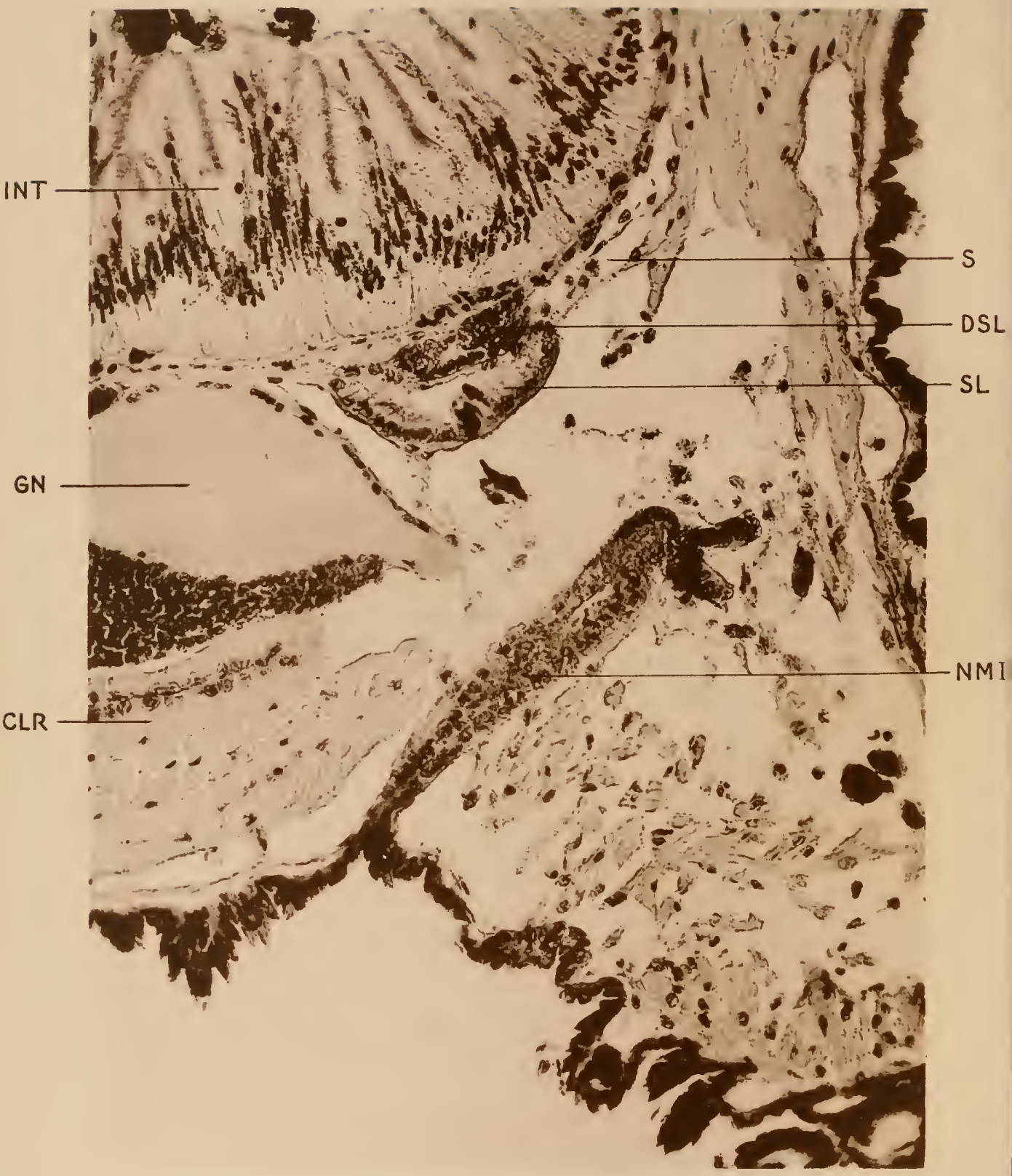

Buxton. 


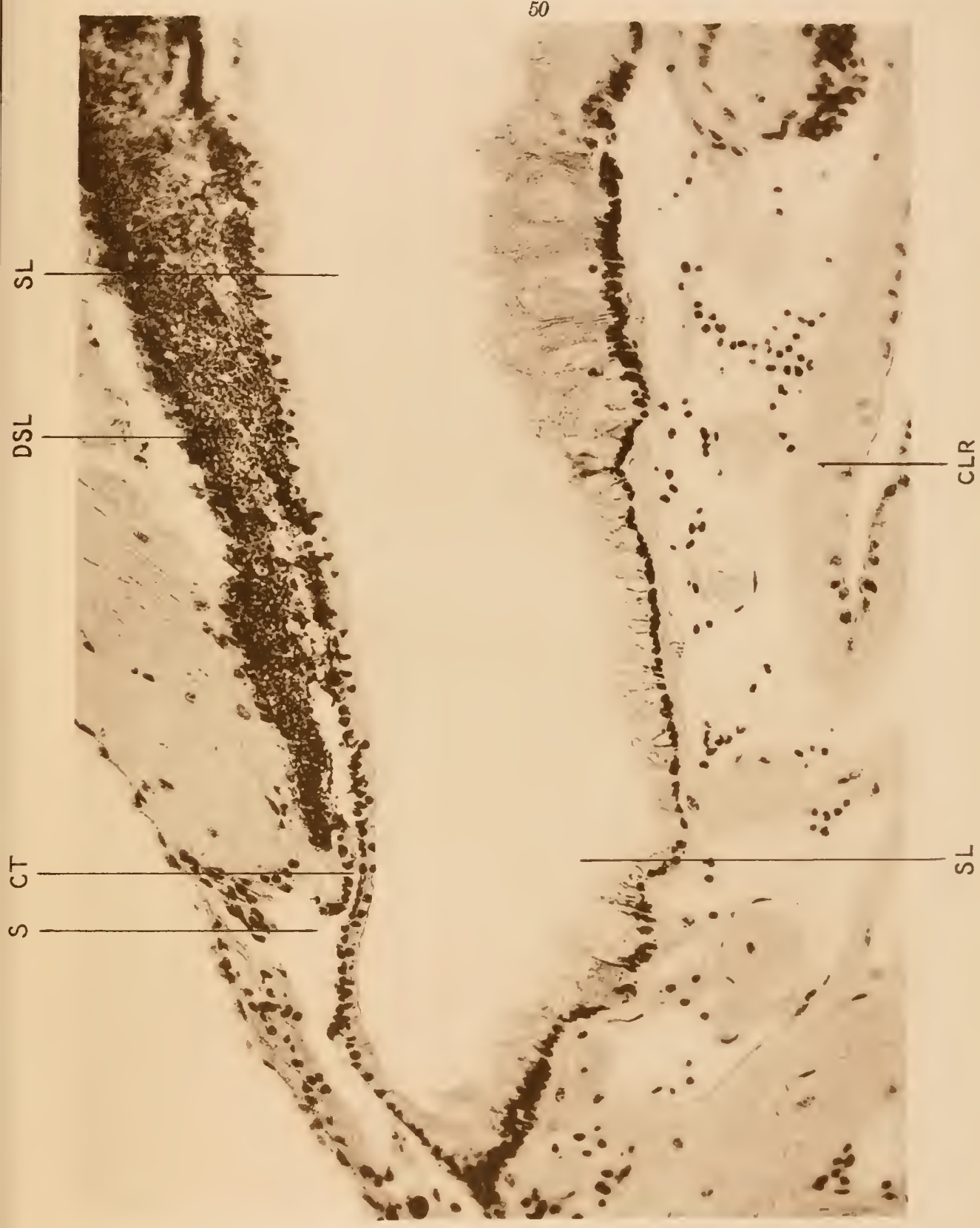

J. B. Obernetter, München, reprod.

Fischer in Jena. 


Zoolog. Jahrbücher Suppl. 14.

$50 a$

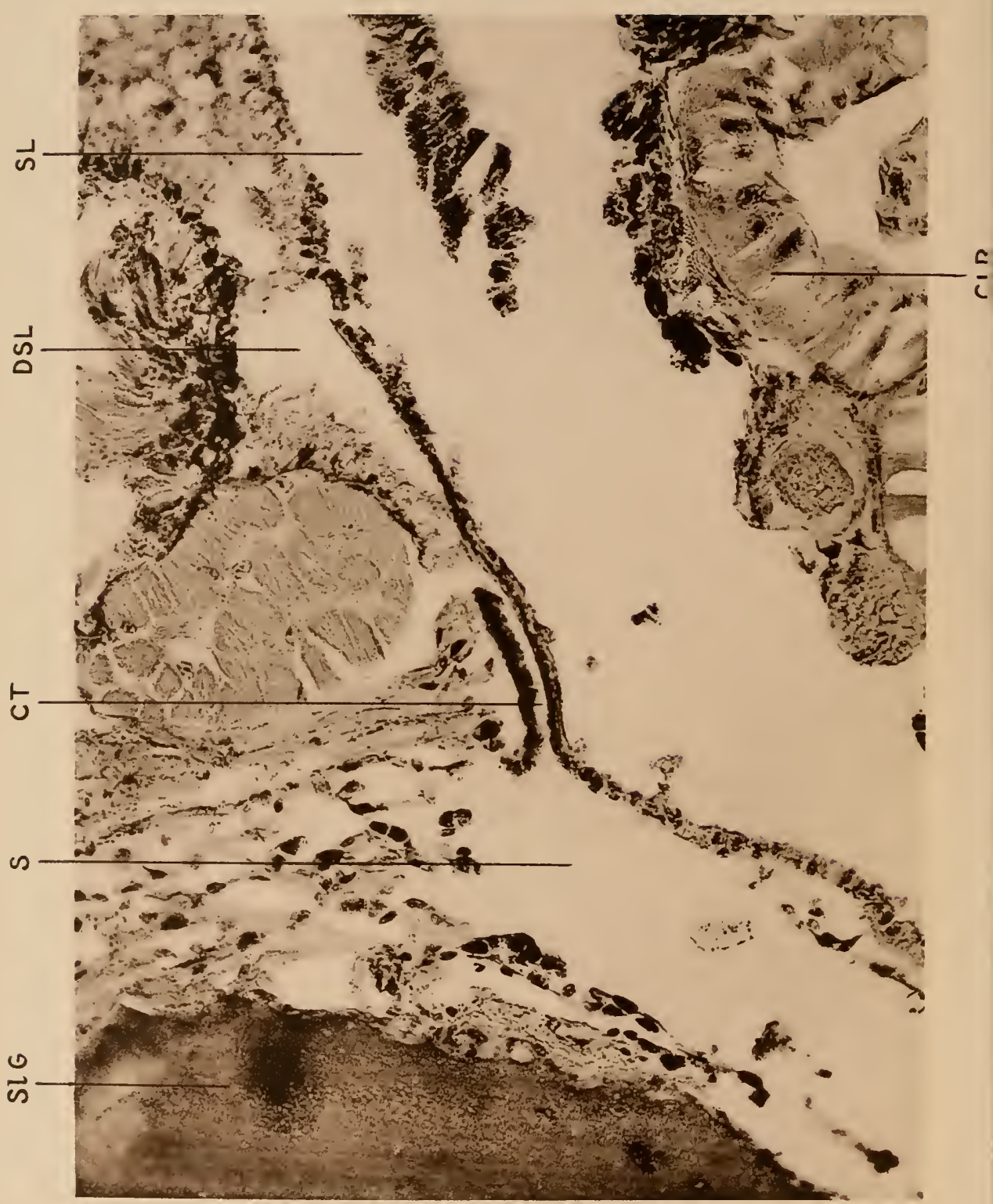

Buxtor.

Verlag von Gustav 
Taf. 41.

$50 b$

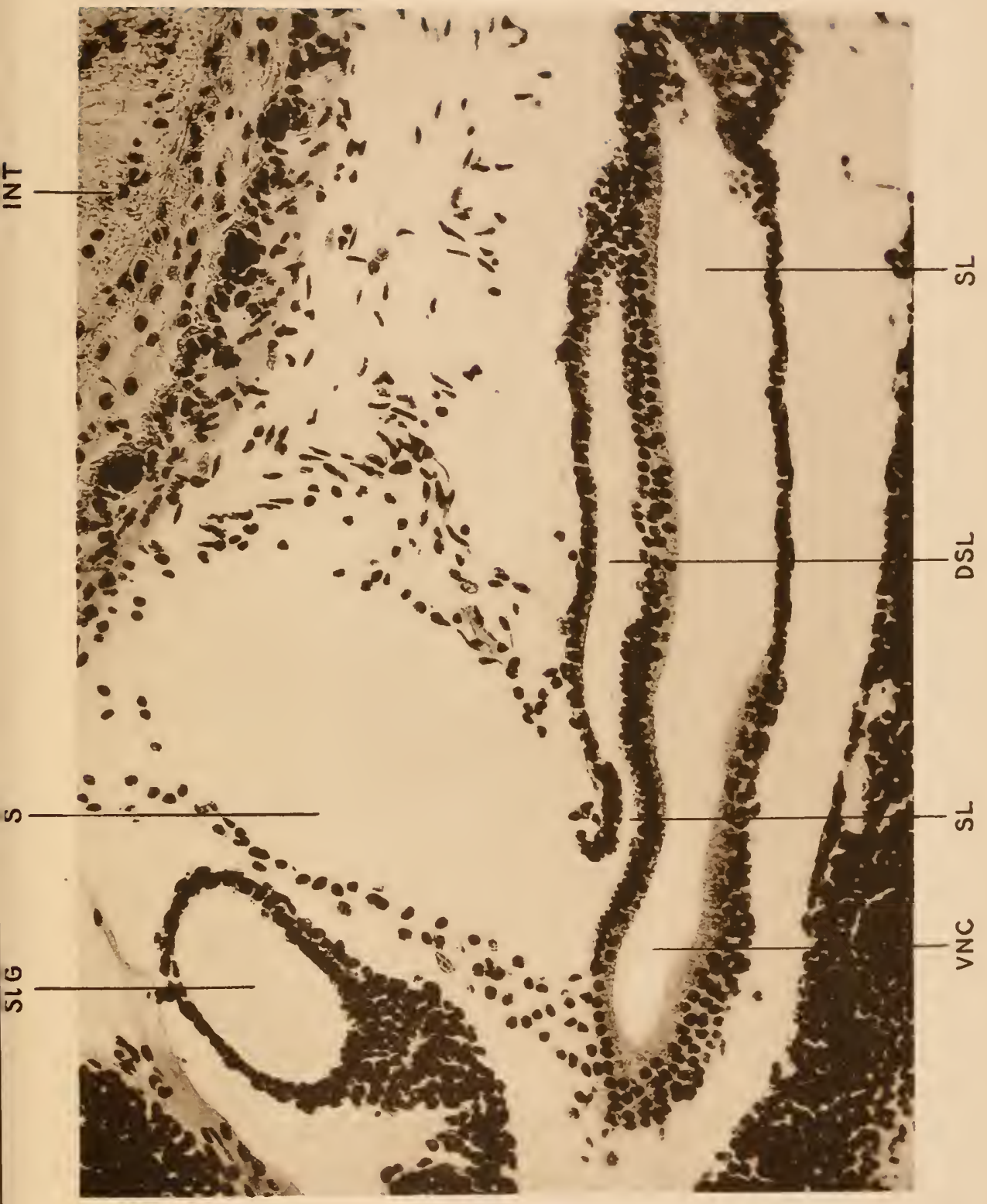

J. B. Obernetter, München, reprod.

scher in Jena. 

Zoolog. Jahrbücher Suppl. 14.

51

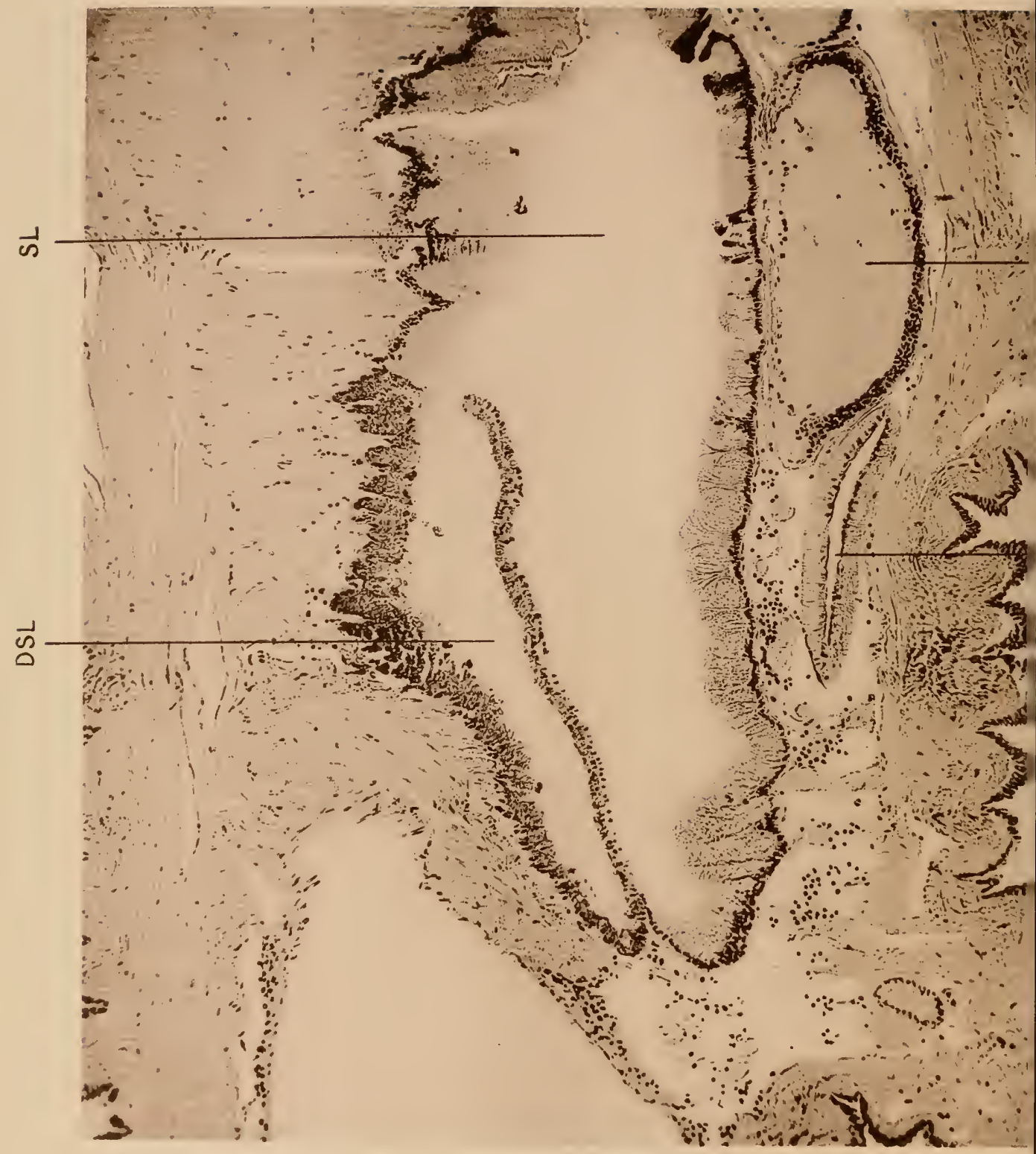

Buxton.

Verlag von Gustav 1 
Taf. 42.

62

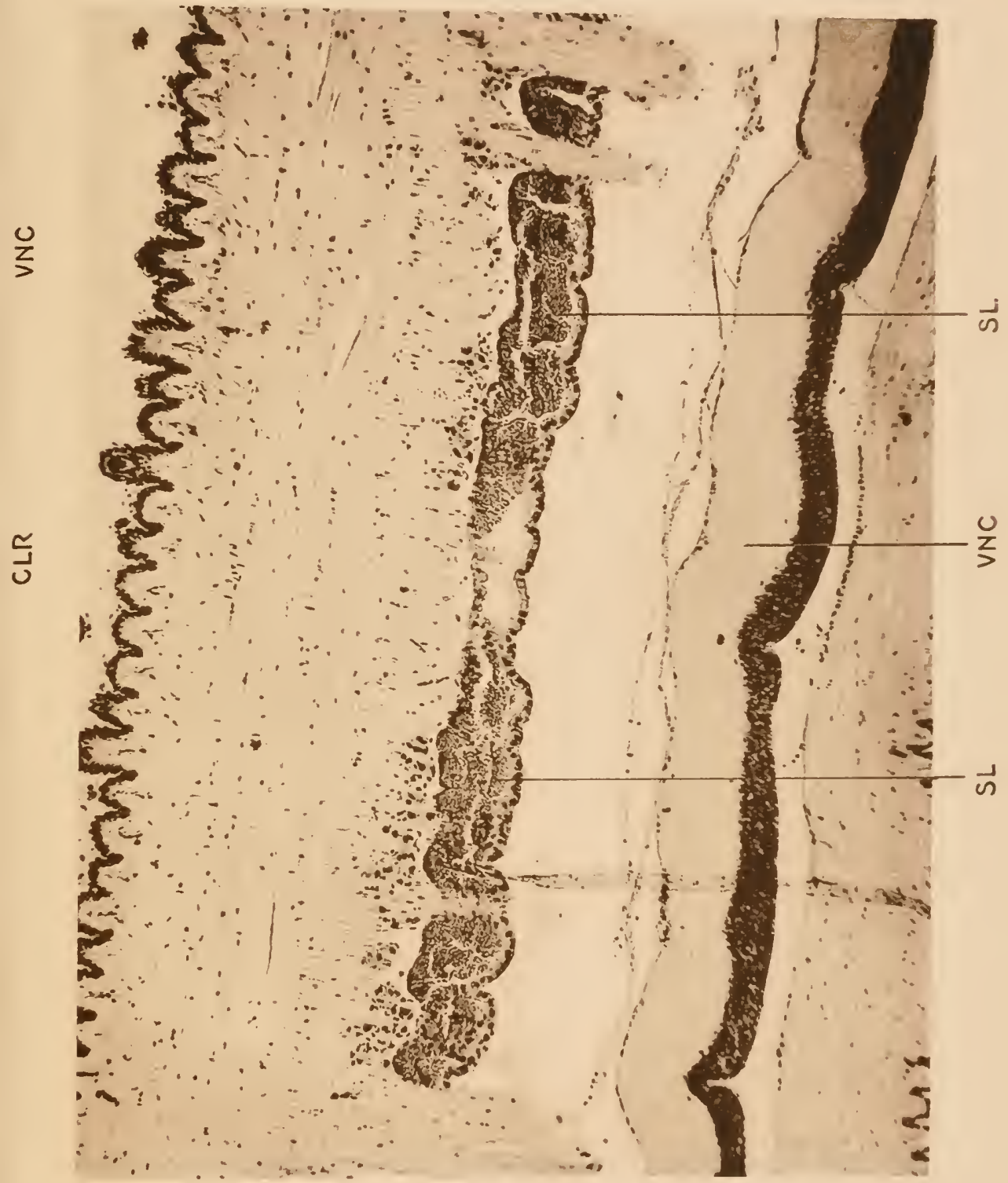

J. B. Obernetter, München, reprod.

her in Jena. 




\section{Zoolog. Jahrbiücher Suppl. 14.}

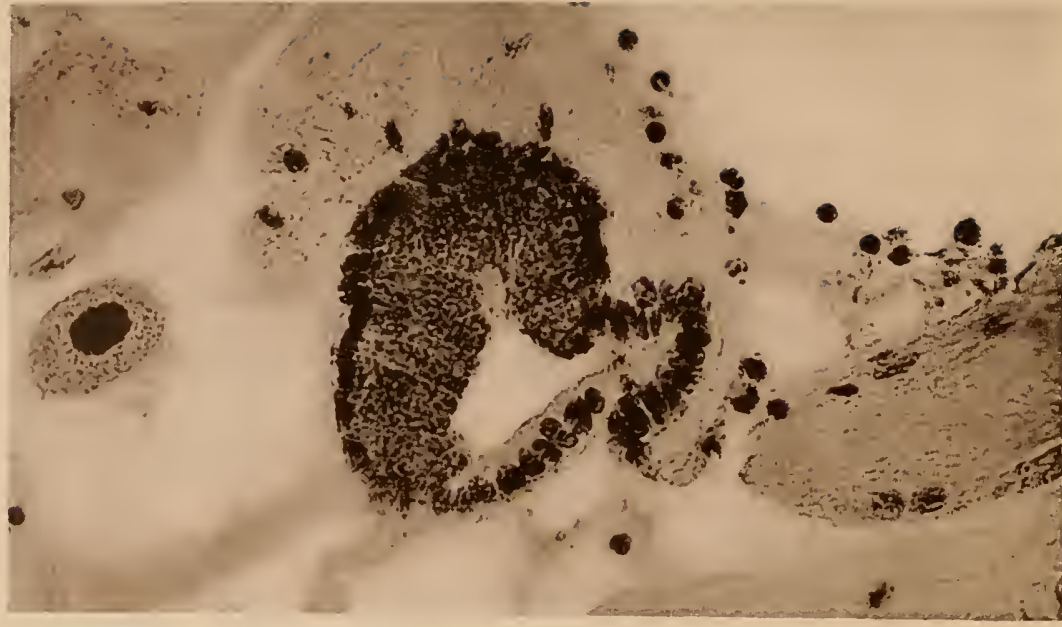

\section{$63 \quad$ GN $N$}

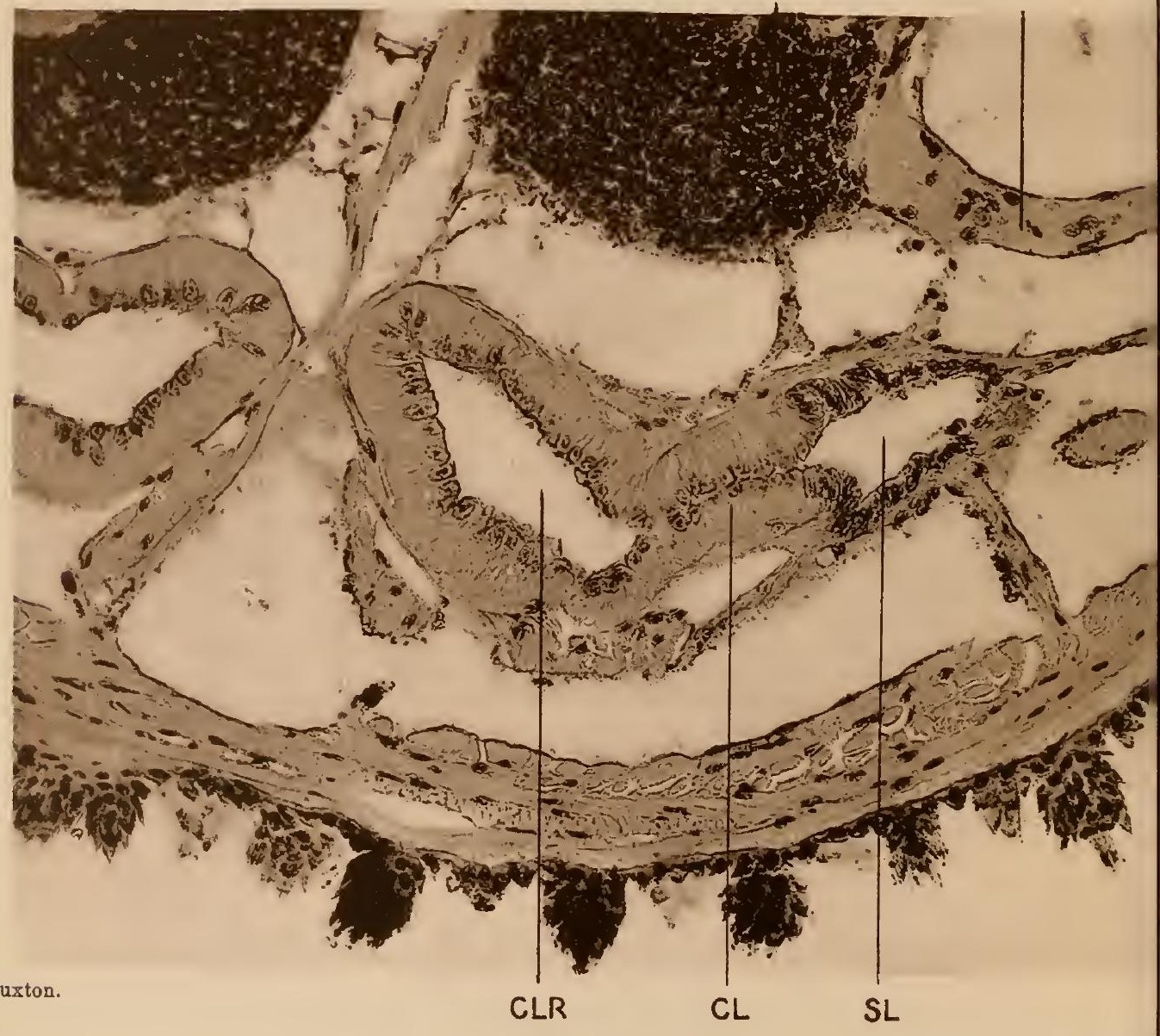

Verlag von Gustav ] 

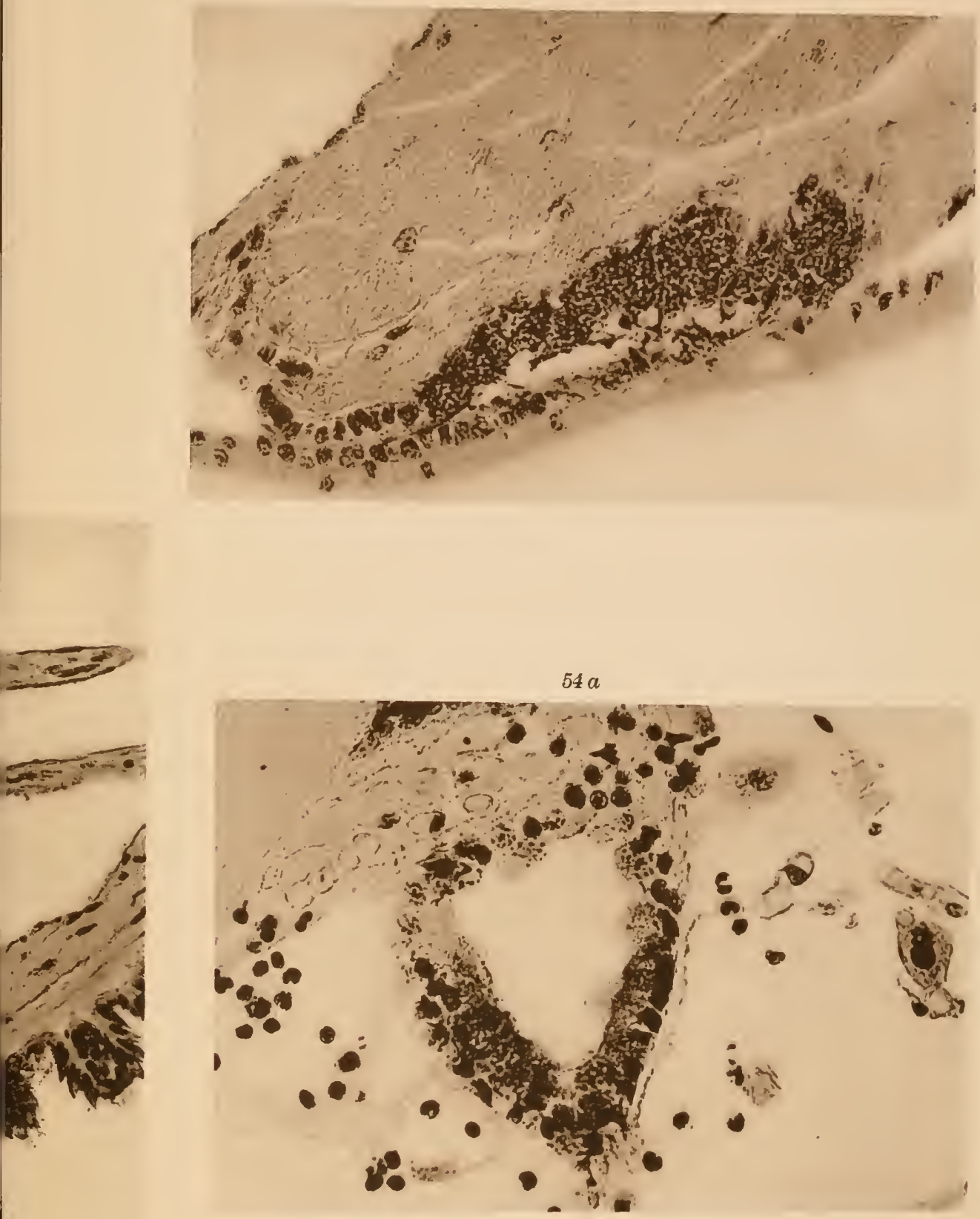

J. B. Obernetter, München, reprod.

Ther in Jena. 

(s) Festschrift zum achtzigsten Geburtstage des Herru Geheimen Regierungsrats Prof. Dr. KarI Möbius in Berlin. Mit 20 Tafeln und 20 Textabbild. 1905. 654 S. gr. $8^{\circ}$. Preis: 36 Mark.

Inhalt: Karl August Möbius. Von Fr. Dahl. - Koreanisohe Süsswasser-Mollusken. Von Ed. von Maltens. - Revision von Hellers Asoldien-Typon ans dem Museum Godefroy. Von W. Michaelsen. - Beiträge zur Kenntnis der Molluskenfauna der Magalhaen-Provinz. Von Hermann Strebel. - Dio geographischo Vorbreitung der Scolopendriden. Von Karl Kraepelin. - Ueber die Entwioklnngsstufen der Steinlänfer, Lithobilden, and Beiträge zar Kenntnis der Chilopoden. Von Karl W. Verboeff. - Tierreicho nnd Pflanzenretoho des Landes. Von F. Höck. - Zur Systematik der koloniebildenden Radiolarien. Voll K. Brandt. - Die Appendionlarien des arktischen und unarktischen Geblets, ihre Beziehnngen zneinander and za den Arten des Gebjets der warmen Ströme. Von H. Lobmann. - Asciden von Mauritins. Von R. Hartmeyer. - Dio zoogeographischen Beziehungen Südamerikas, betrachtet an den klassen der Reptilien, Amphibien und Fische. Von G. Pfeffer. - Ueber einige stieläugige Krebse von Messina. Vou Joh. Thiele. - Ueber die Lebensweise und die geographische Verbreitung der coprophagen Lamellicornier. Von H. J. KoJbe. - Beitrag zar Kenntnis der Metamorphos gofiügelter Heteropteren. Von Th. Kuhlgatz. - Uober dio Bedentang des Begrifis der Biocönose für den biologischen Schulunterricht. Von Karl Matzdorff. - Betrachtungen über die Architektonik der Tiere. Von J. W. Spengel.

1) Studien über die skandiuavisehen und arktisehen Maldaniden, nebst Zusammenstellung der ïbrigen bisher bekannten Arten dieser Familie. Von Irar Arwidsson, Upsala. Mit 12 Tafeln. 1907. Preis: 15 Mark.

2) Triehopterologisehe Untersuchungeu. Nr.2. Ueber die postembryonale Entwicklung der Trichopteren-Larven. Von A. J. Siltala, Helsingfors. Mit 5 Tafeln und 20 Abbildungen im Text. $1907 . \quad$ Preis: 16 Mark.

Nr. 1 der Trichopterolog. Untersuchungen („Über den Laich der Trichopteren") ist erschienen in "Acta Societatis pro Fauna et Flora Fennica vol. 28, Nr. 4 [1906]".

1) Die Cestoden der Vögel. Von 0. Fuhruann, Neuchâtel. 1908. Preis : 8 Mark.

, 2) Studien zur Geschichte der Sehweinerassen, insbesondere derjenigen Schwedeus. Von Adolf Pira, Stockholm. Mit 52 Abbildungen im Text. 1c09.

Preis: 10 Mark.

, 3) Synopsis der rezenten Schildkröten, mit Berïcksichtigung der in historischer Zeit ausgestorbenen Arten. Von F. Siebenrock, Kustos am k. k. Naturhistor. Hofmuseum in Wien. 1809.

Preis: 6 Mark.

, †) Tabanideu Brasiliens und einiger Nachbarstaaten. Von Ad. Lutz, Direktor des Staatl. Bakteriologischen Instituts in St. Paulo (Brasilien). Mit 3 farbigen Tafeln. 1909.

Preis : 14 Mark.

11) Ergebnisse einer Forschungsreise nach Westindien in Jahre

1907 von Prof. W. Kuikenthal und Dr. R. Hartmeyer.

Erster Teil. (S. 1-104.) Mit 8 Tafeln und 8 Abbildg. im Text. 1908. Preis : 15 Mark. Inhalt: Einleitung and Reisebericht. Von W. Kükenthal. (S. 1-11.) - Die Oligochaeten Westindiens. Von W. Michaelsen. (S. 12-32.) Mit 1 Tafel. - Beitrag zur Bienen. fanna der tleinen Antillen und der Berinudas. Von H. Friese. (S. 33-40.) - Zur Kenntnis der Alcyonarien-Gattung Tolesto LMX. Von H. Lackmann. (S. 11-104.) Mit 7 Tafeln und $8 \mathrm{Ab}$. bildungen im Text.

Zweiter Teil. (S. 105-342.) Mit 11 Tafeln, 52 Abbildungen im Text und 1 Karte. 1910. Preis: 24 Mark.

Inhalt: Blattidae. Von R. Shelford. (S. 105-108.) - Molluskenfanna Westindiens. Von Job. Thiele. (S. 109-132.) Mit 1 Tafel. - Westindische Chätognathon. Von $R$ udolf v. Ritter-Zábony. (S. 133-143.) Mit 1 Tafel. - Wostindisohe Seelgel and Seosterne. Von L. Döderlein n. R. Hartmeyer. (S. 144-156.) - Stadien an westindischen Actinien. Von Ferdinand Pax. (S. 157-330.) Mit 9 Tafeln, 46 Abbildungen im Text nnd 1 Karte. - Westindisohe Holothurion. Von C. P. Sluiter. (S. 331-342.) Mit 6 Abbildungen im Text.

Dritter Teil. (S. 343-432.) Mit 2 Tafeln und 63 Abbildungen im Text. 1913. Preis: 9 Mark.

Inhalt: Die Appendionlarien. Von H. Lobmann. (S. 313-350.) Mit 2 Abbildungen im Text. - Ophinres. Von R. Koehler. (S. 351-380.) Mit 2 Tafeln. - Westindischo Deoapoden. Vou C. Zimmer. (S. 381-412.) Mit 57 Abbildungen im Text. - Ueber westindische Medusen. Von E. Vanhöffen. (S. 413-432.) Mit 4 Abbildungen im Text. 
$(12,1)$ Über die Geseliehte der Tierwelt vou Ceylon. Von Fritz Sarasin. Mit 6 Karten. 1910.

Preis: 7 Mark.

$(12,2)$ Cassidem und Cryptocephaliden Paraguays, ihre Entwicklungsstadien und Schutzvorrichtungen. Von Carl Fiebig, San Bernardino (Paraguay). Mit 6 Tafeln. 1910.

Preis: 15 Mark.

$(12,3)$ Festschrift zum 60. Geburtstage des Herru Gel. Regierungsrates Prof. Dr. Max Braun in Königsberg. Mit 13 Tafeln und $183 \mathrm{Ab}$ bildungen im Text. 1910.

Preis: 36 Mark.

Inhalt: Die Echinostomiden der Vögel. Von Eugen Dietz. Mit 6 Tafeln und 78 Abbildungen im Text. - Zur Kenntnls gehänsetragender Lepldopterenlarven. Von Alfous Dampf. Mit 54 Abbildungen im Text. - Mesopsylla onota n. g. n. sp. Von Alfons Dampf. Mit $31 \mathrm{Ab}$. bildungen im Text. - Der Zng des wolssen Storohes (Cioonia oloonla). Yon J. Thienemann. Mit 3 Tafeln. - Cystotänien südamerikanisober Follden. Von M. Lühe. Mit 2 Tafeln und $8 \mathrm{Ab}-$ bildungen im Text. - Weitere Beiträge znr Kenntols der Walhant. Von Arnold Japha. Mit 1 Tafel. - Znr Kenntals der Mundarüsen einiger Annren. Voll $L$ udwig Cohn. Mit 9 Abbildungen im Text. - Beiträgeznr Kenntais der Dipteren-Grnppe Heleinae. Von P. Spe iser. Mit 1 Tafel. Supplement 13 siebe "Fauna Chilensis. Bd. IV“.

$(14,1)$ Die bis jetzt bekannten Larven vou Thrombididae und Erythraeidae mit besonderer Berücksichtigung der für den Menscheu schädlichen Arten. Von Dr. A. C. Oudemans. Mit 57 Abbildungen im Text. 1912. Preis: 9 Mark.

$(\mathbf{1 4}, \mathbf{2})$ Coxal Glands of the Arachnids. By B. H. Buxton. With 43 Plates, a Frontispice and 7 Figures in the Text.

(15) Festschrift zum 60. Geburtstage des Herrn Geh. Regierungsrates Prof. Dr. J. W. Spengel. Heransgegeben vou A. Braner in Berlin, L. Döderlein in Straßburg, L. Dollo in Brïssel, H. Ludwig in Bonn, E. L. Mark, Harvard Univ., M. Weber in Amsterdam und A. Weismanu in Freiburg. 3 Bände. 1912 . Preis: 225 Mark.

I. Band. Arbeiten vorwiegend systematischen Inhalts. Mit 32 Tafeln und 59 Abbildungen im Text.

Preis: 75 Mark.

II. Band. Arbeiten vorwiegend anatomischen Inhalts. Mit 41 Tafeln und 212 Abbildungen im Text.

Preis: 100 Mank

11I. Band. Arbeiten vorwiegend aligemein zoologisehen und physiologischen Inhalts. Nit 18 Tafeln und 161 Abbildungen im Text.

Preis: 50 Mark.

Verzeichnis der einzclnen Arbeiten kostenírei.

Verlag von Gustav Fischer in Jena.

\section{Araneae, Acarina und Tardigrada.}

\section{Bearbeitet von \\ Prof. Dr. Friedr. Dahl, F. Koenike, Prof. Dr. A. Brauer, Berlin, \\ Bremen, Berlin.}

Mit 280 Abbildungen im Text.

(Süßwasser-Fauna Deutschlands. Hrsg. von Prof. Dr. A. Brauer-Berlin. Heft 12.) 1909. (191 S. Taschenformat.)

Preis: 4 Mark, geb. 4 Mark 50 Pf. G. Pätz'sclıe Buchưr. Lippert \& Co. G. m. b. H., Naumburg a. d. S. 




SMITHSONIAN INSTITUTION LIBRARIES

39088 0031667l? nhent OL 459.899 Coxal glands of the arachnids, 